\title{
SOFTWARE METRICS FOR PARALLEL PROGRAMS
}

\author{
By \\ IMTIAZ AHMAD \\ Bachelor of Science \\ University of the Punjab \\ Lahore, Pakistan \\ 1981
}
Submitted to the Faculty of the
Graduate College of the
Oklahoma State University in partial fulfillment of the requirements for the Degree of MASTER OF SCIENCE July, 1991




$$
\begin{aligned}
& \text { Thesi } \\
& \text { ogl } \\
& \text { cond }
\end{aligned}
$$




\section{SOFTWARE METRICS FOR \\ PARALLEL PROGRAMS}

Thesis Approved:

$\frac{M \cdot \operatorname{sannad} 3 a d 0 /-4}{\text { Thesis Adviser }}$
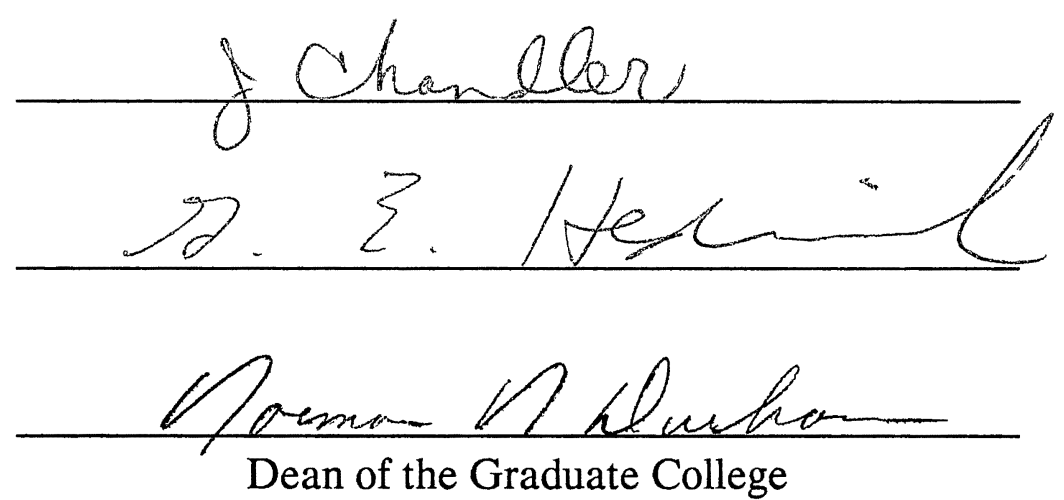


\section{ACKNOWLEDGEMENTS}

First I would like to thank my thesis advisor, Dr. Mansur H. Samadzadeh for his continuous guidance, dedication, and valuable instruction throughout my research work. Without his encouragement and motivation, completion of this thesis would not have been possible.

Special thanks are due to Dr. Keith A. Teague for providing access to the hardware necessary for this work, and to Dr. Gary B. Lamont for providing his compendium of parallel programs used as a testbed in this thesis. I also wish to thank Drs. P. Larry Claypool and William L. Woodall for helping me in the selection of statistical tests.

I would also like to thank Drs. John P. Chandler and George E. Hedrick for their suggestions and advice while serving on my thesis committee. In addition, I would like to thank my supervisor at the University Computer Center, Larry P. Watkins, for allowing me to follow a flexible work schedule during my thesis research.

Finally, I wish to thank my family. It was their continuous support that gave me the motivation and inspiration to complete my graduate studies. 


\section{TABLE OF CONTENTS}

Chapter

Page

I. INTRODUCTION $\ldots \ldots \ldots \ldots \ldots \ldots \ldots \ldots \ldots \ldots \ldots \ldots \ldots$

II. PARALLELISM: HISTORY AND HARDWARE $\ldots \ldots \ldots$

2.1 Definition of Parallel Processing $\ldots \ldots \ldots \ldots \ldots \ldots .5$

2.2 Types of Parallelism ..................... 5

2.3 Intel's iPSC Concurrent Supercomputers $\ldots \ldots \ldots \ldots .5$

III. SOFTWARE METRICS $\ldots \ldots \ldots \ldots \ldots \ldots \ldots \ldots \ldots$

3.1 Types of Software Metrics $\ldots \ldots \ldots \ldots \ldots \ldots \ldots$

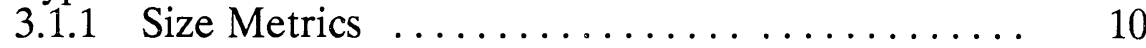

3.1.2 Token Count Metrics $\ldots \ldots \ldots \ldots \ldots \ldots \ldots . \quad 11$

3.1.3 McCabe's Cyclomatic Complexity Metric ..... 12

3.1.4 Residual Complexity Metrics .............. 12

3.1.5 Proposed Metrics ................... 13

3.1.5.1 Message Send Metrics ............. 13

3.1.5.2 Message Receive Metrics .......... 14

IV. EXPERIMENTAL PROCEDURE ............... 15

4.1 Experimental Definition $\ldots \ldots \ldots \ldots \ldots \ldots \ldots \ldots .15$

$4.2 \quad$ Experiment Planning . . . . . . . . . . . . . . . . . 16

4.3 Experiment Operation ................... 16

4.3.1 Design of the Questionnaire $\ldots \ldots \ldots \ldots \ldots . \quad 17$

4.3.2 Software Used to Gather the Data ......... 18

V. ANALYSIS OF THE MEASUREMENTS ........... 34

$5.1 \quad$ Choice of a Statistical Test $\ldots \ldots \ldots \ldots \ldots \ldots \ldots . \ldots \ldots$

5.2 Inter-metric Correlations $\ldots \ldots \ldots \ldots \ldots \ldots \ldots \ldots . .35$

5.3 Analysis of the Subjective Ratings ............. 40

5.4 Proposed Models $\ldots \ldots \ldots \ldots \ldots \ldots \ldots \ldots .45$

VI. EPILOGUE AND FUTURE WORK $\ldots \ldots \ldots \ldots \ldots \ldots .51$

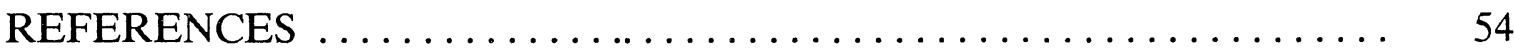

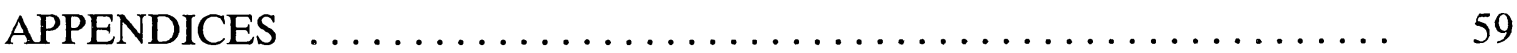

APPENDIX A - A SAMPLE PROGRAM $\ldots \ldots \ldots \ldots \ldots . .60$ 
APPENDIX B - THE QUESTIONNAIRE AND

THE EXPERTS' REPLIES

APPENDIX C - PC-MÉTRIC REPORTS AND THE LISTING OF RESERVED AND NON-EXECUTABLE

WORDS

APPENDIX D - PARALLEL PROGRAM TO COLLECT

SIZE MEASUREMENTS

APPENDIX E - PSEUDO CODE, FILE LISTING,

AND MAKEFILE

APPENDIX F - PARALLEL PROGRAM TO COLLECT

COMMUNICATION MEASUREMENTS .... 97

APPENDIX G - INTER-METRIC CORRELATION

ANALYSES

APPENDIX H - VARIABLES USED IN THE REGRESSION ANALYSES

APPENDIX I - REGRESSION ANALYSES ............ 148 


\section{LIST OF TABLES}

Table

Page

I. A General Categorization of the Parallel Programs Used in the Study $\ldots \ldots \ldots \ldots \ldots \ldots \ldots \ldots \ldots \ldots \ldots . \ldots \ldots \ldots$

II. Experts' Education and Experience Level .............. 18

III. Cyclomatic Complexity Measurements ................ 24

IV. Software Science Measurements $\ldots \ldots \ldots \ldots \ldots \ldots \ldots \ldots 25$

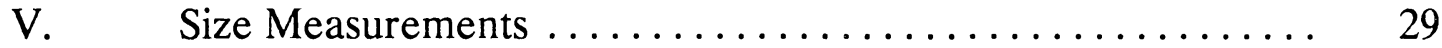

VI. Communication Complexity Measurements $\ldots \ldots \ldots \ldots . . . .30$

VII. Residual Complexity Measurements $\ldots \ldots \ldots \ldots \ldots \ldots . . \ldots 32$

VIII. Extracted Size Measurements ................... 36

IXa. Important Correlations Among the Experts' Replies ....... 42

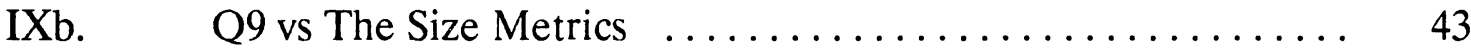

IXc. Q9 vs The Software Science Metrics $\ldots \ldots \ldots \ldots \ldots \ldots . . . . .44$

IXd. Q9 vs The Cyclomatic Complexity Metrics $\ldots \ldots \ldots \ldots \ldots 44$

IXe. Q9 vs The Communication Metrics $\ldots \ldots \ldots \ldots \ldots \ldots . . \ldots$

IXf. $\quad$ Q9 vs The Residual Metrics $\ldots \ldots \ldots \ldots \ldots \ldots \ldots \ldots \ldots \ldots \ldots$ 


\section{LIST OF FIGURES}

Figure

Page

1. QUESTIONS 5 THROUGH 10 OF THE QUESTIONNAIRE. 41

2. SAMPLE PC-METRIC REPORT BY PROCEDURE ...... 77

3. SAMPLE PC-METRIC REPORT BY COMPLEXITY

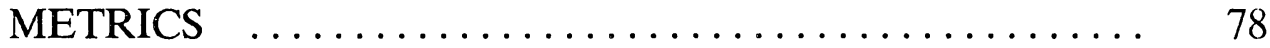




\section{CHAPTER I}

\section{INTRODUCTION}

We have all encountered various types of failures or collapses. For instance, generally speaking, a building can collapse because of engineering defects and an automobile can collapse because of engine failure. In computer science, software fails not just because of hardware failure, but most of the time because of the lack of due consideration to the field of software engineering while developing that particular software.

The field of software engineering has existed for the past three decades [Goldberg86] and has been defined by Boehm [Boehm81] as,

... the application of science and mathematics by which the capabilities of computer equipment are made useful to man via computer programs, procedures, and associated documentation.

Conte et al. [Conte86] summarized the goal of software engineering as: "... to produce higher quality software at lower cost."

Software engineering has several fields. One of these fields is the study of static measurements of programs as indicators of repairability, clarity, complexity, reliability, number of faults, productivity, quality, etc. These measurements are expressed by using the concept of metrics. In general, metrics can be applied to many different levels of a computer system in both software and hardware areas.

Generally speaking, software complexity can be perceived as clarity, understandability, or ease of modifying and debugging programs. Software complexity metrics thus attempt to objectively measure the difficulty involved in 
developing and maintaining programs. Several metrics have been proposed and evaluated for sequential programs. Parallel software, despite its rapid growth, currently lacks software complexity metrics.

One way to begin to address the question of the complexity of parallel programs is by exploring the parallel aspects of the software complexity issue. The purpose of this thesis is to apply the existing software metrics to parallel programs and construct new metrics specifically suited for parallel programs.

Several parallel machines are available commercially with different types of architectures. Each machine has a different operating system and hence different applications software. The programs that were analyzed as part of this thesis were made available, upon a request by the author, by Dr. G. B. Lamont of Air Force Institute of Technology (AFIT), Dayton, Ohio. These programs had been written specifically for the Intel's iPSC family of supercomputers [Intel88]. TABLE I gives a general overview of the parallel programs in the compendium in terms of their size, hardware used, Lines of Code, and McCabe's $V(G)$ (discussed in Section 3.1.3). Intel's iPSC was chosen for this study because of its existence on Oklahoma State University (OSU) campus and availability to graduate students.

Chapter 2 of this thesis gives a brief review of the history of parallelism and software metrics used in this study. Chapter 3 includes a discussion of the metrics considered for this study. Chapter 4 discusses the experimental methodology utilized. Analysis of the measurements is included in Chapter 5. Chapter 6 summarizes the main conclusion and elucidate some possible areas of future work. 
TABLE I

A GENERAL CATEGORIZATION OF THE PARALLEL

PROGRAMS USED IN THE STUDY

\begin{tabular}{|c|c|c|c|c|}
\hline $\begin{array}{l}\text { Application } \\
\text { Type }\end{array}$ & $\begin{array}{l}\text { Hardware } \\
1=i P S C / 1 \\
2=i P S C / 2\end{array}$ & $\begin{array}{c}\text { Number } \\
\text { of } \\
\text { Programs }\end{array}$ & LOC * Range & $\begin{array}{l}\text { McCabe's } \\
\text { V(G) }\end{array}$ \\
\hline $\begin{array}{l}\text { Ring } \\
\text { Simulatıon }\end{array}$ & $1 \& 2$ & 2 & $225-275$ & $10-12$ \\
\hline $\begin{array}{l}\text { Mesh Network } \\
\text { Simulation }\end{array}$ & 1 & 4 & $150-300$ & $10-30$ \\
\hline $\begin{array}{l}\text { Sorts (Bitonic } \\
\text { Odd-Even,Radix) }\end{array}$ & $1 \& 2$ & 7 & $600-1200$ & $60-110$ \\
\hline Heap Sort & $1 \& 2$ & 6 & $225-500$ & $20-60$ \\
\hline Neural Network & 1 & 2 & $500-1000$ & $35-130$ \\
\hline $\begin{array}{l}\text { Travelling } \\
\text { Salesman }\end{array}$ & 1 & 2 & $1150-1250$ & $130-135$ \\
\hline $\begin{array}{l}\text { Set Covering } \\
\text { Problem }\end{array}$ & 2 & 3 & $4000-14000$ & $250-1200$ \\
\hline $\begin{array}{l}\text { Partial } \\
\text { Differential }\end{array}$ & 1 & 1 & 700 & 70 \\
\hline Graph Search & 1 & 1 & 800 & 50 \\
\hline $\begin{array}{l}\text { Assignment } \\
\text { Problem }\end{array}$ & 1 & 1 & 1300 & 160 \\
\hline $\begin{array}{l}\text { Matrix } \\
\text { Multiplication } \\
\text { \& Inversion }\end{array}$ & 1 & 1 & 525 & 40 \\
\hline $\begin{array}{l}\text { Dining } \\
\text { Philosophers }\end{array}$ & 1 & 2 & $600-725$ & $30-60$ \\
\hline
\end{tabular}

* Here LOC represents the total length of a parallel program in terms of lines of code including blank and comment lines

** A parallel implementatıon of the Assignment Problem usıng the Hungarian Method [Compendium90] 


\section{CHAPTER II}

\section{PARALLELISM: HISTORY AND HARDWARE}

Concurrent or parallel architectures are not new. Even John von Neumann, whose ideas lead to the development of the sequential architecture that is used in most computers today, preferred the parallel approach [Rattner85]. However, the technological barriers of the time, such as unreliability of vacuum tubes, distanced the idea from its practical implementation.

In late 1960s several parallel machines were introduced, including the 64processor ILLIAC IV [Hayes88] at the University of Illinois. The ILLIAC IV's limited memory and expensive hardware kept it away from commercial use. The evolution of the cost-effective Very Large Scale Integrated (VLSI) technology in 1970s [Hayes88] stimulated interest in developing parallel computers for commercial use. In 1980s several vendors introduced parallel machines with different architectures and topologies. Each of them has some advantages and disadvantages over others. Some of the better known parallel computers are: Butterfly GP1000 of BBN Advanced Computers Incorporation with local or shared memory and switch interconnection topology [BBN89], Multimax 520 of ENCORE Computers with shared memory and bus topology [Encore89], and iPSC/2 of Intel Scientific Computers with local (distributed) memory and hypercube interconnection topology [iPSC88 and Intel88]. Programs chosen to study in this thesis were exclusively written for Intel's iPSC family of computers. 


\subsection{Definition of Parallel Processing}

In most of the available literature, the terms concurrent and parallel have generally been used interchangeably. Fox [Fox88] defined concurrent processing as:

... the use of several working entities (either identical or heterogeneous), working together toward a common goal.

In concurrent computation, Fox considers the working entities as computers and the goal as a large computation problem, such as weather prediction.

\subsection{Types of Parallelism}

Stone [Stone87] discusses two types of parallelism: coarse-grain and finegrain. He states that in general the performance benefits of a multiprocessor machine strongly depend on the ratio $\mathrm{R} / \mathrm{C}$, where $\mathrm{R}$ is the length of a run-time quantum and $\mathrm{C}$ is the length of the communication overhead incurred during that quantum. Stone uses the ratio $\mathrm{R} / \mathrm{C}$ as a measure of task granularity and states that in coarse-grain parallelism $\mathrm{R} / \mathrm{C}$ is relatively high, such that each run-time quantum generates a relatively small amount of communication overhead. On the other hand, in fine-grain parallelism, $\mathrm{R} / \mathrm{C}$ is very low, hence it causes a relatively large amount of communication overhead during each run-time quantum.

In this thesis we are not putting any emphasis on the dynamic aspects of application programs. Instead we are taking the source code that is running correctly, and analyzing it in a number of different ways that are described later.

\subsection{Intel's iPSC Concurrent Supercomputers}

The first version of Intel's iPSC Concurrent Supercomputer was introduced in mid 1980s and was named iPSC. This first version (later known as iPSC/1) was 
based on the hypercube architecture [Seitz85] and had Intel's 80286 microprocessor with the $\mathrm{XENIX}^{1}$ operating system. In the late 1980s, Intel introduced its new version and named it $\mathrm{iPSC} / 2$. The new version has a 80386 microprocessor and a number of added features over iPSC/1, such as SX scalar processor, UNIX V.3 operating system [UNIX86], and the Direct-Connect Module (DCM) [Nugent88]. DCM is a specialized hardware that controls the message passing system and is attached to each hypercube node.

The iPSC/2 system consists of compute nodes, I/O nodes, and a front-end processor called host. Each node is a processor-memory pair, with distinct memory from host and other nodes. Each node runs its own copy of NX/2 [Pierce88] operating system. The $\mathrm{NX} / 2$ operating system is written almost entirely in $\mathrm{C}$ and can manage up to 20 processes per node. It also manages the numeric coprocessors for each process on a node. The front-end processor is called the System Resource Manager (SRM) or the local host. SRM runs the UNIX operating system. The host program executes in the UNIX environment and provides the user interface and, if needed, loads the node program to each node. It also provides true 32-bit node architecture performance [Close88].

In both iPSC/ 1 and iPSC/2, concurrency is achieved by grouping looselycoupled independent processing elements executing portions of a larger computational problem simultaneously. All parallel application programs run over an iPSC consist of at least two modules. One module runs on the front-end SRM and the other runs on each participating node. In general, a module running on a local host is known as a host module and a module running on nodes is known as a node module.

The following is an example of solving a sequential problem with a parallel algorithm on an iPSC machine. Example 1 shows how developing a parallel 1 XENIX is a registered trademark of Microsoft Corporation. 
algorithm for a problem is in general more complex in terms of logic design and program writing than developing a sequential algorithm for the same problem. The program for Example 1 appears in Appendix A.

Example 1: Given a parallel machine such as iPSC/2, we need to sum the numbers from 1 to 100 on its p processors. Suppose $p=1$, that is, we have a one-processor machine to sum the integers from 1 to 100 . Assuming that adding two integers takes one time unit, to sum the integers from 1 to 100 would take 99 time units. On a uniprocessor platform, a parallel algorithm to sum the integers from 1 to 100 would take almost the same number of time units as a sequential algorithm.

Now suppose we have two processors $(p=2)$ to sum the integers from 1 to 100. We can assign half of all the integers involved in the summation to each processor, that is, in the case of the integers from 1 to 100 , each processor will get 50 integers to sum. In this way, generally speaking, integers from 1 to 100 can be summed in approximately half of the time that it would take to sum them on one processor. Hence, in terms of processing time or speed-up, we can achieve almost a $100 \%$ gain. But to achieve this gain we have to change our parallel algorithm such that the range can be divided by the number of processors available. This change in the algorithm may increase its complexity.

Now consider $p=3$. Obviously in this case we cannot divide 100 integers (from 1 to 100) into 3 equal ranges. We have to change our parallel summation algorithm again to get the optimal processing time. In the case of three processors, our algorithm should be able to assign 33 integers to two of the three processors, and 34 integers to the third processor. Developing an algorithm that could handle this uneven assignment of the ranges to processors may take some extra effort and may also make the programming task more difficult and complex in terms of the lines of code and time spent in writing it. 
From the above example, the following observation can be made: the static complexity of software involved in parallel processing probably has more dimensions or aspects than the static complexity of software on conventional (sequential) computers, even though the basic issues (i.e., understandability, quality, maintainability, etc.) are the same. 


\section{CHAPTER III}

\section{SOFTWARE METRICS}

Because of the intuitive relationship between conceptual complexity and software quality, several studies have focused attention on the development and validation of a set of quantitative metrics to measure the complexity of software. Intuitively speaking, parallel software is more difficult to understand than sequential software. This is in general true because of the differences in the programming languages, programming environments, and specially the architectures of sequential and parallel machines, and the difficulty of visualizing parallel execution. Also, since sequential and parallel programs can be considered different as far as understandability is concerned, it is not advisable to use metrics developed for sequential programs on parallel programs without first validating them for suitability. This spawned the need to develop parallel software metrics.

\subsection{Types of Software Metrics}

Several metrics have been developed and studied for measuring the complexity of sequential software as well as hardware for different machines and languages. Some of the metrics developed for software are cyclomatic complexity [McCabe76], software science metrics [Halstead77], and information flow metrics [Henry79]. However, none of the software metrics or analyses have been carried out for the $\mathrm{C}$ programming language on iPSC machines. The performance evaluation of parallel systems from the hardware aspect has also been the subject of 
several studies [Zuberek85]. Work done by Haban and Wybranietz [Haban89] on monitoring and measuring parallel systems can be noted here.

Conte et al. [Conte86] discussed several types of metrics, such as Size, Data structure, Logic structure, Software Science, Effort, and Cost. They indicated that program complexity increases with size and that large programs are generally more difficult to understand and write, contain relatively more errors, and are more difficult to debug. To reduce this complexity, software designers have increasingly turned to program modularization and structured design methodologies. The advantages of program modularization are typically expressed in terms of comprehensibility, manageability, efficiency, error reduction, and reduced maintenance effort. Conte et al. state that not all computer scientists agree on these advantages and some consider program modularization a disadvantage because the need for proper interfacing among the modules increases as the number of modules grows.

\subsubsection{Size Metrics}

The size of a program is a well-known and widely-accepted measure and is still considered a basic measure for some models of software development, and cost and schedule estimation. The size metric can be calculated in several ways. One way is by counting the number of lines of code and another is by counting the tokens.

Size metric measured in terms of lines of code may not be satisfactory for modern programming languages because not all lines in a program may have the same level of difficulty in their production. Some of the lines in a program may have fewer tokens and hence be in general less difficult to produce than other lines in the same program. However, lines of code (LOC) is still the most widely-used 
size metric. Lines of code is defined by Conte et al., as the sum of all noncommented and non-blank lines. This definition is used in this thesis for size metric.

\subsubsection{Token Count Metrics}

Halstead [Halstead77] viewed a program as a sequence of tokens, which could be either operands representing data or operators manipulating the operands. Halstead's four basic counts are as follows.

$$
\begin{aligned}
& \mathrm{n}_{1}: \text { Number of unique operators } \\
& \mathrm{n}_{2} \text { : Number of unique operands } \\
& \mathrm{N}_{1} \text { : Total occurrences of operators } \\
& \mathrm{N}_{2} \text { : Total occurrences of operands }
\end{aligned}
$$

There is no general agreement among researchers regarding exactly which tokens in a given language are operators and which are operands. This makes a general consensus regarding token counting hard to reach. Conte et al. suggested that the classification of a token as operators or operands should be determined by the programmer who is developing the counting tool.

Halstead defined various metrics based on these four basic counts, some of them are listed below.

The vocabulary $n$ is defined as $n=n_{1}+n_{2}$

The program length $\mathrm{N}$ is given by $\mathrm{N}=\mathrm{N}_{1}+\mathrm{N}_{2}$

The estimated program length is defined as

$$
\mathrm{N}_{\text {est }}=\mathrm{n}_{1} * \log \left(\mathrm{n}_{1}\right)+\mathrm{n}_{2}{ }^{*} \log \left(\mathrm{n}_{2}\right)
$$

(All logarithms are base 2 unless explicitly stated otherwise.) 


\subsubsection{McCabe's Cyclomatic Complexity Metric}

McCabe [McCabe76] suggested a metric to measure the maintenance difficulty of a program based on the number of different independent paths through it. These independent paths through a program add to the complexity of testing a program, as experienced by programmers. He suggested a control flow metric, based on the number of conditions (such as the "if" statements in a program) which he called the cyclomatic complexity. The cyclomatic complexity is defined as

$$
\mathrm{V}(\mathrm{G})=\mathrm{e}-\mathrm{n}+2 \mathrm{p}
$$

where $\mathrm{e}$ is the number of edges, $\mathrm{n}$ is the number of nodes, and $\mathrm{p}$ is the number of connected components in the control flow graph of a program. An alternative formulation of the cyclomatic complexity is

$$
\mathrm{V}(\mathrm{G})=\operatorname{Pr}+1
$$

where $\operatorname{Pr}$ is the number of predicates in the program. $V(G)$ can be easily calculated using this alternate form.

\subsubsection{Residual Complexity Metrics}

Samadzadeh and Edwards [Samadzadeh88] proposed a metric called the residual complexity which measures the remaining complexity in a software document after some attempt has been made to understand it by conceptually subdividing or chunking it. They argue that a software document can be thought of as a set of tokens of different types. In an abstract view of the classification part of the comprehension process, a user trying to understand a software document examines individual tokens and finds the class to which each token belongs. Each classification represents a level of understanding and refinement of a classification or partition signifies an improvement in understanding. After all the tokens have 
been classified at a certain level of comprehension, the as yet uncovered portion of the software complexity can be represented as

$$
\mathrm{R}=\mathrm{N}_{1} * \log \left(\mathrm{N}_{1}\right)+\mathrm{N}_{2} * \log \left(\mathrm{N}_{2}\right)+\ldots+\mathrm{N}_{\mathrm{q}}{ }^{*} \log \left(\mathrm{N}_{\mathrm{q}}\right)
$$

where $\mathrm{R}$ is the residual complexity metric and $\mathrm{N}_{\mathrm{i}}, \mathrm{i}=1,2, \ldots, \mathrm{q}$, is the number of tokens in the ith class or block of the current partition.

\subsubsection{Proposed Metrics}

In an attempt to modify the cyclomatic complexity for a parallel algorithm, we can consider all message passing/receiving commands as virtual conditional statements. This assumption can be intuitively supported by the argument that for any message passing/receiving command the program control jumps to another location, thus increasing the difficulty of comprehending the program.

The following are some of the metrics proposed specifically for parallel programs.

\subsubsection{Message Send Metrics}

Three types of "Send" metrics can be identified:

i. Host Send metric;

ii. Node Send metric; and

iii. Total Send metric.

Host Send metric $\left(\mathrm{H}_{\mathrm{S}}\right)$ is the sum of all message send commands appearing in the host program of an application, which may or may not have a corresponding message receive command in the same application. Node Send metric $\left(\mathrm{N}_{\mathrm{S}}\right)$ is the sum of all message send commands appearing in a node program of an application, which may or may not have a corresponding message receive command in the same 
application. Finally, Total Send metric $\left(\mathrm{T}_{\mathrm{S}}\right)$ is the sum of all message send commands in an application, $\mathrm{T}_{\mathrm{S}}=\mathrm{H}_{\mathrm{S}}+\mathrm{N}_{\mathrm{S}}$.

\subsubsection{Message Receive Metrics}

The definitions of Message Receive Metrics are analogous to those of the Message Send Metrics. Three types of "Receive" metrics can be identified:

i. Host Receive metric;

ii. Node Receive metric; and

iii. Total Receive metric.

Host Receive metric $\left(\mathrm{H}_{\mathrm{r}}\right)$ is the sum of all message receive commands appearing in the host program of an application, which may or may not have a corresponding message send command in the same application. The node Receive metric $\left(\mathrm{N}_{\mathrm{r}}\right)$ is the sum of all message receive commands appearing in a node program of an application, which may or may not have a corresponding message send command in the same application. Total Receive Metric $\left(\mathrm{T}_{\mathrm{r}}\right)$ is the sum of all message receive commands in an application, $\mathrm{T}_{\mathrm{r}}=\mathrm{H}_{\mathrm{r}}+\mathrm{N}_{\mathrm{r}}$. 


\section{CHAPTER IV}

\section{EXPERIMENTAL PROCEDURE}

This chapter describes the experimental methodology used in the design of this study including the framework adopted for experimentation, data collection methodology, and the static metrics gathered and their analyses. Models derived based on both the experts' perceptions and the static metrics are also discussed.

The framework of experimentation defined by Basili et al. [Basili86] was, used in the design of this study. This choice was made because of the wide acceptance of their framework in the field of software engineering and related research areas. According to Basili et al.'s framework, there are four stages in the experimentation process: 1) definition, 2) planning, 3) operation, and 4) interpretation. The definition, planning, and operation stages are described below. The fourth category, interpretation, will be discussed in the following chapter.

\subsection{Experiment Definition}

This study was devised to understand (motivation) the parallel aspects of software complexity. The purpose of the study was to conduct an exploratory empirical study of academic programs (domain) written in iPSC/2-C [Green89] on Intel's iPSC family of concurrent supercomputers. Initially, over 35 programs written by eight graduate students of a particular graduate level class were evaluated, both by using metrics and from the perspective of a number of experts in parallel programming. Nineteen parallel programs written by eight graduate students were chosen for final evaluation. The reasons for the exclusion of some 
programs and the criteria for the inclusion of the programs selected for final analysis is discussed in Section 4.3.1. There were four subjects who ranked the programs based on the questions asked, according to their best judgement. The subjects had considerable experience in the field of parallel programming specially on the iPSC family of concurrent computers.

\subsection{Experiment Planning}

Only the syntactically correct and properly running programs were included in the study. An objective as well as subjective assessment of static measurements in a multivariate design was proposed. The programs were to be evaluated based on the metrics described in Chapter 3. A non-parametric test was chosen for correlation analysis in consultation with Dr. P. Larry Claypool, Professor of Statistics, at Oklahoma State University, and Dr. William L. Woodall, Professor of Statistics, at the University of Alabama. This choice was made because limited data were available and distributional assumptions could not be met. The data consisted of both objective as well as subjective measurements. The correlation analysis was used to study the possible relationships between static metrics and the experts' ratings of the complexity of programs.

\subsection{Experiment Operation}

The next two subsections explain the design of a questionnaire to glean and compile the experts' judgements and the software tools that were developed and/or used to collect the metrics. Some of the problems encountered are also described briefly. 


\subsubsection{Design of the Questionnaire}

A questionnaire (Appendix B.1) was devised to capture the experts' subjective perception of the relative complexity of the 37 programs included in the study. In the questionnaire, each application was mentioned with its complete directory path in the compendium. The questionnaire had 10 questions. The first four questions were included to judge the participants' expertise and experience level. This was necessary to make sure that the participants had enough experience in the field of parallel processing to judge parallel programs. Questions 5 through 10 were designed to elicit the judgement of the participants regarding the programs used in the study. In fact Questions 1 through 4 serve as a pretest and Questions 5 through 10 serve as a posttest [Conte86]. Some of the questions asked in the questionnaire were redundant. This was done intentionally to compare the consistency in the participants' replies. For instance, question 9 asks to rate the overall complexity of an application whereas in questions 5 and 6 the understandability of the host and the node programs were requested to be rated. Intuitively speaking, the replies should be in the form of opposite ranking, e.g., if three applications $\mathrm{A}, \mathrm{B}$, and $\mathrm{C}$ are ranked as 1,2 , and 3 by questions 5 and 6 . then the same applications should be ranked as 3,2 , and 1 by question 9 . The above expectation was met when correlation analysis was done on the experts' replies (see Section 5.3, TABLE IXa).

It was expected that not all the participants in the study would be familiar with each of the application included in the study. Hence, in the questionnaire, the participants were requested to record their judgement only for those applications with which they were familiar. This instruction was to give the participants a feeling that they were not obliged to rate each application for every question. As a general 
rule, this also helps restrict the outliers. Thus the ratings across the application names that were left blank, were assumed to be unanswered.

Participation in the study was voluntary. Out of the original 10 experts targeted in this study, four replied. All four participants had adequate experience and education. Their education and experience in the field of parallel processing is given in TABLE II. Among the 37 application originally included in the study, 19 were judged by all the participants. One application, i.e., "project/beard/src/thesis/parallel", was found to be an outlier even though it was rated by all the participants. This particular application has approximately 14,000 lines of code. Although the Spearman Rank Correlation Coefficient test (discussed in Section 5.1) takes care of bad outliers, it was dropped from the study because the above application was affecting the mean values drastically.

TABLE II

EXPERTS' EDUCATION AND EXPERIENCE LEVEL

\begin{tabular}{c|c|c}
\hline $\begin{array}{c}\text { Number of } \\
\text { Partıcipants }\end{array}$ & $\begin{array}{c}\text { Highest Academıc } \\
\text { Degree }\end{array}$ & $\begin{array}{c}\text { Parallel Processing } \\
\text { Experience }\end{array}$ \\
\hline 1 & Ph. D. & 5 Years \\
\hline 2 & M.S. & 2 Years \\
\hline 1 & B.S. & 2 Years \\
\hline
\end{tabular}

\subsubsection{Software Used to Gather the Data}

Among the three pre-written software packages [Bishop87, Graham83, and PCMETRIC90] initially thought to be useful in collecting various static measurements, the commercially available tool PC-METRIC was chosen to collect 
some of the data because of its availability on campus. The rest of the data collection was achieved through the programs developed on the iPSC/2 concurrent supercomputer.

PC-METRIC is a microcomputer-based software tool that runs under the Disk Operating System (DOS) [DOS87]. It expects as input any syntactically correct and compilable $\mathrm{C}$ program and generates a report. The report contains a set of two complexity metrics: the Software Science family of metrics and the cyclomatic complexity metrics.

An advantage of using PC-METRIC was that it considers a $\mathrm{C}$ source code file as a series of tokens. All of the reserved and non-executable words used in an input $\mathrm{C}$ source file can be defined in an external file which is used by the tool at run time. Thus it does not matter which flavor of the $\mathrm{C}$ programming language is used for the analyses. The author of this study took advantage of this facility and used PC-METRIC to extract static measures from the parallel programs written in the iPSC/2-C programming language [Green89].

There is an exception to the flexibility of PC-METRIC. Programs written in the Pascal programming language style cannot be analyzed using PC-METRIC even if they are syntactically correct and properly compilable programs (see Example 2).

Example 2:

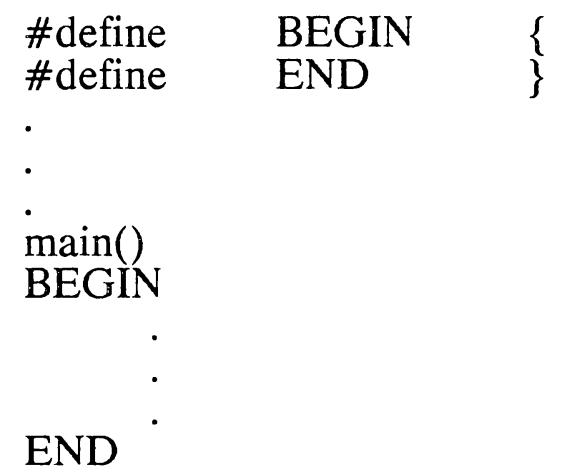

(Source: User's Guide for C, PC-METRIC, ver. 1.0, Set Laboratories, Inc., Mulino, Oregon, pp 3-12, 1990.) 
This is because PC-METRIC uses braces or curly brackets (i.e., "\{" and "\}") as delimiters of the body of the executable code.

If most of the source code is written in the Pascal style, the PC-METRIC's User's Guide recommends that the source file should be run through a preprocessor, which is a utility program available on the iPSC/2, to avoid spurious results. Empty procedures such as

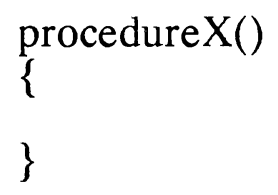

may also produce spurious results, and should be taken out prior to the final analysis of an input source code file.

Before using PC-METRIC, some issues had to be resolved. As mentioned above, the tool is a PC-based software, thus all the programs in the compendium had to be down-loaded onto a floppy disk in ASCII (American Standard Code for Information Interchange) format prior to evaluation. Each application was given the same path and name as it had in the compendium except when it was prohibited by the DOS naming conventions.

PC-METRIC can be executed in four modes: Interactive, Command Line, Indirect, and Batch [PCMETRIC90]. The interactive mode was found to be the most convenient and was chosen for the source code analyses.

The normal output of PC-METRIC consists of two files < filename $>$.RPT and $<$ filename $>$.EXP. The file with extension .RPT contains a complexity analysis report on a procedure by procedure basis and a complexity summary for the entire file. The file with extension .EXP contains the listing of all procedures which 
exceed predefined complexity standards [PCMETRIC90]. Another file with the extension .ERR is created if errors are encountered. Figures C.2 and C.3, in Appendices C.1 and C.2, depict a sample output report generated by this software tool.

A few other points are also worth to mentioning here about PC-METRIC. For instance, if a statement such as

$$
\text { \#define symb }
$$

encountered, then symb will be defined through the analysis of all the files or until a \#undef symb statement is encountered. Contrary to this, a statement such as

$$
\text { \#define } \quad \text { FALSE } 0
$$

is not considered as a definition of a symbol (in this case FALSE) that is, any time the symbol is assigned a value, it is ignored. The header (.h) file or files must be entered or selected first among the source files to be analyzed so that all the definitions can be picked up.

Another point found interesting was the way PC-METRIC handles the occurrences of parentheses. In C, parentheses are used for three purposes: after a control statement, after a procedure call, or to change the default ordering of arithmetic operations. To differentiate between these uses, three different types of parenthesis have been defined in the reserved-word file (Appendix C.3). These three types were represented as '(c', '(p', and '(', respectively. Similarly, asterısk '*' and ampersand '\&' each have two uses and hence are defined separately in the reserved-word file. Asterisk '*' is used to indicate the multiplication sign and '* $\mathrm{p}$ ' to 
indicate a pointer. Similarly, ampersand ' $\&$ ' is used to indicate the unary AND and '\&p' to indicate the address operator.

The cyclomatic complexity was considered for this study because it counts the operators '\&\&' and ' $\mid$ ', as well as the regular decision operators such as 'if', and 'while'. The counting strategy adopted in PC-METRIC was a modified form of the counting strategy discussed by Conte et al. [Conte86] for Pascal programs and implemented by Moll and Samadzadeh [Moll89] (refer to [PCMETRIC90] for a complete counting strategy used to collect the measurements).

The following two paragraphs describes the data collection procedure used to extract static measures from the parallel programs.

As mentioned above, that all the parallel programs included in the final analyses were ported to a microcomputer. Subsequently, the available tool was used to collect some of the Software Science metrics and McCabe's cyclomatic complexity metrics. However, before generating any report, the files for reservedwords and non-executable words were checked to make sure that all reserved and non-executable words are defined in the appropriate files.

As explained in Section 2.3, parallel programs for the iPSC/2 are each divided into two modules. One which runs on the host processor and the other which runs on the node processors. Each module may or may not contain more than one file. Halstead's Software Science metrics and McCabe's cyclomatic metrics were extracted from the programs. For Halstead's metrics, $n_{1}, n_{2}, N_{1}, N_{2}$, and the Effort $\mathrm{E}$ were collected for the host as well as for the node programs by feeding the files related to each module to the available tool as input. Token count for the whole application was measured by adding the operators and operands of each module instead of inputting all the files in the host and the node modules to the available tool. This was because each module was a separate entity, and a variable 
used in a program related to the host module had no relation with a variable used in the node module with the same name as shown in Example 3.

Example 3:

Host Program (host.c)

$\operatorname{main}()$

\{

result $=1$;

if $($ result $==1)$

….

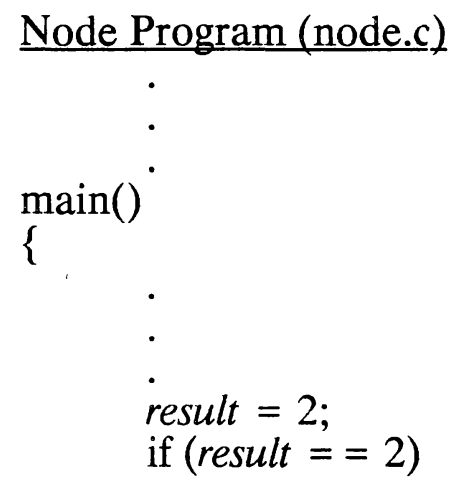

\}

In the above example, suppose the programs host.c and node.c were input together to PC-METRIC, then it would consider the variable 'result' as a single unique operand. Intuitively speaking, the variable 'result' in the programs host.c and node.c constitutes two separate operands, and hence should be counted as two unique operands.

The above approach was adopted in measuring McCabe's cyclomatic complexity metrics also, even though for this metric the files involved in both modules could be input together to the tool. TABLES III and IV contain the static measurements for selected McCabe's cyclomatic metrics and Halstead's Software Science metrics, respectively. 
TABLE III

CYCLOMATIC COMPLEXITY MEASUREMENTS

\begin{tabular}{|c|c|c|c|}
\hline Apl\# & Host V(G) & Node $V(G)$ & Total V(G) \\
\hline 1 & 4 & 6 & 10 \\
\hline 2 & 2 & 12 & 14 \\
\hline 3 & 16 & 65 & 81 \\
\hline 4 & 47 & 62 & 109 \\
\hline 5 & 46 & 107 & 153 \\
\hline 6 & 28 & 30 & 58 \\
\hline 7 & 33 & 40 & 73 \\
\hline 8 & 4 & 17 & 21 \\
\hline 9 & 4 & 17 & 21 \\
\hline 10 & 11 & 25 & 36 \\
\hline 11 & 8 & 15 & 23 \\
\hline 12 & 12 & 138 & 150 \\
\hline 13 & 4 & 29 & 33 \\
\hline 14 & 6 & 127 & 133 \\
\hline 15 & 6 & 127 & 133 \\
\hline 16 & 5 & 42 & 47 \\
\hline 17 & 6 & 152 & 158 \\
\hline 18 & 18 & 27 & 45 \\
\hline
\end{tabular}

For application names see Appendıx B 2 
TABLE IV

SOFTWARE SCIENCE MEASUREMENTS

\begin{tabular}{|c|c|c|c|c|c|c|c|c|c|c|c|c|c|c|c|}
\hline \multirow[b]{2}{*}{ Apl\# } & \multicolumn{5}{|c|}{ Host Metrics } & \multicolumn{5}{|c|}{ Node Metrics } & \multicolumn{5}{|c|}{ Overall Applıcatıon Metrıcs } \\
\hline & $n_{1}$ & $\mathrm{n}_{2}$ & $N_{1}$ & $\mathrm{~N}_{2}$ & Effort & $\mathrm{n}_{1}$ & $\mathrm{n}_{2}$ & $N_{1}$ & $\mathrm{~N}_{2}$ & Effort & $\mathrm{n}_{1}$ & $\mathrm{n}_{2}$ & $N_{1}$ & $\mathrm{~N}_{2}$ & Effort \\
\hline 1 & 25 & 33 & 123 & 62 & 254510 & 30 & 29 & 151 & 80 & 562300 & 55 & 62 & 274 & 142 & 1800124 \\
\hline 2 & 23 & 19 & 69 & 36 & 123370 & 27 & 37 & 230 & 144 & 1179010 & 50 & 56 & 299 & 180 & 2589648 \\
\hline 3 & 38 & 31 & 223 & 136 & 1827940 & 51 & 77 & 1049 & 645 & 25329150 & 89 & 108 & 1272 & 781 & 50355641 \\
\hline 4 & 60 & 106 & 701 & 359 & 7942920 & 45 & 90 & 1068 & 647 & 19631170 & 105 & 196 & 1769 & 1006 & 61567993 \\
\hline 5 & 61 & 113 & 827 & 446 & 11405900 & 73 & 190 & 1993 & 1169 & 57083850 & 134 & 303 & 2820 & 1615 & 138922206 \\
\hline 6 & 50 & 68 & 583 & 316 & 7188410 & 47 & 60 & 532 & 294 & 6412070 & 97 & 128 & 1115 & 610 & 31153866 \\
\hline 7 & 54 & 88 & 737 & 416 & 10521910 & 49 & 75 & 781 & 445 & 12393740 & 103 & 163 & 1518 & 861 & 52131232 \\
\hline 8 & 28 & 34 & 201 & 105 & 787740 & 29 & 26 & 274 & 166 & 2354970 & 57 & 60 & 475 & 271 & 6597532 \\
\hline 9 & 29 & 40 & 218 & 121 & 908300 & 30 & 31 & 359 & 217 & 3586910 & 59 & 71 & 577 & 338 & 9023708 \\
\hline 10 & 30 & 38 & 210 & 108 & 825270 & 44 & 64 & 483 & 249 & 4232250 & 74 & 102 & 693 & 357 & 10142962 \\
\hline 11 & 30 & 37 & 195 & 100 & 725470 & 28 & 33 & 285 & 157 & 1746000 & 58 & 70 & 480 & 257 & 5492861 \\
\hline 12 & 45 & 59 & 327 & 189 & 2491980 & 62 & 124 & 1539 & 1010 & 48523720 & 107 & 183 & 1866 & 1199 & 87882181 \\
\hline 13 & 29 & 42 & 138 & 86 & 409000 & 39 & 49 & 540 & 355 & 8167410 & 68 & 91 & 678 & 441 & 13483257 \\
\hline 14 & 36 & 57 & 279 & 151 & 1340800 & 56 & 102 & 1847 & 1278 & 80073070 & 92 & 159 & 2126 & 1429 & 117158813 \\
\hline
\end{tabular}


TABLE IV (continued)

SOFTWARE SCIENCE MEASUREMENTS

\begin{tabular}{c|ccccc|rcccc|ccccc}
\hline & \multicolumn{4}{|c|}{ Host Metrics } & \multicolumn{5}{c|}{ Node Metrics } & \multicolumn{5}{c}{ Overall Application Metrics } \\
\hline Apl\# & $n_{1}$ & $n_{2}$ & $N_{1}$ & $N_{2}$ & Effort & $n_{1}$ & $n_{2}$ & $N_{1}$ & $N_{2}$ & Effort & $n_{1}$ & $n_{2}$ & $N_{1}$ & $N_{2}$ & Effort \\
\hline 15 & 35 & 56 & 239 & 131 & 985730 & 53 & 97 & 1714 & 1188 & 68085610 & 88 & 153 & 1953 & 1319 & 98209709 \\
\hline 16 & 35 & 60 & 334 & 199 & 2032460 & 49 & 78 & 957 & 622 & 21559540 & 84 & 138 & 1291 & 821 & 41133043 \\
\hline 17 & 32 & 53 & 259 & 156 & 1252660 & 50 & 87 & 2565 & 1608 & 136865230 & 82 & 140 & 2824 & 1764 & 184740189 \\
\hline 18 & 36 & 72 & 438 & 281 & 3411880 & 39 & 54 & 593 & 379 & 8698980 & 75 & 126 & 1031 & 660 & 25413787 \\
\hline
\end{tabular}

For application names see Appendix B 2 
Since the available tool did not produce the extended size metrics (i.e., the number of blank and commented lines) and the communication metrics, two separate programs were developed to measure these metrics. For size metrics, a parallel program was developed (Appendix D) on the iPSC/2. The pseudocode of the program to collect size metrics is depicted in Appendix E.1. (because the same algorithm also was used in the program that collects the communication metrics).

The program collecting the size measures expects a syntactically correct parallel program as an input and produces as output four measures: the number of executable lines; the number of blank lines; the number of commented lines; and number of total lines in the input file. The size metric was divided into the above four categories so that analyses could be made to find out which metric or combination of metrics had more influence in terms of the comprehensibility of the parallel programs.

The program to extract the size measures is itself a parallel program. It has the capability to accept any number of files as input as there are nodes (processors) available on the system. The program processes all the input files at the same time (in a parallel fashion). However, since the iPSC/2 available on campus has 32 nodes, the program accepts a maximum of 32 files as input at one time and process them in parallel. The host module acts as a driver of the application and does the job of allocating a source code file to each node to extract the measurements. The host module is given access to a file that has a complete path listing of all the files that need to be processed (Appendix E.2). As soon as a node finishes extracting measurements from the file it was working on, it sends a message to the host with its node number and the collected metrics. The host receives the packet, saves the message and sends a new source file path to the same node. This process continues until all source files are processed. 
Another program was developed to collect the proposed communication metrics (Appendix F) on the iPSC/2. This program uses the same algorithm (Appendix E.1) as developed for the program collecting several size metrics. Again, the host module works as a driver and allocates files to each node whenever the nodes are free and in return collects communication measurements.

A makefile [Green89] was written to compile the newly developed tools (Appendix E.3). The outputs generated by the parallel programs used for gathering the size and the communication metrics were then manually added for the host and the node modules and are depicted in TABLES V and VI, respectively. 
TABLE V

SIZE MEASUREMENTS

\begin{tabular}{|c|c|c|c|c|c|c|c|c|c|c|}
\hline \multirow[b]{2}{*}{ Apl\# } & \multicolumn{3}{|c|}{ Host \# of Lines } & \multicolumn{3}{|c|}{ Node \# of Lines } & \multicolumn{3}{|c|}{ Total \# of Lines } & \multirow[b]{2}{*}{ Appl Length } \\
\hline & Exec & Blank & Comnt & Exec & Blank & Comnt & Exec & Blank & Comnt & \\
\hline 1 & 41 & 12 & 73 & 58 & 29 & 64 & 99 & 41 & 137 & 277 \\
\hline 2 & 29 & 8 & 22 & 79 & 19 & 74 & 108 & 27 & 96 & 231 \\
\hline 3 & 159 & 42 & 168 & 439 & 114 & 600 & 566 & 140 & 721 & 1427 \\
\hline 4 & 244 & 48 & 169 & 454 & 79 & 321 & 687 & 122 & 479 & 1288 \\
\hline 5 & 253 & 50 & 182 & 448 & 87 & 356 & 691 & 131 & 517 & 1339 \\
\hline 6 & 196 & 38 & 212 & 175 & 36 & 328 & 371 & 74 & 540 & 985 \\
\hline 7 & 244 & 56 & 233 & 235 & 43 & 378 & 479 & 99 & 611 & 1189 \\
\hline 8 & 66 & 25 & 56 & 102 & 31 & 71 & 168 & 56 & 127 & 351 \\
\hline 9 & 70 & 26 & 65 & 102 & 32 & 84 & 172 & 58 & 149 & 379 \\
\hline 10 & 45 & 9 & 60 & 116 & 16 & 113 & 161 & 25 & 193 & 379 \\
\hline 11 & 52 & 14 & 57 & 76 & 12 & 71 & 128 & 26 & 128 & 282 \\
\hline 12 & 138 & 48 & 151 & 349 & 110 & 442 & 487 & 158 & 593 & 1238 \\
\hline 13 & 62 & 26 & 22 & 150 & 55 & 246 & 212 & 81 & 268 & 561 \\
\hline 14 & 95 & 29 & 43 & 501 & 146 & 348 & 596 & 175 & 391 & 1162 \\
\hline 15 & 100 & 35 & 60 & 497 & 151 & 364 & 589 & 182 & 411 & 1182 \\
\hline 16 & 102 & 39 & 69 & 250 & 128 & 433 & 352 & 167 & 502 & 1021 \\
\hline 17 & 89 & 84 & 20 & 795 & 228 & 73 & 884 & 312 & 93 & 1289 \\
\hline 18 & 147 & 37 & 45 & 177 & 43 & 75 & 324 & 80 & 120 & 524 \\
\hline
\end{tabular}

For application names see Appendıx B 2 
TABLE VI

COMMUNICATION COMPLEXITY MEASUREMENTS

\begin{tabular}{|c|c|c|c|c|c|c|c|}
\hline \multirow[b]{2}{*}{ Apl\# } & \multicolumn{2}{|c|}{ Host Communication Mesgs } & \multicolumn{2}{|c|}{ Node Communication Mesgs } & \multicolumn{2}{|c|}{ Total Communication Mesgs } & \multirow[b]{2}{*}{ Total } \\
\hline & Send & Receive & Send & Receıve & Send & Receive & \\
\hline 1 & 1 & 2 & 4 & 3 & 5 & 5 & 10 \\
\hline 2 & 0 & 1 & 3 & 2 & 3 & 3 & 6 \\
\hline 3 & 3 & 2 & 2 & 2 & 5 & 4 & 9 \\
\hline 4 & 9 & 3 & 10 & 16 & 19 & 19 & 38 \\
\hline 5 & 9 & 3 & 10 & 16 & 19 & 19 & 38 \\
\hline 6 & 6 & 3 & 9 & 12 & 15 & 15 & 30 \\
\hline 7 & 6 & 3 & 9 & 12 & 15 & 15 & 30 \\
\hline 8 & 5 & 2 & 7 & 10 & 12 & 12 & 24 \\
\hline 9 & 5 & 2 & 7 & 10 & 12 & 12 & 24 \\
\hline 10 & 5 & 2 & 10 & 10 & 15 & 12 & 27 \\
\hline 11 & 5 & 2 & 5 & 8 & 10 & 10 & 20 \\
\hline 12 & 2 & 3 & 10 & 9 & 12 & 12 & 24 \\
\hline 13 & 1 & 1 & 3 & 5 & 4 & 6 & 10 \\
\hline 14 & 2 & 5 & 12 & 10 & 14 & 15 & 29 \\
\hline 15 & 2 & 5 & 11 & 10 & 13 & 15 & 28 \\
\hline 16 & 4 & 4 & 12 & 10 & 16 & 14 & 30 \\
\hline 17 & 3 & 2 & 32 & 33 & 35 & 35 & 70 \\
\hline 18 & 9 & 2 & 4 & 12 & 13 & 14 & 27 \\
\hline
\end{tabular}

For application names see Appendıx B 2

As defined in Section 3.1.5, residual complexity is based on the notion that the understandability of a software document that can be modeled by a token 
categorization process. In this study the classification schemes considered were based on Halstead's operator-operand token classification. The following three residual complexity classifications schemes were considered for this study:

1. Operator and Operand tokens;

2. Host and Node tokens; and

3. Host Operator, Host Operand, Node Operator, and Node Operand tokens.

Also, as mentioned in Section 3.1.5, after classifying the tokens into ' $\mathrm{q}$ ' equivalence classes, the residual complexity $\mathrm{R}$, is computed as

$$
\mathrm{R}=\mathrm{N}_{1}{ }^{*} \log \left(\mathrm{N}_{1}\right)+\mathrm{N}_{2}{ }^{*} \log \left(\mathrm{N}_{2}\right)+\ldots+\mathrm{N}_{\mathrm{q}}{ }^{*} \log \left(\mathrm{N}_{\mathrm{q}}\right)
$$

where $N_{j}$ is the number of tokens in the jth set for $1<=j<=q$. Two definitions used in this study for $\mathrm{N}_{\mathrm{j}}$ were:

i) count of the number of unique token in equivalence class $\mathrm{j}$; and

ii) count of the total occurrences of tokens in equivalence class $j$.

This spawned 6 sets of measures, two for each of the three classification schemes defined above. Thus, for the kth $(1<=\mathrm{k}<=3)$ classification scheme: two definitions namely $R_{k}$ and $R_{k u n i q}$ were defined, where $R_{k}$ was defined in terms of the total occurrences of tokens, and $\mathrm{R}_{\text {kuniq }}$ was defined in terms of the unique occurrences of tokens.

Since Halstead's basic token counts $\left(\mathrm{n}_{1}, \mathrm{n}_{2}, \mathrm{~N}_{1}, \mathrm{~N}_{2}\right)$ were already measured for each of the application used for the final analysis, they were ported to another directory on a microcomputer, and LOTUS 1-2-3 [LOTUS83] was used to compute the residual complexity by simply embedding the formulas in LOTUS. The resulting residual complexity measures are depicted in TABLE VII. 
TABLE VII

RESIDUAL COMPLEXITY MEASUREMENTS

\begin{tabular}{|c|c|c|c|c|c|c|}
\hline & \multicolumn{2}{|c|}{ Classification I } & \multicolumn{2}{|c|}{ Classification II } & \multicolumn{2}{|c|}{ Classification III } \\
\hline & R1U & R1T & R2U & $\mathrm{R} 2 \mathrm{~T}$ & R3U & R3T \\
\hline 1 & 6871 & 32341 & 6868 & 32070 & 5706 & 28218 \\
\hline 2 & 6074 & 38075 & 6104 & 39015 & 5058 & 34445 \\
\hline 3 & 13058 & 206227 & 13174 & 212173 & 11248 & 192498 \\
\hline 4 & 21974 & 291195 & 21796 & 290787 & 18989 & 264601 \\
\hline 5 & 34445 & 495329 & 34093 & 498931 & 30225 & 456983 \\
\hline 6 & 15361 & 169310 & 15334 & 168250 & 13116 & 152083 \\
\hline 7 & 18865 & 244367 & 18775 & 243058 & 16214 & 220594 \\
\hline 8 & 6868 & 64138 & 6871 & 63905 & 5706 & 56859 \\
\hline 9 & 7837 & 81319 & 7832 & 81312 & 6545 & 72620 \\
\hline 10 & 11400 & 95669 & 11434 & 96089 & 9708 & 86379 \\
\hline 11 & 7688 & 63327 & 7682 & 63046 & 6410 & 56171 \\
\hline 12 & 2967 & 325383 & 20991 & 334935 & 18256 & 305352 \\
\hline 13 & 10061 & 102507 & 10050 & 105249 & 8486 & 94425 \\
\hline 14 & 17629 & 384776 & 17621 & 400418 & 15243 & 365899 \\
\hline 15 & 16788 & 350209 & 16765 & 365378 & 14485 & 333580 \\
\hline 16 & 15179 & 212898 & 15117 & 216044 & 12993 & 195690 \\
\hline 17 & 15194 & 513970 & 15172 & 537973 & 13063 & 493877 \\
\hline 18 & 13463 & 165019 & 13376 & 164701 & 11472 & 148383 \\
\hline
\end{tabular}

For application names see Appendix B 2

Legend R1U, R1T stands for residual complexity measurements calculated for the two cases of Unique and Total occurrences of tokens in the Operator/Operand classification

R2U, R2T same as above except for the tokens in the Host/Node classification

R3U, R3T same as above except for the tokens in the Host Operators, Host Operands, Node Operators and Node Operands, respectively 
Other techniques for collecting static measurement specifically for parallel programs, as discussed in the literature [Zuberek85 and Haban89], were also considered. But those techniques were more detailed and hardware oriented than what was needed for this study, hence they were dropped from further consideration. 


\section{CHAPTER V}

\section{ANALYSIS OF THE MEASUREMENTS}

This chapter describes the methodology used in the analysis of static code measurements including a discussion on inter-metric correlations and correlations among static metrics and the experts' judgements. Also, six models derived based on the experts' perceptions and static metrics are discussed. Tables are used generously to elucidate the discussion. All data analyses were done on the $\mathrm{IBM}^{1}$ mainframe (IBM 3090/200S) [IBM3090-89] using the SAS statistical package [SAS90a]. Standard statistical methods were used (e.g., as described by Conte et al [Conte86]).

\subsection{Choice of a Statistical Test}

In comparison studies especially for small samples and whenever there is any doubt about assumptions, a nonparametric test is found to be more powerful and desirable than a parametric test [Gibbons71]. Conte et al. support Gibbons' statement and add that most nonparametric tests can be applied to data from ordinal scale effectively. Generally, speaking nonparametric statistics require fewer assumptions than their counterpart parametric tests where more restrictions are applied, because nonparametric statistics use the ranks of the observations in the sample and ignore the actual data. One important point to mention is that nonparametric statistics are a kind of transformation, since each measure is transformed into its own rank and hence helps eliminate undesirable outliers.

1 IBM is a registered trademark of International Business Machine Corporation. 
In this study each software complexity metric measures complexity on a potentially different scale and the best way to compare them is by using their ranking in the sample data rather than their actual values.

Selection of a statistical test was not an easy job for this study, as is the case for similar studies such as [Moll89] and [Nandakumar89]. Conover [Conover71] describes it as frustrating, since the process of experimentation does not always lay bare the "truth". He adds that: "One experiment, with one set of observations, may lead two scientists to two different conclusions".

Several nonparametric test such as Friedman, Spearman, and Kendall can be found in the literature (see, e.g., [Conover71], [Daniel78], and [Gibbons71]). The nonparametric statistical test chosen for this study for correlation analysis is the Spearman Rank Correlation Coefficient test. This was done after consulting with Dr. P. Larry Claypool, Professor of Statistics, at Oklahoma State University, and Dr. William L. Woodall, Professor of Statistics, at the University of Alabama. As mentioned in Section 4.2, the choice of this nonparametric test was made especially because of two reasons: first, limited data was available and distributional assumptions, e.g., that a distribution is normal could not be made, for a parametric test; second; the author was interested in checking the monotonicity among the observations and hence among the selected metrics rather than just in checking their linear correlations.

\subsection{Inter-metric Correlations}

Inter-metric correlations using the Spearman Rank Correlation Coefficient statistical test [SAS90b] are included in Appendix G. Variable names used in the correlation coefficient analysis and the variable names used in the regression analysis are included in the Appendix $\mathrm{H}$ with their short descriptions. Some of the 
important correlations within a metric type and among the metrics are discussed below. As a result of these correlations analyses, several interesting points came to surface which are discussed in the following sections.

As explained in Section 3.1.1, the size metric is widely accepted and considered as a basic measure for some models of software development. TABLE VIII represents some of the interesting figures from among the static metric correlations included in Appendix G.

TABLE VIII

EXTRACTED SIZE MEASUREMENTS

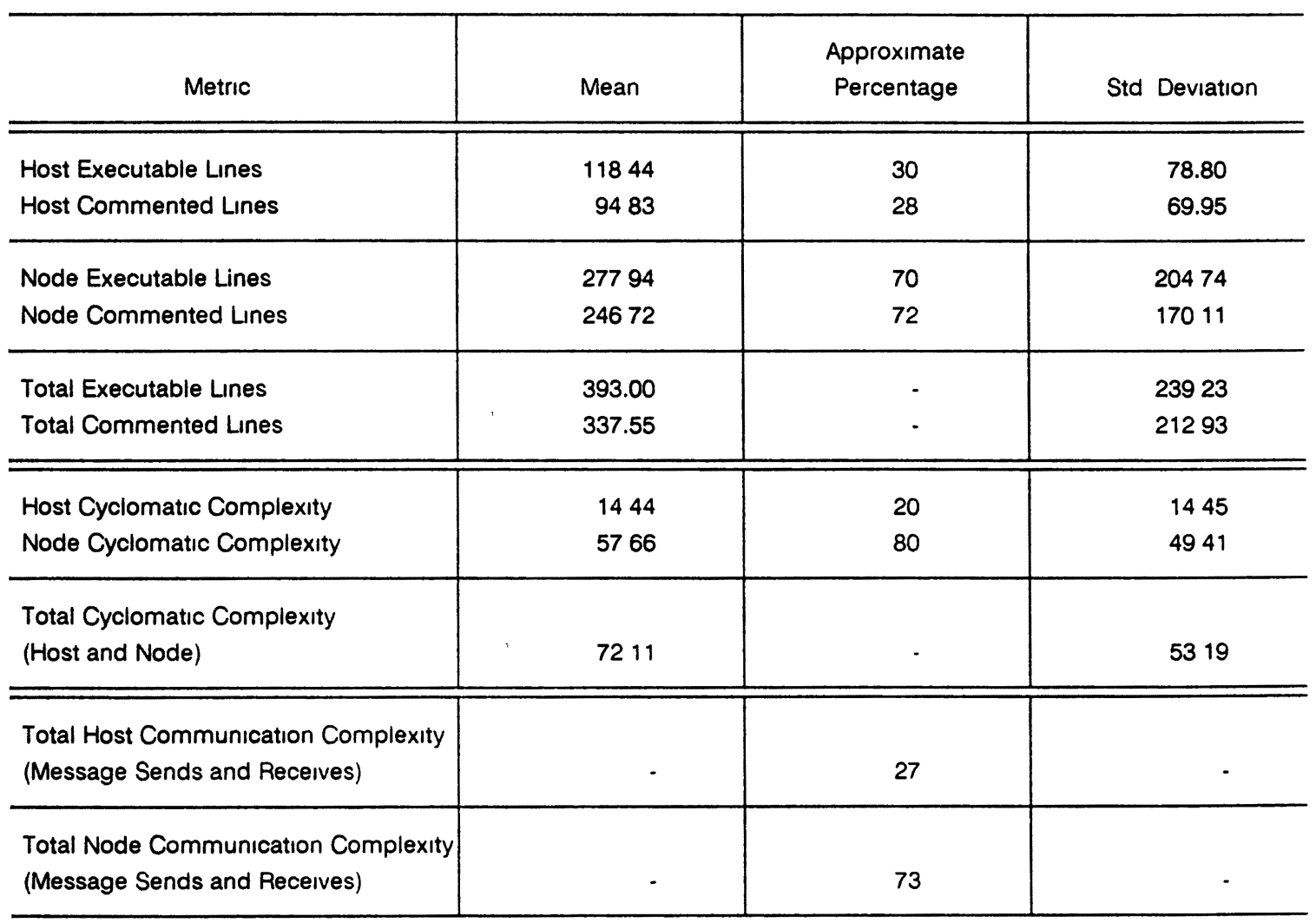

Generally speaking, a host module on a loosely-coupled distributed memory parallel machine (such as the iPSC/2), acts as a driver for an application. It manages the distribution of work for the nodes participating in the execution of an 
application. This fact was supported by this study too. Notice that in the Mean column of TABLE VIII only $30 \%$ of the total executable code belongs to the host modules and the rest belongs to the node modules. Both the host and the node modules were found to be comparably proportional as far as the executable lines of code and the documentation lines are concerned.

An interesting point to mention here is that a host module runs on a single processor whereas a node module runs on several processors. Is it then appropriate to divide $70 \%$ of the code by the total number of nodes that participated in the application execution in order to find out the Mean of the executable lines of code for each node (or processor)? Intuitively speaking, the answer is negative, because a node may be executing only $10 \%$ of the executable code which may consist of a loop statement (such as a 'for' loop that counts numbers from 1 to 1 million), whereas its neighboring node could be doing a relatively simple work such as assigning and initializing a number of variables and that code may be $20 \%$ of the executable code.

Steep standard deviation values of executable code for the host and the node modules are an evidence of variation in their sizes. Correlations between the executable lines of code and the documentation (that is, commented lines) of the host modules were better than the correlations between the executable lines of code and the commented lines of code of the node modules. This could be interpreted as more consistency in the proportion of the executable code and the documentation in the host modules than in the node modules. Strong, positive correlations were found between the host and the node executable lines of code, and Halstead's E of the overall application and the node efforts, respectively, even though the sizes of the modules vary considerably. The significance levels in the above two correlations were less than 0.01

Another interesting point was that even though the Mean executable lines of code of the host was $30 \%$, it contained only $20 \%$ of the cyclomatic complexity. Does 
it mean that the host modules are less complex than the node modules? The answer is affirmative as far as the parallel programs used in this study are concerned. However, more research needs to be done to support the above answer. Strong, positive correlation exist between the executable lines of code of the node modules and the cyclomatic complexity; more so than between the executable lines of code and the cyclomatic complexity of the host modules.

Approximately $27 \%$ of message send or receive statements were found in the host modules and $73 \%$ were found in the node modules. This again supports the general fact regarding distributed-memory parallel machines such as the $\mathrm{iPSC} / 2$, that the host module acts as a driver of an application and the node module do all the complex computations. Another observation is that there was more communication going on among the nodes than between the host and the nodes or vice versa. Relatively weak correlation exist between communication statements and the executable lines of code (mostly at significance levels of 0.05 or less). This was expected, because communication in parallel programs is, in general, independent of the size of a program.

Residual complexity schemes, in which total occurrences of tokens were considered, correlated better with the executable lines of code of the node modules and the overall application's lines of code metrics than when unique occurrences of tokens were considered. On the other hand correlation between the lines of code of the host modules and the residual complexity metrics was higher when unique occurrence of tokens were considered. The significance levels in both cases (unique or total occurrences) was much less than 0.01 .

In Halstead's token count no matter what counting strategy is used, the number of unique operators $\left(\mathrm{n}_{1}\right)$ should be less than or at most equal to the number of unique operands $\left(\mathrm{n}_{2}\right)$ in a source code file (because there can be no operators without at least one operand). This was verified by the operator and operand counts 
for both the host and the node modules. It was noticed that the correlation between the node effort and the total effort was significantly higher than the correlation between the host effort and the total effort, at approximately the same significance levels (less than 0.01). Within the host as well as the node modules, total operators $\left(\mathrm{N}_{1}\right)$ and operands $\left(\mathrm{N}_{2}\right)$ correlate slightly better than the unique operators and operands with the respective efforts of the host or the node modules.

Both the cyclomatic complexity of the node and the host modules correlate positively with their respective effort measurements at significance levels of less than 0.01 . However, correlation between the cyclomatic complexity and the effort of the node modules was stronger than the correlation between the cyclomatic complexity and effort of the host modules.

Residual complexity metrics correlated with Halstead's metrics in the same manner as they correlated with the size metrics described above. Residual complexity schemes, in which total occurrences of tokens were consiclered; correlated better with the node's and each overall application's Software Science metrics than when unique occurrences of tokens were considered. But the Software Science metrics for the host modules correlated better with the residual complexity when unique occurrences of tokens were considered. The significance levels in both cases (unique or total occurrences) was much less than 0.01 .

Weaker correlations were found between the cyclomatic complexity and the communication metrics, suggesting that the two are not dependent on each other (that they measure different dimensions of software complexity). Correlations between the cyclomatic complexity and residual complexity metrics of the host modules were weaker than the correlations between the cyclomatic complexity and residual complexity metrics of the node modules at significance levels of less than 0.05 . This was due to the fact that the node modules have more operators and operands than the host modules. 
The proposed communication metrics were not found to correlate significantly with residual metrics at significance levels of 0.05 , suggesting that the communication metrics are independent of the six token classification measures considered in this study. Residual metric may need to be divided into further classifications, such as the host and the node communication statements, to find better correlations with the communication metrics.

Finally, the six measurements considered for residual complexity metrics were found to correlate to each other strongly and positively at significance levels much less than 0.01 .

\subsection{Analysis of the Subjective Ratings}

As discussed in Section 4.3.1, a questionnaire (Appendix B.1) was devised to correlate the perceived complexity of a number of experts to the five metrics considered in this study. The questionnaire was mailed electronically to the original compiler of the compendium of parallel programs used in this study [Compendium90], Dr. G. B. Lamont of the Air Force Institute of Technology (AFIT). Prior to the design of the questionnaire, the author of this thesis made a personal trip to AFIT in Dayton, Ohio, to discuss several aspects of this study with Dr. Lamont [Lamont90].

A problem had to be resolved after receiving the replies to the questionnaires but prior to the use of the Spearman Rank Correlation Coefficient test. This problem was how to merge the experts' rating of each application in the questionnaire. This issue was solved after consultation with Dr. P. Larry Claypool, Professor of Statistics at Oklahoma State University, by adding the individual ratings for questions 5 through 9 (see Figure 1) in the questionnaire separately. For instance, if the experts' replies to question 5 were $4,4,3$, and 4 , then the total for 
question 5 would be the sum of the above four ratings, that is, 15 . For question 10 (see Figure 1), the ratings were converted into numeric ratings and then added together. Appendix B.2 includes the individual ratings and their sums. As a different approach, accumulated rating could have been divided by the total number of experts who participated in the study in order to normalize the results. But this was avoided because it would not have helped in the analyses and was considered just an extra unnecessary step.

Q \#5 How would you rate the UNDERSTANDABILITY of the HOST program(s) of the following applications on a scale of 1 to 5 ?

(Assume 1 indicates the poorest level and 5 the highest level for questions 5 through 9)

Q \#6. How would you rate the UNDERSTANDABILITY of the NODE program(s) of the following applications on a scale of 1 to 5 ?

Q \#7 How would you rate the documentation of the HOST program(s) of the following applications on a scale of 1 to 5 ?

Q \#8. How would you rate the documentation of the NODE program(s) of the following applications on a scale of 1 to 5 ?

Q \#9 How would you rate the overall perceived or conceptual COMPLEXITY (different from computational complexty) of the following applications on a scale of 1 to 5 ?

Q \#10. If the following applications had been developed as sequential programs, do you think they would have taken less/more/same amount of time and effort? 
Once the above problem was resolved, the Spearman test was applied to find out the correlations between the experts' perceived complexity ratings and the static measurements (Appendix G).

Some of the more important correlations at significance levels of less than or equal to 0.05 are depicted in TABLES IXa through IXf and are discussed below. As mentioned earlier, short descriptions of all the variable names used in the correlations are included in Appendix $\mathrm{H}$.

TABLE IXa

IMPORTANT CORRELATIONS AMONG THE EXPERTS' REPLIES

\begin{tabular}{c|c|c|c|c|c}
\hline & Q5 & Q6 & Q7 & Q8 & Q10 \\
\hline Q5 & 100 & 0.87 & 088 & 091 & 070 \\
\hline Q7 & 088 & 099 & 100 & 0.96 & 091 \\
\hline Q9 & -0.83 & -0.87 & -0.89 & -0.94 & -0.91 \\
\hline
\end{tabular}

This paragraph interprets the correlations shown in TABLE IXa. Strong, positive correlations between questions 5 and 6 , and also between questions 7 and 8 , suggest that the replies were consistent with respect to the understandability and documentation of the host and the node modules. Negative correlations between question 9 and questions 5, 6, 7, and 8 were expected. The reason for the anticipated negative correlations, as discussed in Section 4.3.1, was the nature of the redundancy embedded in the questions asked to compare the consistency in the participants' replies. Strong, negative correlation between questions 9 and 10 suggested that parallel programs with relatively less conceptual complexity might 
have taken relatively more effort if they had been rewritten as sequential programs. This was a surprise to the author too.

TABLES IXb through IXf depict the correlations between the subjective ratings of the perceived complexity of the applications with the five static measurements considered in this study. Weak correlations (weaker than expected) were found at the significance levels of 0.05. Experts' judgements regarding the perceived complexity of the applications correlates better with the executable lines of code of each application than with the total lines of code in the applications. However, the executable lines of code of the node modules correlated better among the three measures shown in TABLE IXb.

TABLE IXb

Q9 VS THE SIZE METRICS

\begin{tabular}{l|c|c|c}
\hline & $\begin{array}{c}\text { Node } \\
\text { Executable Lines }\end{array}$ & $\begin{array}{c}\text { Application } \\
\text { Executable Lines }\end{array}$ & $\begin{array}{c}\text { Total } \\
\text { Lines }\end{array}$ \\
\hline Q9 & 062 & 055 & 050 \\
\hline
\end{tabular}

With Halstead's measurements, question 9 (that is, the experts' perceived complexity rating) correlated with the effort of the overall application quite satisfactorily (TABLE IXc). However, a higher correlation was found between question 9 and the effort of the node modules than the effort of the overall application. Notice that none of the host metrics correlated with the experts' perceived complexity ratings at the significance levels of 0.05 or less (See Appendix G). This was a little unusual and unexpected. 
TABLE IXc

Q9 VS THE SOFTWARE SCIENCE METRICS

\begin{tabular}{c|c|c|c|c|c}
\hline & $\begin{array}{c}\text { Node } \\
\mathrm{n} 1\end{array}$ & $\begin{array}{c}\text { Node } \\
\mathrm{n} 2\end{array}$ & $\begin{array}{c}\text { Node } \\
\mathrm{N} 1\end{array}$ & $\begin{array}{c}\text { Node } \\
\mathrm{N} 2\end{array}$ & $\begin{array}{c}\text { Node } \\
\text { Effort }\end{array}$ \\
\hline $\mathrm{Q} 9$ & 0.56 & 0.53 & 0.67 & 0.70 & 0.72 \\
\hline $\mathrm{Q} 9$ & 0.46 & 0.63 & 0.65 & 0.65 & 0.63 \\
\hline
\end{tabular}

The cyclomatic complexity of the node modules correlated better with question 9 than each overall application's cyclomatic complexity at the significance level of much lesser than 0.05 (TABLE IXd). With the communication metrics, only the message sends metric of the node modules correlated, although weekly, with question 9 at the significance level of less than 0.02 (TABLE IXe). It was also observed that the residual complexity metrics correlated to a fair degree with the perceived complexity. Notice that, at the significance levels of 0.05 or less, only those residual metrics which were based on total occurrences of tokens were adequately correlated to the experts' perceived complexity (TABLE IXf).

\author{
TABLE IXd
}

Q9 VS THE CYCLOMATIC COMPLEXITY METRICS

\begin{tabular}{c|c|c}
\hline & Node $V(G)$ & Application $V(G)$ \\
\hline$Q 9$ & 073 & 0.61 \\
\hline
\end{tabular}


TABLE IXe

Q9 VS THE COMMUNICATION METRICS

\begin{tabular}{c|c}
\hline & Node Message Sends \\
\hline Q9 & 0.57 \\
\hline
\end{tabular}

TABLE IXf

Q9 VS THE RESIDUAL METRICS

\begin{tabular}{l|l|l|l}
\hline & R1T & R2T & R3T \\
\hline Q9 & 065 & 065 & 065 \\
\hline
\end{tabular}

\subsection{Proposed Models}

To study the relationships between the chosen metrics and the experts' perception of relative comprehensibility of parallel programs (question 9), the Stepwise Linear Regression Analysis [SAS90b] was used. For this purpose, six Stepwise Linear Regressions, one against each metric and one by including all possible combinations of five static measures, were run. The following are the resulting six models. For each model presented below, the submetrics chosen were based on the author's intuition and best judgement. Since question 9 represents the perceived complexity by the experts, the acronym PC is used in the following models. In each model, first full model is presented followed by the proposed model. The standard error for each independent variable and residuals for each observation are included in Appendix I. Detalled descriptions of variable names used in the following models are included in Appendix $\mathrm{H}$. 
In the proposed models, all variables left in the models are significant at the 0.15 level, which is also a default level for Stepwise Linear Regressions analysis used in the SAS package. The coefficient values with one standard error are presented in the following format in each model:

$$
\text { (parameter value }{ }^{+} \text {one standard error) }
$$

1. A model considering the size measurements:

Full model:

$$
\begin{aligned}
\mathrm{PC}= & \mathrm{a}_{0}+\mathrm{a}_{1} * \text { HEXELNS }+\mathrm{a}_{2} * \text { HCMTLNS }+\mathrm{a}_{3} * \\
& \text { NEXELNS }+\mathrm{a}_{4} * \text { NCMTLNS }+\mathrm{a}_{5} * \text { TEXELNS }+\mathrm{a}_{6} \\
& * \text { TCMTLNS }+e
\end{aligned}
$$

where e (read as epsilon) stands for residual error.

Proposed model:

$\mathrm{PC}=(8.49 \pm 1.02)+(0.0086 \pm 0.0030) * \mathrm{NEXELNS}+e$

where NEXELNS stands for the executable lines of code of the node modules. The sum of squared residuals is 103.10 and the $\mathrm{R}$-square is equal to 0.33 .

2. A model considering the Software Science measurements:

Full model:

$$
\begin{aligned}
& \mathrm{PC}=\mathrm{a}_{0}+\mathrm{a}_{1} * \text { HUN1 }+\mathrm{a}_{2} * \text { HUN2 }+\mathrm{a}_{3} *+\mathrm{a}_{4} \text { HCAPN1 } \\
& + \text { HCAPN2 }+\mathrm{a}_{5} * \text { HEFRT }+\mathrm{a}_{6} * \text { NUN1 }+\mathrm{a}_{7} \text { * } \\
& \text { NUN2 + } a_{8}^{*} \text { NCAPN1 }+\mathrm{a}_{9}{ }^{*} \mathrm{NCAPN} 2+\mathrm{a}_{10} * \\
& \text { NEFRT }+\mathrm{a}_{11}{ }^{*} \text { TUN1 }+\mathrm{a}_{12} * \text { TUN2 }+\mathrm{a}_{13} * \\
& \text { TUN1N2 }+\mathrm{a}_{14} * \text { TCAPN1 }+\mathrm{a}_{15} * \text { TCAPN2 }+\mathrm{a}_{16} * \\
& \text { TCAPN1N2 }+\mathrm{a}_{17} * \text { TEFRT }+e
\end{aligned}
$$


where $e$ (read as epsilon) stands for residual error.

Proposed model:

$$
\begin{aligned}
\mathrm{PC}= & (5.8 \pm 1.4)+(0.0132 \pm 0.0048) * \mathrm{NCAPN} 1+ \\
& (0.00000141 \pm 0.00000064) * \mathrm{TEFRT}+e
\end{aligned}
$$

where NCAPN1 and TEFRT stand for the total operators of the node module and the overall effort, respectively, of each application. The coefficient of TEFRT has six significant digits after the decimal point, this is because the data was not been normalized (see TABLE IV). The sum of squared residuals is 69.59 and the R-square is equal to 0.55 .

3. A model considering cyclomatic complexity measurements:

Full model:

$$
\begin{aligned}
\text { PC }= & a_{0}+a_{1} * \text { HOSTVG }+a_{2} * \text { NODEVG }+a_{3} * \text { TOTVG } \\
& +e
\end{aligned}
$$

where $e$ (read as epsilon) stands for residual error.

Proposed model:

$\mathrm{PC}=(8.58 \pm 0.86)+(0.04 \pm 0.01) * \mathrm{NODEVG}+e$

where NODEVG stands for the cyclomatic complexity of the node module of each application. The sum of squared residuals is 89.04 and $\mathrm{R}$-square is equal to 0.42 .

4. A model considering the communication complexity measurements: Full model: 


$$
\begin{aligned}
\text { PC }= & a_{0}+a_{1} * \text { HMSGSND }+\mathrm{a}_{2} * \text { HMSGREC }+\mathrm{a}_{3} * \text { NMSGSND } \\
& +\mathrm{a}_{4} * \text { NMSGREC }+\mathrm{a}_{5} * \text { TMSGSND }+\mathrm{a}_{6} * \text { TMSGREC }+ \\
& \mathrm{a}_{7} * \text { TCOMMSG }+e
\end{aligned}
$$

where $e$ (read as epsilon) stands for residual error.

Proposed model:

$\mathrm{PC}=(8.56 \pm 1.02)+(0.262 \pm 0.093) * \mathrm{NMSGSND}+e$

where NMSGSND stands for the message send statements of the node module of each application. The sum of squared residuals is 104.13 and $\mathrm{R}$-square is equal to 0.33 .

5. A model considering the residual complexity measurements:

Full model:

$$
\begin{aligned}
\mathrm{PC}= & \mathrm{a}_{\mathrm{O}}+\mathrm{a}_{1}{ }^{*} \mathrm{R} 1 \mathrm{U}+\mathrm{a}_{2} * \mathrm{R} 1 \mathrm{~T}+\mathrm{a}_{3} * \mathrm{R} 2 \mathrm{U}+\mathrm{a}_{4} * \mathrm{R} 2 \mathrm{U}+ \\
& \mathrm{a}_{5}{ }^{*} \mathrm{R} 3 \mathrm{U}+\mathrm{a}_{6}{ }^{*} \mathrm{R} 3 \mathrm{~T}+e
\end{aligned}
$$

where $e$ (read as epsilon) stands for residual error.

\section{Proposed model:}

$$
\begin{aligned}
\mathrm{PC}= & (4.52 \pm 2.07)-(0.0033 \pm 0.0012) * \mathrm{R} 1 \mathrm{~T}+(0.0238 \pm \\
& 0.0090) * \mathrm{R} 2 \mathrm{~T}-(0.0223 \pm 0.0091) * \mathrm{R} 3 \mathrm{~T}+e
\end{aligned}
$$

where R1T, R2T, and R3T stand for the sizes of classes (in the case where the total occurrences of tokens are considered) in the classifications schemes defined in Section 3.1.4. The sum of squared residual is 61.26 and the R-square is equal to 0.60 .

6. A model considering selected submetrics among the five static measurements: 
Full model:

$$
\begin{aligned}
& \mathrm{PC}=\mathrm{a}_{\mathrm{O}}+\mathrm{a}_{1} * \text { TEXELNS }+\mathrm{a}_{2} * \text { TCMTLNS }+\mathrm{a}_{3}^{*} \\
& \text { TOTLNS }+\mathrm{a}_{4} * \text { TUN1 }+\mathrm{a}_{5} * \text { TUN2 }+\mathrm{a}_{6} * \\
& \text { TUN1N2 }+\mathrm{a}_{7} * \text { TCAPN1 }+\mathrm{a}_{8} * \text { TCAPN2 }+\mathrm{a}_{9} * \\
& \text { TEFRT }+\mathrm{a}_{10} * \text { TOTVG }+\mathrm{a}_{11} * \text { TMSGSND }+\mathrm{a}_{12} * \\
& \text { TMSGREC }+\mathrm{a}_{13} * \text { TCOMMSG }+\mathrm{a}_{14} * \mathrm{R} 1 \mathrm{U}+\mathrm{a}_{15} \text { * } \\
& \mathrm{R} 1 \mathrm{~T}+\mathrm{a}_{16}{ }^{*} \mathrm{R} 2 \mathrm{U}+\mathrm{a}_{17}{ }^{*} \mathrm{R} 2 \mathrm{~T}+\mathrm{a}_{18}{ }^{*} \mathrm{R} 3 \mathrm{U}+\mathrm{a}_{19} \text { * } \\
& \mathrm{R} 3 \mathrm{~T}+e
\end{aligned}
$$

where $e$ (read as epsilon) stands for residual error.

\section{Proposed model:}

$$
\begin{aligned}
\mathrm{PC}= & (4.9 \pm 1.4)+(0.037 \pm 0.0114) * \mathrm{TCAPN} 2+(0.182 \pm \\
& 0.105)+{ }^{*} \mathrm{TMSGSND}-(0.00118 \pm 0.00396) * \mathrm{R} 1 \mathrm{~T}+e
\end{aligned}
$$

where TCAPN2 stands for the total operands in each application, TMSGSND stands for the total message send statements in each application, and R1T stands for the residual complexity calculated for the case of total occurrences of token when tokens were classified as operators and operands. The sum of squared residuals is 58.37 and the $\mathrm{R}$-square is equal to 0.62 .

The R-square value (Appendix I), also called the coefficient of determination, is the square of the correlation between dependent variables and the predicted values. The significance probability, Prob $>F$ (Appendix I), is the probability of getting a greater $\mathrm{F}$ statistic [SAS90b] than that observed if the hypothesis is true. The steady increase of the R-square value in the Stepwise Regression Analysis indicates the appropriateness of the models presented. 
Another sign of the appropriateness of the above six models is the significance probability, i.e., the Prob $>\mathrm{F}$ levels, which in these cases are much less than 0.01 . Notice that almost all the models are heavily dependent on the nodes' tokens. The intercept and other coefficients' values are given in Appendix I.

Other statistical methods such as Nonlinear Regression Analysis [SAS90b] were considered for this study. However because of the small sample size it was decided that the results of these methods would not be very reliable. 


\section{CHAPTER VI}

\section{EPILOGUE AND FUTURE WORK}

There are many ways to measure the performance of a parallel system. Several studies conducted by the researchers [Zuberek85, Haban89, and Karp90] are mostly from the hardware point of view measuring, among other things, the inter-processor communication or parallel processors performance. This author found a lack of literature discussing the relationship between conceptual complexity and structural complexity of parallel programs and hence decided to explore this area.

Before discussing the conclusions, two points need to be mentioned: 1) since this was the first study of its kind, the conclusions of this study should be interpreted as observations, and 2) the final analysis and the proposed models should be construed as general templates for hypotheses in future studies.

On the average, $20 \%$ of the cyclomatic complexity and $27 \%$ of the communication complexity were found in the host module that had an average $30 \%$ of the executable lines of code of the applications considered in this study. This was expected, as the host modules are generally considered as drivers of applications and are relatively less complex than their counterpart, the node modules. Another reason why the host module carries less percentage of the code is the fact that the host program runs on a single processor whereas the node module splits the code among several processors on a parallel machine such as iPSC/2.

In this study five sets of metrics were investigated including the proposed communication metrics. Almost all five static metrics, at different significance 
levels, were found to be strongly correlated to each other. This supports the use of the metrics, which were originally proposed for sequential programs, to measure the structural complexity of parallel programs.

Residual complexity, that attempts to quantify the understanding process of a software document by dividing it into different classes of tokens, correlates strongly and positively with the size metric. However, residual complexity correlates better when the classifications are based on the total occurrences of tokens as opposed to the classifications based on the set of unique tokens. To get higher correlations with residual complexity, further token classifications need to be described.

Weaker correlation between the cyclomatic complexity and the communication metrics suggested that the two are not directly dependent on each other and perhaps they measure different dimensions of the structural complexity of software. The same situation was found in the cases of correlations between the cyclomatic complexity and the communication complexity with residual complexity metrics.

It is evident from the data that there is very little discrimination among the experts' replies. For instance, consider the replies number 1 through 11 (Appendix B.2), the total number of participants who replied to question 5 (column labeled "Q5") is 14. This predicts that either the question was too general, i.e., it was not specific enough so that a participant could reply differently or the sample data was too little to obtain some reliable Stepwise Regression analysis and hence present a meaningful model.

The R-square (or coefficient of determination) and the significance probability (Prob $>\mathrm{F}$ levels) are the two major values to be considered to probe the healthiness of a model. The six models presented in Section 5.4 showed the significance probabilities less than 0.01 . The R-square values for the models varied between good to moderate, as the models accounted for the variation from 
approximately $62 \%$ to $32 \%$. As explained earlier, since the sample size was small, these models may not represent truly their respective populations. The models given in Section 5.4 provide a reasonable approximation that could be considered as hypotheses for future research and tested empirically on a larger set of programs and/or with a larger population of participants with varying levels of expertise.

The compendium of parallel programs used in this study has lot to be explored (either as future work related to this thesis or unrelated to this thesis).

This study was specific to parallel programs written on Intel iPSC family of concurrent supercomputers. Future studies may address some of the issues that were not discussed in this study. An issue that can be investigated is to find out the distribution of the code that resides on the node modules among the nodes participating in the execution of an application. Another topic for future study is to consider the programs that belong to some specific categories, such as sorting or simulation programs, and find out which program is an optimal solution to the problem (in terms of being least complex) and why, or what is the optimal size of a sorting program. Other future work may involve the comparison or correlation of the growth of the host modules and/or node modules with respect to complexity metrics. Also more refined and/or different classification schemes for residual complexity metrics could be defined to find better correlations between residual complexity metrics and perceived complexity. Programs in the compendium could also be used to evaluate the effort needed to write the same application on other parallel machines such as the Sequent [Sequent89], a tightly-coupled, sharedmemory parallel machine. Control flow in the parallel program using graph theory could also be constructed and quantified to be compared with other structural metrics. 


\section{REFERENCES}

[Basili86]

V. R. Basili, R. W. Selby, and D. H. Hutchens, "Experimentation in Software

Engineering," IEEE Trans. Software Eng., vol. SE-12, pp. 733-743, July 1986.

[BBN89]

BBN Advanced Computers Inc., Cambridge, MA, 1989.

[Bishop87]

M. Bishop, "Profiling under UNIX by Patching," Software--Practice \& Experience, vol. 17, pp. 729-739, Oct. 1987.

[Boehm81]

B. W. Boehm, Software Engineering Economics, Prentice-Hall, Englewood Cliffs, NJ, 1981.

[Close88]

Paul Close, "The iPSC/2 Node Architecture," The Third Conference on Hypercube Concurrent Computers and Applications, Pasadena, California, vol. I, pp. 43-50, January 1988.

[Compendium90]

G. B. Lamont and R. A. Beard, Compendium of Parallel Programs for the Intel iPSC Computers, vol. 1,2,3, ver. 1.4, Dept. of Electrical and Comp. Eng., School of Eng., Air Force Inst. of Tech., Wright-Patterson AFB, Dayton, OH, October 1990.

[Conover71]

W. J. Conover, Practical Nonparametric Statistics, John Wiley \& Sons Inc., New York, NY, 1971.

[Conte86]

S. D. Conte, H. E. Dunsmore, and V. Y. Shen, Software Engineering Metrics and Models, Bengamin/Cummings, Menlo Park, CA, 1986.

[Daniel78]

W. W. Daniel, Applied Nonparametric Statistics, Houghton Mifflin Company, Boston, MA, 1978.

[DOS87]

International Business Machines Corporation, P.O. Box 1328-W, Boca Raton, FL, 1987.

[Encore89]

Encore Computer, Marlborough, MA, 1989. 
[Fox88]

G. Fox, M. Johnson, G. Lyzenga, S. Otto, J. Salmon, and D. Walker, Solving Problems on Concurrent Processors, vol. I, Prentice-Hall, Englewood Cliffs, NJ, 1988.

[Gibbons71]

J. D. Gibbons, Nonparametric Statistical Inference, McGraw-Hill Book Company, New York, NY, 1971.

[Goldberg86]

R. Goldberg, "Software Engineering: An Emerging Discipline," IBM Syst. J., vol. 25 , nos. 3 \& 4, pp. 334-353, 1986.

[Graham83]

S. L. Graham, P. B. Kessler, and M. K. McKusick, "An Execution Profiler for Modular Programs," Software--Practice \& Experience, vol. 13, pp. 671-685, 1983.

[Green89]

Green Hills Software, Inc., iPSC/2 - C Language Reference Manual, Green Hills Software, Inc., CA, 1989.

[Haban89]

D. Haban and D. Wybranietz, "Monitoring and Measuring Parallel Systems Using a Non-Intrusive, Rule-Based Evaluation System," Technical Report TR-88-007, ICSI, Berkeley, CA, March 1989.

[Halstead77]

M. H. Halstead, Elements of Software Science, Elsevier Nort-Holland, Inc.,

New York, NY, 1977.

[Hayes88]

J. P. Hayes, Computer Architecture and Organization, McGraw-Hill Inc., New York, NY, 1988.

[Henry79]

S. M. Henry, "Information Flow Metrics for the Evaluation of Operating Systems' Structure," Ph.D Dissertation, Iowa State Univ., Ames, IA, 1979.

[IBM3090-89]

"3090 Processors Complex - Functional Characteristics," International Business Machine Corporation, Publication number SA22-7121-8, Seventh Edition, Poughkeepsie, NY, 1989.

[Intel88]

Intel Scientific Computers, Beaverton, Oregon, 1988.

[iPSC88]

The iPSC/2 User's Guide, Intel Scientific Computers, Beaverton, OR, 1988.

[Karp90]

A. H. Karp and H. P. Flatt, "Measuring Parallel Processor Performance," Communications of the ACM, vol. 33, no. 5, pp. 539-543, May 1990. 
[Kernighan78]

B. W. Kernighan and D. M. Ritchie, The C Programming Language, PrenticeHall, Englewood Cliffs, NJ, 1978.

[Lamont90]

G. B. Lamont, Private Communication, Dept. of Electrical and Comp. Eng., School of Eng., Air Force Inst. of Tech., Wright-Patterson AFB, Dayton, OH, October 1990.

[LOTUS83]

Lotus Development Corporation, User's Manual, Release 2, 161 First Street, MA, 1983.

[McCabe76]

T. J. McCabe, "A Complexity Measure," IEEE Trans. Software Eng., vol. SE-2, pp. 308-320, December 1976.

[Moll89]

K. E. Moll and M. H. Samadzadeh, "An Empirical Study of the Relationship Between Static Software Complexity Metrics and Dynamic Measurements of Pascal and C Programs," Proceedings of the 1989 ACM South Central Regional Conference, Tulsa, OK, pp. 150-157, November 1989.

[Nandakumar89]

C. K. Nandakumar, "Quantifying the Software Maintenance Task: An Empirical Study of Complexity Metrics Across Versions," Masters Thesis, Computer Science Department, Oklahoma State University, Stillwater, OK, May 1989.

[Nugent88]

S. F. Nugent, "The iPSC/2 Direct-Connect Communications Technology," The Third Conference on Hypercube Concurrent Computers and Applications,

Pasadena, CA, vol. I, pp. 51-60, January 1988.

[PCMETRIC90]

Set Laboratories, Inc., PC-METRIC, ver. 1.0, Mulino, OR, 1990.

[Pierce88]

Paul Pierce, "The NX/2 Operating System," The Third Conference on Hypercube Concurrent Computers and Applications, Pasadena, CA, vol. I, pp. 384-390, January 1988.

[Rattner85]

J. Rattner, "Concurrent Processing: A New Direction in Scientific Computing," AFIPS Conference Proceedings, Chicago, IL, vol. 54, pp. 157-166, July 1985.

[Samadzadeh88]

M. H. Samadzadeh and W. R. Edwards, Jr., "A Classification Model of Software Comprehension," 21st Hawaii Int. Conf. on System Sciences (HICSS21), HI, 1988. 
[Sequent89]

Sequent Computer System, Inc., "Guide to Parallel Programming - On Sequent Computer Systems," Editor: Anita Osterhaug, Printice-Hall, Englewood Cliffs, NJ, 1989.

[SAS90a]

SAS/STAT User's Guide, ver. 6, Fourth Edition, vol. 1, SAS Inst., Cary, NC, 1990.

[SAS90b]

SAS/STAT User's Guide, ver. 6, Fourth Edition, vol. 2, SAS Inst., Cary, NC, 1990.

[Seitz85]

C. L. Seitz, "The Cosmic Cube," Communications of the ACM, vol. 28, no. 1, pp. 22-33, January 1985.

[Stone87]

H. S. Stone, High-Performance Computer Architecture, Addison-Wesley Publishing Company, Reading, MA, 1987.

[UNIX86]

The UNIX System V User's Manual, AT\&T, Prentice-Hall, Englewood Cliffs, NJ, 1986.

[Zuberek85]

W. M. Zuberek, "Performance Evaluation of Concurrent Systems Using Timed Petri Nets," Proc. ACM Computer Science Conference, Denver, CO, pp. 326-329, March 1985. 
APPENDICES 
APPENDIX A

A SAMPLE PROGRAM 


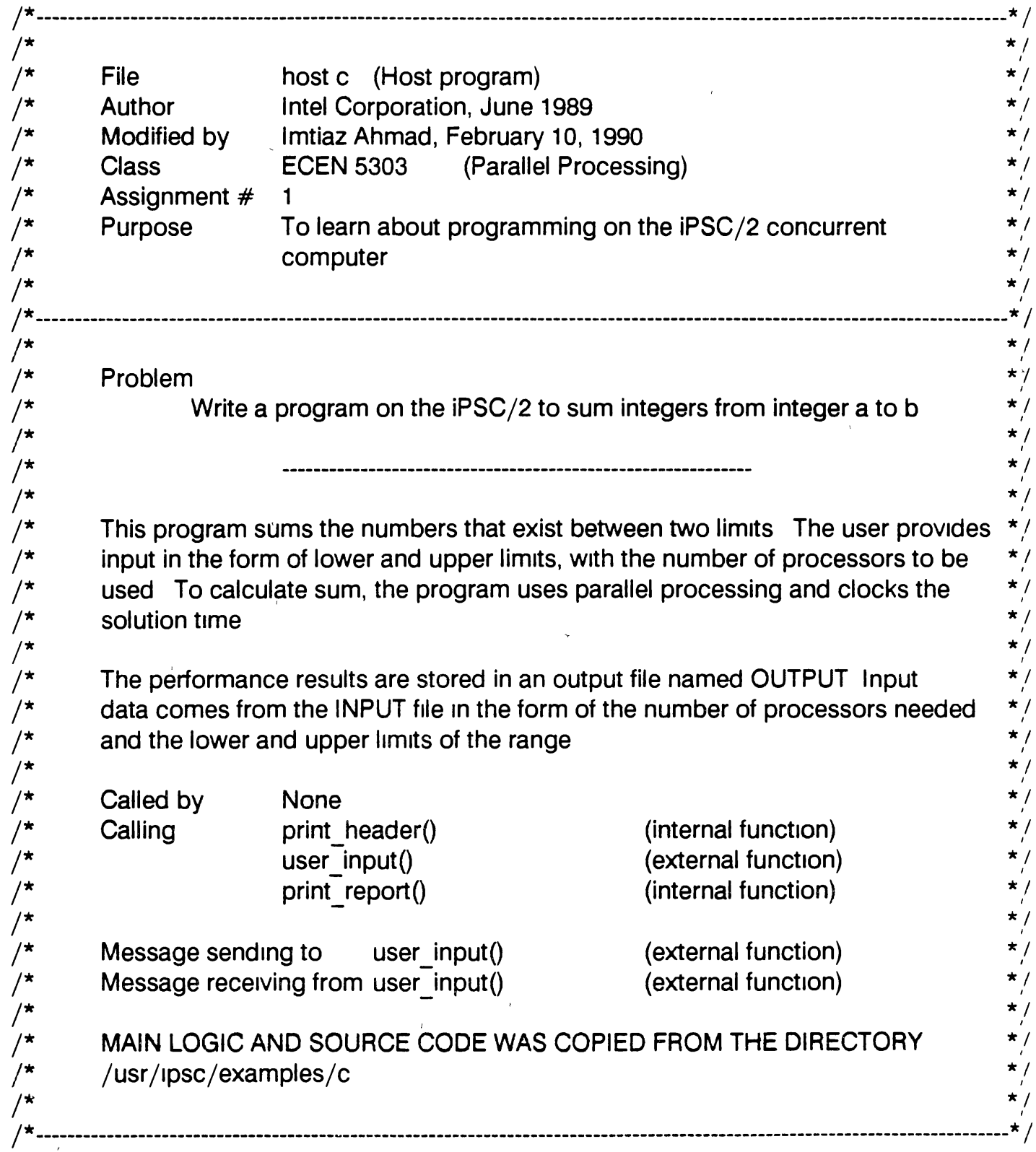

\#include <stdio h> \#include <cube h>

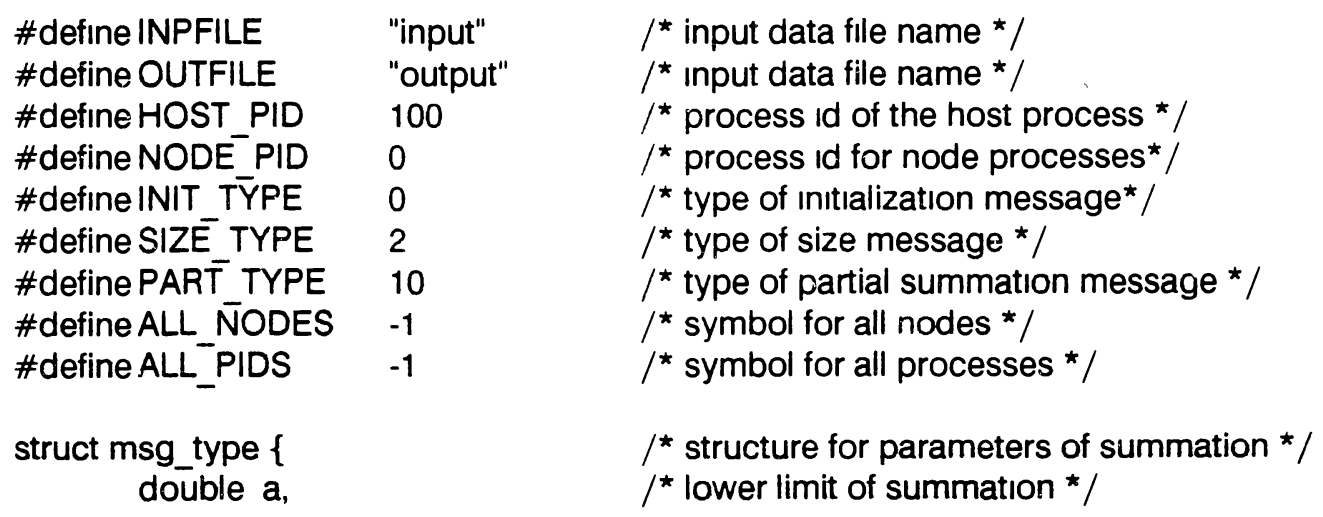




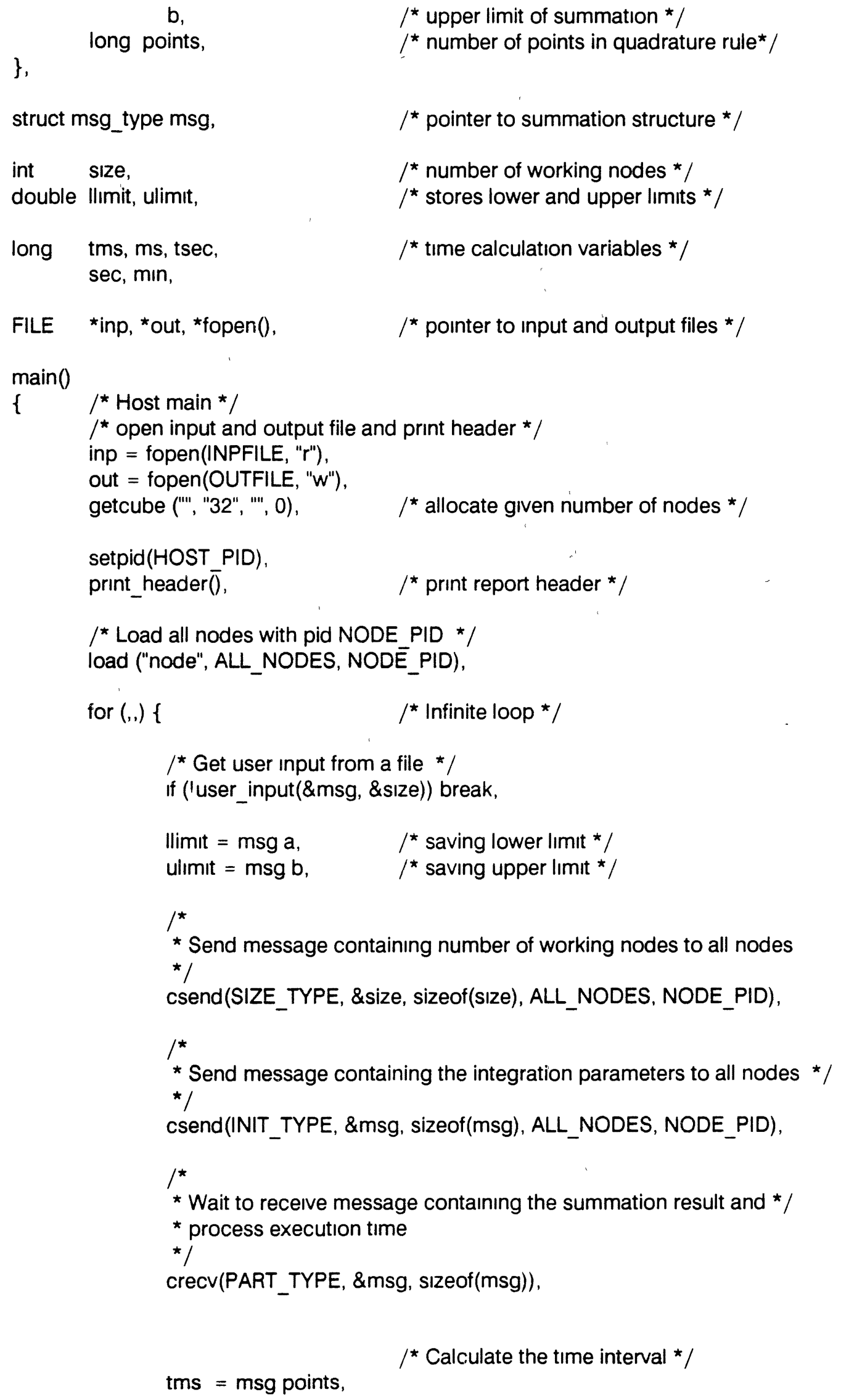




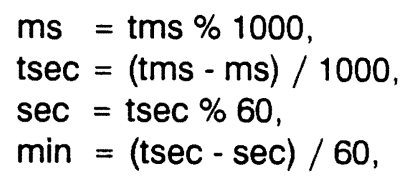

print_report(size, llimit, ulimit, msg.b, min, sec, ms, msg a),

\} $/{ }^{*}$ End infinite loop */

killcube(ALL_NODES, ALL_PIDS),

relcube(),

$/{ }^{\star}$ release attached cube ${ }^{\star} /$

close (Inp, out),

printf("Normal terminatıon of the program $\backslash n$ "),

\} / End host main */

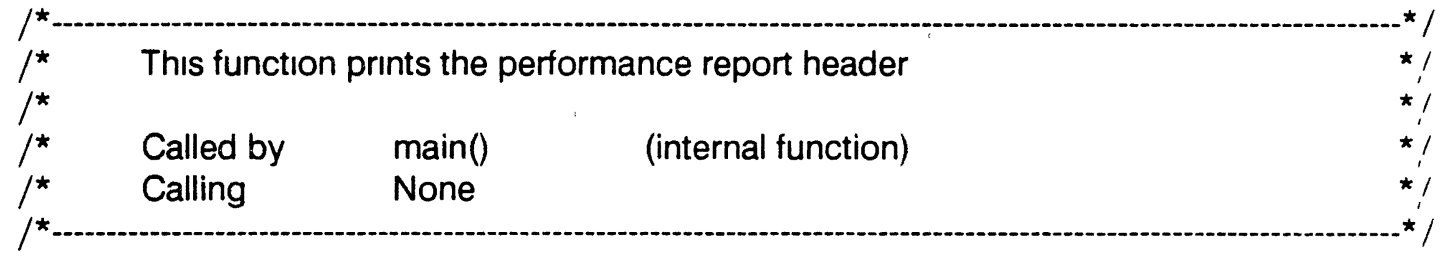

print_header()

\{

fprintf(out, " $\backslash t$ Following is the performance report for the given data $\backslash n$ "),

fprintf(out, " $\backslash \mathrm{t}$ $-\backslash n ")$,

fprintf(out, "\# of Lower Upper Basıc Elapsed-Time $\backslash n$ "),

fprintf(out, "pres limit limit Range slices min sec ms SUM $\backslash n$ "),

\}

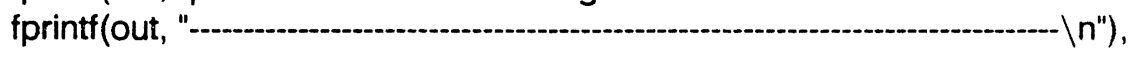

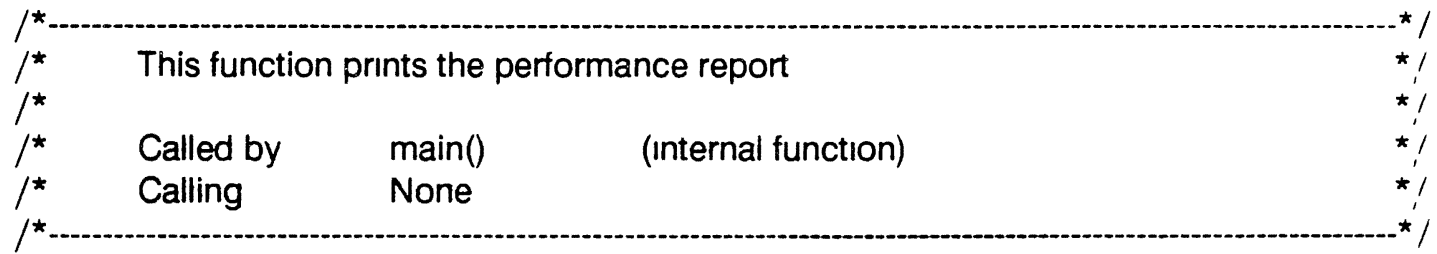

print_report(sIz, llim, ulım, bs, $m$, se, ms, tot)

int ${ }^{\star}$ siz,

double llim, ulim, bs, tot,

long $\mathrm{m}$, se, $\mathrm{ms}$,

\{

double lim,

$\lim =$ ulim $-\lim +1$

fprintf(out, "\%3d \%6 of $\% 11$ of $\% 11$ of $\% 11$ of $\% 3 l d \% 3 l d \% 4 l d \% 20$ of $\backslash n$ ", siz, llım, ulim, lım, bs, $m$, se, ms, tot);

\} 


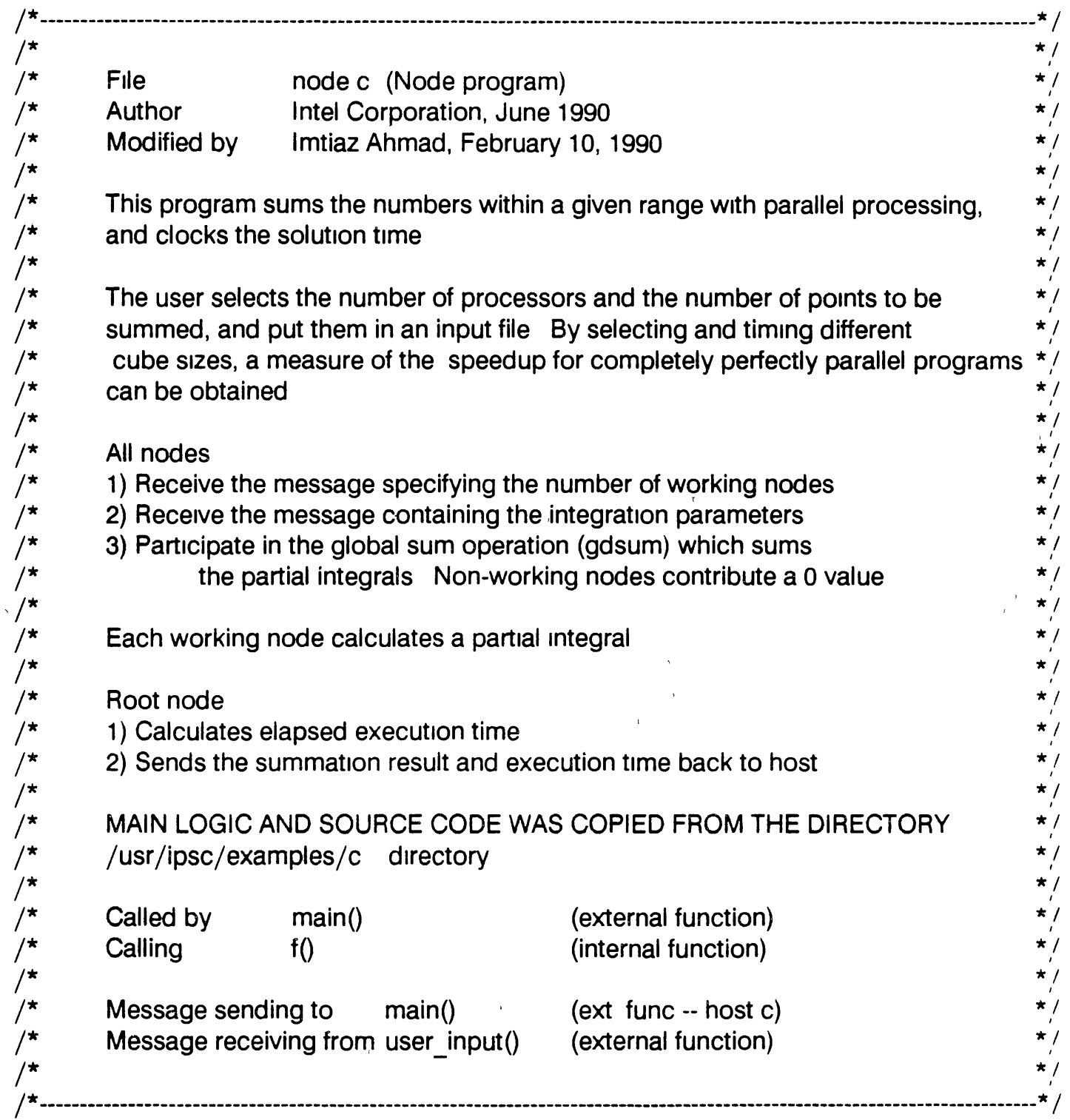

\#include <cube $\mathrm{h}>$

\begin{tabular}{|c|c|c|}
\hline $\begin{array}{l}\text { \#define HOST PID } \\
\text { \#define INIT TYPE } \\
\text { \#define SIZE- TYPE } \\
\text { \#define PART' TYPE } \\
\text { \#define ROOT }\end{array}$ & $\begin{array}{l}100 \\
0 \\
2 \\
10 \\
0\end{array}$ & $\begin{array}{l}/^{*} \text { process id of the host process } * / \\
/^{*} \text { type of initialization message } * / \\
/^{*} \text { type of size message }{ }^{*} / \\
/^{*} \text { type of partial sum message } * / \\
/^{*} \text { root node id }{ }^{*} /\end{array}$ \\
\hline $\begin{array}{l}\text { int work_nodes, } \\
\text { my_pid, } \\
\text { my_node, }\end{array}$ & & $\begin{array}{l}/{ }^{*} \text { number of nodes which will work on problem */ } \\
/{ }^{*} \text { process id of the nodes }{ }^{*} / \\
/^{*} \text { node id of each node }{ }^{*} /\end{array}$ \\
\hline $\begin{array}{l}\text { long } \mathrm{m} \text {, } \\
\text { extra_slices, } \\
\text { starttime, }\end{array}$ & & $\begin{array}{l}/^{*} \text { minınum number of slices to be given each node } * / \\
/^{*} \text { remainder of the range after even distribution } * / \\
/{ }^{*} \text { start time of calculation } * /\end{array}$ \\
\hline parti & & /* holds partial sum * / \\
\hline
\end{tabular}


work,

my_a,

my_b,

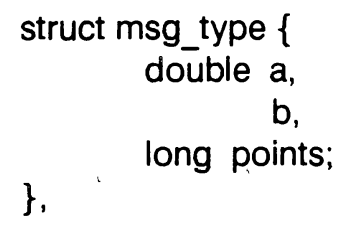

struct msg_type sum,

main()

$\{\quad / *$ node main * $/$

long $f()$;

int $j$,

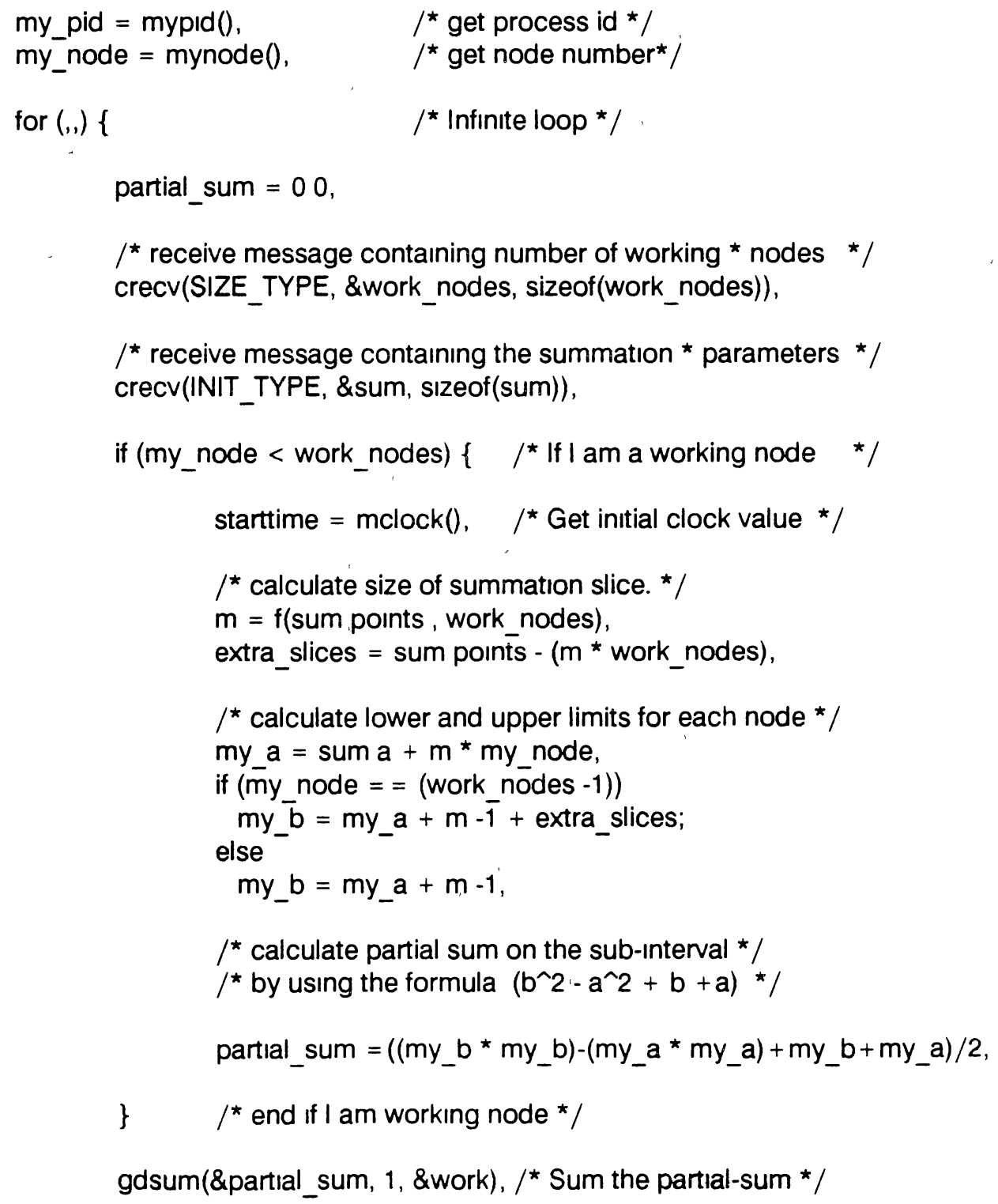


${ }^{*}$ If I am the root node, calculate the elapsed tıme and

* send the summed partial sum and the time to the host * /

If (mynode ()$==$ ROOT) \{

$$
\begin{aligned}
& \text { sum } a=\text { partial_sum, } \\
& \text { sum. } b=m,
\end{aligned}
$$$$
\text { sum points }=\text { mclock }()-\text { starttıme, }
$$

\}

csend(PART_TYPE, \&sum, sizeof(sum), myhost(), HOST_PID),

\} / End Infinite loop */

\} $/ *$ End node main * $/$

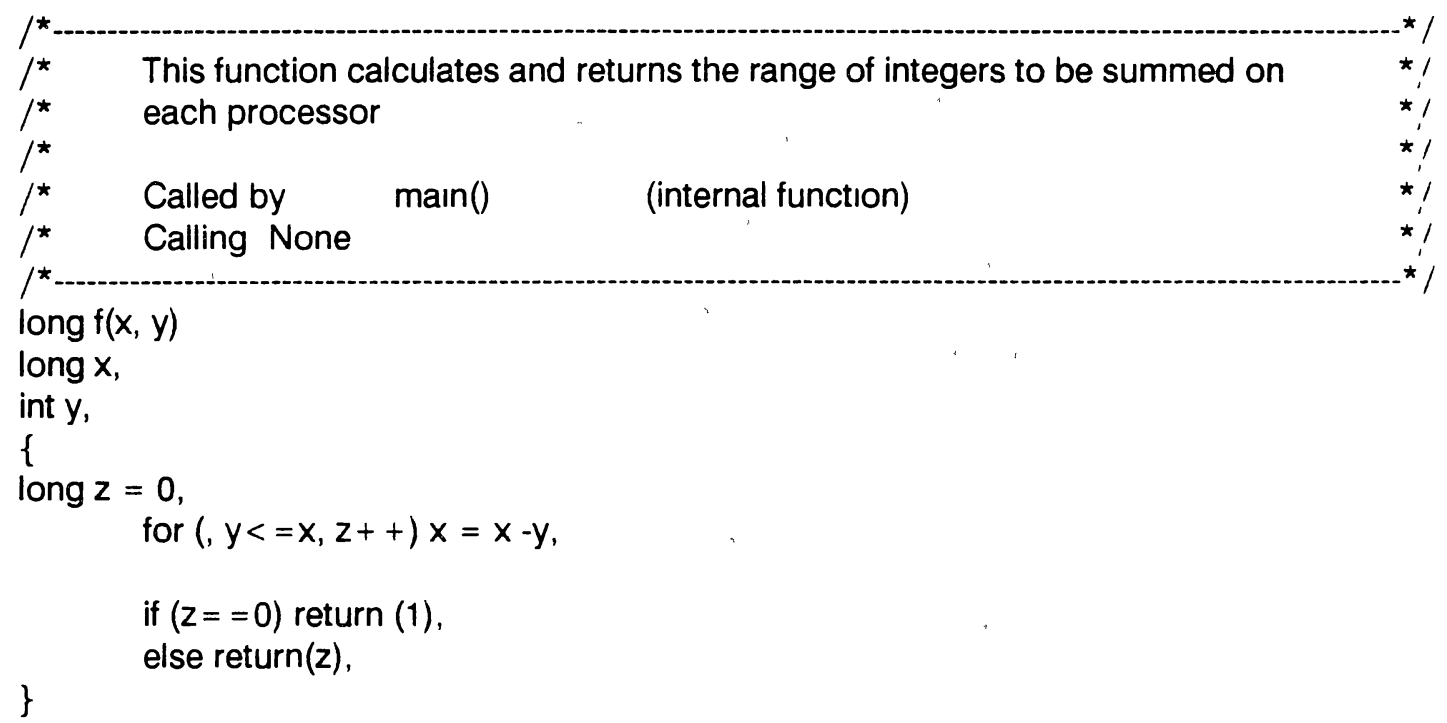

Example Source code of the example given in Section 23 
APPENDIX B

THE QUESTIONNAIRE AND THE EXPERTS' REPLIES 


\title{
APPENDIX B.1: DETAILED QUESTIONNAIRE
}

\author{
MASTERS THESIS RESEARCH \\ QUESTIONNAIRE
}

Dear Participant

I am a Masters student at Oklahoma State University (OSU) and I am currently doing my thesis on "Software Metrics for Parallel Programs". Would you please take a few minutes to help me with my research by filling out and returning the following questionnaire Your participation is voluntary.

Thank you

\section{SUBJECTIVE EVALUATION OF PARALLEL PROGRAMS \\ DEVELOPED ON THE IPSC FAMILY OF COMPUTERS}

This questionnaire will take about 10 minutes to complete No detailed answers are required. After completing the questionnaire, kindly mail it to me (e-mail or US mail) Please try to fill out and return the questionnaire to me within one week Your help is extremely appreciated

Graduate Student Name: Office Address.

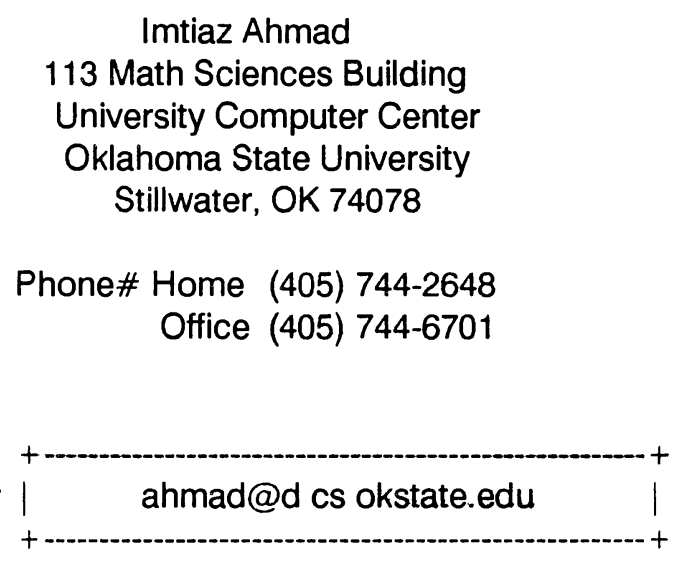

Imtiaz Ahmad

113 Math Sciences Building

University Computer Center

klahoma State University

Stillwater, OK 74078

Office (405) 744-6701

This questionnaire is designed for experts who are well versed in parallel programming theoretically or have had sufficient hands-on experience in parallel programming, so that they can subjectively evaluate parallel programs developed for Intel's iPSC/ 1 or iPSC/ 2 concurrent computer. While answering the questions, please feel free to add any comments that you might have Also, if you do not wish to answer a question, please leave it blank or, if possible, contact me by telephone or through e-mail for clarification All questions could be answered by marking the given spaces (dashed lines) by any character such as " $x$ "

The term UNDERSTANDABILITY, which is used in this questionnaire is defined below

Code possesses the characteristic understandability to the extent that its purpose is clear to the inspector This implies that variable names or symbols are used consistently, modules of code are self-descriptive, and the control structure is simple or in accordance with a prescribed standard 
Questions 1 through 4 assess the expertise level of the person who is evaluating the applications (i e , programs) considered in this study

Q \#1 Highest academic degree

Q \#2 Experience in computer programming

$\begin{array}{lll}\text { less than } & \text { - }-5 \text { years } & \begin{array}{l}\text { more than } \\ 2 \text { years }\end{array} \\ \end{array}$

Q \#3: Experience (hardware and/or software) in parallel processing:

$\begin{array}{lll}\text { less than } & 2-5 \text { years } & \text { more than } \\ 2 \text { years } & & 5 \text { years }\end{array}$

Q \#4 Experience (hardware and/or software) with Intel's iPSC family of computers (iPSC/ 1 and IPSC/2)

$\begin{array}{lll}\text { less than } & 1-2 \text { years } & \begin{array}{l}\text { more than } \\ 1 \text { year }\end{array} \\ \end{array}$

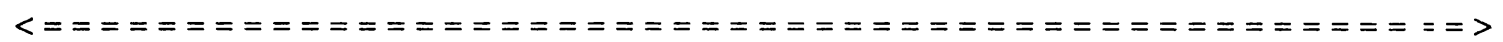

In questions 5 through 9 below please rate the 37 applications (or THE ONES THAT YOU ARE FAMILIAR WITH) used in this study. IF YOU ARE NOT FAMILIAR WITH AN APPLICATION, PLEASE LEAVE IT BLANK

All the applications reside under the "tex/programs" directory of the compendium except the last one which resides in the "tex/compendium" directory. This collection of application programs were made available to me by 'Dr Lamont of the Air Force Institute of Technology, Dayton, Ohio The directory paths shown below represent the application category, author(si) name, etc. The appropriate machine name is also given in front of each application's path

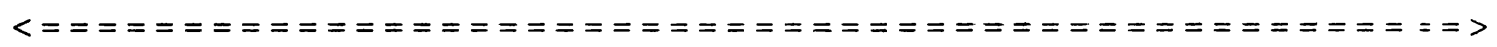

Q \#5 How would you rate the UNDERSTANDABILITY of the HOST program(s) of the following applications on a scale of 1 to 5 ?

Assume 1 indicates the poorest level and 5 the highest level of understandability

rings/beard

rings/huson/c .

rings/proicou

meshs/beard .

meshs/fife

meshs/harding .

meshs/huson

meshs/proicou

sorts/Beard

sorts/Beard Koch/cube386 .

sorts/Beard_Koch/mem_cube

sorts/Fife_Proicou/cubē386

\begin{tabular}{|c|c|c|c|c|c|}
\hline (iPSC/1) & $1--$ & --- & --- & --- & --.5 \\
\hline$(\mathrm{IPSC} / 1)$ & $1--$ & --. & -- & -- & --.5 \\
\hline (iPSC/1) & $1--$ & --- & --- & --- & --.5 \\
\hline (iPSC/1) & $1--$ & --- & --- & -- & --.5 \\
\hline$(\mathrm{IPSC} / 1)$ & 1--- & --- & -- & --- &.--5 \\
\hline$(\mathrm{IPSC} / 1)$ & 1--- & --- & --- & --- & --5 \\
\hline (iPSC/1) & 1--- & --- & --- & --- & $\ldots-5$ \\
\hline$(\mathrm{IPSC} / 1)$ & 1-- & -.- & --. & -.- & ---5 \\
\hline (iPSC $/ 1)$ & $1 \cdots$ & -.- & -.. & -.. & --5 \\
\hline$(\mathrm{IPSC} / 2)$ & $1--$ & --- & $-\cdots$ & --- &.--5 \\
\hline (iPSC/1) & $1-$ & -- & -- & -- & ---5 \\
\hline (iPSC/2) & 1--- & --- & --. & --- & --.5 \\
\hline
\end{tabular}


sorts/Fife Proicou/mem cube sorts/Harding_Rottman/cube386 sorts/Harding_Rottman/mem_cube sorts/Huson .

heaps/Beard Koch/cube386 heaps/Beard Koch/mem cube heaps/Fife Proicou/cubē̄o 86 heaps/Fife-Prolcou/mem cube heaps/Harding Rottman/cube386 heaps/Harding_Rottman/mem_cube heaps/Huson projects/NeuralNets/conway projects/NeuralNets/simmers projects/TSP/rottman . projects/TSP/sawyer projects/beard/src/Thesis/parallel projects/beard/src/Thesis/serial projects/beard/src/Version1 projects/fife/src projects/harding projects/huson/src/new_stuff projects/koch/src projects/proicou/dinephil1 projects/proicou/dinephil2 .

\begin{tabular}{|c|c|c|c|c|c|}
\hline (iPSC/1) & 1--- & --- & -- & --- & ---5 \\
\hline (iPSC/2) & 1--- & --- & -- & --- & ---5 \\
\hline (iPSC/1) & 1-.. & --- & --. & -.- & --5 \\
\hline (iPSC/1) & 1--. & --- & --- & --- & --.5 \\
\hline (iPSC/2) & 1--- & --- & --- & -- & --5 \\
\hline (iPSC/1) & 1--- & -- & -- & --- & ---5 \\
\hline (iPSC/2) & 1-- & --- & --- & --- & ---5 \\
\hline (iPSC/1) & 1--- & --- & --- & --- & ---5 \\
\hline (iPSC/2) & 1--- & -- & --- & --- & ---5 \\
\hline (iPSC/1) & 1--- & --- & -- & --- &.- .5 \\
\hline (iPSC/1) & $1--$ & --- & -- & --- & ---5 \\
\hline (iPSC/1) & 1-- & -- & -- & --- & ---5 \\
\hline (iPSC/1) & $1--$ & --- & -- & --- & ---5 \\
\hline (iPSC/1) & 1--. & --- & -.. & --- & --5 \\
\hline (iPSC/1) & 1-.. & -.- & ... & --- & --.5 \\
\hline (iPSC/2) & 1--- & --- & -- & --- & ---5 \\
\hline (iPSC/2) & 1--- & --- & --- & --- & --5 \\
\hline (iPSC/2) & 1--- & --- & --- & --- & ---5 \\
\hline (iPSC/1) & 1--- & -- & $\cdots$ & --- & --5 \\
\hline (iPSC/1) & $1-\ldots$ & --- & $\cdots$ & --- & $\ldots-5$ \\
\hline (iPSC/1) & $1 \ldots$ & --- & --- & --- & ---5 \\
\hline (iPSC/1) & $1 \ldots$ &.-- & -- & --- & ---5 \\
\hline (iPSC/1) & $1--$ & -- & -- & --- & --5 \\
\hline (iPSC/1) & 1--- & --- & --- & -.- &.- .5 \\
\hline (iPSC/2) & 1--- & --- & -.- & --- & $\ldots-5$ \\
\hline
\end{tabular}
tex/compendium/projects/SCPArchive (iPSC/2)

Q \#6 How would you rate the UNDERSTANDABILITY of the NODE program(s) of the following applications on a scale of 1 to 5 ?

Assume 1 indicates the poorest level and 5 the highest level of understandability

rings/beard

rings/huson/c .

rings/proicou

meshs/beard. .

meshs/fife

meshs/harding .

meshs/huson

meshs/proicou .

sorts/Beard

sorts/Beard_Koch/cube386

sorts/Beard Koch/mem cube

sorts/Fife_Proicou/cubē̄386

sorts/Fife_Proicou/mem_cube

sorts/Harding_Rottman/cube386

sorts/Harding_Rottman/mem_cube

sorts/Huson

heaps/Beard_Koch/cube386

heaps/Beard Koch/mem cube

heaps/Fife_Proicou/cube $\overline{3} 86$

heaps/Fife-Proicou/mem cube heaps/Harding_Rottman/cube386

\begin{tabular}{|c|c|c|c|c|c|}
\hline$(\mathrm{IPSC} / 1)$ & $1-$ & -- & --- & -- & --5 \\
\hline (iPSC/1) & 1--- & $-\cdots$ & --- & -- & ---5 \\
\hline$(\mathrm{iPSC} / 1)$ & 1--- & --- & -- & - & ---5 \\
\hline (iPSC/1) & 1-- & - & -- & -- & ---5 \\
\hline (iPSC/1) & 1--- & $\ldots$ & -.. & --- & --.5 \\
\hline (iPSC/1) & 1--- & --- & -- & -- & --.5 \\
\hline (iPSC/1) & $1--$ & -- & -- & -- & --5 \\
\hline (iPSC/1) & $1-$ & --- & --- & --- & --.5 \\
\hline (iPSC/1) & $1--$ & --- & -- & --- & ---5 \\
\hline (iPSC/2) & $1--$ & -.. & --- & --- & ---5 \\
\hline (iPSC/1) & 1--- & -- & --- & -- & ---5 \\
\hline (iPSC/2) & 1--- & --- & --- & --- & --5 \\
\hline (iPSC/1) & 1--- & -- & --- & -- & ---5 \\
\hline (iPSC/2) & 1--- & --- & --- & -- & ---5 \\
\hline (iPSC/1) & 1-- & -.- & -- & -- & ---5 \\
\hline (iPSC/1) & $1--$ & --- &.-- &.- & --.5 \\
\hline (iPSC/2) & $1--$ & --. & -.- & -- & --5 \\
\hline (iPSC/1) & 1--- & --- & --- & $\cdots$ & --.5 \\
\hline (iPSC/2) & 1--- & -.- & --- & -- & --5 \\
\hline (iPSC/1) & 1--- & -- & --- & $\ldots$ & --5 \\
\hline (iPSC/2) & $1--$ & $\cdots$ & -- & -- & --5 \\
\hline
\end{tabular}




\begin{tabular}{|c|c|c|c|c|c|c|}
\hline heaps/Harding_Rottman/mem cube & (iPSC/1) & 1--- & --- & -- & --- & ---5 \\
\hline heaps/Huson & (iPSC/1) & $1--$ & --- & -- & --- & ---5 \\
\hline projects/NeuralNets/conway & (iPSC/1) & $1--$ & --- & --- & -- & --.5 \\
\hline projects/NeuralNets/simmers & (iPSC/1) & 1--- & --- & --- & --- & ---5 \\
\hline projects/TSP/rottman & (iPSC/1) & $1--$ & -- & --- & --- & ---5 \\
\hline projects/TSP/sawyer & (iPSC/1) & $1--$ & -- & --- & --- & ---5 \\
\hline projects/beard/src/Thesis/parallel & (IPSC/2) & $1--$ & -- & --- & --- & ---5 \\
\hline projects/beard/src/Thesis/serial & (iPSC/2) & $1--$ & -- & -- & -- & --5 \\
\hline projects/beard/src/Version1 & (iPSC/2) & $1--$ & --- & --- & --- &.--5 \\
\hline projects/fife/src & (iPSC/1) & $1--$ & --- & --- & --- & ---5 \\
\hline projects/harding & (iPSC/1) & $1--$ & $-\cdots$ & --- & --- & ---5 \\
\hline projects/huson/src/new_stuff & $(\mathrm{IPSC} / 1)$ & $1--$ & --- & --- & --- & --.5 \\
\hline projects/koch/src & (iPSC/1) & 1 1-- & --- & --- & --- & --.5 \\
\hline projects/proicou/dinephil1 & (iPSC/1) & $1--$ & -- & --- & --- & --.5 \\
\hline projects/proicou/dinephil2 & (iPSC/1) & $1--$ & --- & --- & --- & ---5 \\
\hline tex/compendium/projects/SCPArchive & (iPSC/2) & 1--- & --- & --- & --- & ---5 \\
\hline
\end{tabular}

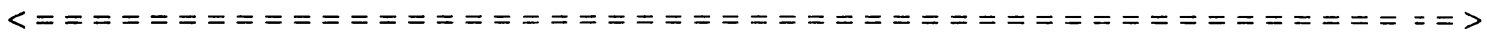

Q \#7. How would you rate the documentation of the HOST program(s) of the following applications on a scale of 1 to 5 ?

Assume 1 indicates the poorest level and 5 the best and most informative level of documentation.

rings/beard
rings/huson/c
rings/proicou
meshs/beard
meshs/fife
meshs/harding
meshs/huson
meshs/proicou.
sorts/Beard
sorts/Beard_Koch/cube386
sorts/Beard_Koch/mem_cube
sorts/Fife_Proicou/cubē386
sorts/Fife-Proicou/mem_cube
sorts/Harding_Rottman/cube386
sorts/Harding_Rottman/mem_cube
sorts/Huson-.
heaps/Beard_Koch/cube386
heaps/Beard_Koch/mem_cube
heaps/Fife_Proicou/cubē386
heaps/Fife_Proicou/mem_cube
heaps/Harding_Rottman/cube386
heaps/Harding_Rottman/mem_cube
heaps/Huson_-
projects/NeuralNets/conway
projects/NeuralNets/simmers
projects/TSP/rottman .
projects/TSP/sawyer
projects/beard/src/Thesis/parallel
projects/beard/src/Thesis/serial

\begin{tabular}{|c|c|c|c|c|c|}
\hline (iPSC/1) & $1--$ & --- & --- & --- & ---5 \\
\hline (iPSC/1) & 1--- & --- & --- & --. & --.5 \\
\hline (iPSC/1) & 1--- & --- & --. & --- & --5 \\
\hline (iPSC/1) & $1--$ & --- & --- & --- & --5 \\
\hline$(\mathrm{PSC} / 1)$ & 1--- & --- & --- & --- & --.5 \\
\hline (iPSC/1) & $1--$ & --- & --- & --- & --5 \\
\hline (iPSC/1) & 1--- & --- & --- & --- & ---5 \\
\hline (iPSC/1) & $1--$ & --- & --- & --- & --5 \\
\hline (iPSC/1) & $1--$ & --- & --. & --- & --5 \\
\hline (iPSC/2) & $1 \ldots$ & -.- & --- & --- & --.5 \\
\hline (IPSC/1) & $1-$. & --- & --- & --- & ---5 \\
\hline$(\mathrm{iPSC} / 2)$ & $1-$ & --. & -..- & -.- & --.5 \\
\hline (iPSC/1) & 1--- & --- & --- & --- & --.5 \\
\hline (iPSC/2) & $1--$ & $\ldots$ & -- & --- & --5 \\
\hline (iPSC/1) & $1--$ & --- & --- & --. & --5 \\
\hline (iPSC/1) & $1--$ & --- & --- & --- & --5 \\
\hline$(\mathrm{iPSC} / 2)$ & 1--- & --- & --- & --. &.- .5 \\
\hline$(\mathrm{IPSC} / 1)$ & 1--- & $\cdots$ & --- & -- & $\cdots .5$ \\
\hline (iPSC/2) & $1--$ & --- & --- & --- & ---5 \\
\hline (iPSC/1) & 1--- & --- &.-- & --- & ---5 \\
\hline (iPSC/2) & 1--- & --- & --- & --- & ---5 \\
\hline (iPSC/1) & $1--$ & --- & --- & --- & --.5 \\
\hline$(\mathrm{IPSC} / 1)$ & $1--$ & --- & --- & --- & --.5 \\
\hline (iPSC/1) & 1-- & --- & -- & --- &.- .5 \\
\hline (iPSC/1) & 1--- & --- & -- & --- & ---5 \\
\hline (iPSC/1) & 1--- & --- & --- & --- & --5 \\
\hline (iPSC/1) & $1--$ & --- & --- & --- & $\ldots .5$ \\
\hline $\mathrm{C} / 2)$ & $1-$ & --- & --- & --- & --5 \\
\hline (iPSC/2) & $1--$ & --. & --- & --- & --5 \\
\hline
\end{tabular}




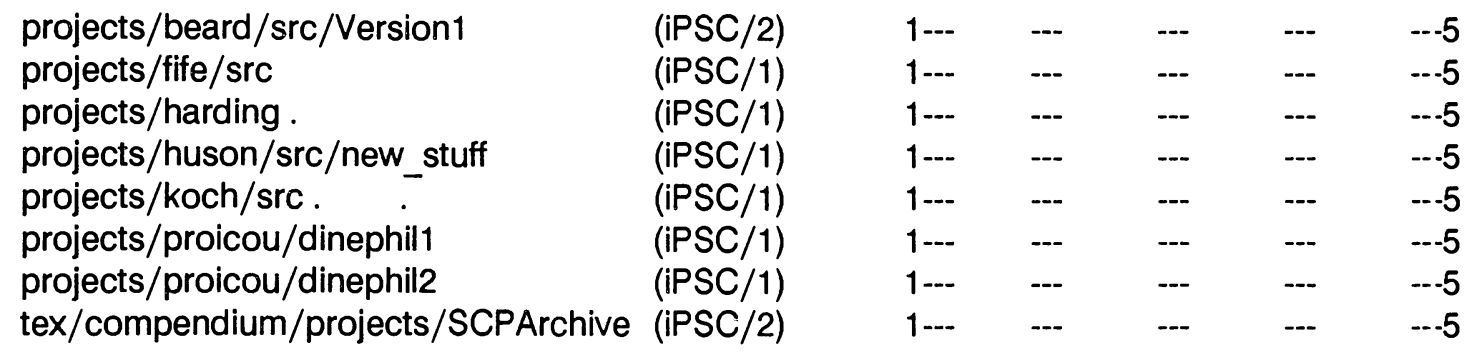

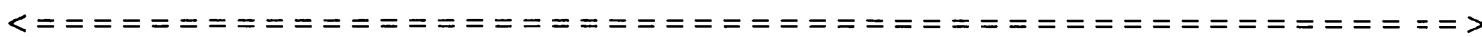

Q \#8: How would you rate the documentation of the NODE program(s) of the following applications on a scale of 1 to 5 ?

Assume 1 indicates the poorest level and 5 the best and most informative level of documentation

rings/beard

rings/huson/c .

rings/proicou

meshs/beard

meshs/fife

meshs/harding

meshs/huson

meshs/proicou .

sorts/Beard

sorts/Beard Koch/cube386.

sorts/Beard Koch/mem cube

sorts/Fife Proicou/cube $\overline{3} 86$

sorts/Fife-Proicou/mem cube

sorts/Harding_Rottman/cube386

sorts/Harding_Rottman/mem_cube

sorts/Huson

heaps/Beard_Koch/cube386

heaps/Beard Koch/mem cube .

heaps/Fife Proicou/cube $\overline{3} 86$

heaps/Fife Proicou/mem cube

heaps/Harding_Rottman/cube386

heaps/Harding_Rottman/mem_cube .

heaps/Huson

projects/NeuralNets/conway

projects/NeuralNets/simmers

projects/TSP/rottman

projects/TSP/sawyer

projects/beard/src/Thesis/parallel

projects/beard/src/Thesis/serial

projects/beard/src/Version1

projects/fife/src

projects/harding

projects/huson/src/new_stuff

projects/koch/src .

projects/proicou/dinephil1

projects/proicou/dinephil2

tex/compendium/projects/SCPArchive

\begin{tabular}{|c|c|c|c|c|c|}
\hline (iPSC/1) & $1--$ & --- & -- & --- &.--5 \\
\hline (iPSC/1) & $1--$ & $\cdots$ & -- & $\cdots$ & --5 \\
\hline (iPSC/1) & $1 \ldots$ & --- & -- & --- & --.5 \\
\hline (IPSC/1) & $1 \ldots$ & $\therefore$ & -- & --- & --.5 \\
\hline (IPSC/1) & 1--- & --- & --- & --- & --.5 \\
\hline (iPSC/1) & 1--- & --- & -- & -- & --.5 \\
\hline (iPSC/1) & 1--- & --- & -- & --- & ---5 \\
\hline$(\mathrm{IPSC} / 1)$ & $1-$. & -- & -- & --- & ---5 \\
\hline (iPSC/1) & 1-- & --- & -.. & -- & ---5 \\
\hline (iPSC/2) & 1-- & --- & -- & --- & --.5 \\
\hline (iPSC/1) & $1--$ & -- & -- & -- & --.5 \\
\hline (iPSC/2) & $1 \ldots$ & -- & -- & -- & --.5 \\
\hline (iPSC/1) & $1--$ & -- & -- & --- & --.5 \\
\hline$(\mathrm{IPSC} / 2)$ & 1--- & --- & -- & --- &.--5 \\
\hline (iPSC/1) & 1--- & -- & -- & --- & ---5 \\
\hline (iPSC/1) & 1--- & --- & --- & --- & --.5 \\
\hline$(\mathrm{iPSC} / 2)$ & $1--$ & --. & -.- & --- & ---5 \\
\hline (iPSC/1) & $1--$ & --- & -- & --- &.--5 \\
\hline (iPSC/2) & $1-$. & -- & -- & -- & --.5 \\
\hline (iPSC/1) & $1-$ & -- & -- & $\ldots$ & --.5 \\
\hline (iPSC/2) & 1--- & -.- & --- & -.- & --.5 \\
\hline (iPSC/1) & 1-- & -- & -- & --- & ---5 \\
\hline (iPSC/1) & 1--- & --- & -- & -- & --.5 \\
\hline (iPSC/1) & 1--- & -- & -- & -- & --.5 \\
\hline (iPSC/1) & $1 \ldots$ & $\ldots$ & -- & --- & --.5 \\
\hline (iPSC/1) & 1-- & -- & -- & -- & ---5 \\
\hline (iPSC/1) & $1--$ & --- & --- & --- & --.5 \\
\hline$($ IPSC/2) & 1--- & --- & -- & --- & ---5 \\
\hline$(\mathrm{IPSC} / 2)$ & 1--- & --- & -.. & --- & --.5 \\
\hline$(\mathrm{iPSC} / 2)$ & 1--- & --- & -- & --- & --5 \\
\hline$($ IPSC/1) & 1-- & --- & -- & --- & --.5 \\
\hline (iPSC/1) & $1--$ &.-- & -- & --- & ---5 \\
\hline (iPSC/1) & $1-$. & $\ldots$ & -- & --- & --.5 \\
\hline (iPSC/1) & 1--- & --- & -- & -- & --5 \\
\hline (iPSC/1) & 1-- & -- & -- & $\cdots$ & --5 \\
\hline (iPSC/1) & 1-- & --- & -- & --- & ---5 \\
\hline (iPSC/2) & $1--$ & -- & -- & -- & --5 \\
\hline
\end{tabular}




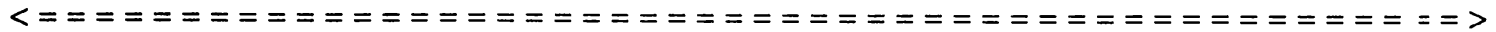

Q \#9: How would you rate the overall perceived or conceptual COMPLEXITY (different frorn computational complexity) of the following applications on a scale of 1 to 5 ?

Assume 1 indicates a lowest level and 5 the highest level of complexity

\begin{tabular}{|c|c|c|c|c|c|c|}
\hline rings/beard & (iPSC/1) & $1--$ & -- & --- & -- & $\ldots-.5$ \\
\hline rings/huson/c & (iPSC/1) & $1--$ & -- & -- & -- & --.5 \\
\hline rings/proicou & (iPSC/1) & $1--$ & -- & --- & --- & ---5 \\
\hline meshs/beard & (iPSC/1) & $1--$ & --- & -- & --- & --5 \\
\hline meshs/fife & (iPSC/1) & $1--$ & --- & --- & --- & ---5 \\
\hline meshs/harding . & (iPSC/1) & 1--- & -- & --- & $-\cdots$ & ---5 \\
\hline meshs/huson & (iPSC/1) & 1-- & --- & --- & --- & ---5 \\
\hline meshs/proicou. & (iPSC/1) & $1--$ & --- & -- & -- & ---5 \\
\hline sorts/Beard & (iPSC/1) & 1--- & -. & --- & --- & --.5 \\
\hline sorts/Beard_Koch/cube386 & (iPSC/2) & 1--- & -- & --- & --- & --.5 \\
\hline sorts/Beard_Koch/mem_cube & (iPSC/1) & $1--$ & -- & --. & --- & ---5 \\
\hline orts/Fife Proicou/cube $\overline{3} 86$ & (iPSC/2) & $1--$ & --- & --- & $\ldots$ & --5 \\
\hline sorts/Fife Proicou/mem cube & (iPSC/1) & $1 \ldots$ & ... & --- & ... & $\ldots .5$ \\
\hline orts/Harding Rottman/cube386 & (iPSC/2) & $1--$ & --- & --- & -- & --5 \\
\hline orts/Harding_Rottman/mem_cube & (iPSC/1) & $1--$ & -- & --- & -- & --5 \\
\hline orts/Huson & (iPSC/1) & $1--$ & -- & --- & --- & ---5 \\
\hline eaps/Beard Koch/cube386 & (iPSC/2) & $1--$ & --- & --- & --- & ---5 \\
\hline eaps/Beard Koch/mem cube & (iPSC/1) & $1--$ & --- & --- & --- & --5 \\
\hline heaps/Fife_Proicou/cube 386 & (iPSC/2) & $1-$ & --- & $\cdots$ & $\cdots$ & --.5 \\
\hline heaps/Fife Proicou/mem cube & (iPSC/1) & 1--- & -- & --- & -- & ---5 \\
\hline heaps/Hard̄ing_Rottman/cube386 & (iPSC/2) & $1--$ & -- & --- & -- &.--5 \\
\hline heaps/Harding_Rottman/mem_cube & (iPSC/1) & $1--$ & --- & --- & --- & --.5 \\
\hline heaps/Huson & (iPSC/1) & $1--$ & --- & --- & -- & --.5 \\
\hline orojects/NeuralNets/conway & (iPSC/1) & $1 \ldots$ & -.- & -.- & -.. & --5 \\
\hline projects/NeuralNets/sımmers & (iPSC/1) & $1 \ldots$ & --- & ... & --. & --5 \\
\hline projects/TSP/rottman & (iPSC/1) & 1--- & --- & --- & --- & ---5 \\
\hline projects/TSP/sawyer & (iPSC/1) & $1--$ &.-- & --- & -- & ---5 \\
\hline projects/beard/src/Thesis/parallel & (IPSC/2) & $1--$ &.-- & $\ldots$ & -- & ---5 \\
\hline projects/beard/src/Thesis/serial & (iPSC/2) & $1--$ & -- & -- & -- & --5 \\
\hline projects/beard/src/Version1 & (iPSC/2) & $1-$ & -- & -- & -- & --5 \\
\hline projects/fife/src & (iPSC/1) & 1--- & --- & --- & -- & ---5 \\
\hline projects/harding. & (iPSC/1) & 1--- & --- & --- & --- & ---5 \\
\hline projects/huson/src/new stuff & (iPSC/1) & 1--- & --- & --- & --- & ---5 \\
\hline projects/koch/src. & (iPSC/1) & $1--$ & -.- & -.. & -.. & --.5 \\
\hline rojects/proicou/dinephil1 & (iPSC/1) & $1--$ & --- & --- & --- & $\ldots$ \\
\hline rojects/proicou/dinephil2 & (iPSC/1) & $1--$ & -- & $-\cdots$ & --- &.- \\
\hline $\mathrm{x} /$ compendium/projects/SC & $\mathrm{C} / 2)$ & $1--$ & -- & --- & --- & \\
\hline
\end{tabular}


$Q$ \#10. If the following applications had been developed as sequential programs, do you think they would have taken less/more/same amount of time and effort?

\begin{tabular}{|c|c|c|c|c|}
\hline & & Less & More & Same \\
\hline rings/beard & (iPSC/1) & --- & --- & -- \\
\hline rings/huson/c . & (iPSC/1) & --- & -- & -- \\
\hline rings/proicou & (iPSC/1) & --- & --- & -- \\
\hline meshs/beard & (iPSC/1) & -- & -- & -- \\
\hline meshs/fife & (iPSC/1) & -.- & -- & --- \\
\hline meshs/harding & (iPSC/1) & -- & -- & --- \\
\hline meshs/huson & (iPSC/1) & -- & --- & -- \\
\hline meshs/proicou & (iPSC/1) & -- & --- & --- \\
\hline sorts/Beard & (iPSC/1) & -- & -- & --- \\
\hline sorts/Beard Koch/cube386 & (iPSC/2) & -.. & -.- & -.- \\
\hline sorts/Beard_Koch/mem_cube & (iPSC/1) & -- & --- & --- \\
\hline sorts/Fife Proicou/cube 386 & (iPSC/2) & $\cdots$ & -- & 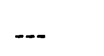 \\
\hline sorts/Fife_Proicou/mem_cube & (IPSC/1) & -- & --- & --- \\
\hline sorts/Harding_Rottman/cube386 & (iPSC/2) & $-\ldots$ & --- & -- \\
\hline sorts/Harding_Rottman/mem_cube & $(\mathrm{IPSC} / 1)$ & -- & -- & --- \\
\hline sorts/Huson & (iPSC/1) & -- & -- & -- \\
\hline heaps/Beard_Koch/cube386 & (iPSC/2) & ... & -- & -- \\
\hline heaps/Beard Koch/mem cube & (iPSC/1) & -- & -- & --- \\
\hline heaps/Fife_Proicou/cube $\overline{3} 86$ & (iPSC/2) & -- & -- & -- \\
\hline heaps/Fife-Proicou/mem cube & (iPSC/1) & -- & --- & --- \\
\hline heaps/Harding Rottman/cube386 & (iPSC/2) & -- & --- & -.. \\
\hline heaps/Harding_Rottman/mem cube & (iPSC/1) & $\cdots$ & -- & --- \\
\hline heaps/Huson & (iPSC/1) & -- & -- & -- \\
\hline projects/NeuralNets/conway & (iPSC/1) & --- & --- & --- \\
\hline projects/NeuralNets/simmers & (iPSC/1) & -- & -- & --- \\
\hline projects/TSP/rottman & (iPSC/1) & --- & --- & -- \\
\hline projects/TSP/sawyer & (iPSC/1) & --- & --- & -- \\
\hline projects/beard/src/Thesis/parallel & (iPSC/2) & --- & --- & --- \\
\hline projects/beard/src/Thesis/serial' & (iPSC/2) & -- & -- & --- \\
\hline projects/beard/src/Version1 & (iPSC/2) & -- & -- & - \\
\hline projects/fife/src & $($ IPSC $/ 1)$ & -- & -- & -- \\
\hline projects/harding & (iPSC/1) & --- & $-\cdots$ & --- \\
\hline projects/huson/src/new_stuff & (iPSC/1) & -- & --- & -- \\
\hline projects/koch/src . & (iPSC/1) & $-\cdots$ & --- & -- \\
\hline projects/proicou/dinephil1 & (iPSC/1) & -.. &.-- & -- \\
\hline projects/proicou/dinephil2 & (iPSC/1) & --- & --- & --- \\
\hline tex/compendium/projects/SCPArchive & (iPSC/2) & -- & -- & -- \\
\hline
\end{tabular}

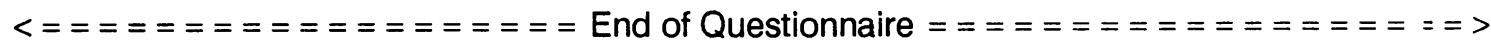


APPENDIX B.2: APPLICATION NAMES AND ACCUMULATED TOTAL NUMBER OF EXPERTS' REPLIES TO THE QUESTIONS IN THE QUESTIONNAIRE.

\begin{tabular}{|c|c|c|c|c|c|c|c|}
\hline Apl\# & APLNAME & Q5 & Q6 & Q7 & Q8 & Q9 & Q10 \\
\hline 1 & rıngs/beard & 14 & 15 & 16 & 16 & 5 & 8 \\
\hline 2 & meshs/beard & 14 & 15 & 16 & 16 & 5 & 8 \\
\hline 3 & sorts/Beard & 14 & 14 & 15 & 15 & 10 & 4 \\
\hline 4 & sorts/Beard_Koch/cube386 & 14 & 14 & 15 & 15 & 10 & 4 \\
\hline 5 & sorts/Beard_Koch/mem_cube & 14 & 14 & 15 & 15 & 10 & 4 \\
\hline 6 & sorts/Fife_Proicou/cube 386 & 14 & 14 & 15 & 15 & 10 & 4 \\
\hline 7 & sorts/Fife_Proicou/mem_cube & 14 & 14 & 15 & 15 & 10 & 4 \\
\hline 8 & heaps/Beard_Koch/cube386 & 14 & 14 & 15 & 15 & 10 & 4 \\
\hline 9 & heaps/Beard_Koch/mem_cube & 14 & 14 & 15 & 15 & 10 & 4 \\
\hline 10 & heaps/Fife_Proicou/cube 386 & 14 & 14 & 15 & 15 & 10 & 4 \\
\hline 11 & heaps/Fife_Proicou/mem_cube & 14 & 14 & 15 & 15 & 10 & 4 \\
\hline 12 & projects/NeuralNets/conway & 10 & 10 & 12 & 12 & 15 & 3 \\
\hline 13 & projects/NeuralNets/sımmers & 10 & 10 & 12 & 12 & 15 & 3 \\
\hline 14 & projects/TSP/rottman & 11 & 12 & 14 & 13 & 13 & 4 \\
\hline 15 & projects/TSP/sawyer & 13 & 14 & 15 & 14 & 13 & 4 \\
\hline 16 & projects/hardıng & 12 & 11 & 13 & 12 & 14 & 3 \\
\hline 17 & projects/huson/src/new_stuff & 12 & 11 & 13 & 12 & 16 & 3 \\
\hline 18 & projects/koch/src & 12 & 11 & 14 & 13 & 10 & 4 \\
\hline
\end{tabular}

"Q5" to "Q10" represents the Question 5 through Question 10 in the Questionnaire (Appendıx B 1) 
APPENDIX C

PC-METRIC REPORTS AND THE LISTING OF RESERVED AND NON-EXECUTABLE WORDS 


\section{APPENDIX C.1: SAMPLE PC-METRIC REPORT BY PROCEDURE}

$10 / 22 / 1990$

Page: 1

PC-METRIC (C) Version 2.4

Complexity Report by Procedure for: C: \SAMPLE.C

\begin{tabular}{lrrrrrrrrr} 
Procedure & $\mathrm{n} 1$ & $\mathrm{n} 2$ & $\mathrm{~N} 1$ & $\mathrm{~N} 2$ & $\mathrm{~N}$ & $\mathrm{~N}^{\wedge}$ & $\mathrm{P} / \mathrm{R}$ & $\mathrm{V}$ & $\mathrm{E}$ \\
\hline main & 30 & 19 & 106 & 44 & 150 & 228 & 1.5 & 842 & 29256 \\
get_tok & 26 & 32 & 122 & 66 & 188 & 282 & 1.5 & 1101 & 29529 \\
token_type & 9 & 13 & 76 & 33 & 109 & 77 & 0.7 & 486 & 5553 \\
print_stable & 11 & 8 & 26 & 15 & 41 & 62 & 1.5 & 174 & 1796 \\
print_ctable & 13 & 8 & 27 & 16 & 43 & 72 & 1.7 & 189 & 2455
\end{tabular}

$\begin{array}{rrrrr}\text { VG1 } & \text { VG2 } & \text { LOC } & <;> & \text { SP } \\ --- & --- & --- & ---- & -- \\ 6 & 6 & 59 & 19 & 8 \\ 15 & 15 & 76 & 26 & 7 \\ 9 & 9 & 22 & 9 & 3 \\ 3 & 3 & 10 & 6 & 1 \\ 3 & 3 & 13 & 7 & 1\end{array}$

Figure C.2 


\section{APPENDIX C.2: SAMPLE PC-METRIC REPORT BY COMPLEXITY}

$10 / 22 / 1990$

PC-METRIC (C) Version 2.4

Summary Complexity Report for: C: \SAMPLE.RPT

Unique Operators (n1): $\quad 39$

Unique operands (n2): $\quad 64$

Total Operators (N1): $\quad 357$

Total Operands (N2): 174

Software Science Length (N):

Purity Ratio (P/R):

Software Science Volume (V):

3551

Software Science Effort (E):

188234

Estimated Errors using Software Science $\left(B^{\wedge}\right)$ :

Estimated Time to Develop, in hours $\left(\mathrm{T}^{\wedge}\right)$ :

Cyclomatic Complexity (VG1):

Extended Cyclomatic Complexity (VG2): $\quad 32$

Average Cyclomatic Complexity:

Average Extended Cyclomatic Complexity:

Lines of code (LOC):

Number of Procedures/Functions:

Number of Executable Semi-colons $(\langle;\rangle)$ :

Figure C.3 
APPENDIX C.3: iPSC/2-C RESERVED AND NON-EXECUTABLE WORDS

\section{RESERVED WORDS}

\begin{tabular}{|c|c|c|c|c|c|}
\hline$!$ & $!=$ & $"$ & $\%$ & $\%=$ & $\&$ \\
\hline$\& \&$ & $\&=$ & $\& p$ & , & ( & (c \\
\hline$(p$ & ) & $*$ & $*=$ & ${ }^{*} \mathrm{p}$ & + \\
\hline$+t$ & $t=$ & , & - & -- & $-=$ \\
\hline$->$ & . & / & $/=$ & $:$ & ; \\
\hline$<$ & $<<$ & $<<=$ & $<=$ & $=$ & $==$ \\
\hline$>$ & $>=$ & $>>$ & $>>=$ & $?$ & {[} \\
\hline ] & $\hat{\imath}$ & $\hat{\imath}=$ & break & case & continue \\
\hline default & do & else & entry & for & goto \\
\hline if & return & sizeof & switch & while & \{ \\
\hline 1 & $1=$ & 11 & \} & $\sim$ & \\
\hline
\end{tabular}

NON-EXECUTABLE WORDS

$\begin{array}{llllll}\text { auto } & \text { char } & \text { const } & \text { double } & \text { enum } & \text { extern } \\ \text { FILE } & \text { float } & \text { int } & \text { long } & \text { register } & \text { short } \\ \text { signedstatic } & \text { struct } & \text { typedef } & \text { union } & \text { unsigned } & \text { void } \\ \text { volatile } & & & & & \end{array}$


APPENDIX D

PARALLEL PROGRAM TO COLLECT

SIZE MEASUREMENTS 

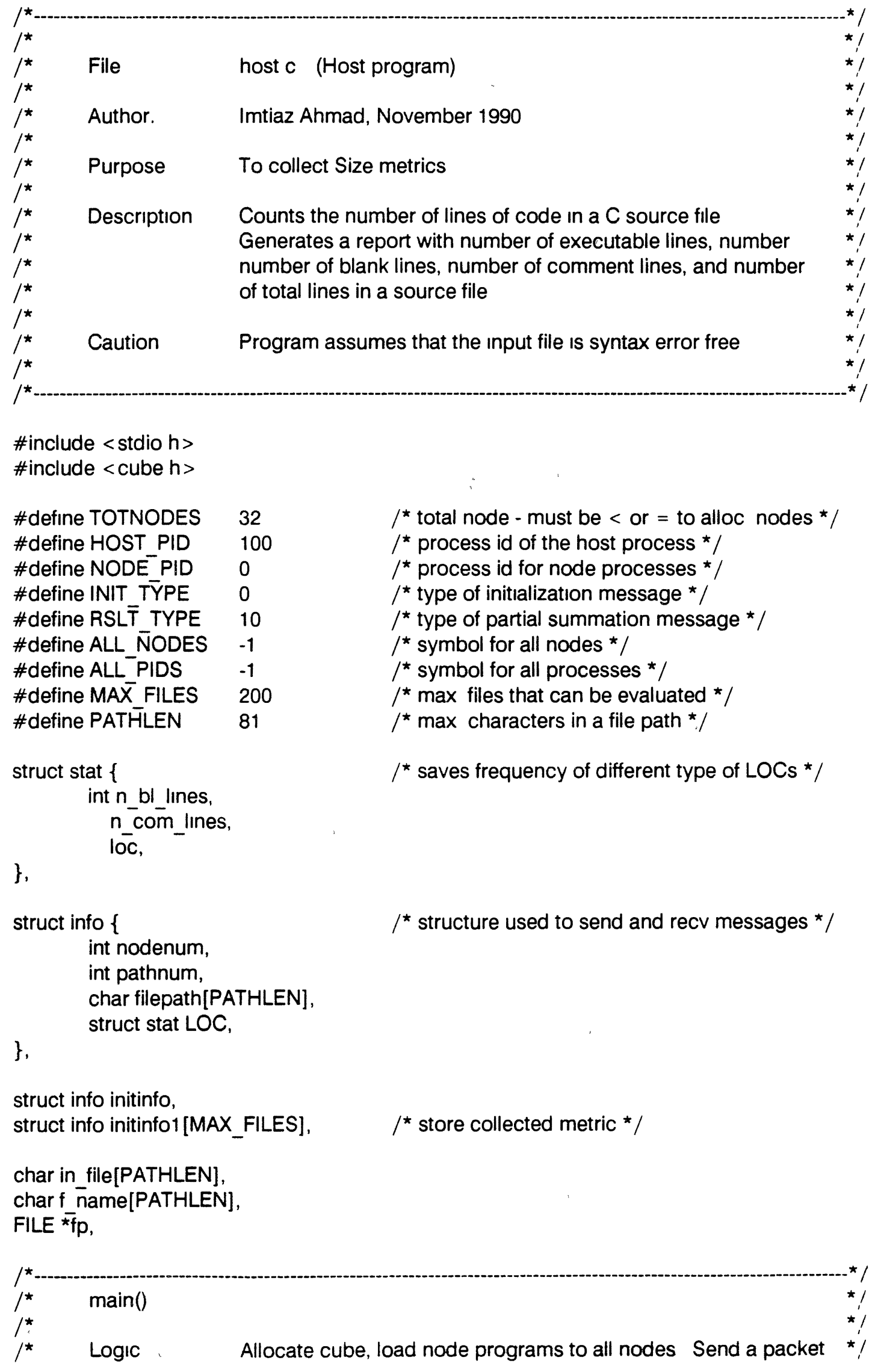


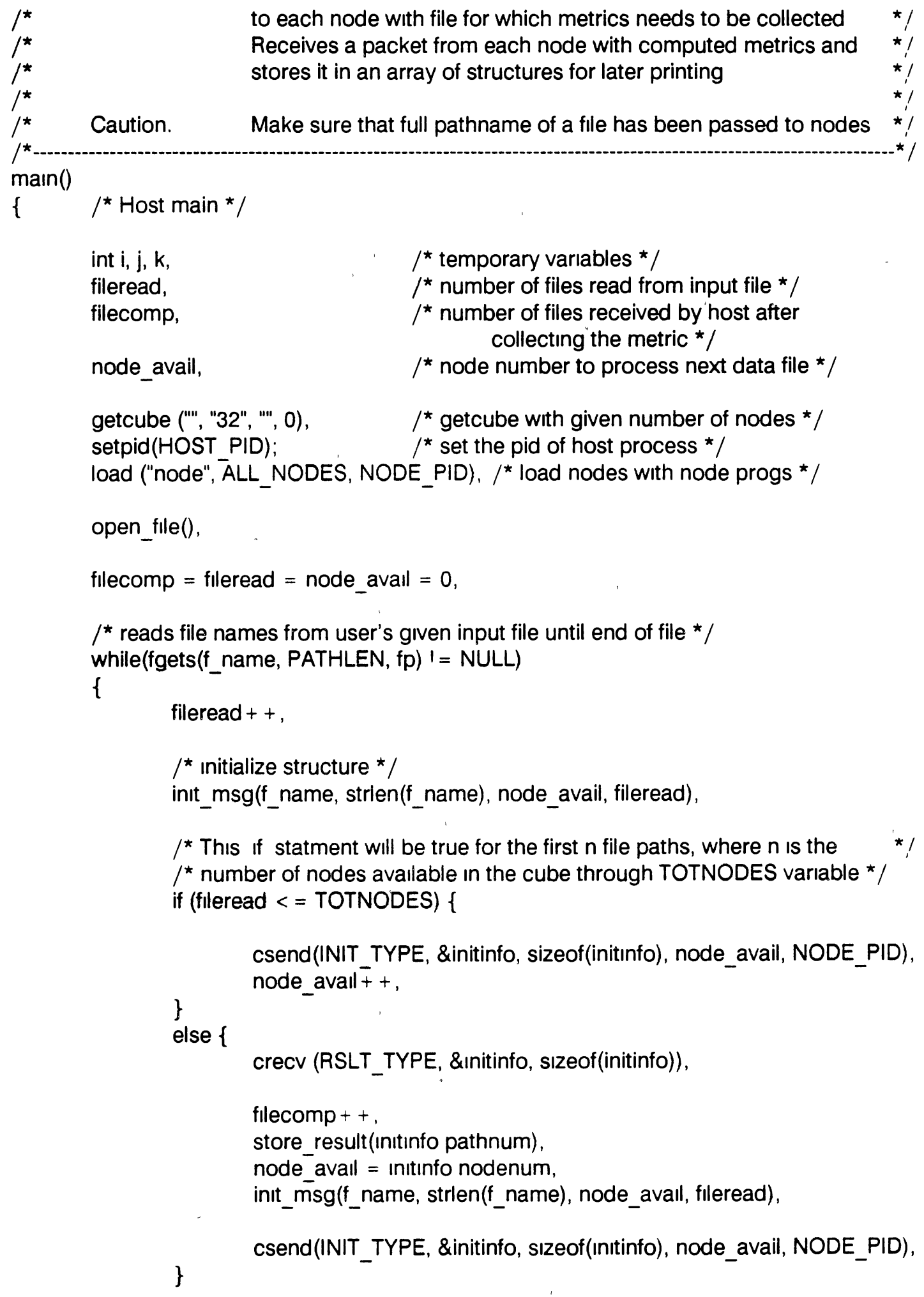

\section{\} / "while fgets ${ }^{*} /$}

$/^{\star}$ This if statment checks whether all activated files are received by the host or node * / if (fileread $\mathrm{I}=$ filecomp) \{ for $(j=$ fllecomp, $j<$ fileread, $j++)\{$ 
crecv (RSLT_TYPE, \&initinfo, sizeof(ınıtinfo)),

$/{ }^{*}$ store result in an array of stuctures * /

\}

store_result(initinfo pathnum),

\}

$/$ * print results on screen */

print_result(fileread),

fclose(fp), $\quad /$ * close input file */

killcube(ALL_NODES, ALL_PIDS), /* kill cube * /

relcube (), - $\quad / *$ release cube *

printf("Normal termination of the program $\backslash n "$ "),

\} $/$ * End host main */

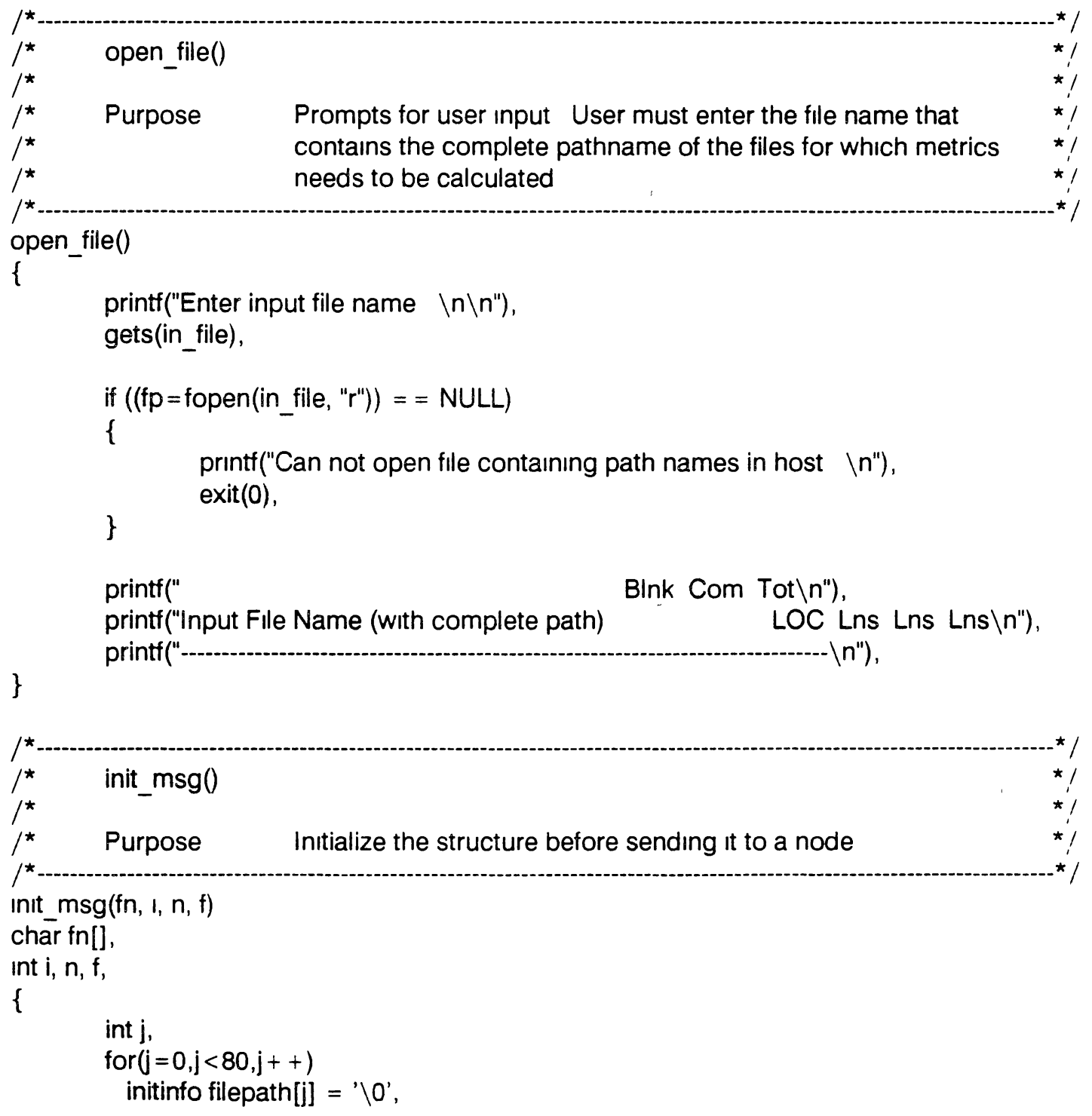









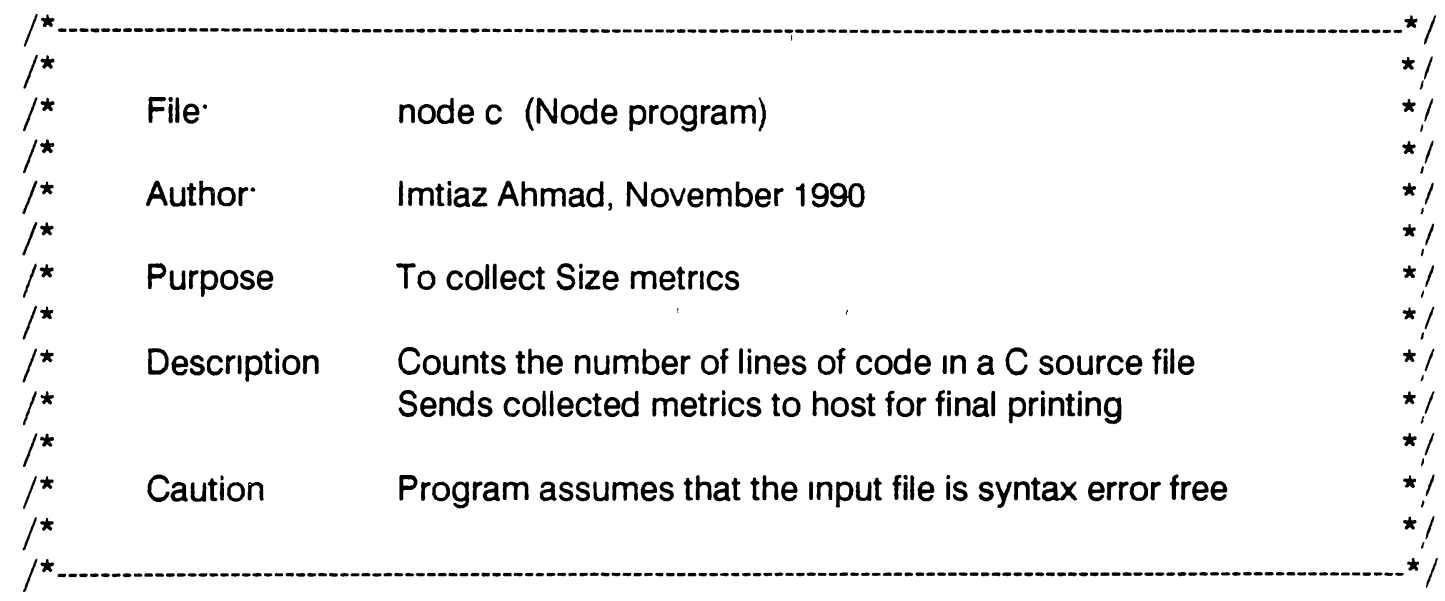

\#include $<$ stdio $\mathrm{h}>$
\#include $<$ cube $\mathrm{h}>$

\#define TRUE 1

\#define FALSE 0

\#define MAXLINE 150

\#define BLANK , ,

\#define SLASH

\#define STAR

\#define TOTNODES 32

\#define HOST PID 100

\#define NODE

\#define INIT TYYPE 0

\#define RSLT TYPE 10

\#define ALL NNODES -1

\#define ALL'PIDS -1

\#define MAX̄ FILES 200

\#define PATHLEN 81

struct stat \{

int $n$ bl lines, n_com_lines,

loc,

\} ,

struct info \{

int nodenum,

int pathnum,

char filepath[PATHLEN],

\} , struct stat LOC,

struct stat temp,

struct info initinfo,

struct info initinfo1[MAX_FILES],

$/^{\star}$ store computed metric */

$/ *$ process id of the host process */

$/ *$ process id for node processes * /

$/{ }^{\star}$ type of initialization message $* /$

$/^{\star}$ symbol for all nodes *

$/{ }^{*}$ symbol for all processes *

$/{ }^{*}$ max files that can be evaluated */

$/{ }^{*}$ max characters in a file path * $/$

$/{ }^{\star}$ saves frequency of LOCs *

char in file[PATHLEN],

charf_name[PATHLEN],

/ assignıng symbolic names to program constants * /

$/ *$ total nodes - must be $<$ or $=$ to alloc nodes *

$/^{*}$ type of partial summation message * $/$

$/{ }^{*}$ structure used to send and recv messages * / 
FILE * ${ }^{\prime} p$,

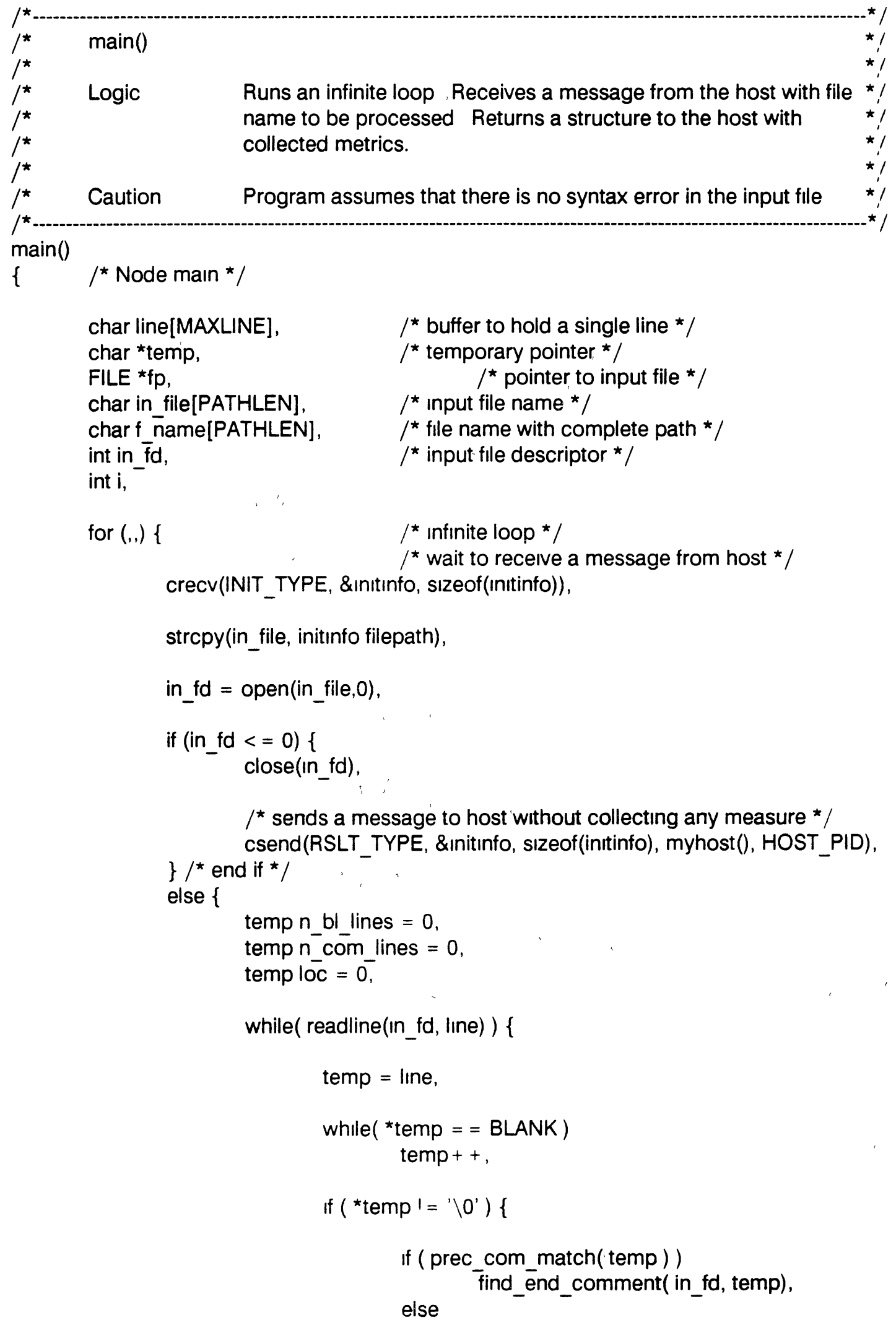




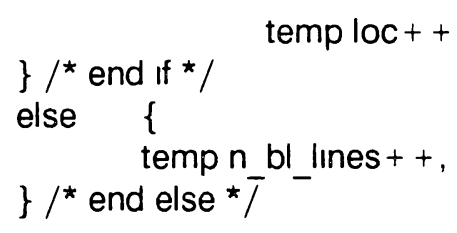

\} / End WHILE GETLINE * /

initinfo nodenum $=$ mynode $($ ),

Initinfo LOC n_bl_lines = temp n_bl_lines,

initinfo LOC n_com_lines = temp n_com_lınes,

initinfo LOC IOC = temp loc,

csend(RSLT_TYPE, \&ınitinfo, sizeof(initinfo), myhost(), HOST_PID),

close(in fd),

\} $/{ }^{\star}$ end else */

\}$/{ }^{*}$ end infinite loop */

\}$/ *$ end Node main */

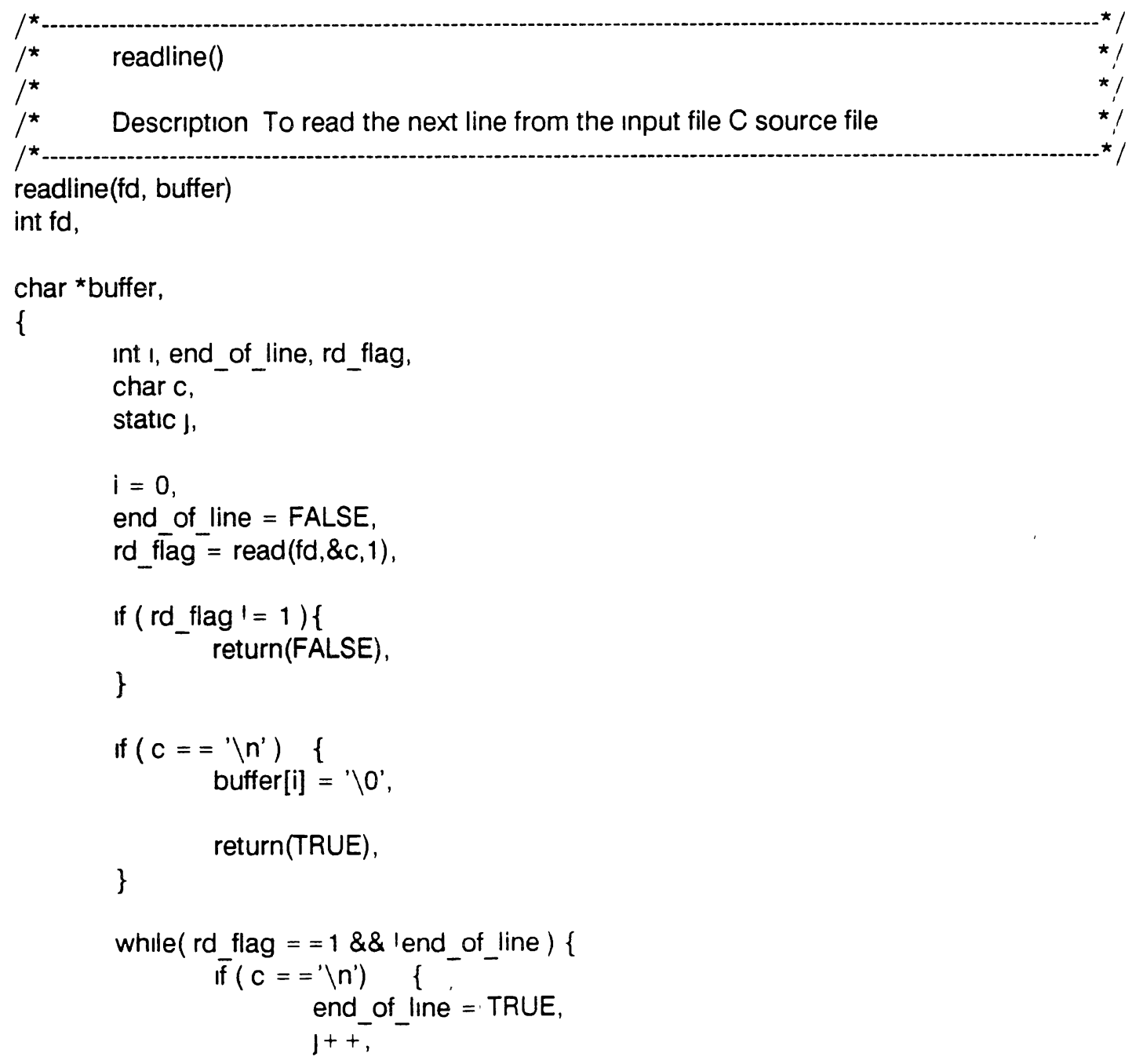




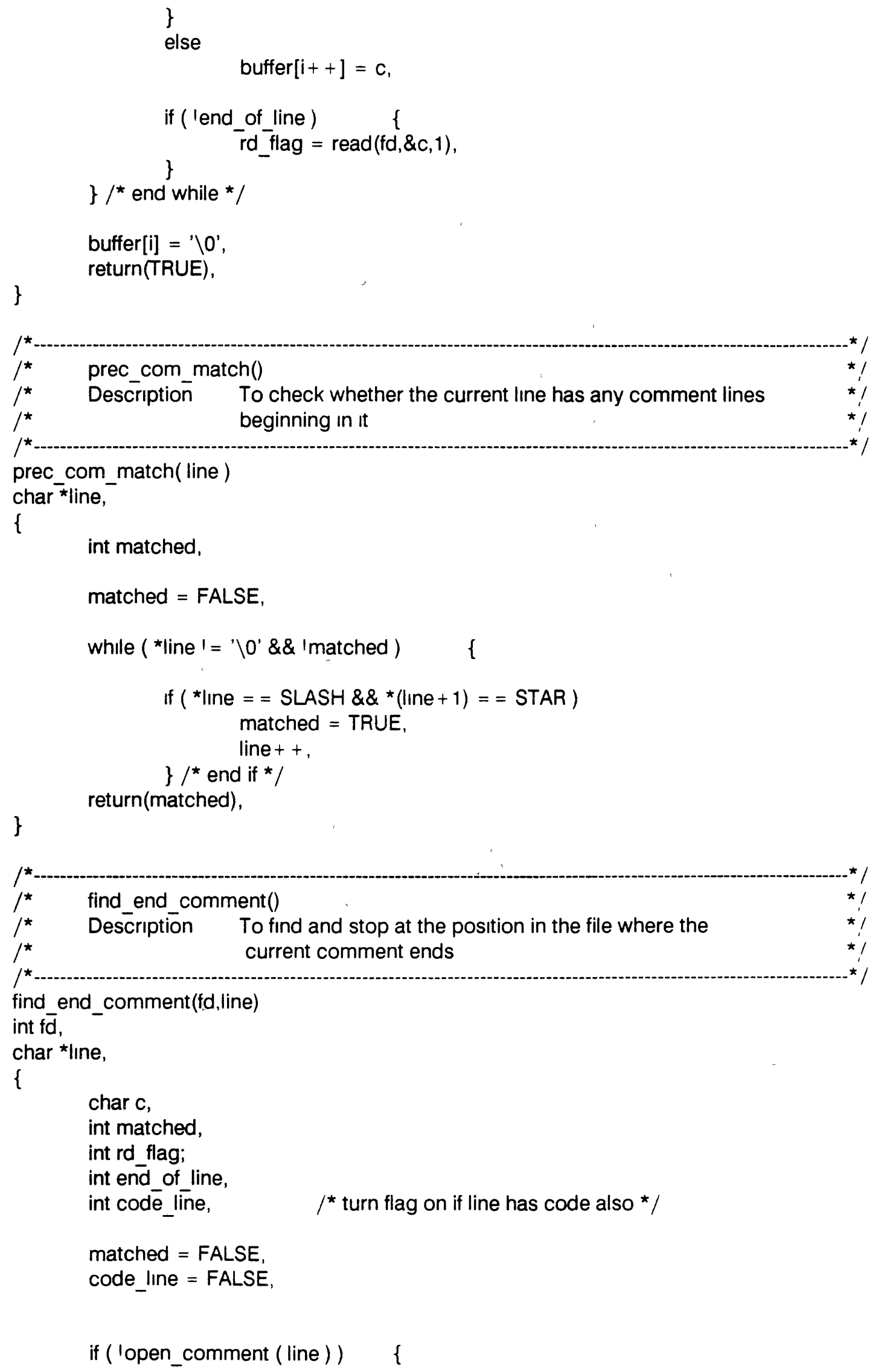




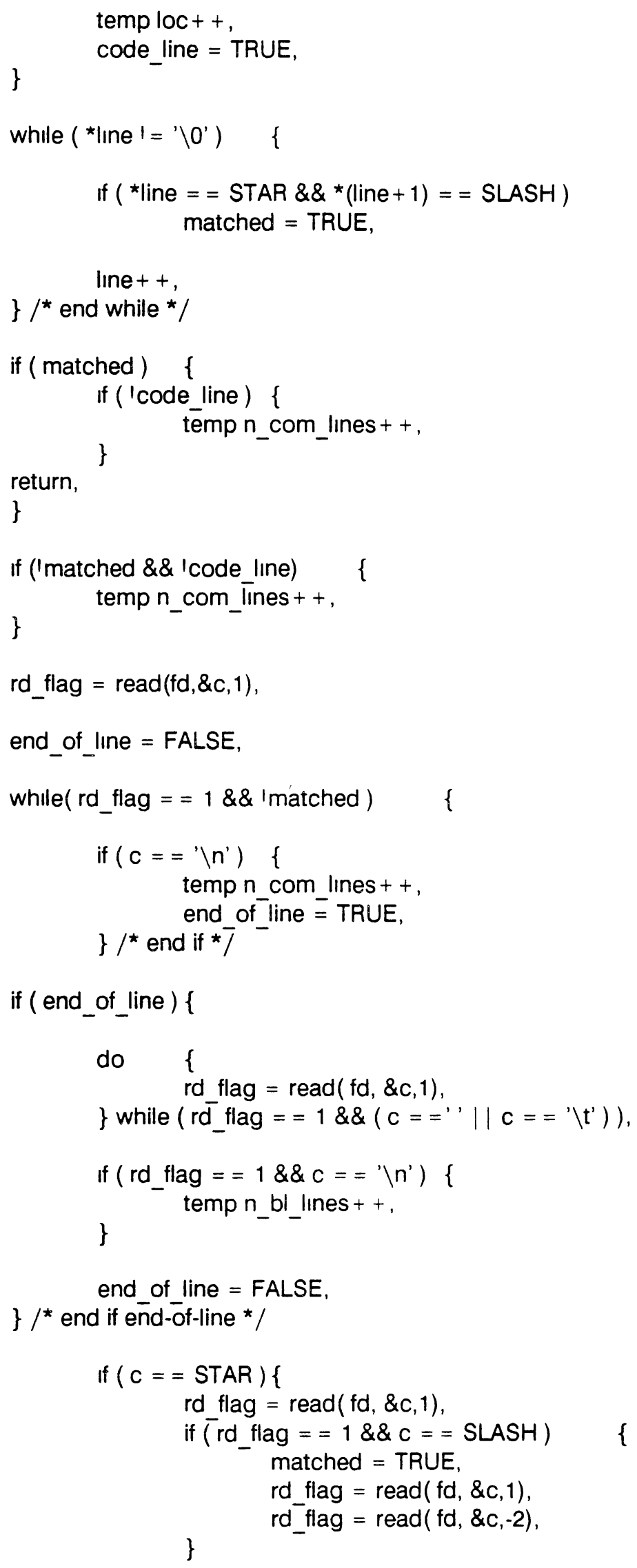




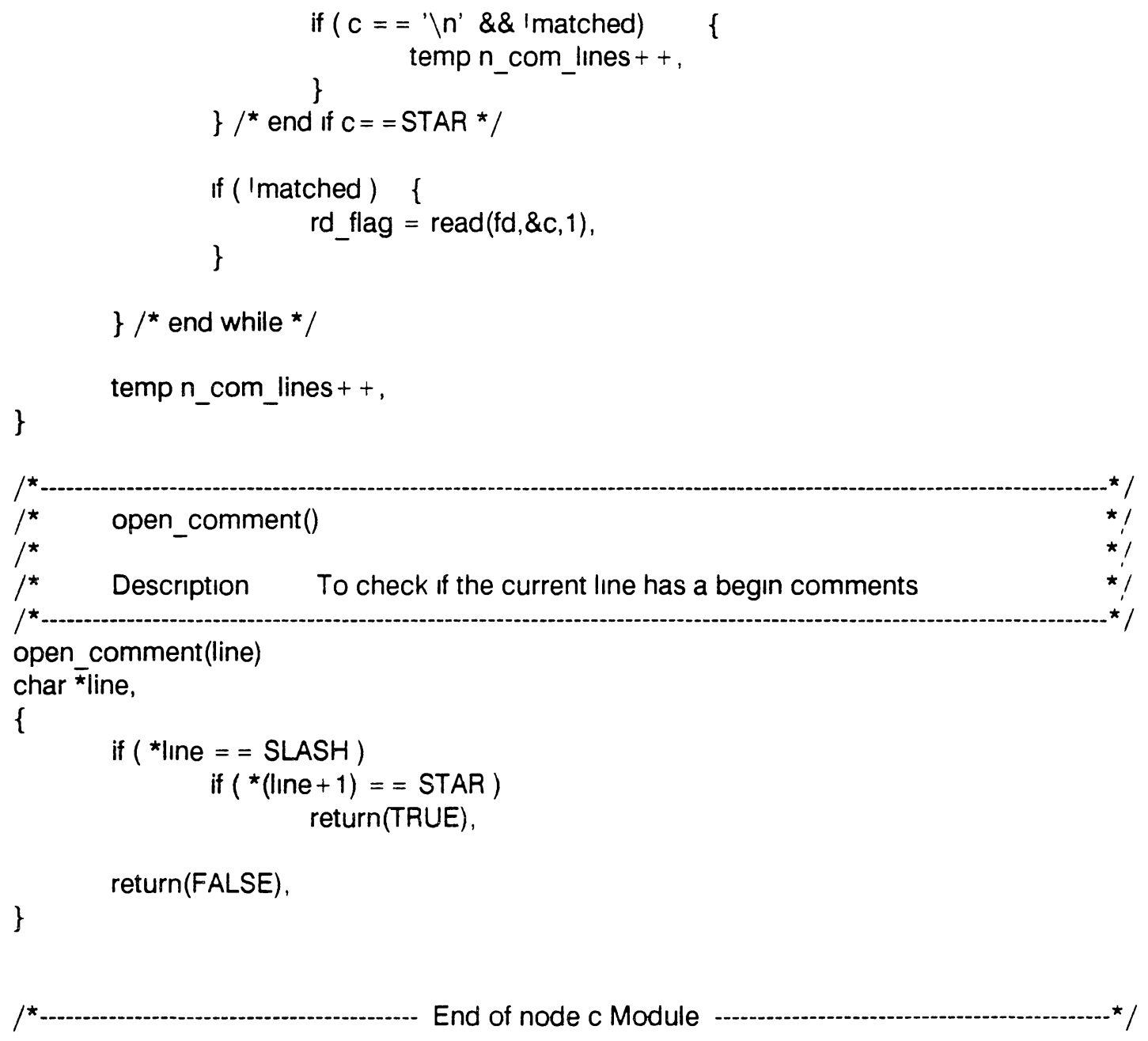


APPENDIX E

PSEUDO CODE, FILE LISTING, AND MAKEFILE 
APPENDIX E.1: PSEUDO CODE FOR THE PARALLEL PROGRAMS DEVELOPED TO COLLECT THE SIZE AND THE COMMUNICATION MEASUREMENTS.

$h^{1} 1: \quad$ (Host) Getcube with $n$ number of nodes $(n=1,2, \ldots 32)$;

h2: (Host) Load node program to each node in the allocated cube;

h3: (Host) Prompt for input file that has data file names with their complete paths;

h4: (Host) Initialıze flags and counters;

h5: $\quad$ (Host) Initialize filesread $=$ filescompleted $=0$;

h6: (Host) While (!EOF) read a file name to be processed;

h7: (Host) filesread ++ ;

h8: (Host) initialize message packet;

h9: (Host) if (filesread $<=$ Totalnodes) \{ send packet (message) to node_available; node available + +;

$\mathrm{n}^{2} 1:$ (Node) $\quad$ for $(; ;)\left\{/{ }^{*}\right.$ infinite loop * receives a packet with filename to be processed;

n2: (Node) Initialize metric counters to zero;

n3: (Node)

While (Valid Token) \{ detect token type and increment the appropriate counter;

\} /* end of While loop started at n3: */

n4: (Node) send a packet back to host with collected metrics; \} / end of infinite loop on node started at $n 1:$ / else \{ receive a message from node that has just completed the metrics from the file it was processing; filescompleted ++ ; store result; update node available; send new file name to node available; \}$/ *$ end of else statement */

h10: (Host) \} /* end of while started at h6: */

1 "h" represents code running on the Host processor.

2 " $n$ " represents code running on the Node processors. 
h11: (Host) if (filesread ! = filescompleted) \{

$$
\begin{aligned}
& \text { for }(j=\text { filescompleted; } j<\text { filesread; } j++)\{ \\
& \text { receive computed metrics from nodes; } \\
& \text { store result; } \\
& \}^{*} \text { * end of for loop * }
\end{aligned}
$$

h12: (Host) end of the Host program; 


\section{APPENDIX E.2: THE COMPLETE PATH OF SOURCE CODE FILES} USED IN THIS STUDY.

\begin{tabular}{|c|}
\hline $\begin{array}{l}\text { tex/programs/heaps/Beard_Koch/cube386/heap.c } \\
\text { tex/programs/heaps/Beard_Koch/cube386/host.c }\end{array}$ \\
\hline $\begin{array}{l}\text { tex/programs/heaps/Beard_Koch/mem_cube/heap.c } \\
\text { tex/programs/heaps/Beard_Koch/mem_cube/host.c }\end{array}$ \\
\hline $\begin{array}{l}\text { tex/programs/heaps/Fife_Proicou/cube386/HeapSort.c } \\
\text { tex/programs/heaps/Fife_Proicou/cube386/NodeHeap.c }\end{array}$ \\
\hline $\begin{array}{l}\text { tex/programs/heaps/Fife_Proicou/mem_cube/HeapSort.c } \\
\text { tex/programs/heaps/Fife_Proicou/mem_cube/NodeHeap.c }\end{array}$ \\
\hline $\begin{array}{l}\text { tex/programs/meshs/beard/h.c } \\
\text { tex/programs/meshs/beard/n.c }\end{array}$ \\
\hline $\begin{array}{l}\text { tex/programs/projects/NeuralNets/conway/host.c } \\
\text { tex/programs/projects/NeuralNets/conway/node.c }\end{array}$ \\
\hline $\begin{array}{l}\text { tex/programs/projects/NeuralNets/simmers/host.c } \\
\text { tex/programs/projects/NeuralNets/simmers/node.c }\end{array}$ \\
\hline $\begin{array}{l}\text { tex/programs/projects/TSP/rottman/control.c } \\
\text { tex/programs/projects/TSP/rottman/host.c } \\
\text { tex/programs/projects/TSP/rottman/worker.c }\end{array}$ \\
\hline $\begin{array}{l}\text { tex/programs/projects/TSP/sawyer/control.c } \\
\text { tex/programs/projects/TSP/sawyer/host.c } \\
\text { tex/programs/projects/TSP/sawyer/node.h } \\
\text { tex/programs/projects/TSP/sawyer/worker.c }\end{array}$ \\
\hline $\begin{array}{l}\text { tex/programs/projects/harding/ben.c } \\
\text { tex/programs/projects/harding/host.c } \\
\text { tex/programs/projects/harding/q.h } \\
\text { tex/programs/projects/harding/queue.c }\end{array}$ \\
\hline $\begin{array}{l}\text { tex/programs/projects/huson/src/new_stuff/host.c } \\
\text { tex/programs/projects/huson/src/new_stuff/parallel.c } \\
\text { tex/programs/projects/huson/src/new_stuff/serial.c }\end{array}$ \\
\hline $\begin{array}{l}\text { tex/programs/projects/koch/src/host.c } \\
\text { tex/programs/projects/koch/src/node.c }\end{array}$ \\
\hline $\begin{array}{l}\text { tex/programs/rings/beard/host.c } \\
\text { tex/programs/rings/beard/node.c }\end{array}$ \\
\hline
\end{tabular}




\begin{tabular}{l} 
tex/programs/sorts/Beard/cmpf.c \\
tex/programs/sorts/Beard/local.h \\
tex/programs/sorts/Beard/msgio.c \\
tex/programs/sorts/Beard/msgtypes.h \\
tex/programs/sorts/Beard/parsorts.c \\
tex/programs/sorts/Beard/scpgbl.h \\
tex/programs/sorts/Beard/srlsorts.c \\
\hline tex/programs/sorts/Beard_Koch/cube386/bmerge.c \\
tex/programs/sorts/Beard_Koch/cube386/host.c \\
tex/programs/sorts/Beard_Koch/cube386/local.h \\
tex/programs/sorts/Beard_Koch/cube386/merge.c \\
tex/programs/sorts/Beard_Koch/cube386/oddeven.c \\
\hline tex/programs/sorts/Beard_Koch/mem_cube/bmerge.c \\
tex/programs/sorts/Beard_Koch/mem_cube/host.c \\
tex/programs/sorts/Beard_Koch/mem_cube/local.h \\
tex/programs/sorts/Beard_Koch/mem_cube/merge.c \\
tex/programs/sorts/Beard_Koch/mem_cube/oddeven.c \\
\hline tex/programs/sorts/Fife_Proicou/cube386/Bitonic.c \\
tex/programs/sorts/Fife_Proicou/cube386/OddEven.c \\
tex/programs/sorts/Fife_Proicou/cube386/Radix.c \\
tex/programs/sorts/Fife_Proicou/cube386/msort.c \\
tex/programs/sorts/Fife_Proicou/cube386/sort.c \\
\hline tex/programs/sorts/Fife_Proicou/mem_cube/Bitonic.c \\
tex/programs/sorts/Fife_Proicou/mem_cube/OddEven.c \\
tex/programs/sorts/Fife_Proicou/mem_cube/Radix.c \\
tex/programs/sorts/Fife_Proicou/mem_cube/msort.c \\
tex/programs/sorts/Fife_Proicou/mem_cube/sort.c \\
\hline
\end{tabular}


APPENDIX E.3: THE MAKE FILE USED TO COMPILE PROGRAMS

DEVELOPED FOR COLLECTING THE SIZE AND THE

COMMUNICATION MEASUREMENTS.

$/ *$

* makefile

$\star$

*

* This file is used to compile and link the host.c and node.c files for the parallel

* programs developed to measure size and communication metrics.

* The command "make all" causes compilation and linking.

*/

all: $\quad$ host node

sx: $\quad$ host nodesx

host: host.o

cc -o host host.o -host

nodesx: $\quad$ node.c

cc node.c -o node -sx -node

node: node.c

cc - o node node.c -node -sx

clean:

rm host node host.o 


\section{APPENDIX F}

PARALLEL PROGRAM TO COLLECT COMMUNICATION MEASUREMENTS 

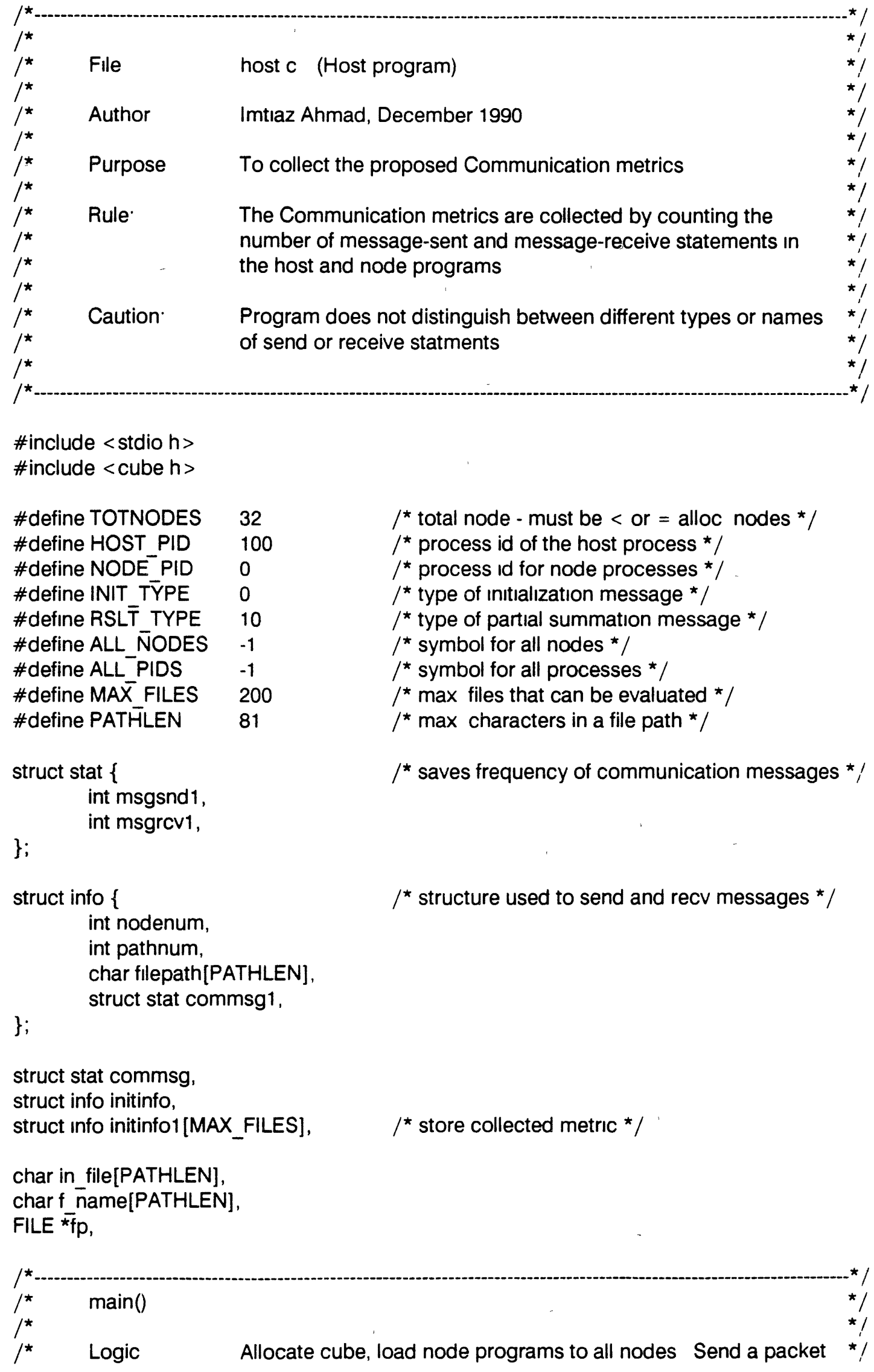


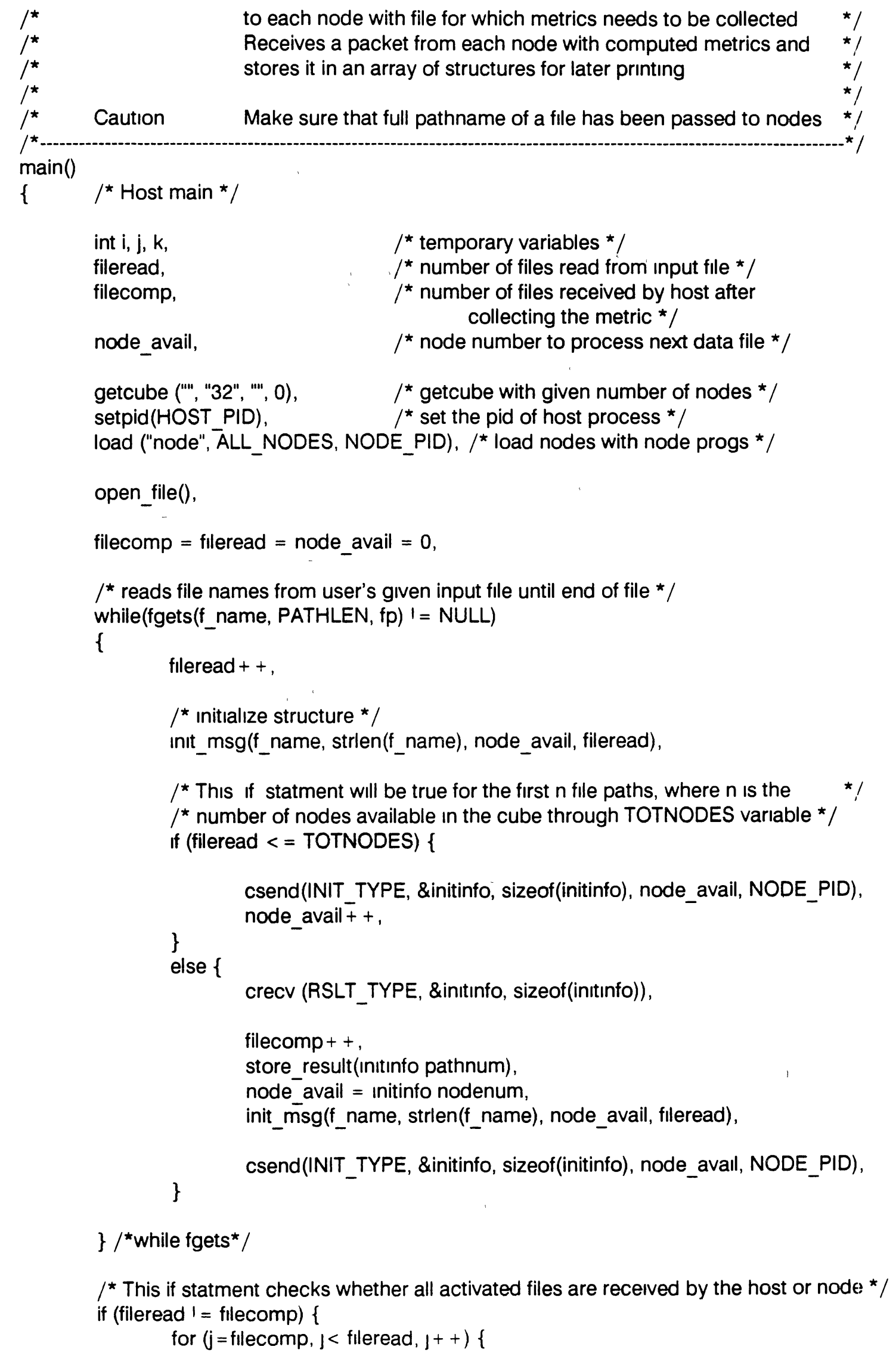




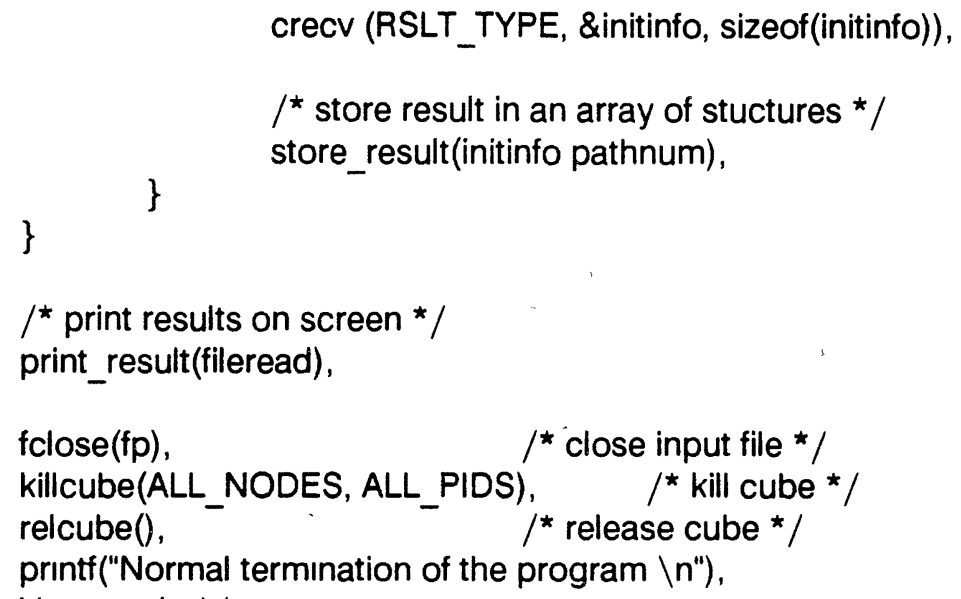

printf("\%4d \%4d \%4d \%4d \%s $\backslash n$ ", initınfo1 [i+1] nodenum, initinfo1 [i+1] pathnum, inıtinfo1 [i+1] commsg1 msgsnd1, initınfo1 [1+1] commsg1 msgrcv1, Inıtinfo1 [1+1] filepath), \}

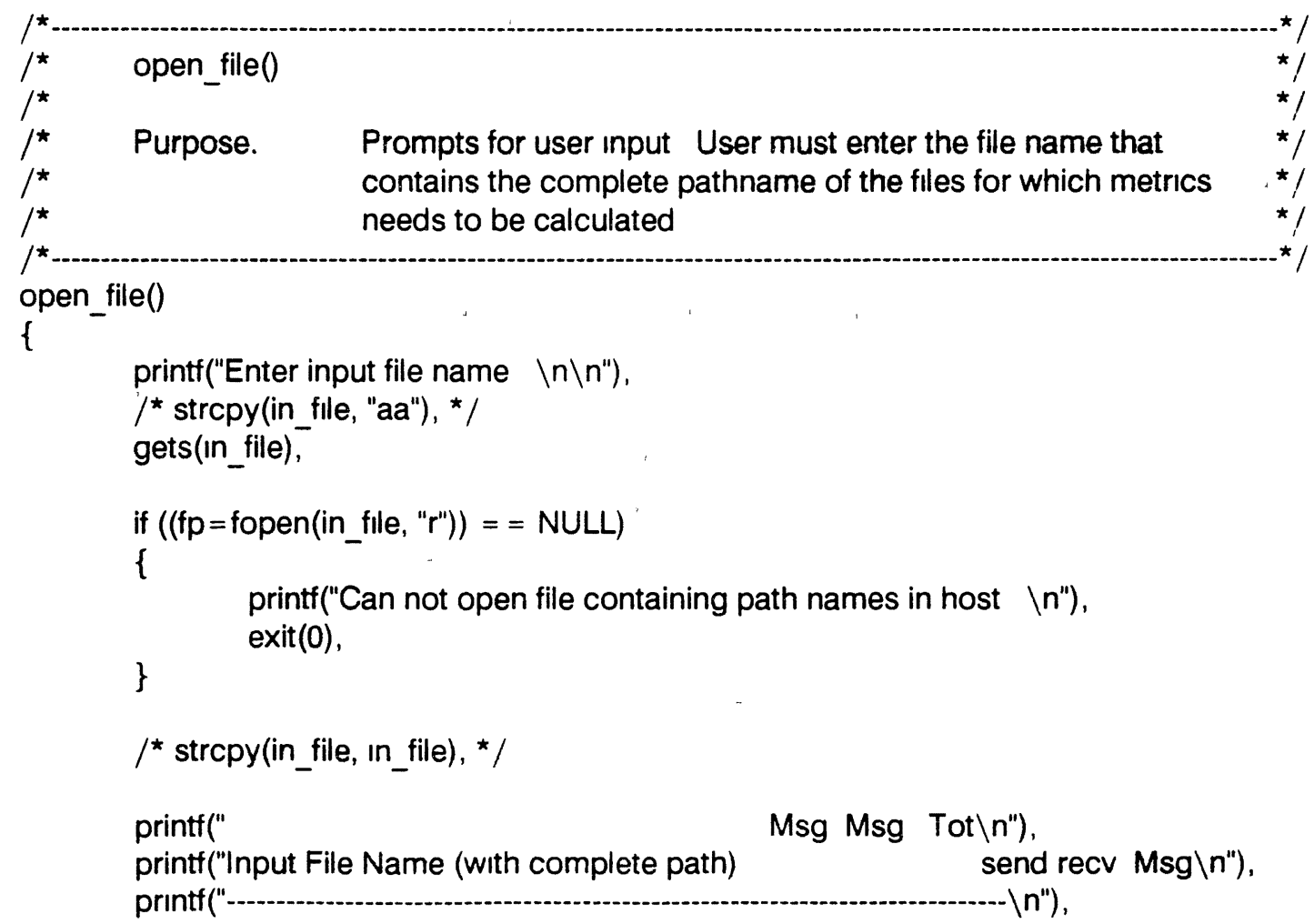




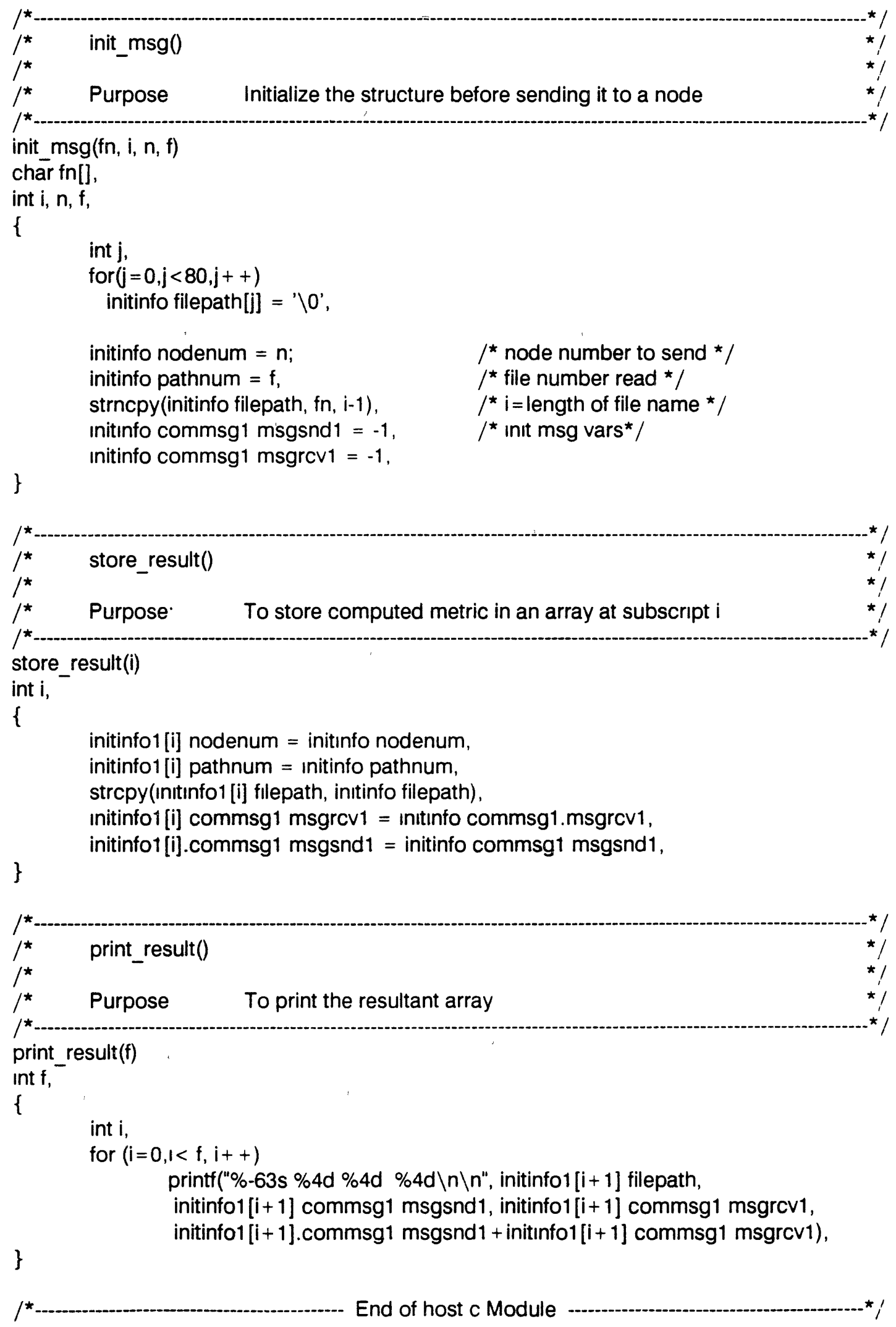




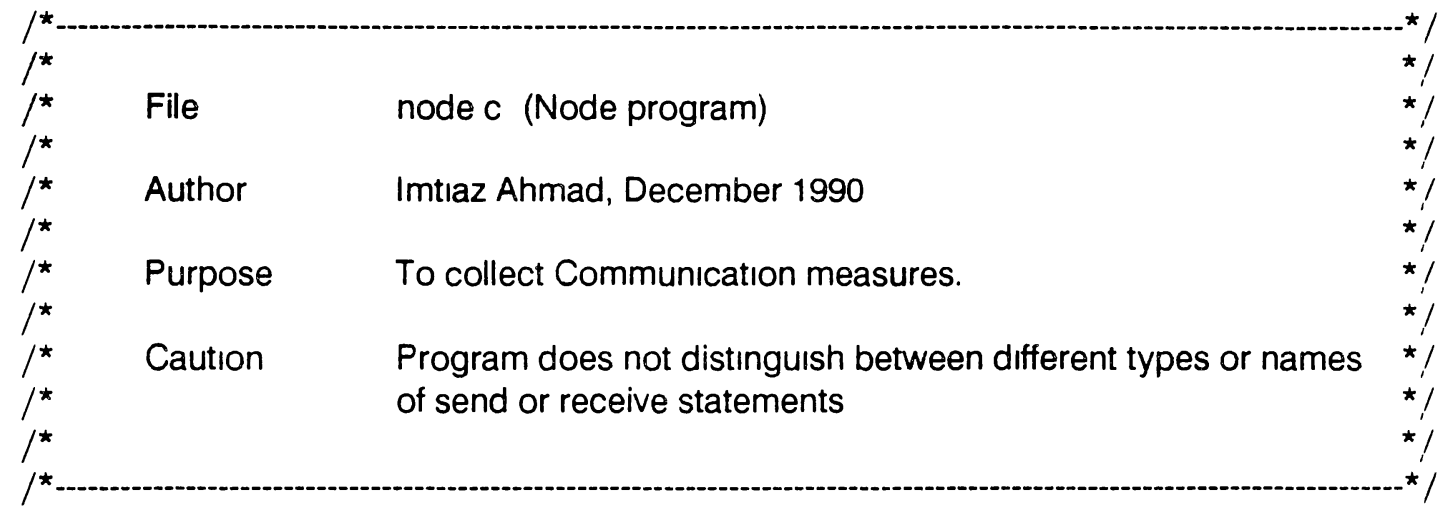

\#include <stdio.h> \#include <cube.h> \#include "node h" $/$ * defines states, classes and state tables */

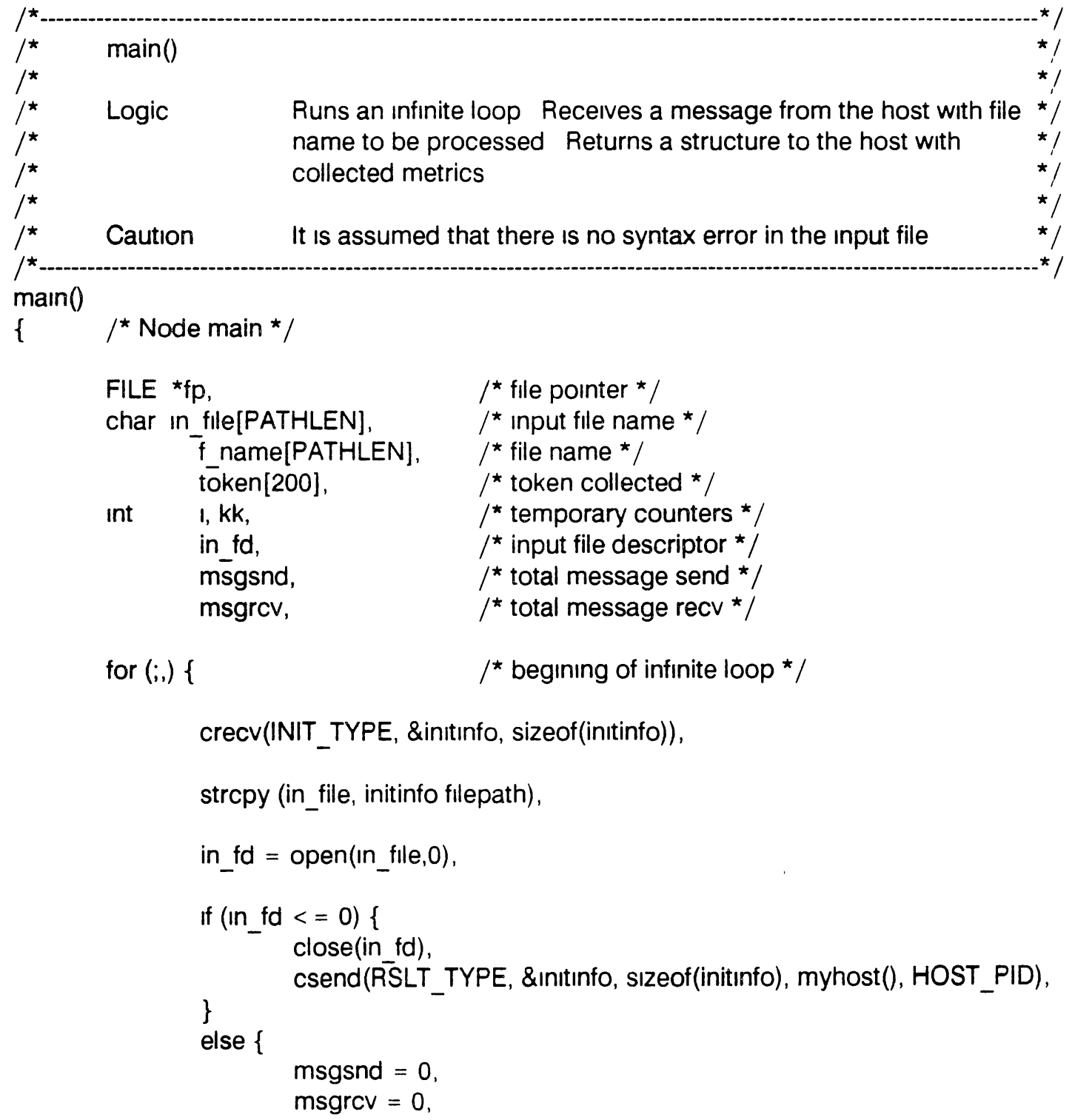


while $($ get_tok $($ in_fd, token $)==$ VALID_TOKEN $)\{$

switch ( kk= token_type (token) ) \{

case CSEND

msgsnd ++ ,

break,

case CRECV

msgrcv ++ ,

break,

default

break,

\} $/{ }^{*}$ end switch */

\} $/^{*}$ end while get_tok ()$* /$

$/$ * save necessary info before sendıng it back to host * /

initinfo nodenum $=$ mynode $($ ),

ınitınfo commsg1 msgsnd1 = msgsnd,

initınfo commsg1 msgrcv1 = msgrcv;

csend(RSLT_TYPE, \&initinfo, sizeof(initinfo), myhost(), HOST_PID),

\} $/{ }^{*}$ end else * close(in fd),

\}$/ *$ end infınite for loop */

\}$/ *$ end Node main */

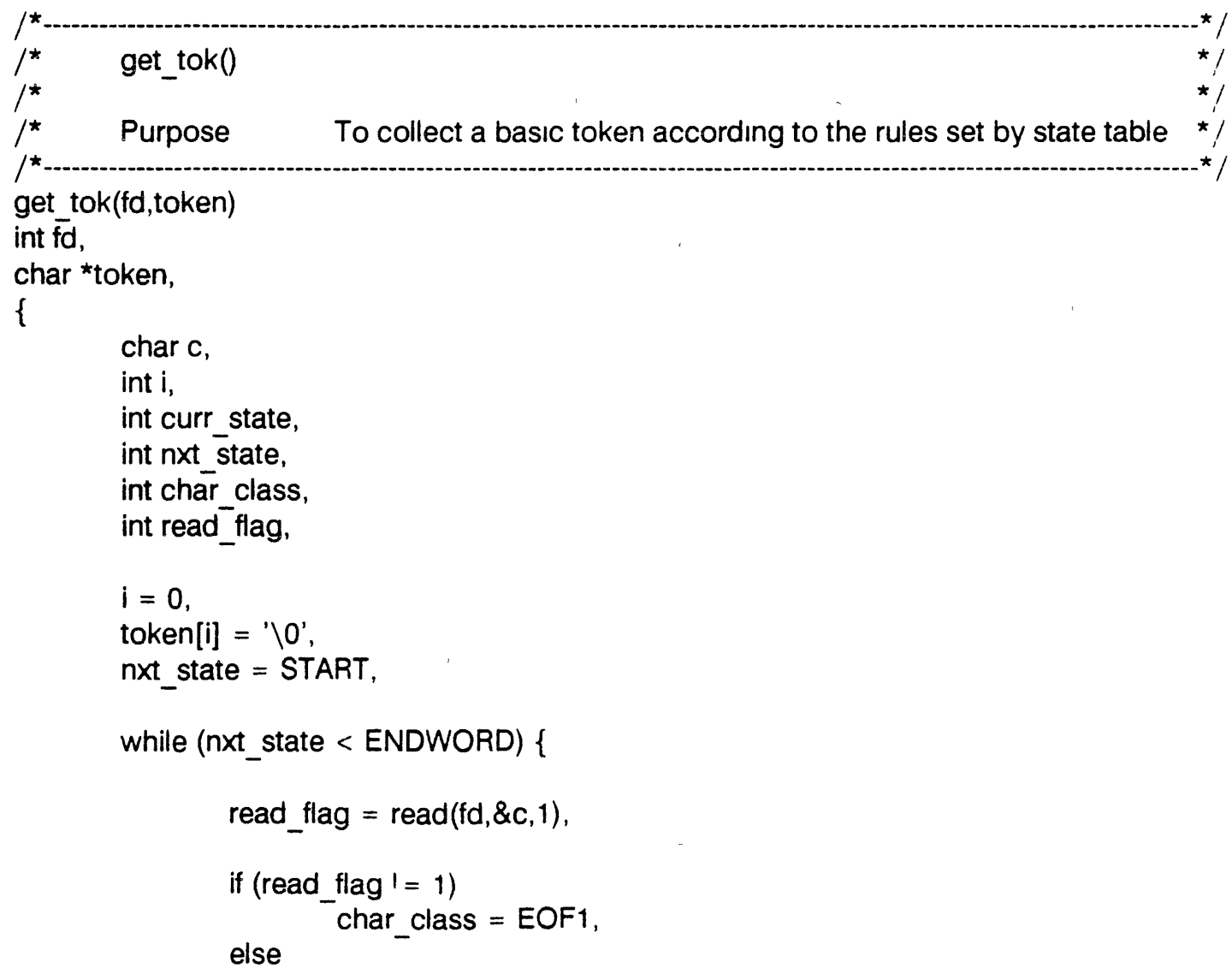




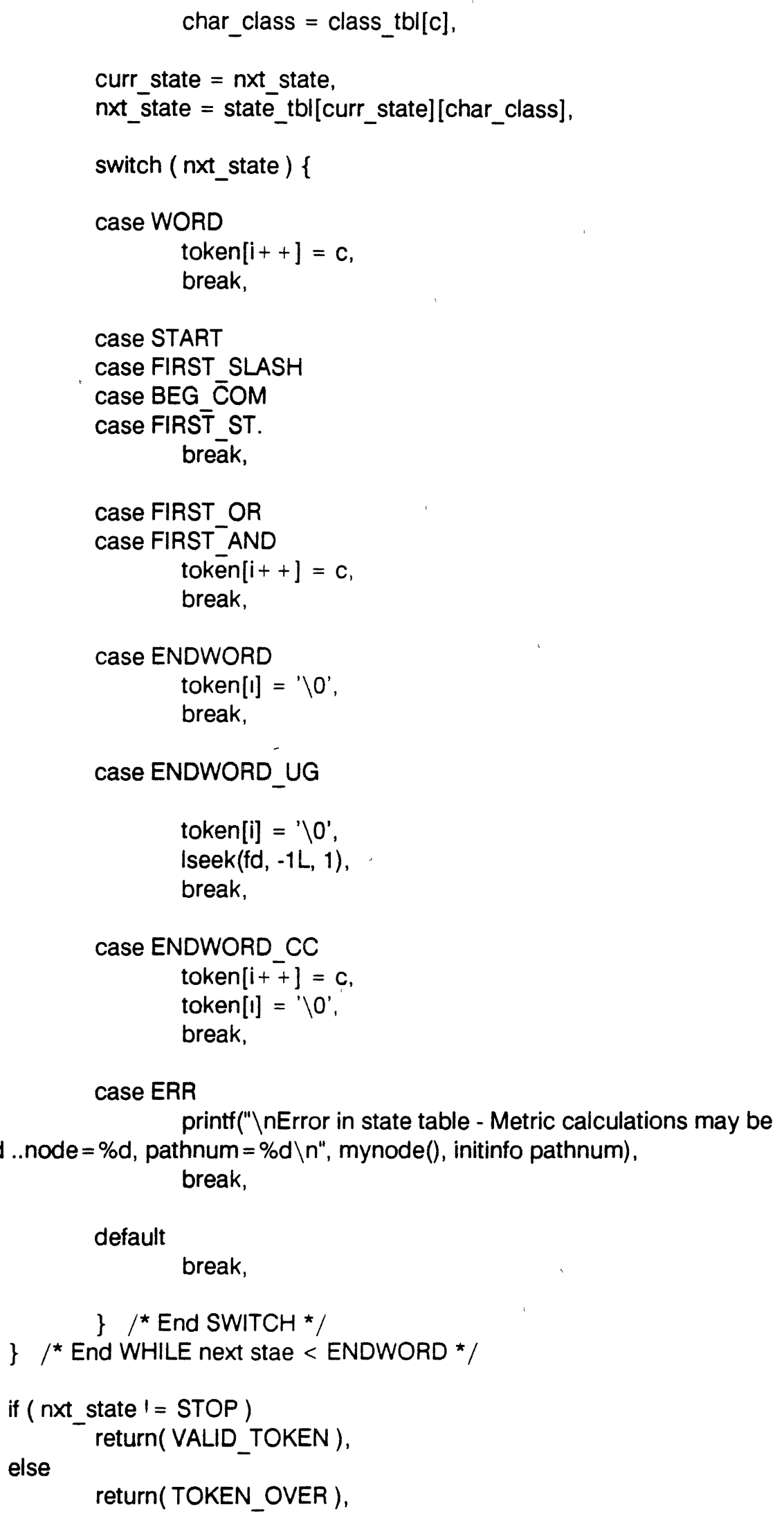

printf(" $\backslash n$ Error in state table - Metric calculations may be break,

default

break,

\} $/$ * End SWITCH */

\} $/$ * End WHILE next stae < ENDWORD */

return( VALID_TOKEN),

return( TOKEN_OVER), effected.. node $=\% d$, pathnum $=\% d \backslash n "$, mynode(), initinfo pathnum),

if ( $n \times t$ state $1=$ STOP )

else 


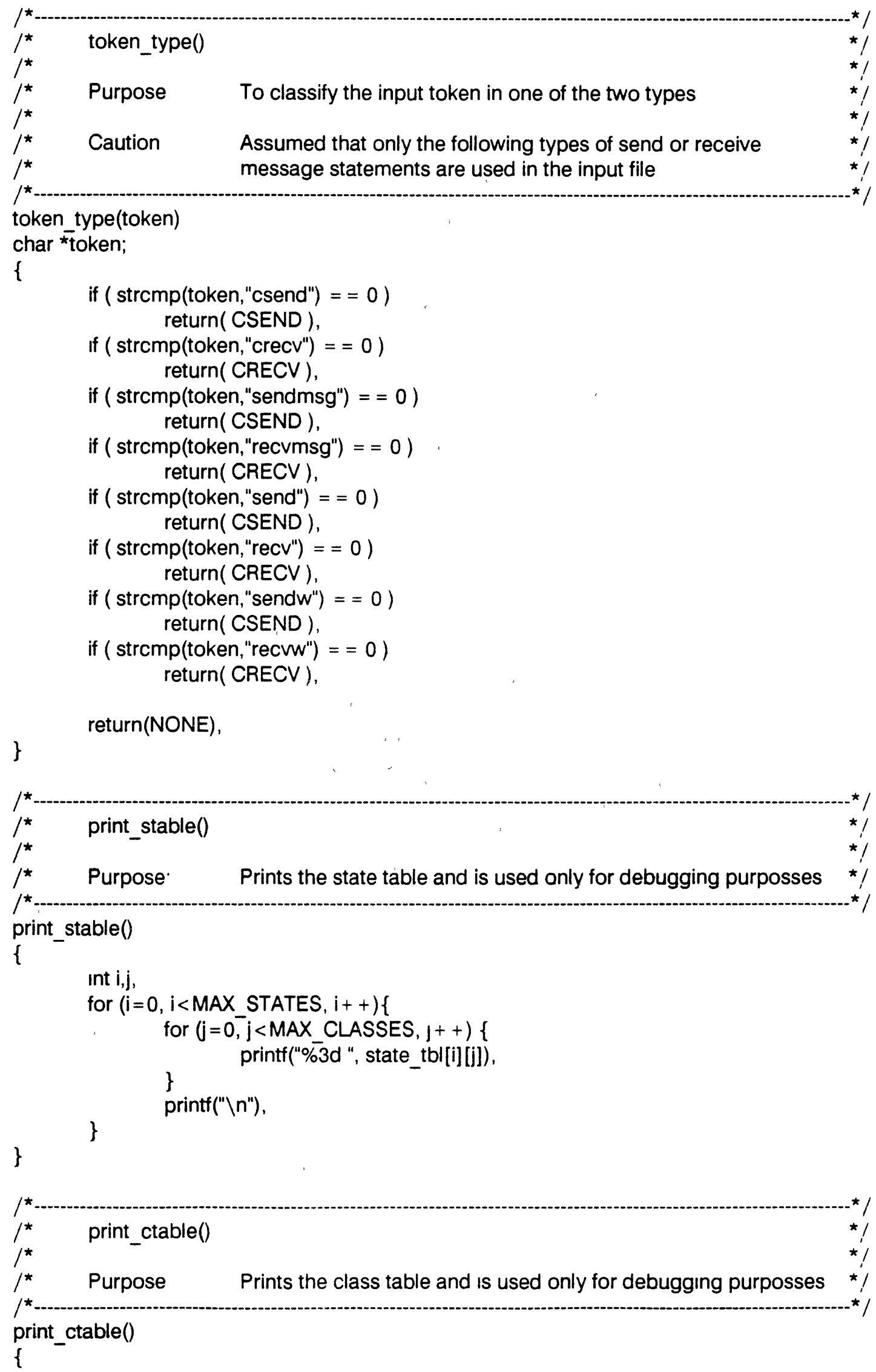




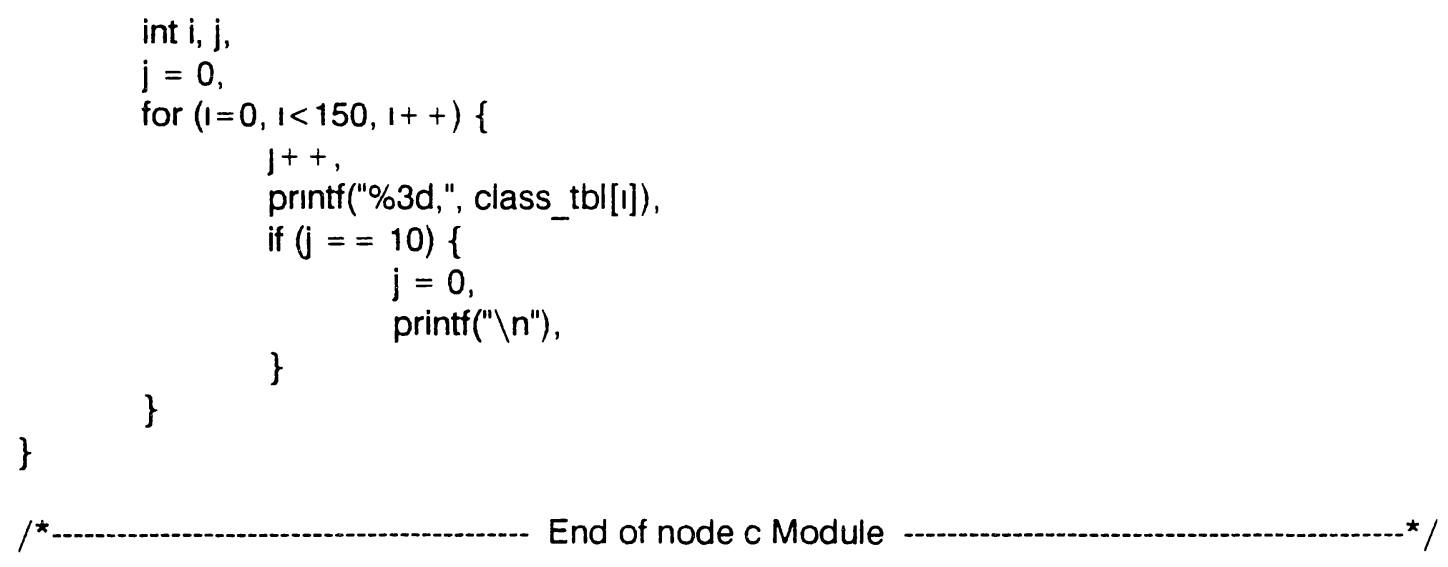




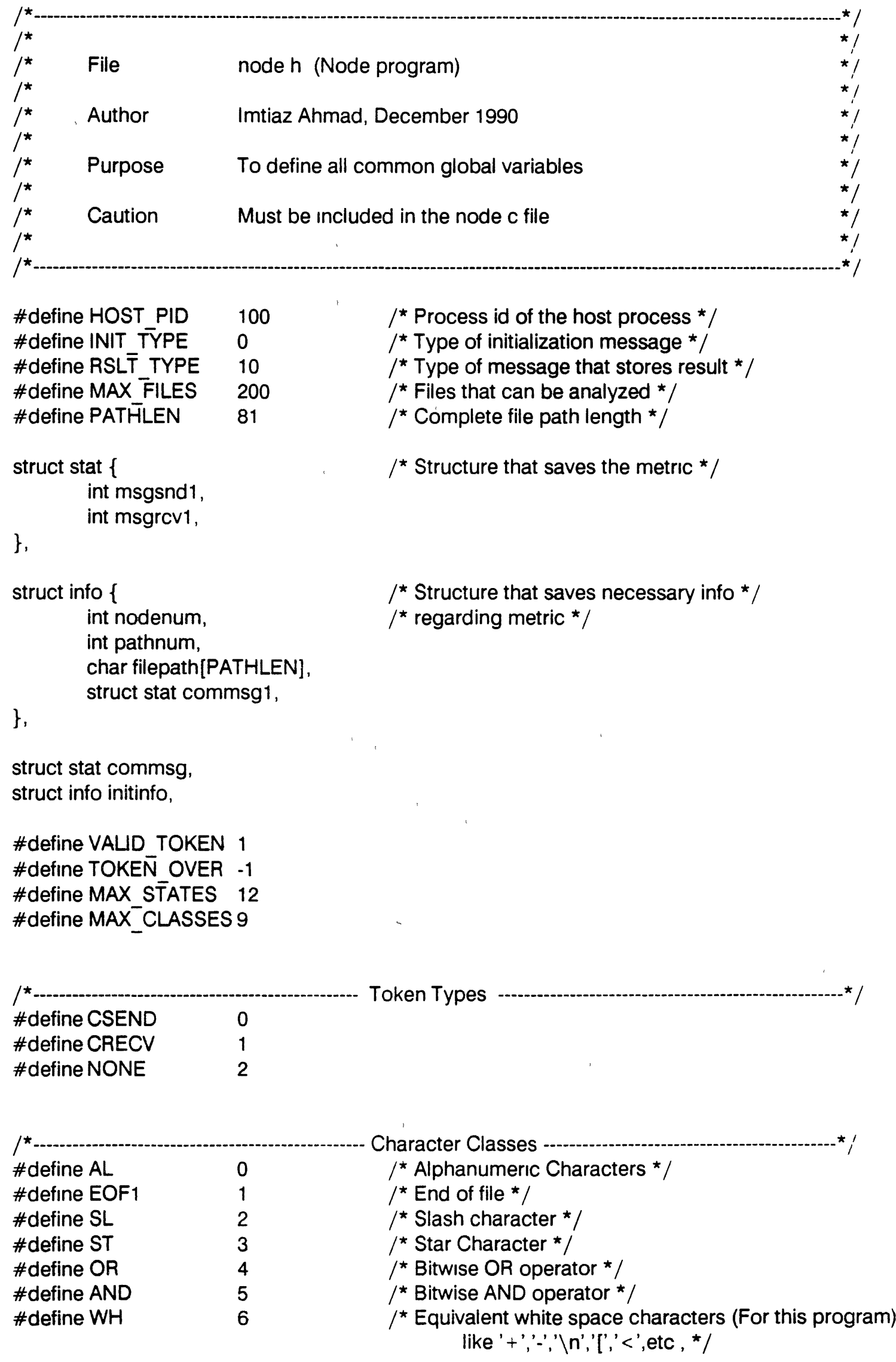




\begin{tabular}{|c|c|c|}
\hline $\begin{array}{l}\text { \#define QN } \\
\text { \#define ILL }\end{array}$ & $\begin{array}{l}7 \\
8\end{array}$ & $\begin{array}{l}/ * \text { Question mark */ } \\
/ * \text { Illegal characters * / }\end{array}$ \\
\hline \multicolumn{3}{|l|}{$/^{\star}$} \\
\hline \#define START & 0 & $/{ }^{*}$ Start state, Begın to collect a token * / \\
\hline \#define WORD & 1 & $/ *$ Collecting a token $* /$ \\
\hline \#define FIRST_SLASH & 2 & $\begin{array}{l}/^{*} \text { There is a slash, maybe this is a begin } \\
\text { comment mark }{ }^{\star} /\end{array}$ \\
\hline \#define BEG_COM & 3 & ${ }^{*}$ Yes This is a begin comment mark ${ }^{*} /$ \\
\hline \#define FIRST̄_ST & 4 & $\begin{array}{l}{ }^{*} \text { There is a star Maybe this is the end } \\
\text { comment mark * / }\end{array}$ \\
\hline \#define FIRST_OR & 5 & $\begin{array}{l}/^{*} \text { There is an OR operator. See if there is } \\
\text { one more OR operator to make it a token * / }\end{array}$ \\
\hline \#define FIRST_AND & 6 & $\begin{array}{l}/ * \text { There is an AND operator. See if there is } \\
\text { one more AND operator to make it a token */ }\end{array}$ \\
\hline \#define ENDWORD & 7 & $/{ }^{*}$ Collected a token $* /$ \\
\hline \#define ENDWORD_UG & & $/ *$ Collected a token, Unget last char */ \\
\hline \#define ENDWORD_CC & & $\begin{array}{l}/ \text { * Collected a token, Add the last character } \\
\text { read, to the token } * /\end{array}$ \\
\hline \#define STOP & 10 & $/{ }^{*}$ End of file reached $* /$ \\
\hline \#define ERR & 11 & $/{ }^{\star}$ Error in state table */ \\
\hline
\end{tabular}

$/ *$ Character Class Table

int class_tbl []$=\{$

\begin{tabular}{|c|c|c|c|c|c|c|c|c|c|}
\hline ILL, & ILL, & ILL, & ILL, & ILL, & ILL, & ILL, & ILL, & ILL, & $\mathrm{WH}$, \\
\hline WH, & ILL, & ILL, & WH, & ILL, & ILL, & ILL, & ILL, & ILL, & ILL, \\
\hline ILL, & ILL, & ILL, & ILL, & ILL, & ILL, & ILL, & ILL, & ILL, & ILL, \\
\hline ILL, & ILL, & $\mathrm{WH}$, & WH, & $W H$, & $\mathrm{WH}$, & $W H$, & WH, & AND, & $W H$, \\
\hline $\mathrm{WH}$, & $W H$, & ST, & WH, & WH, & WH, & WH, & SL, & $A L$, & $A L$ \\
\hline$A L$, & $A L$, & $A L$, & $A L$, & $A L$, & $A L$, & $A L$, & $A L$, & $\mathrm{WH}$, & $W H$, \\
\hline WH, & WH, & WH, & QN, & WH, & $A L$ & $A L$, & $A L$ & $A L$, & $A L$, \\
\hline$A L$ & $\mathrm{AL}$ & $\mathrm{AL}$ & AL, & $\mathrm{AL}$ & AL, & $\mathrm{AL}$ & $A L$, & $\mathrm{AL}$, & $A L$, \\
\hline AL, & $\mathrm{AL}$, & $A L$ & $A L$, & $A L$, & $A L$, & $A L$ & $A L$ & $A L$, & AL, \\
\hline$A L$, & $W H$, & $W H$, & WH, & WH, & $\mathrm{WH}$, & WH, & $A L$, & $A L$, & $A L$, \\
\hline L, & $A L$, & $A L$, & $A L$, & $A L$, & $A L$, & $A L$, & $A L$, & $A L$, & $A L$, \\
\hline $\mathrm{L}$, & $A L$, & $A L$, & $A L$, & $A L$, & $A L$, & $A L$, & $A L$ & $A L$ & $A L$ \\
\hline L, & $A L$, & $A L$ & $W H$, & OR, & WH, & $\mathrm{WH}$, & ILL, & ILL, & ILL, \\
\hline LL, & ILL, & ILL, & ILL, & ILL, & ILL, & ILL & ILL, & ILL, & ILL, \\
\hline ILL, & ILL, & ILL, & ILL, & ILL, & ILL, & ILL, & ILL, & ILL, & ILL, \\
\hline LL, & ILL, & ILL, & ILL, & ILL, & ILL, & ILL, & ILL, & ILL, & ILL, \\
\hline LL, & ILL, & ILL, & ILL, & ILL, & ILL, & ILL, & ILL, & ILL, & ILL, \\
\hline LL, & ILL, & ILL, & ILL, & ILL, & ILL, & ILL, & ILL, & ILL, & ILL, \\
\hline LL, & ILL, & ILL, & ILL, & ILL, & ILL, & ILL, & ILL, & ILL, & ILL, \\
\hline ILL & ILL, & ILL, & ILL, & ILL, & ILL, & ILL, & ILL, & ILL, & ILL, \\
\hline ILL & ILL, & ILL & ILL, & ILL, & ILL, & ILL, & ILL, & ILL, & ILL, \\
\hline ILL, & ILL, & ILL, & ILL, & ILL, & ILL, & ILL, & ILL, & ILL, & ILL, \\
\hline ILL & ILL, & ILL, & ILL, & ILL, & ILL, & ILL, & ILL, & ILL, & ILL, \\
\hline ILL & ILL, & ILL & ILL, & ILL & ILL, & ILL, & ILL, & ILL, & ILL, \\
\hline ILL & ILL, & ILL & ILL, & ILL, & ILL, & ILL, & ILL, & ILL, & ILL \\
\hline
\end{tabular}


\}

$/ *$

State Table

int state_tbl[MAX_STATES][MAX_CLASSES] $=\{$

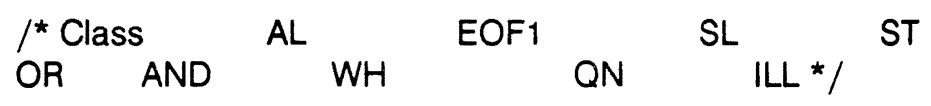

/*Token $* /$

/*START* / WORD, STOP, FIRST SLASH, START, FIRST_OR, FIRST_AND, START, ENDWWORD_CC, ERR,

/*WORD* / WORD, ENDWORD, FIRST_SLASH, ENDWORD, ENDWORD_UG, ENDWORD_UG, ENDWORD, ENDWORD_UG, ERR,

/*FIRSTSLASH* / ENDWORD UG, ENDWORD, ENDWORD UG, BEG COM,

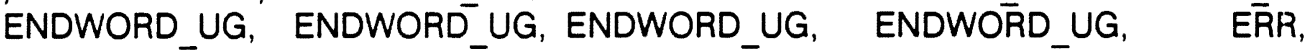

/*BEG $\mathrm{COM}^{*} /$ BEG_COM, ERR, BEG_COM, FIRST_ST, BEG_COM, BEG_COOM, BEG_COM, BËG_COM, ERT,

/*FIRST STAR* / BEG_COM, ERR, ENDWORD, FIRST_ST, BEG_COM, BEG_COOM, BEG_COM, BEG_COM, ERR,

$/{ }^{\star}$ FIRST OR* $/$ ENDWORD UG, ERR, ENDWORD UG, ENDWORD UG, ENDWORD_CC, ENDWORD_UG, ENDWORD_UG, ENDDWORD_UG, ERTR,

/*FIRST AND* / ENDWORD UG, ERR, ENDWORD_UG, ENDWORD_UG, ENDWORD_UG, ENDWORD_CC, ENDWORD_UG, ENDWORD_UG, ERR

\} , 
APPENDIX G

INTER-METRIC CORRELATION ANALYSES 
Correlation Analysis

10 WITH' Variables HEXELNS HBLKLNS HCMTLNS NEXELNS NBLKLNS NCMTLNS TEXELNS TBLKLNS TCMTLNS TOTLNS Simple Statistics

\begin{tabular}{|c|c|c|c|c|c|c|c|c|c|c|c|}
\hline Variable & $\mathrm{N}$ & & Mean & & ta Dev & & Median & & Uinımum & & Maximum \\
\hline HEXELNS & 18 & 118 & 444444 & 73 & 807558 & 97 & 500000 & 29 & 000000 & 253 & 000000 \\
\hline HBLKLNS & 18 & 34 & 777778 & 19 & 028015 & 36 & 000001 & 8 & 000000 & 84 & 000000 \\
\hline HCMTLNS & 18 & 94 & 833333 & 69 & 959862 & 62 & 500000 & 20 & 000000 & 233 & 000000 \\
\hline NEXELNS & 18 & 277 & 944444 & 204 & 744453 & 206 & onouor) & 58 & 000000 & 795 & 000000 \\
\hline NBLLLNS & 18 & 75 & 500000 & 59 & 602852 & 49 & 000000 & 12 & 000000 & 228 & 000000 \\
\hline NCMTLNS & 18 & 246 & 722222 & 170 & 113044 & 283 & 500000 & 64 & 000000 & 600 & 000000 \\
\hline TEXELNS & 18 & 393 & 000000 & 239 & 235301 & 361 & 500000 & 99 & 000000 & 884 & 000000 \\
\hline TBLKLNS & 18 & 108 & 555556 & 73 & 533684 & 90 & 000000 & 25 & 000000 & 312 & 000000 \\
\hline TCMTLNS & 18 & 337 & 555556 & 212 & 931975 & 329 & 500000 & 93 & 000000 & 721 & 000000 \\
\hline TOTLNS & 18 & 839 & 111111 & 446 & 659087 & 1003 & .000000 & 231 & 000000 & 1427 & 000000 \\
\hline Q5 & 18 & 13 & 000000 & 1 & 455214 & 14 & 000000 & 10 & 000000 & 14 & 000000 \\
\hline 06 & 18 & 13 & 055556 & 1 & 696787 & 14 & 000000 & 10 & 000000 & 15 & 000000 \\
\hline 07 & 18 & 14 & 444444 & $i$ & 199128 & 15 & 000000 & 12 & 000000 & 16 & 000000 \\
\hline QB & 18 & 14 & 166667 & $i$ & 424574 & 15 & 000000 & 12 & 000000 & 16 & 000000 \\
\hline Q9 & 18 & 10 & 888889 & 3 & 027111 & 10 & 000000 & 5 & 000000 & 16 & 000000 \\
\hline 010 & 18 & 4 & 222222 & 1 & 437136 & 4 & 000000 & 3 & 000000 & 8. & .000000 \\
\hline
\end{tabular}

\footnotetext{
Spearman Correlation Coefficients / Prob $>|R|$ under Ho Rno $=0 / N=18$
}

HEXELNS

HBLKLNS

HCMTLNS

NEXELNS

NBLKLNS

NCMTLNS

TEXELNS

TBLKLNS

TCMTLNS
$-0 \quad 00707$
$0 \quad 9778$

-0.22642
03663

-022872
0.3613

$0 \quad 45567$
$0 \quad 0574$

$-0 \quad 44777$
$0 \quad 0624$

$-0 \quad 61274$
$0 \quad 0069$

$-0 \quad 26513$
$0 \quad 2877$

$-0 \quad 31564$
$0 \quad 2020$

$-0 \quad 60301$

0008

$0 \quad 02120$

$-0 \quad 42803$
$0 \quad 0764$

28346
$0 \quad 2544$

$0 \quad 46080$
$0 \quad 0543$

$-0 \quad 55808$
$0 \quad 0161$

0 32541

$-0 \quad 39802$
$0 \quad 1019$

$-0 \quad 54927$

$-0 \quad 09666$

Q9

$-0 \quad 23806$
$0 \quad 3415$

-0.21364
$0 \quad 3947$

$-0 \quad 20220$
$0 \quad 4210$

$0 \quad 16694$
$0 \quad 5079$

$-0 \quad 51854$

$-0 \quad 43659$
$0 \quad 0701$

$-0 \quad 43795$
$0 \quad 0691$

$0 \quad 46359$
$0 \quad 0527$

028196
$0 \quad 2570$

$0 \quad 32235$

$-027611$

$-0 \quad 48182$
$0 \quad 0429$

$-0 \quad 56770$
$0 \quad 0140$

$0 \quad 62347$
$0 \quad 0057$

$0 \quad 13025$
$0 \quad 6064$

$-0 \quad 58409$

$-0 \quad 68935$

073250

$-0 \quad 45875$
$0 \quad 0555$

0.0109

00016

$0 \quad 0005$

$-0 \quad 56538$
$0 \quad 0145$

$-0 \quad 34091$

$-0 \quad 36328$

0 39521

$-0 \quad 38436$

$-0 \quad 41797$
$0 \quad 0843$

$-0 \quad 47192$
$0 \quad 0480$

$0 \quad 54824$
$0 \quad 0185$

-043621
$0 \quad 0703$

$-0 \quad 57697$
$0 \quad 0122$

$-0 \quad 68178$

0 73212

$0 \quad 56509$

$-0 \quad 11358$

- 008550

00006

$0 \quad 21067$

$0 \quad 15664$
$0 \quad 5348$

$0 \quad 21067$
$0 \quad 4014$ 


\section{Correlation Analysis}

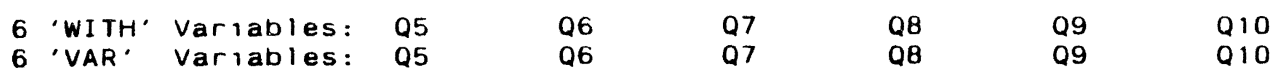

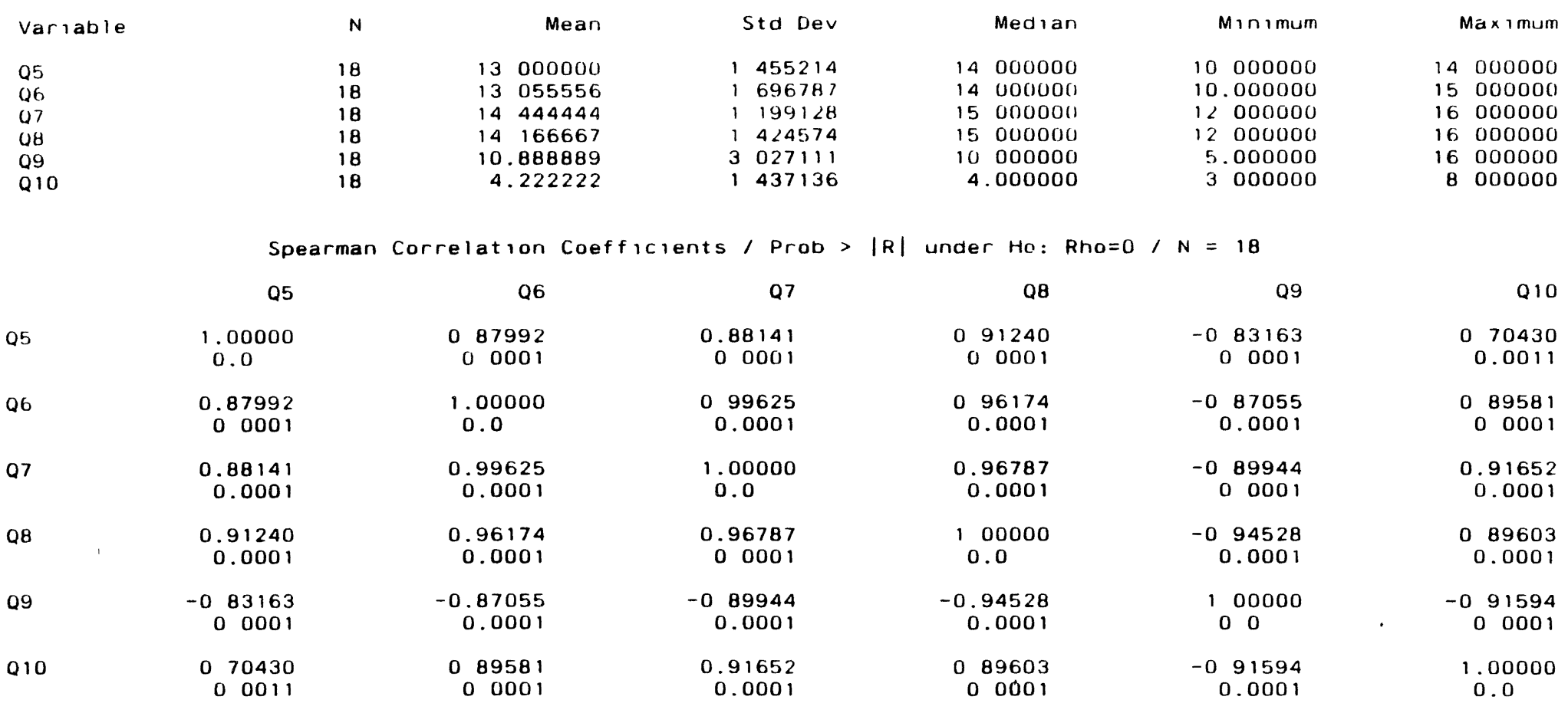


CORRELATIONS BETWEEN SUBJECTS' REPLIES AND SIZE MEASUREMENTS

\section{Correlation Analysis}

Spearman Correlation Coefficients / Prob $>|R|$ under Ho: Rho=0/ $N=18$

Q5

TOTLNS

$-0.23685$
Q6

03440

$-0 \quad 38230$

$0 \quad 1174$
Q7

Q9

Q10

$-0.40000$

0.1000

-0 41994

0.0827

0 49742

$0 \quad 0357$

$-0 \quad 47611$

0.0458 


\begin{tabular}{|c|c|c|c|c|c|c|c|c|c|c|c|c|c|}
\hline $\begin{array}{l}17 \text { 'WITH' } \\
6 \text { 'VAR' }\end{array}$ & $\begin{array}{l}\text { Variables } \\
\text { Variables. }\end{array}$ & $\begin{array}{l}\text { HUN1 } \\
\text { TUN 1N2 } \\
\text { Q5 }\end{array}$ & $\begin{array}{l}\text { HUN2 } \\
\text { TCAPN } 1 \\
06\end{array}$ & $\begin{array}{l}\text { HCAPN1 } \\
\text { TCAPN2 } \\
\text { Q7 }\end{array}$ & $\begin{array}{l}\text { HCAPN2 } \\
\text { TCAPN IN2 } \\
\text { Q8 }\end{array}$ & $\begin{array}{l}\text { HEFRT } \\
\text { TEFRT } \\
\text { Q9 }\end{array}$ & $\begin{array}{l}\text { NUNI } \\
\text { Q10 }\end{array}$ & \multicolumn{2}{|c|}{ NUN2 } & NCAPN 1 & NCAPN2 & \multicolumn{2}{|l|}{ NEFRT } \\
\hline \multicolumn{14}{|c|}{ Simple Statistics } \\
\hline & Variable & & N & & Mean & Sta & Dev & & Median & & Minimum & & Maximum \\
\hline & HUN 1 & & 18 & 375 & 555556 & $11642 E$ & 933 & 35 & 000000 & & 23000000 & 61 & 1000000 \\
\hline & HUN2 & & 18 & 558 & 888889 & 258408 & 891 & 54 & 500000 & & 190000001 & 113 & 3000000 \\
\hline & HCAPN 1 & & 18 & 3389 & 944444 & $225 \quad 1238$ & 800 & 249 & 000000 & & 69000000 & 827 & 7000000 \\
\hline & HCAPN2 & & 18 & 1807 & 777778 & 122.758 & 757 & 143 & 500000 & & 36000000 & 446 & 6.000000 \\
\hline & HEFRT & & 18 & & 302424 & 362 ! & 591 & & 129673 & & 12337 & & 1140590 \\
\hline & NUNI & & 18 & 44.5 & 500000 & 12.7013 & 320 & 46 & 000000 & & 27000000 & 73 & 3000000 \\
\hline & NUN2 & & 18 & 72.3 & 388889 & 40744 & 742 & 69 & 500000 & & 26.000000 & -190 & 0000000 \\
\hline & NCAPN 1 & & 18 & 942.2 & 222222 & 710.268 & 844 & 687 & 000000 & & 151000000 & 2565 & 5000000 \\
\hline & NCAPN2 & & 18 & 5918 & 833333 & 465.025 & 521 & 412 & .000000 & & 80000000 & 1608 & 8000000 \\
\hline & NEFRT & & 18 & & 813805 & 3679 & 114 & & 1054636 & & 56230 & & 13686523 \\
\hline & TUNI & & 18 & 82.0 & 055556 & 22367 & 182 & 83. & .000000 & & 50000000 & 134 & 4000000 \\
\hline & TUN? & & 18 & $128 .=$ & $\because 77778$ & 61622 & 003 & 127 & 000000 & & 56000000 & 303 & 3000000 \\
\hline & TUNIN2 & & 18 & 2103 & 333333 & 83223 & 300 & 211 & 500000 & & 106000000 & 437 & 000000 \\
\hline & TCAPN 1 & & 18 & 1281.1 & 166667 & 808.642 & 017 & 1193 & 500000 & & 274000000 & 2824 & 4.000000 \\
\hline & TCAPN2 & & 18 & 780.6 & 611111 & 511.298 & 978 & 720. & .500000 & & 142.000000 & 1764 & 4.000000 \\
\hline & TCAPN IN2 & & 18 & 2061.7 & 777778 & 1317.423 & 937 & 1889. & .000000 & & 416.000000 & 4588 & B 000000 \\
\hline & TEFRT & & 18 & & 209993 & 5339 & 407 & & 3614345 & & 180012 & & 18474019 \\
\hline & 05 & & 18 & 13.0 & 000000 & 1.455 & 214 & 14. & .000000 & & 10.000000 & 14 & 4000000 \\
\hline & 06 & & 18 & 13.0 & 055556 & 1.696 & 787 & 14 & 000000 & & 10000000 & 15 & 5000000 \\
\hline & 07 & & 18 & 14.4 & 444444 & 1.199 & 128 & 15 & 000000 & & 12.000000 & & 6.000000 \\
\hline & $\mathrm{QB}$ & & 18 & 14.1 & 166667 & 1.424 & 574 & 15 & 000000 & & 12.000000 & & 6.000000 \\
\hline & 09 & & 18 & 108 & 888889 & 3.027 & 111 & 10. & .000000 & & 5000000 & 16 & 6000000 \\
\hline & 010 & & 18 & 4.2 & 222222 & 1.437 & 136 & 4. & .000000 & & 3.000000 & & . 000000 \\
\hline
\end{tabular}

Spearman Correlation Coefficients / Prob $>|R|$ under Ho Rho=0/ $N=18$

HCAPN 1 
Correlation Analysis

Spearman Correlation Coefficients / Prob > $|R|$ under Ho: Rho=0/N=18

$\begin{array}{lr}\text { NUN2 } & -0.40514 \\ \text { NCAPN1 } & 00953 \\ \text { NCAPN2 } & 04112 \\ \text { NEFRT } & 0385 \\ & 0.0240 \\ \text { TUN1 } & -054765 \\ & 00186 \\ \text { TUN2 } & -0.18373 \\ & 04655 \\ \text { TUN1N2 } & -030268 \\ & 02221 \\ \text { TCAPN1 } & -026527 \\ & 0.2874 \\ \text { TCAPN2 } & -0.41810 \\ & 0.0842 \\ \text { TCAPN1N2 } & -046403 \\ & 0.0524 \\ \text { TEFRT } & -0.44519 \\ & 00641 \\ & -042634 \\ & 0.0777\end{array}$

Q6

-039575
0.1040
$-0 \quad 52993$
0.0237
$-0 \quad 54244$
$0 \quad 0200$
$-0 \quad 55950$
0.0158
-0.32751
0.1846
$-0 \quad 38892$
0.1107
-0.36200
0.1399
-0.46739
0.0505
-0.50719
0.0317
-0.49013
0.0389
-0.47307
0.0474

\begin{abstract}
Q7
\end{abstract}

-0.41797
0.0843
$-0 \quad 54972$
$0 \quad 0181$
$0 \quad 56315$
$0 \quad 0149$
-058152
0.0114
-0.33619
0.1726
-039979
$0 \quad 1002$
$-0 \quad 37065$
$0 \quad 1300$
-0.49066
0.0387
-0.52700
0.0246
$-0 \quad 51337$
0.0293
-049520
0.0367

Q8

-0.47636
0.0457
$-0 \quad 61738$
$0 \quad 0063$
$-0 \quad 64292$
$0 \quad 0040$
$-0 \quad 66401$
$0 \quad 0027$
$-0 \quad 32534$
0.1877
$-0 \quad 42750$
0.0768
-0.39182
0.1078
-056075
0.0155
-059628
$0 \quad 0090$
-0.58184
0.0113
-0.56075
$0 \quad 0155$

Q9

Q10

0.0942

$-0 \quad 53535$

$0 \quad 0220$

$-0 \quad 53535$

0.0220

$-0.55518$

- $0 \quad 35690$

0.1460

$0 \quad 36436$

$0 \quad 45970$

$0 \quad 0549$

$-0.39903$

0.1009

0. 42268

0.0805

$-0 \quad 36843$

0.1325

0.62996

0.0051

$-0.49569$

0.0364

$-0.51552$

0.0285

0.65039
0.0035

$-0 \quad 51552$
$0 \quad 0285$

0.65039

$0 \quad 0035$

00285

$0 \quad 63337$

$-049569$ 


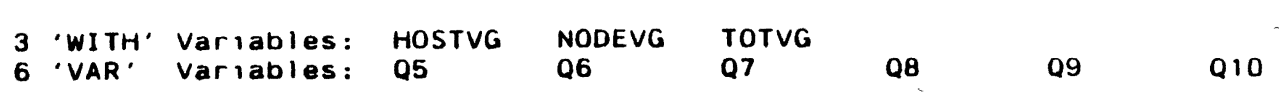

Variable
HOSTVG
NODEVG
TOTVG
Q5
Q6
Q7
Q8
Q9
Q10

Sta Dev

14455702
49.413025
53.198727
1.455214
1.696787
1.199128
1.424574
3.027111
1.437136

\section{Median}

7.000000 35.000000 525000001 14000000 14.000000 15.000000 15.000000 10.000000
4.000000

\section{Minimum}

2000000

6000000

11000000

$\begin{array}{ll}11 & 000000 \\ 10 & 000000\end{array}$

10.000000

12.000000

12.000000

5.000000

3.000000
Max I mum

47000000 152000000 158000000 14.000000 15.000000 16.000000 16.000000 16.000000

Spearman Correlation Coefficients / Prob $>|R|$ under Ho: Rho=0/ $N=18$

Q5

$-0.53053$

$-0.39259$

-0.09164
0.7176

$-0.55837$

07

\begin{abstract}
-0.06864
0.7867
\end{abstract}
-0 58439

$-0.46047$
Q8

-0.02461
09228
-0.65081
0.0034
-0.53409
0.0224

0.0224
09

$-0.01029$

0.9677
0.73288

0.73288

$0 \quad 61016$

061016
0.0072
Q10

$-0 \quad 08364$ 0.7414

$-0.59545$

$-0 \quad 49621$
4 


\section{Correlation Analysis}

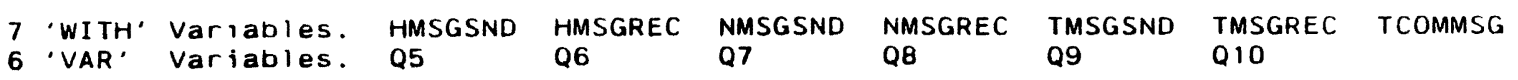

Simple Statistics

\begin{tabular}{|c|c|c|c|c|c|c|}
\hline Variable & $N$ & Mean & Std Dev & Median & Minimum & Maximum \\
\hline HMSGSND & 18 & 4.277778 & 2803476 & 4.500000 & 0 & 9000000 \\
\hline HMSGREC & 18 & 2.611111 & 1144752 & 2000000 & 1.000000 & 5000000 \\
\hline NMSGSND & 18 & 8.888889 & 6.641128 & 9000000 & 2.000000 & 32000000 \\
\hline NMSGREC & 18 & 10555556 & 6.921596 & 10.000000 & 2.000000 & 33000000 \\
\hline TMSGSND & 18 & $13 \quad 166667$ & 7270003 & 13.000000 & 3.000000 & 35.000000 \\
\hline TMSGREC & 18 & 13.166667 & 7.196813 & 13.000000 & 3.000000 & 35.000000 \\
\hline TCOMMSG & 18 & 26333333 & 14.418126 & 27.000000 & 6000000 & 70.000000 \\
\hline Q5 & 18 & 13000000 & 1455214 & 14.000000 & 10.000000 & 14.000000 \\
\hline Q6 & 18 & 13055556 & 1.696787 & 14.000000 & 10.000000 & 15000000 \\
\hline 07 & 18 & 14.444444 & 1199128 & 15.000000 & 12.000000 & 16.000000 \\
\hline Q8 & 18 & $14 \quad 166667$ & 1.424574 & 15.000000 & 12.000000 & 16.000000 \\
\hline 09 & 18 & 10888889 & 3027111 & 10.000000 & 5.000000 & 16.000000 \\
\hline Q10 & 18 & 4. 222222 & 1437136 & 4.000000 & 3.000000 & 8000000 \\
\hline
\end{tabular}

Spearman Correlation Coefficients / Prob > $|R|$ under Ho: Rho=0/N=18

$$
-0.22931
$$$$
\text { 0. } 3812
$$$$
-002843
$$

$$
\begin{array}{r}
-0.21355 \\
0.3949
\end{array}
$$$$
-0.26630
$$

$$
\begin{array}{r}
-0 \quad 14713 \\
0.5602
\end{array}
$$

$$
\begin{array}{r}
-0.26630 \\
0 \quad 2855
\end{array}
$$$$
-024673
$$

-0 27803

$$
0.2639
$$

$-0.28477$

$-0 \quad 34595$

$$
\begin{array}{r}
0 \quad 34595 \\
0.1597
\end{array}
$$

-0.27643
0.2668

0.1858$$
\begin{array}{r}
-0.23658 \\
0.3446
\end{array}
$$

$0 \quad 57827$

.22096

22096
0.3783

0.31165

0.38407

0.1156

0.35959

0.1427
-0.18121
04718

$-0.43963$

.24693

0.3232

$\begin{array}{ll}-0 & 33277\end{array}$

0.1772

$-0.30336$

$-0.34274$

0.1638 


\section{Correlation Analysis}

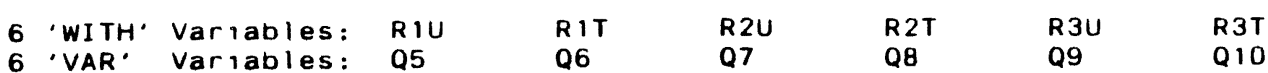

$\begin{array}{ll}\text { Variable } & N \\ \text { R1U } & 18 \\ \text { R 1T } & 18 \\ \text { R2U } & 18 \\ \text { R2T } & 18 \\ \text { R3U } & 18 \\ \text { R3T } & 18 \\ \text { Q5 } & 18 \\ \text { Q6 } & 18 \\ \text { Q7 } & 18 \\ \text { Q8 } & 18 \\ \text { Q9 } & 18 \\ \text { Q10 } & 18\end{array}$

$\begin{array}{rr} & \text { Mean } \\ 1342 & 900000 \\ 21311 \\ 1439 \\ 194444 \\ 21741 \\ 1238 \quad 461111 \\ 19770 \\ 13.000000 \\ 13.055556 \\ 14.444444 \\ 14.166667 \\ 10.888889 \\ 4222222\end{array}$

Simple Statistics

Std Dev

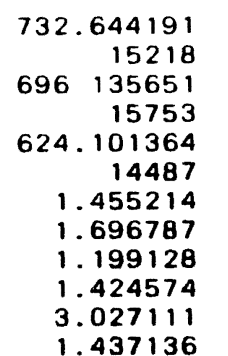

Median

1326050000 18777
$1424 \quad 650000$ 19021 1223250000 17229 14.000000 14.000000 15000000 15.000000 10.000000

Spearman Correlation Coefficients / Prob $>|R|$ under Ho: Rho=0/ $N=18$

\section{Q5}

Q6

$\begin{array}{lr}\text { R1U } & 0.02002 \\ \text { R1T } & 0.9371 \\ & -0.44519 \\ \text { R2U } & 0.0641 \\ & -0.26499 \\ \text { R2T } & 0.2879 \\ & -044519 \\ \text { R3U } & 0.0641 \\ & -0.26513 \\ \text { R3T } & 0.2877 \\ & -0.44519 \\ & 0.0641\end{array}$

-0.07278
0.7741
-0.49013
0.0389
-0.36845
0.1325
-0.49013
0.0389
-0.36182
0.1401
-049013
0.0389

Q7

-0.08178
0.7470
-0.51337
0.0293
-0.37708
0.1229
-0.51337
0.0293
-0.37045
0.1302
-0.51337
0.0293

Q8

-0.14768
0.5587
-0.58184
0.0113
-0.39752
0.1023
-0.58184
0.0113
-0.39161
0.1080
-0.58184
0.0113

Q9

0.17367

0.4907

0.65039

0.0035

0.43246

0.0731

$0 \quad 65039$

0.0035

0.42587

0.0780

0.65039
0.0035
Max ımum

3444500000
51397
$3409 \quad 300000$
53797
3022.500000
49388
14.000000
15.000000
16.000000
16.000000
16.000000
8.000000

$-0.08675$ 0.7322

$-0 \quad 51552$ 0.0285

$-0.37673$ 0.1233

$-0.51552$ 0.0285

$-0.36824$ 0.1327

-0.51552
0.0285 
Correlation Analysis

10 'WITH' Variables HEXELNS HBLKLNS HCMTLNS NEXELNS NBLKLNS NCMTLNS TEXELNS TBLKLNS TCMTLNS TOTLNS 'VAR' Variables, HEXELNS HBLKLNS HCMTLNS NEXELNS NBLKLNS NCMTLNS TEXELNS TBLKLNS TCMTLNS TOTLNS Simple Statistics

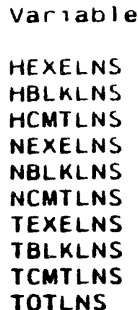

TCMTLNS
TOTLNS

$\begin{array}{lc} & \text { HEXELNS } \\ \text { HEXELNS } & \begin{array}{c}1.00000 \\ 0.0\end{array} \\ \text { HBLKLNS } & 0.84599 \\ 0.0001 & 0.67907 \\ \text { HCMTLNS } & 0.0019 \\ \text { NEXELNS } & 0.63120 \\ & 0.0050 \\ \text { NBLKLNS } & 0.50981 \\ & 00307 \\ \text { NCMTLNS } & 0.67562 \\ & 00021 \\ \text { TEXELNS } & 0.74342 \\ & 00004 \\ \text { TBLKLNS } & 0.53485 \\ & 0.0222 \\ \text { TCMTLNS } & 0.70418 \\ & 0.0011 \\ \text { TOTLNS } & 079029 \\ & 07001\end{array}$

(1)

$$
\text { Sta Dev }
$$

$73 \quad 807558$
19028015
69959862
204744453
59602852
170.113044
239235301
73.533684
212931975
$446 \quad 659087$

Median

97500000

36000000

62500000
206000000

49000000

283.500000

.

329500000

1003000000
Minimum

29000000

8000000

20000000

58000000

$\begin{array}{ll}12 & 000000 \\ 64 & 000000\end{array}$

99000000

25.000000

93000000

93000000
231000000
Maximum

253000000 84000000
233000000 79500000 795000000 228000000 884000000 840000 31210000 1427000000

Spearman Correlation Coefficients / Prob $>|R|$ under Ho Rho=0/ $N=18$

\begin{tabular}{|c|c|c|c|c|c|c|c|c|}
\hline HBLKLNS & HCMTLNS & NEXELNS & NBLKLNS & NCMTLNS & TEXELNS & TBLKLNS & TCMTLNS & TOTLNS \\
\hline $\begin{array}{r}0.84599 \\
0.0001\end{array}$ & $\begin{array}{r}0.67907 \\
0.0019\end{array}$ & $\begin{array}{r}0 \quad 63120 \\
0 \quad 0050\end{array}$ & $\begin{array}{r}050981 \\
0.0307\end{array}$ & $\begin{array}{r}067562 \\
0.0021\end{array}$ & $\begin{array}{r}0.74342 \\
0.0004\end{array}$ & $\begin{array}{r}053485 \\
0 \quad 0222\end{array}$ & $\begin{array}{r}070418 \\
0 \quad 0011\end{array}$ & $\begin{array}{r}079029 \\
0.0001\end{array}$ \\
\hline $\begin{array}{l}100000 \\
0.0\end{array}$ & $\begin{array}{r}044623 \\
0 \quad 0634\end{array}$ & $\begin{array}{r}075917 \\
0.0003\end{array}$ & $\begin{array}{r}070491 \\
0.0011\end{array}$ & $\begin{array}{r}058191 \\
0.0113\end{array}$ & $\begin{array}{r}085124 \\
0 \quad 0001\end{array}$ & $\begin{array}{r}074070 \\
0 \quad 0004\end{array}$ & $\begin{array}{r}0 \quad 52996 \\
0 \quad 0237\end{array}$ & $\begin{array}{r}0.89664 \\
0.0001\end{array}$ \\
\hline $\begin{array}{r}044623 \\
0.0634\end{array}$ & $\begin{array}{l}1.00000 \\
0.0\end{array}$ & $\begin{array}{r}0 \quad 08372 \\
0.7412\end{array}$ & $\begin{array}{r}-0.00413 \\
0.9870\end{array}$ & $\begin{array}{r}0.53333 \\
0.0227\end{array}$ & $\begin{array}{r}022521 \\
0.3689\end{array}$ & $\begin{array}{r}0 \quad 03616 \\
0.8867\end{array}$ & $\begin{array}{r}0 \quad 80475 \\
00001\end{array}$ & $\begin{array}{r}0.40052 \\
0.0995\end{array}$ \\
\hline $\begin{array}{r}0.75917 \\
0.0003\end{array}$ & $\begin{array}{r}0.08372 \\
0.7412\end{array}$ & $\begin{array}{l}100000 \\
00\end{array}$ & $\begin{array}{r}0.91632 \\
0.0001\end{array}$ & $\begin{array}{r}0.59556 \\
0.0091\end{array}$ & $\begin{array}{r}096231 \\
0 \quad 0001\end{array}$ & $\begin{array}{r}0.91275 \\
0 \quad 0001\end{array}$ & $\begin{array}{r}07997 \\
0 \quad 1199\end{array}$ & $\begin{array}{r}0.87862 \\
0.0001\end{array}$ \\
\hline $\begin{array}{r}070491 \\
0.0011\end{array}$ & $\begin{array}{r}-0 \quad 00413 \\
0 \quad 9870\end{array}$ & $\begin{array}{r}091632 \\
0 \quad 0001\end{array}$ & $\begin{array}{l}100000 \\
00\end{array}$ & $\begin{array}{r}060744 \\
0.0075\end{array}$ & $\begin{array}{r}0.85493 \\
0.0001\end{array}$ & $\begin{array}{r}099226 \\
0 \quad 0001\end{array}$ & $\begin{array}{r}35829 \\
0 \quad 1443\end{array}$ & $\begin{array}{r}0.80062 \\
0.0001\end{array}$ \\
\hline $\begin{array}{r}0.58191 \\
0.0113\end{array}$ & $\begin{array}{r}0.53333 \\
0 \quad 0227\end{array}$ & $\begin{array}{r}059556 \\
0 \quad 0091\end{array}$ & $\begin{array}{r}0.60744 \\
0.0075\end{array}$ & $\begin{array}{l}1.00000 \\
00\end{array}$ & $\begin{array}{r}0.57305 \\
0 \quad 0129\end{array}$ & $\begin{array}{r}0 \quad 61538 \\
0 \quad 0066\end{array}$ & $\begin{array}{r}088797 \\
0 \quad 0001\end{array}$ & $\begin{array}{r}0.71798 \\
0.0008\end{array}$ \\
\hline $\begin{array}{r}0.85124 \\
0.0001\end{array}$ & $\begin{array}{r}0.22521 \\
0.3689\end{array}$ & $\begin{array}{r}0.96231 \\
0.0001\end{array}$ & $\begin{array}{r}085493 \\
0.0001\end{array}$ & $\begin{array}{r}0 \quad 57305 \\
0 \quad 0129\end{array}$ & $\begin{array}{l}100000 \\
00\end{array}$ & $\begin{array}{r}086171 \\
0 \quad 0001\end{array}$ & $\begin{array}{r}0 \quad 44066 \\
0 \quad 0672\end{array}$ & $\begin{array}{r}093030 \\
0.0001\end{array}$ \\
\hline $\begin{array}{r}074070 \\
0 \quad 0004\end{array}$ & $\begin{array}{r}0.03616 \\
0.8867\end{array}$ & $\begin{array}{r}0 \quad 91275 \\
0 \quad 0001\end{array}$ & $\begin{array}{r}099226 \\
0 \quad 0001\end{array}$ & $\begin{array}{r}0 \quad 61538 \\
0 \quad 0066\end{array}$ & $\begin{array}{r}0.86171 \\
0.0001\end{array}$ & $\begin{array}{l}100000 \\
00\end{array}$ & $\begin{array}{r}0 \quad 37874 \\
0 \quad 1212\end{array}$ & $\begin{array}{r}080330 \\
0.0001\end{array}$ \\
\hline $\begin{array}{r}052996 \\
0.0237\end{array}$ & $\begin{array}{r}0.80475 \\
0.0001\end{array}$ & $\begin{array}{r}0 \quad 37997 \\
0 \quad 1199\end{array}$ & $\begin{array}{r}0 \quad 35829 \\
0 \quad 1443\end{array}$ & $\begin{array}{r}088797 \\
0 \quad 0001\end{array}$ & $\begin{array}{r}044066 \\
0.0672\end{array}$ & $\begin{array}{r}0 \quad 37874 \\
0 \quad 1212\end{array}$ & $\begin{array}{l}100000 \\
00\end{array}$ & $\begin{array}{r}0.63191 \\
0 \quad 0049\end{array}$ \\
\hline $\begin{array}{r}089664 \\
0 \quad 0001\end{array}$ & $\begin{array}{r}0 \quad 40052 \\
0 \quad 0995\end{array}$ & $\begin{array}{r}087862 \\
0 \quad 0001\end{array}$ & $\begin{array}{r}080062 \\
0 \quad 0001\end{array}$ & $\begin{array}{r}0 \quad 71798 \\
0 \quad 0008\end{array}$ & $\begin{array}{r}093030 \\
0 \quad 0001\end{array}$ & $\begin{array}{r}080330 \\
0 \quad 0001\end{array}$ & $\begin{array}{r}0 \quad 63191 \\
0 \quad 0049\end{array}$ & $\begin{array}{c}100000 \\
0.0\end{array}$ \\
\hline
\end{tabular}




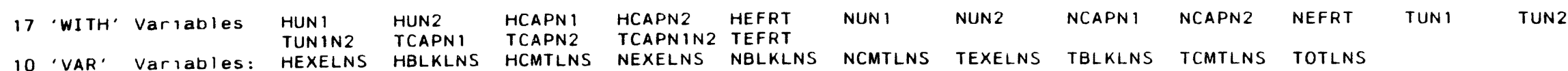

10 'VAR' Variables: HEXELNS HBLKLNS HCMTLNS NEXELNS NBLKLNS NCMTLNS TEXELNS TBLKLNS TCMTLNS TOTLNS

Simple Statistics

Variable
HUN1
HUN2
HCAPN1
HCAPN2
HEFRT
NUN1
NUN2
NCAPN1
NCAPN2
NEFRT
TUN1
TUN2
TUNIN2
TCAPN1
TCAPN2
TCAPN1N2
TEFRT
HEXELNS
HBLKLNS
HCMTLNS
NEXELNS
NBLKLNS
NCMTLNS
TEXELNS
TBLKLNS
TCMTLNS
TOTLNS

$N$
18
18
18
18
18
18
18
18
18
18
18
18
18
18
18
18
18
18
18
18
18
18
18
18
18
18
18

Mean

37555556 55.888889 $338 \quad 944444$

188777778 302424 44.500000
72.388889 72.388889
942.222222 942.222222
591.833333 2813805 82.055556 $128 \quad 277778$ 210.333333 1281166667 780611111 5209993

118.444444

34.777778 277.944444 277.944444 75.500000
246.722222 246.722222 393.00000 108.555556 83911111 2061.777778
Std Dev

11642833
$25 \quad 840891$
225123880
$122 \quad 758757$
362591
12.701320
40.744742
710.268844
465025521
3679114
22.367182
61.622003
83.223300
808.642017
511298478
317.423937
5339407
73.807558
19.028015
69.959862
204.744453
59.602852
170.113044
239.235301
73.533684
212.931975
446.659087

Median

35000000

54500000

249000000

143.500000

129673

46.000000

69500000

687.000000

412.000000
1054636

3.000000

127.000000

211.500000

1193.500000

720.500000

1889000000

3614345
7.500000

36.000000

62.500000

206.000000

49.000000

49.0000

283500000

361.500000

90.000000

1003.000000
Minimum

23000000 19000000 69000000 36.000000
12337 27.000000 26000000 151.000000

80000000 56230 50.000000 56.000000 106000000 274.000000 142.000000

416.000000 180012 29.000000
8.000000 20.000000 58.000000 58.000000
12.000000 12000000 64.000000 99.000000 25.000000 231.000000

\section{Max I imum}

61000000 113000000 827.000000 446000000 1140590
3.000000 73.000000
190000000 190000000
2565.000000 1608000000 13686523 134000000 303000000 437.000000 2824.000000 1764.000000 4588000000 18474019 253000000 84.000000 795.00000 228.000000 228.000000 68.000000 884.00000 321.000000 1427.000000 
Correlation Analysis

\begin{tabular}{|c|c|c|c|c|c|c|c|c|c|c|}
\hline & HEXELNS & HBLKLNS & HCMTLNS & NEXELNS & NBLKLNS & NCMTLNS & TEXELNS & TBLKLNS & TCMTLNS & TOTLNS \\
\hline HUNI & $\begin{array}{r}094775 \\
0 \quad 0001\end{array}$ & $\begin{array}{r}080538 \\
00001\end{array}$ & $\begin{array}{r}0 \quad 67029 \\
0.0023\end{array}$ & $\begin{array}{r}0 \quad 66477 \\
0 \quad 0026\end{array}$ & $\begin{array}{r}047750 \\
0 \quad 0451\end{array}$ & $\begin{array}{r}0 \quad 69374 \\
0 \quad 0014\end{array}$ & $\begin{array}{r}075802 \\
0.0003\end{array}$ & $\begin{array}{r}0 \quad 50776 \\
0 \quad 0315\end{array}$ & $\begin{array}{r}0 \quad 73320 \\
0 \quad 0005\end{array}$ & $\begin{array}{r}0.79979 \\
0 \quad 0001\end{array}$ \\
\hline HUN2 & $\begin{array}{r}081156 \\
0 \quad 0001\end{array}$ & $\begin{array}{r}0.70558 \\
00011\end{array}$ & $\begin{array}{r}0 \quad 46074 \\
0 \quad 0543\end{array}$ & $\begin{array}{r}0 \quad 55550 \\
0 \quad 0167\end{array}$ & $\begin{array}{r}0 \quad 41507 \\
0 \quad 0867\end{array}$ & $\begin{array}{r}0 \quad 45225 \\
0 \quad 0595\end{array}$ & $\begin{array}{r}0 \quad 63055 \\
0 \quad 0050\end{array}$ & $\begin{array}{r}0 \quad 45098 \\
0 \quad 060 \mathrm{~s}\end{array}$ & $\begin{array}{r}0 \quad 44272 \\
0 \quad 0658\end{array}$ & $\begin{array}{r}055343 \\
0.0172\end{array}$ \\
\hline HCAPNI & $\begin{array}{r}093340 \\
00001\end{array}$ & $\begin{array}{r}0.82128 \\
00001\end{array}$ & $\begin{array}{r}0 \quad 59711 \\
0 \quad 0089\end{array}$ & $\begin{array}{r}063913 \\
00045\end{array}$ & $\begin{array}{r}047909 \\
0 \quad 0443\end{array}$ & $\begin{array}{r}058028 \\
0 \quad 0116\end{array}$ & $\begin{array}{r}072343 \\
00007\end{array}$ & $\begin{array}{r}0 \quad 51496 \\
0 \quad 0287\end{array}$ & 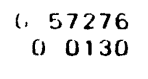 & $\begin{array}{r}070005 \\
0.0012\end{array}$ \\
\hline HCAPN2 & $\begin{array}{r}093960 \\
0.0001\end{array}$ & $\begin{array}{r}085021 \\
0.0001\end{array}$ & $\begin{array}{r}0.60227 \\
0.0082\end{array}$ & $\begin{array}{r}0 \quad 63500 \\
0.0046\end{array}$ & $\begin{array}{r}047703 \\
0 \quad 0453\end{array}$ & $\begin{array}{r}057202 \\
0 \quad 0131\end{array}$ & $\begin{array}{r}072755 \\
0.0006\end{array}$ & $\begin{array}{r}0 \quad 51084 \\
0 \quad 0303\end{array}$ & $\begin{array}{r}0 \quad 56863 \\
0 \quad 0138\end{array}$ & $\begin{array}{r}072277 \\
0.0007\end{array}$ \\
\hline HEFRT & $\begin{array}{r}096644 \\
0.0001\end{array}$ & $\begin{array}{r}0.83471 \\
0.0001\end{array}$ & $\begin{array}{r}0.66012 \\
0.0029\end{array}$ & $\begin{array}{r}0.61642 \\
0.0064\end{array}$ & $\begin{array}{r}0.45638 \\
0.0569\end{array}$ & $\begin{array}{r}063191 \\
0 \quad 0049\end{array}$ & $\begin{array}{r}0.71311 \\
0.0009\end{array}$ & $\begin{array}{r}0 \quad 48813 \\
0 \quad 0399\end{array}$ & $\begin{array}{r}0 \quad 64499 \\
0 \quad 0038\end{array}$ & $\begin{array}{r}0.73929 \\
0.0005\end{array}$ \\
\hline NUN 1 & $\begin{array}{r}0 \quad 66339 \\
0 \quad 0027\end{array}$ & $\begin{array}{r}0.73047 \\
0.0006\end{array}$ & $\begin{array}{r}0.35954 \\
0.1428\end{array}$ & $\begin{array}{r}085471 \\
0.0001\end{array}$ & $\begin{array}{r}081489 \\
0 \quad 0001\end{array}$ & $\begin{array}{r}077766 \\
00001\end{array}$ & $\begin{array}{r}084651 \\
00001\end{array}$ & $\begin{array}{r}0 \quad 82377 \\
0 \quad 0001\end{array}$ & $\begin{array}{r}0 \quad 65530 \\
0 \quad 0032\end{array}$ & $\begin{array}{r}0.86712 \\
00001\end{array}$ \\
\hline NUN2 & $\begin{array}{r}062674 \\
0.0054\end{array}$ & $\begin{array}{r}068905 \\
0.0016\end{array}$ & $\begin{array}{r}026446 \\
0.2889\end{array}$ & $\begin{array}{r}088487 \\
0.0001\end{array}$ & $\begin{array}{r}077233 \\
0.0002\end{array}$ & $\begin{array}{r}072070 \\
0 \quad 0007\end{array}$ & $\begin{array}{r}085759 \\
00001\end{array}$ & $\begin{array}{r}078535 \\
0.0001\end{array}$ & $\begin{array}{r}0 \quad 54386 \\
0 \quad 0196\end{array}$ & $\begin{array}{r}082912 \\
0.0001\end{array}$ \\
\hline NCAPNI & $\begin{array}{r}0 \quad 63810 \\
0 \quad 0044\end{array}$ & $\begin{array}{r}0.79236 \\
0.0001\end{array}$ & $\begin{array}{r}0.10537 \\
0.6773\end{array}$ & $\begin{array}{r}096954 \\
0.0001\end{array}$ & $\begin{array}{r}089623 \\
0.0001\end{array}$ & $\begin{array}{r}060919 \\
0.0073\end{array}$ & $\begin{array}{r}095666 \\
00001\end{array}$ & $\begin{array}{r}090093 \\
0 \quad 0001\end{array}$ & $\begin{array}{r}0.40144 \\
0.0987\end{array}$ & $\begin{array}{r}089623 \\
0.0001\end{array}$ \\
\hline NCAPN2 & $\begin{array}{r}060712 \\
0.0075\end{array}$ & $\begin{array}{r}076343 \\
0.0002\end{array}$ & $\begin{array}{r}0.06302 \\
0.8038\end{array}$ & $\begin{array}{r}0.98503 \\
0.0001\end{array}$ & $\begin{array}{r}092308 \\
00001\end{array}$ & $\begin{array}{r}0.60919 \\
0.0073\end{array}$ & $\begin{array}{r}095046 \\
0.0001\end{array}$ & $\begin{array}{r}0.92570 \\
0.0001\end{array}$ & $\begin{array}{r}0 \quad 38493 \\
0 \quad 1147\end{array}$ & $\begin{array}{r}0.87558 \\
0.0001\end{array}$ \\
\hline NEFRT & $\begin{array}{r}0.59060 \\
0 \quad 0099\end{array}$ & $\begin{array}{r}075517 \\
0.0003\end{array}$ & $\begin{array}{r}0.05269 \\
0.8355\end{array}$ & $\begin{array}{r}097264 \\
00001\end{array}$ & $\begin{array}{r}093753 \\
00001\end{array}$ & $\begin{array}{r}063810 \\
0 \quad 0044\end{array}$ & $\begin{array}{r}0.92982 \\
0.0001\end{array}$ & $\begin{array}{r}093808 \\
0 \quad 0001\end{array}$ & $\begin{array}{r}0 \quad 39938 \\
0.1006\end{array}$ & $\begin{array}{r}0.87145 \\
0.0001\end{array}$ \\
\hline TUNI & $\begin{array}{r}089004 \\
0.0001\end{array}$ & $\begin{array}{r}0.81715 \\
0.0001\end{array}$ & $\begin{array}{r}062397 \\
0.0056\end{array}$ & $\begin{array}{r}075065 \\
00003\end{array}$ & $\begin{array}{r}0 \quad 60093 \\
00084\end{array}$ & $\begin{array}{r}077852 \\
0.0001\end{array}$ & $\begin{array}{r}0.82250 \\
0.0001\end{array}$ & $\begin{array}{r}0.63055 \\
0.0050\end{array}$ & $\begin{array}{r}077915 \\
0 \quad 0001\end{array}$ & $\begin{array}{r}0.85596 \\
0.0001\end{array}$ \\
\hline TUN2 & $\begin{array}{r}081053 \\
0.0001\end{array}$ & $\begin{array}{r}0.82541 \\
0.0001\end{array}$ & $\begin{array}{r}046694 \\
0.0507\end{array}$ & $\begin{array}{r}0.83015 \\
0.0001\end{array}$ & $\begin{array}{r}0.68456 \\
0.0017\end{array}$ & $\begin{array}{r}067424 \\
00022\end{array}$ & $\begin{array}{r}086791 \\
00001\end{array}$ & $\begin{array}{r}071930 \\
0 \quad 0008\end{array}$ & $\begin{array}{r}0 \quad 60784 \\
0 \quad 0075\end{array}$ & $\begin{array}{r}0.83738 \\
0.0001\end{array}$ \\
\hline TUN1N2 & $\begin{array}{r}0.84134 \\
0.0001\end{array}$ & $\begin{array}{r}080558 \\
00001\end{array}$ & $\begin{array}{r}0 \quad 51706 \\
0.0280\end{array}$ & $\begin{array}{r}080052 \\
0.0001\end{array}$ & $\begin{array}{r}0.64393 \\
0.0039\end{array}$ & $\begin{array}{r}0.69302 \\
0.0014\end{array}$ & $\begin{array}{r}084917 \\
0.0001\end{array}$ & $\begin{array}{r}067872 \\
0 \quad 0020\end{array}$ & $\begin{array}{r}0.65186 \\
0.0034\end{array}$ & $\begin{array}{r}0 \quad 81757 \\
0.0001\end{array}$ \\
\hline TCAPNI & $\begin{array}{r}066908 \\
0.0024\end{array}$ & $\begin{array}{r}0.81095 \\
0.0001\end{array}$ & $\begin{array}{r}0 \quad 18905 \\
0.4525\end{array}$ & $\begin{array}{r}095509 \\
0.0001\end{array}$ & $\begin{array}{r}084770 \\
00001\end{array}$ & $\begin{array}{r}060919 \\
0.0073\end{array}$ & $\begin{array}{r}0.95253 \\
0.0001\end{array}$ & $\begin{array}{r}0 \quad 86584 \\
0 \quad 0001\end{array}$ & $\begin{array}{r}0 \quad 43240 \\
0 \quad 0731\end{array}$ & $\begin{array}{r}0.87661 \\
0.0001\end{array}$ \\
\hline TCAPN2 & $\begin{array}{r}067321 \\
0.0022\end{array}$ & $\begin{array}{r}082025 \\
0.0001\end{array}$ & $\begin{array}{r}0 \quad 14979 \\
0.5530\end{array}$ & $\begin{array}{r}096438 \\
0.0001\end{array}$ & $\begin{array}{r}0 \quad 87558 \\
00001\end{array}$ & $\begin{array}{r}0 \quad 60093 \\
0 \quad 0084\end{array}$ & $\begin{array}{r}095872 \\
0 \quad 0001\end{array}$ & $\begin{array}{r}089061 \\
0 \quad 0001\end{array}$ & $\begin{array}{r}0 \quad 40764 \\
0 \quad 0931\end{array}$ & $\begin{array}{r}0.87971 \\
0.0001\end{array}$ \\
\hline TCAPN 1N2 & $\begin{array}{r}0 \quad 67734 \\
0 \quad 0020\end{array}$ & $\begin{array}{r}0.82231 \\
00001\end{array}$ & $\begin{array}{r}0 \quad 17459 \\
0,4884\end{array}$ & $\begin{array}{r}096231 \\
00001\end{array}$ & $\begin{array}{r}0 \quad 87248 \\
0.0001\end{array}$ & $\begin{array}{r}0 \quad 611125 \\
0 \quad 0070\end{array}$ & $\begin{array}{r}096285 \\
00001\end{array}$ & $\begin{array}{r}088854 \\
0 \quad 0001\end{array}$ & $\begin{array}{r}0 \quad 43240 \\
0 \quad 0731\end{array}$ & $\begin{array}{r}088384 \\
0 \quad 0001\end{array}$ \\
\hline TEFRT & $\begin{array}{r}068353 \\
0 \quad 0018\end{array}$ & $\begin{array}{r}082438 \\
00001\end{array}$ & $\begin{array}{r}0.18079 \\
04728\end{array}$ & $\begin{array}{r}096644 \\
0 \quad 0001\end{array}$ & $\begin{array}{r}087042 \\
0 \quad 0001\end{array}$ & $\begin{array}{r}0 \quad 61538 \\
0 \quad 0066\end{array}$ & $\begin{array}{r}0.97110 \\
0.0001\end{array}$ & $\begin{array}{r}0 \quad 88442 \\
0 \quad 0001\end{array}$ & $\begin{array}{r}0 \quad 44272 \\
0 \quad 0658\end{array}$ & $\begin{array}{r}090036 \\
0.0001\end{array}$ \\
\hline
\end{tabular}


Correlation Analysis

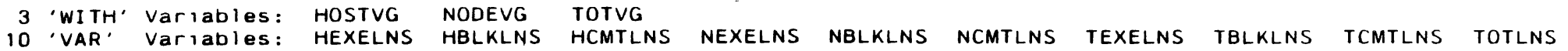

Variable
HOSTVG
NODEVG
TOTVG
HEXELNS
HBLKLNS
HCMTLNS
NEXELNS
NBLKLNS
NCMTLNS
TEXELNS
TBLKLNS
TCMTLNS
TOTLNS

N

18

18

18

18

18

18

18

18

18 .

18

\section{Simple Statistics}

$\begin{array}{rrr}\text { Mean } & \text { Std Dev } & \text { Median } \\ 14444444 & 14455702 & 7000000 \\ 57666667 & 49413025 & 35000000 \\ 7211111 & 53198727 & 52.500000 \\ 11844444 & 73807558 & 97500000 \\ 34777778 & 19.028015 & 36000000 \\ 9483333 & 69.959862 & 62.500000 \\ 277.944444 & 204.744453 & 206.000000 \\ 75.500000 & 59.602852 & 49.000000 \\ 246.722222 & 170.113044 & 283.500000 \\ 393.000000 & 239.235301 & 361.500000 \\ 108.555556 & 73533684 & 90.000000 \\ 337.555556 & 212.931975 & 329.500000 \\ 839.111111 & 446659087 & 1003.000000\end{array}$

Max imum

2.000000

6.000000

10000000

29000000

8000000

58000000

12.000000

64.000000

64.000000

99.000000

25.000000

93.000000
231.000000
47000000 152000000 158000000 253000000 84000000 233000000 795000000 228.00000 600.000000 312.000000 312.000000 721.000000 

Correlation Analysis

\begin{tabular}{|c|c|c|c|c|c|c|c|c|c|c|}
\hline & HEXELNS & HBLKLNS & HCMTLNS & NEXELNS & NBLKLNS & NCMTLNS & TEXELNS & TBLKLNS & TCMTLNS & TOTLNS \\
\hline HOSTVG & $\begin{array}{r}0.83517 \\
0 \quad 0001\end{array}$ & $\begin{array}{r}0.65974 \\
0.0029\end{array}$ & $\begin{array}{r}0.65610 \\
0.0031\end{array}$ & $\begin{array}{r}0 \quad 46803 \\
0 \quad 0501\end{array}$ & $\begin{array}{r}0.19969 \\
0 \quad 4269\end{array}$ & $\begin{array}{r}0.46959 \\
0 \quad 0493\end{array}$ & $\begin{array}{r}057382 \\
0.0128\end{array}$ & $\begin{array}{r}02350 \\
0 \quad 3727\end{array}$ & $\begin{array}{r}0.581110 \\
0 \quad 01114\end{array}$ & $\begin{array}{r}0 \quad 64328 \\
0 \quad 0040\end{array}$ \\
\hline NODEVG & $\begin{array}{r}0 \quad 60879 \\
0 \quad 0073\end{array}$ & $\begin{array}{r}078645 \\
0 \quad 0001\end{array}$ & $\begin{array}{r}0 \quad 13289 \\
0 \quad 5991\end{array}$ & $\begin{array}{r}0 \quad 95401 \\
0 \quad 0001\end{array}$ & $\begin{array}{r}091163 \\
0 \quad 0001\end{array}$ & $\begin{array}{r}0 \quad 66925 \\
0 \quad 0024\end{array}$ & $\begin{array}{r}0 \quad 93079 \\
0 \quad 0001\end{array}$ & $\begin{array}{r}0 \quad 92046 \\
0 \quad 0001\end{array}$ & $\begin{array}{r}0 \quad 47211 \\
0 \quad 0479\end{array}$ & $\begin{array}{r}0.89457 \\
0 \quad 0001\end{array}$ \\
\hline TOTVG & $\begin{array}{r}0 \quad 68320 \\
0 \quad 0018\end{array}$ & $\begin{array}{r}0 \quad 82265 \\
0.0001\end{array}$ & $\begin{array}{r}0 \quad 22182 \\
0 \quad 3764\end{array}$ & $\begin{array}{r}0 \quad 93540 \\
0 \quad 0001\end{array}$ & $\begin{array}{r}081654 \\
0 \quad 0001\end{array}$ & $\begin{array}{r}0 \quad 61447 \\
0 \quad 0067\end{array}$ & $\begin{array}{r}0 \quad 94938 \\
0 \quad 0001\end{array}$ & $\begin{array}{r}0 \quad 83368 \\
0 \quad 0001\end{array}$ & $\begin{array}{r}046591 \\
0 \quad 0513\end{array}$ & $\begin{array}{r}0 \quad 90698 \\
0 \quad 0001\end{array}$ \\
\hline
\end{tabular}


7 'WITH' Variables: HMSGSND HMSGREC NMSGSND NMSGREC TMSGSND TMSGREC TCOMMSG

$$
\text { Correlation Analysis }
$$
ariables: HEXELNS HBLKLNS HCMTLNS NEXELNS NBLKLNS NCMTLNS
TEXELNS
TBLKLNS TCMTLNS TOTLNS

Simple Statistics

Variable
HMSGSND
HMSGREC
NMSGSND
NMSGREC
TMSGSND
TMSGREC
TCOMMSG
HEXELNS
HBLKLNS
HCMTLNS
NEXELNS
NBLKLNS
NCMTLNS
TEXELNS
TBLKLNS
TCMTLNS
TOTLNS

$N$
18
18
18
18
18
18
18
18
18
18
18
18
18
18
18
18
18

Mean

Std Dev

Median

Minımum

Max imum

$$
\begin{array}{r}
4277778 \\
2611111 \\
8 \quad 888889 \\
10555556 \\
13166667 \\
13.166667 \\
26.333333 \\
118.444444 \\
34.777778 \\
94.833333 \\
277.944444 \\
75.500000 \\
246.722222 \\
393.000000 \\
108.555556 \\
337.555556
\end{array}
$$

337.555556

2803476
1144752
6641128
6.921596
7.270003
7.196813
14.418126
73.807558
19.028015
69.959862
204.744453
59.602852
170.113044
239.235301
73.533684
212.931975
446.659087

4.500000

2.000000

9.000000
10.000000

10.000000

13.000000

27.000000

97.500000

36.000000

62.500000

206.000000

49.000000

283.500000

361.500000

90.000000

329.500000

446.659087

1003.000000

000000

5000000

32000000

33000000

35000000

35.000000

70.000000

253.000000

84.000000

233.000000

795.000000

228.000000

600.000000

884.000000

312000000
721

1427.000000 
Correlation Analysis

\begin{tabular}{|c|c|c|c|c|c|c|c|c|c|c|}
\hline & HEXELNS & MBLKLNS & HCMTLNS & NEXELNS & NBLKLNS & NCMTLNS & TEXELNS & TBLKLNS & TCMTLNS & TOTLNS \\
\hline HMSGSND & $\begin{array}{r}064148 \\
0.0041\end{array}$ & $\begin{array}{r}040524 \\
0.0952\end{array}$ & $\begin{array}{r}0.49089 \\
0.0386\end{array}$ & $\begin{array}{r}0.12005 \\
0.6352\end{array}$ & $\begin{array}{r}-0.12579 \\
0.6189\end{array}$ & $\begin{array}{r}0.06159 \\
0.8082\end{array}$ & $\begin{array}{r}0.25980 \\
0.2978\end{array}$ & $\begin{array}{r}-010851 \\
06682\end{array}$ & $\begin{array}{r}0 \quad 19302 \\
0.4429\end{array}$ & $\begin{array}{r}025158 \\
0.3139\end{array}$ \\
\hline HMSGREC & $\begin{array}{r}060723 \\
0.0075\end{array}$ & $\begin{array}{r}0.49260 \\
0.0378\end{array}$ & $\begin{array}{r}0.47618 \\
0.0458\end{array}$ & $\begin{array}{r}0 \quad 63020 \\
0 \quad 0051\end{array}$ & $\begin{array}{r}057386 \\
0.0128\end{array}$ & $\begin{array}{r}0.62145 \\
0.0059\end{array}$ & $\begin{array}{r}0.60254 \\
0 \quad 0081\end{array}$ & $\begin{array}{r}0.62003 \\
0.0061\end{array}$ & $\begin{array}{r}058504 \\
0.0108\end{array}$ & $\begin{array}{r}0.50766 \\
0.0315\end{array}$ \\
\hline NMSGSNO & $\begin{array}{r}0.28201 \\
0 \quad 2569\end{array}$ & $\begin{array}{r}0.45498 \\
0 \quad 0578\end{array}$ & $\begin{array}{r}0.04633 \\
0.8551\end{array}$ & $\begin{array}{r}067119 \\
0 \quad 0023\end{array}$ & $\begin{array}{r}058170 \\
0.0113\end{array}$ & $\begin{array}{r}0.28565 \\
0.2505\end{array}$ & $\begin{array}{r}0.61156 \\
0 \quad 0070\end{array}$ & $\begin{array}{r}0 \\
011156 \\
0 \quad 0070\end{array}$ & $\begin{array}{r}0 \quad 13625 \\
0 \quad 5898\end{array}$ & $\begin{array}{r}0.44330 \\
0.0654\end{array}$ \\
\hline NMSGREC & $\begin{array}{r}061037 \\
0.0071\end{array}$ & $\begin{array}{r}063655 \\
0.0045\end{array}$ & $\begin{array}{r}0.22116 \\
0.3778\end{array}$ & $\begin{array}{r}0.53493 \\
0.0222\end{array}$ & $\begin{array}{r}0.32708 \\
0.1852\end{array}$ & $\begin{array}{r}0.05961 \\
0.8142\end{array}$ & $\begin{array}{r}0.62007 \\
0.0060\end{array}$ & $\begin{array}{r}0 \quad 34800 \\
0.1570\end{array}$ & $\begin{array}{r}0 \\
04429 \\
0 \quad 8615\end{array}$ & $\begin{array}{r}046213 \\
0.0535\end{array}$ \\
\hline TMSGSND & $\begin{array}{r}0.58516 \\
0.0107\end{array}$ & $\begin{array}{r}0.65092 \\
0 \quad 0034\end{array}$ & $\begin{array}{r}0.29974 \\
0.2269\end{array}$ & $\begin{array}{r}0.62825 \\
0 \quad 0052\end{array}$ & $\begin{array}{r}0.43355 \\
0.0723\end{array}$ & $\begin{array}{r}0.24611 \\
0.3249\end{array}$ & $\begin{array}{r}066218 \\
0.0028\end{array}$ & $\begin{array}{r}0.45045 \\
0.0607\end{array}$ & $\begin{array}{r}0.20447 \\
04157\end{array}$ & $\begin{array}{r}0.55452 \\
0.0169\end{array}$ \\
\hline TMSGREC & $\begin{array}{r}0.64234 \\
0.0040\end{array}$ & $\begin{array}{r}0.69649 \\
0.0013\end{array}$ & $\begin{array}{r}0.22363 \\
0.3724\end{array}$ & $\begin{array}{r}0.72903 \\
0.0006\end{array}$ & $\begin{array}{r}055042 \\
0.0179\end{array}$ & $\begin{array}{r}0.23239 \\
0.3534\end{array}$ & $\begin{array}{r}0.78084 \\
0.0001\end{array}$ & $\begin{array}{r}0.57937 \\
0.0117\end{array}$ & $\begin{array}{r}0.17851 \\
0 \quad 4785\end{array}$ & $\begin{array}{r}0.59534 \\
0.0091\end{array}$ \\
\hline TCOMMSG & $\begin{array}{r}0.62773 \\
0.0053\end{array}$ & $\begin{array}{r}0.69403 \\
0.0014\end{array}$ & $\begin{array}{r}0.28676 \\
0.2486\end{array}$ & $\begin{array}{r}0.66564 \\
0.0026\end{array}$ & $\begin{array}{r}0.49378 \\
0.0373\end{array}$ & $\begin{array}{r}0.24922 \\
0.3186\end{array}$ & $\begin{array}{r}0.71407 \\
0.0009\end{array}$ & $\begin{array}{r}0.52103 \\
0.0266\end{array}$ & $\begin{array}{r}021277 \\
0.3966\end{array}$ & $\begin{array}{r}0.56854 \\
0.0138\end{array}$ \\
\hline
\end{tabular}


Correlation Analysis

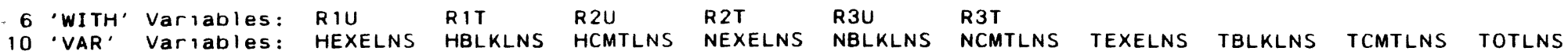

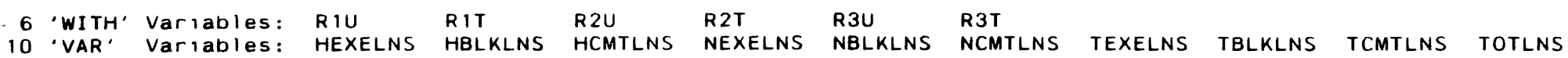

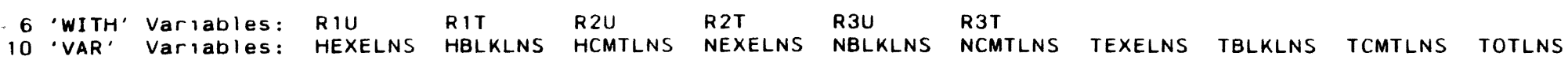

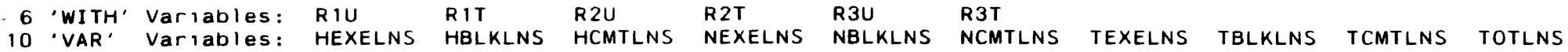

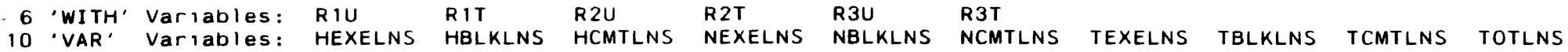

Simple Statistics

Variable
RIU
RIT
R2U
R2T
R3U
R3T
HEXELNS
HBLKLNS
HCMTLNS
NEXELNS
NBLKLNS
NCMTLNS
TEXELNS
TBLKLNS
TCMTLNS

N

Mean

1342.900000
21311

1439.194444

1238.461111

19770

118.444444

34.777778

94.833333

277.944444

75.500000

246.722222

393.000000

108.555556

337.555556

839.111111
Std Dev

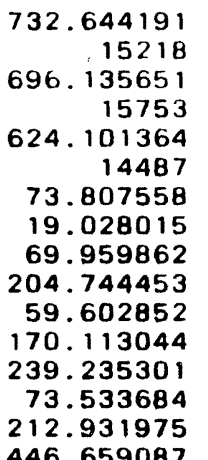

Median

1326.050000 18777

1424.650000

19021
250000

1223.250000

17229
.500000

36.000000

62.500000

206.000000

49000000

283.500000

361.500000

90.000000

329.500000
Minimum

296700000 3234100000 610.400000

3207000000

505.800000

2821.800000

29.000000

8. 000000

20000000

58.000000

12000000

64.000000

99.000000

25.000000

93.000000

231.000000
Maximum

3444.500000 51397 3409.300000 3022.500000 49388
253.000000 84.000000 233.000000 795.000000 228.000000 600.000000 884.000000 312.000000 721.000000 1427.000000 
Correlation Analysis

Spearman Correlation Coefficients / Prob > $|R|$ under Ho: Rho=0/N=18

\begin{tabular}{|c|c|c|c|c|c|c|c|c|c|c|}
\hline & HEXELNS & HBLKLNS & HCMTLNS & NEXELNS & NBLKLNS & NCMTLNS & TEXELNS & TBLKLNS & TCMTLNS & TOTLNS \\
\hline RIU & $\begin{array}{r}0.71864 \\
0.0008\end{array}$ & $\begin{array}{r}0.61984 \\
0 \quad 0061\end{array}$ & $\begin{array}{r}0.37190 \\
0.1286\end{array}$ & $\begin{array}{r}0.70005 \\
0.0012\end{array}$ & $\begin{array}{r}0.52142 \\
0.0265\end{array}$ & $\begin{array}{r}0.42230 \\
0 \quad 0808\end{array}$ & $\begin{array}{r}0.74200 \\
0 \quad 0004\end{array}$ & $\begin{array}{r}0.52322 \\
0 \quad 0259\end{array}$ & $\begin{array}{r}0.41176 \\
0 \quad 0895\end{array}$ & $\begin{array}{r}0.64533 \\
0.0038\end{array}$ \\
\hline$R I T$ & $\begin{array}{r}0.67734 \\
0 \quad 0020\end{array}$ & $\begin{array}{r}082231 \\
0.0001\end{array}$ & $\begin{array}{r}0.17459 \\
0.4884\end{array}$ & $\begin{array}{r}0.96231 \\
0.0001\end{array}$ & $\begin{array}{r}0.87248 \\
00001\end{array}$ & $\begin{array}{r}0.611125 \\
0 \quad 0070\end{array}$ & $\begin{array}{r}0.96285 \\
0.0001\end{array}$ & $\begin{array}{r}088854 \\
0 \quad 0001\end{array}$ & $\begin{array}{r}0.43240 \\
0 \quad 0731\end{array}$ & $\begin{array}{r}0.88384 \\
0.0001\end{array}$ \\
\hline$R 2 U$ & $\begin{array}{r}084151 \\
0 \quad 0001\end{array}$ & $\begin{array}{r}0.81302 \\
0 \quad 0001\end{array}$ & $\begin{array}{r}0.50000 \\
0 \quad 0346\end{array}$ & $\begin{array}{r}0.81053 \\
0.0001\end{array}$ & $\begin{array}{r}0.64739 \\
0.0037\end{array}$ & $\begin{array}{r}0.68147 \\
0.0018\end{array}$ & $\begin{array}{r}0.86171 \\
0.0001\end{array}$ & $\begin{array}{r}0 \quad 68215 \\
0 \quad 0018\end{array}$ & $\begin{array}{r}0 \quad 63674 \\
0 \quad 0045\end{array}$ & $\begin{array}{r}0.82499 \\
0.0001\end{array}$ \\
\hline R2T & $\begin{array}{r}0.67734 \\
0.0020\end{array}$ & $\begin{array}{r}082231 \\
0.0001\end{array}$ & $\begin{array}{r}0.17459 \\
0.4884\end{array}$ & $\begin{array}{r}0 \quad 96231 \\
0 \quad 0001\end{array}$ & $\begin{array}{r}0.87248 \\
00001\end{array}$ & $\begin{array}{r}0.61125 \\
0.0070\end{array}$ & $\begin{array}{r}0.96285 \\
0.0001\end{array}$ & $\begin{array}{r}0.88854 \\
0.0001\end{array}$ & $\begin{array}{r}0 \quad 43240 \\
0.0731\end{array}$ & $\begin{array}{r}0.88384 \\
0.0001\end{array}$ \\
\hline R3U & $\begin{array}{r}0.83781 \\
0.0001\end{array}$ & $\begin{array}{r}081137 \\
0.0001\end{array}$ & $\begin{array}{r}0.50646 \\
0.0320\end{array}$ & $\begin{array}{r}080733 \\
0.0001\end{array}$ & $\begin{array}{r}0.64669 \\
0.0037\end{array}$ & $\begin{array}{r}0.68027 \\
0 \quad 0019\end{array}$ & $\begin{array}{r}085803 \\
0.0001\end{array}$ & $\begin{array}{r}0.68147 \\
0 \quad 0018\end{array}$ & $\begin{array}{r}0 \quad 63913 \\
0 \quad 0043\end{array}$ & $\begin{array}{r}0.82335 \\
0.0001\end{array}$ \\
\hline R3T & $\begin{array}{r}0.67734 \\
0.0020\end{array}$ & $\begin{array}{r}082231 \\
0.0001\end{array}$ & $\begin{array}{r}0.17459 \\
0 \quad 4884\end{array}$ & $\begin{array}{r}0.96231 \\
0.0001\end{array}$ & $\begin{array}{r}087248 \\
0.0001\end{array}$ & $\begin{array}{r}0 \quad 61125 \\
0.0070\end{array}$ & $\begin{array}{r}0 \quad 96285 \\
0 \quad 0001\end{array}$ & $\begin{array}{r}0.88854 \\
00001\end{array}$ & $\begin{array}{r}0 \quad 43240 \\
0 \quad 0731\end{array}$ & $\begin{array}{r}0.88384 \\
0.0001\end{array}$ \\
\hline
\end{tabular}




$\begin{array}{ll}17 \text { 'WITH' } & \text { Variables } \\ 17 \text { 'VAR' } & \text { Variables } \\ & \\ & \\ & \\ & \text { Variable } \\ & \text { HUN1 } \\ \text { HUN2 } \\ \text { HCAPN1 } \\ \text { HCAPN2 } \\ \text { HEFRT } \\ \text { NUN1 } \\ \text { NUN2 } \\ \text { NCAPN1 } \\ \text { NCAPN2 } \\ \text { NEFRT } \\ \text { TUN1 } \\ \text { TUN2 } \\ \text { TUN1N2 } \\ \text { TCAPN1 } \\ \text { TCAPN2 } \\ \text { TCAPN1N2 } \\ \text { TEFRT }\end{array}$

$\begin{array}{ll}\text { HUN1 } & \text { HUN2 } \\ \text { TUN1N2 } & \text { TCAPN1 } \\ \text { HUN1 } & \text { HUN2 } \\ \text { TUN1N2 } & \text { TCAPN1 }\end{array}$

HCAPN 1
TCAPN2
HCAPN 1
TCAPN2

Correlation Analysis

$\begin{array}{llr}\text { HCAPN2 } & \text { HEFRT } \\ \text { TCAPN1N2 } & \text { TEFRT } \\ \text { HCAPN2 } & \text { HEFRT } 1 \\ \text { TCAPNIN2 } & \text { TEFRT NUN1 } \\ & \\ \text { Simple Statistics }\end{array}$

Mean

$$
\text { Std Dev }
$$

Me'dian

37.555556
55.888889
338.944444
188.777778
302424
44.500000
72.388889
942.222222
591.83333
2813805
82.055556
128.277778
210.33333
281.166667
780.611111
2061.777778
5209993

11642833

25.840891

225.123880

122.758757

362591
12.701320

40.744742

710.268844

465.025521

3679114

22.367182

61.622003

83.223300

808.642017

511.298478

1317.423937

NUN2
NUN2

NCAPN 1

NCAPN2

TUN 1

TUN2

NCAPN 1

NCAPN2 NEFRT

TUN 1

TUN2
35.000000
54.500000
249.000000
143.500000
129673
46.000000
69.500000
687.000000
12.000000
1054636
127.000000
211.500000
1193.500000
720.500000
1889.000000
3614345

Minimum

23000000

19.000000

69.000000

36.000000

27.000000

26.000000

151.000000

80.000000

56230

50.000000

56.000000

106.000000

274.000000

142.000000

416.000000

180012
Max Imum

61000000 113.000000 846.00000 $\begin{array}{r}1140590 \\ \hline\end{array}$ 73.000000 190.000000 2565.000000 1608.000000 13686523
34.000000 303.000000 437.000000 2824.000000 1764.000000 4588. 000000

18474019 
Correlation Analysis

Spearman Correlation Coefficients / Prob > $|R|$ under Ho. Rho=0/ $N=18$

\begin{tabular}{|c|c|c|c|c|c|c|c|c|c|}
\hline & HUNI & HUN2 & HCAPN 1 & HCAPN2 & HEFRT & NUNI & NUN2 & NCAPN I & NCAPN2 \\
\hline HUNI & $\begin{array}{l}100000 \\
0.0\end{array}$ & $\begin{array}{r}081903 \\
0 \quad 0001\end{array}$ & $\begin{array}{r}0.92451 \\
00001\end{array}$ & $\begin{array}{r}0.92451 \\
00001\end{array}$ & $\begin{array}{r}095450 \\
00001\end{array}$ & $\begin{array}{r}073433 \\
0.0005\end{array}$ & $\begin{array}{r}0.74561 \\
0 \quad 0004\end{array}$ & $\begin{array}{r}069183 \\
0 \quad 0015\end{array}$ & $\begin{array}{r}0.65357 \\
0.0033\end{array}$ \\
\hline HUN2 & $\begin{array}{r}0 \quad 81903 \\
0 \quad 0001\end{array}$ & $\begin{array}{l}100000 \\
0.0\end{array}$ & $\begin{array}{r}092776 \\
0 \quad 0001\end{array}$ & $\begin{array}{r}090712 \\
0 \quad 0001\end{array}$ & $\begin{array}{r}087616 \\
00001\end{array}$ & $\begin{array}{r}05091 \\
0 \quad 0178\end{array}$ & $\begin{array}{r}0 \quad 61404 \\
0 \quad 0067\end{array}$ & $\begin{array}{r}0 \quad 59959 \\
0 \quad 0085\end{array}$ & $\begin{array}{r}056656 \\
0 \quad 0142\end{array}$ \\
\hline HCAPN 1 & $\begin{array}{r}092451 \\
00001\end{array}$ & $\begin{array}{r}092776 \\
0 \quad 0001\end{array}$ & $\begin{array}{l}100000 \\
00\end{array}$ & $\begin{array}{r}099587 \\
0 \quad 0001\end{array}$ & $\begin{array}{r}098555 \\
0 \quad 0001\end{array}$ & $\begin{array}{r}065840 \\
0 \quad 0030\end{array}$ & $\begin{array}{r}0 \quad 66770 \\
0 \quad 0025\end{array}$ & $\begin{array}{r}0 \quad 65738 \\
0 \quad 0030\end{array}$ & $\begin{array}{r}062642 \\
0 \quad 0054\end{array}$ \\
\hline HCAPN2 & $\begin{array}{r}092451 \\
00001\end{array}$ & $\begin{array}{r}0.90712 \\
0.0001\end{array}$ & $\begin{array}{r}099587 \\
0.0001\end{array}$ & $\begin{array}{l}100000 \\
00\end{array}$ & $\begin{array}{r}098968 \\
00001\end{array}$ & $\begin{array}{r}0 \quad 65013 \\
0 \quad 0035\end{array}$ & $\begin{array}{r}0.65325 \\
0.0033\end{array}$ & $\begin{array}{r}065531 \\
0 \quad 0032\end{array}$ & $\begin{array}{r}062023 \\
0.0060\end{array}$ \\
\hline HEFRT & $\begin{array}{r}0.95450 \\
00001\end{array}$ & $\begin{array}{r}0.87616 \\
0.0001\end{array}$ & $\begin{array}{r}0.98555 \\
0.0001\end{array}$ & $\begin{array}{r}098968 \\
00001\end{array}$ & $\begin{array}{l}100000 \\
00\end{array}$ & $\begin{array}{r}066563 \\
0 \quad 0026\end{array}$ & $\begin{array}{r}0 \quad 65531 \\
0 \quad 0032\end{array}$ & $\begin{array}{r}0 \quad 63674 \\
0 \quad 0045\end{array}$ & $\begin{array}{r}0 \quad 60165 \\
0 \quad 0083\end{array}$ \\
\hline NUNI & $\begin{array}{r}0 \quad 73433 \\
0-0005\end{array}$ & $\begin{array}{r}0.55091 \\
0 \quad 0178\end{array}$ & $\begin{array}{r}065840 \\
0 \quad 0030\end{array}$ & $\begin{array}{r}065013 \\
0.0035\end{array}$ & $\begin{array}{r}066563 \\
0 \quad 0026\end{array}$ & $\begin{array}{l}100000 \\
00\end{array}$ & $\begin{array}{r}092300 \\
0 \quad 0001\end{array}$ & $\begin{array}{r}0 \quad 90026 \\
0.0001\end{array}$ & $\begin{array}{r}0.89199 \\
0 \quad 0001\end{array}$ \\
\hline NUN2 & $\begin{array}{r}074561 \\
0 \quad 0004\end{array}$ & $\begin{array}{r}061404 \\
0.0067\end{array}$ & $\begin{array}{r}0.66770 \\
0.0025\end{array}$ & $\begin{array}{r}0.65325 \\
0.0033\end{array}$ & $\begin{array}{r}065531 \\
0 \quad 0032\end{array}$ & $\begin{array}{r}092300 \\
0 \quad 0001\end{array}$ & $\begin{array}{l}100000 \\
0.0\end{array}$ & $\begin{array}{r}092363 \\
0 \quad 0001\end{array}$ & $\begin{array}{r}090712 \\
0 \quad 0001\end{array}$ \\
\hline NCAPN 1 & $\begin{array}{r}069183 \\
0 \quad 0015\end{array}$ & $\begin{array}{r}059959 \\
0 \quad 0085\end{array}$ & $\begin{array}{r}0.65738 \\
0.0030\end{array}$ & $\begin{array}{r}065531 \\
0.0032\end{array}$ & $\begin{array}{r}0.63674 \\
0.0045\end{array}$ & $\begin{array}{r}0.90026 \\
00001\end{array}$ & $\begin{array}{r}0.92363 \\
0.0001\end{array}$ & $\begin{array}{l}100000 \\
00\end{array}$ & $\begin{array}{r}099174 \\
0.0001\end{array}$ \\
\hline NCAPN2 & $\begin{array}{r}0 \quad 65357 \\
0 \quad 0033\end{array}$ & $\begin{array}{r}0.56656 \\
0.0142\end{array}$ & $\begin{array}{r}0.62642 \\
0.0054\end{array}$ & $\begin{array}{r}0.62023 \\
0.0060\end{array}$ & $\begin{array}{r}060165 \\
0 \quad 0083\end{array}$ & $\begin{array}{r}089199 \\
0.0001\end{array}$ & $\begin{array}{r}0.90712 \\
0 \quad 0001\end{array}$ & $\begin{array}{r}0.99174 \\
0.0001\end{array}$ & $\begin{array}{l}100000 \\
00\end{array}$ \\
\hline NEFRT & $\begin{array}{r}0.62978 \\
0.0051\end{array}$ & $\begin{array}{r}0.52735 \\
0.0245\end{array}$ & $\begin{array}{r}0.60372 \\
0.0080\end{array}$ & $\begin{array}{r}059959 \\
0.0085\end{array}$ & $\begin{array}{r}058308 \\
0.0111\end{array}$ & $\begin{array}{r}0.90749 \\
0.0001\end{array}$ & $\begin{array}{r}0.89680 \\
0.0001\end{array}$ & $\begin{array}{r}098555 \\
0.0001\end{array}$ & $\begin{array}{r}0.99381 \\
0.0001\end{array}$ \\
\hline TUNI & $\begin{array}{r}0.95864 \\
0.0001\end{array}$ & $\begin{array}{r}0.79154 \\
0.0001\end{array}$ & $\begin{array}{r}087822 \\
0 \quad 0001\end{array}$ & $\begin{array}{r}0.87203 \\
0.0001\end{array}$ & $\begin{array}{r}0.89886 \\
0.0001\end{array}$ & $\begin{array}{r}0.85685 \\
0.0001\end{array}$ & $\begin{array}{r}0.85552 \\
0.0001\end{array}$ & $\begin{array}{r}0.78535 \\
0.0001\end{array}$ & $\begin{array}{r}0.75851 \\
0.0003\end{array}$ \\
\hline TUN2 & $\begin{array}{r}088728 \\
0 \quad 0001\end{array}$ & $\begin{array}{r}0.84520 \\
0.0001\end{array}$ & $\begin{array}{r}086791 \\
00001\end{array}$ & $\begin{array}{r}0.85346 \\
0.0001\end{array}$ & $\begin{array}{r}084727 \\
0.0001\end{array}$ & $\begin{array}{r}085788 \\
0.0001\end{array}$ & $\begin{array}{r}0 \quad 90918 \\
0 \quad 0001\end{array}$ & $\begin{array}{r}086997 \\
0 \quad 0001\end{array}$ & $\begin{array}{r}0.84727 \\
0.0001\end{array}$ \\
\hline TUNIN2 & $\begin{array}{r}091667 \\
0.0001\end{array}$ & $\begin{array}{r}086364 \\
0.0001\end{array}$ & $\begin{array}{r}0.88946 \\
0.0001\end{array}$ & $\begin{array}{r}0.87190 \\
0 \quad 0001\end{array}$ & $\begin{array}{r}087293 \\
00001\end{array}$ & $\begin{array}{r}084635 \\
0.0001\end{array}$ & $\begin{array}{r}0.88946 \\
00001\end{array}$ & $\begin{array}{r}083471 \\
00001\end{array}$ & $\begin{array}{r}0.81302 \\
0.0001\end{array}$ \\
\hline TCAPN I & $\begin{array}{r}0.73733 \\
0 \quad 0005\end{array}$ & $\begin{array}{r}0.66357 \\
0.0027\end{array}$ & $\begin{array}{r}072755 \\
0 \quad 0006\end{array}$ & $\begin{array}{r}072136 \\
0 \quad 0007\end{array}$ & $\begin{array}{r}0.69453 \\
0.0014\end{array}$ & $\begin{array}{r}090749 \\
0.0001\end{array}$ & $\begin{array}{r}0 \quad 93189 \\
0 \quad 0001\end{array}$ & $\begin{array}{r}098142 \\
0 \quad 0001\end{array}$ & $\begin{array}{r}0.97317 \\
0 \quad 0001\end{array}$ \\
\hline TCAPN2 & $\begin{array}{r}071872 \\
0 \quad 0008\end{array}$ & $\begin{array}{r}0.66770 \\
0.0025\end{array}$ & $\begin{array}{r}072136 \\
0 \quad 0007\end{array}$ & $\begin{array}{r}071517 \\
0 \quad 0008\end{array}$ & $\begin{array}{r}068834 \\
0 \quad 0016\end{array}$ & $\begin{array}{r}089923 \\
0 \quad 0001\end{array}$ & $\begin{array}{r}0 \quad 91744 \\
0 \quad 0001\end{array}$ & $\begin{array}{r}098762 \\
0 \quad 0001\end{array}$ & $\begin{array}{r}0.98349 \\
0.0001\end{array}$ \\
\hline TCAPN IN2 & $\begin{array}{r}072596 \\
0 \quad 0006\end{array}$ & $\begin{array}{r}0.66563 \\
00026\end{array}$ & $\begin{array}{r}0 \quad 72343 \\
0 \quad 0007\end{array}$ & $\begin{array}{r}071723 \\
0.0008\end{array}$ & $\begin{array}{r}069040 \\
0.0015\end{array}$ & $\begin{array}{r}090646 \\
0 \quad 0001\end{array}$ & $\begin{array}{r}091950 \\
0 \quad 0001\end{array}$ & $\begin{array}{r}0.98349 \\
0 \quad 0001\end{array}$ & $\begin{array}{r}097936 \\
0.0001\end{array}$ \\
\hline TEFRT & $\begin{array}{r}0 \quad 73320 \\
0 \quad 0005\end{array}$ & $\begin{array}{r}064293 \\
0 \quad 0040\end{array}$ & $\begin{array}{r}071311 \\
0 \quad 0009\end{array}$ & $\begin{array}{r}070898 \\
0.0010\end{array}$ & $\begin{array}{r}068834 \\
0 \quad 0016\end{array}$ & $\begin{array}{r}091163 \\
0.0001\end{array}$ & $\begin{array}{r}091744 \\
0 \quad 0001\end{array}$ & $\begin{array}{r}098555 \\
0 \quad 0001\end{array}$ & $\begin{array}{r}098142 \\
0.0001\end{array}$ \\
\hline
\end{tabular}


Correlation Analysis

Spearman Correlation Coefficients / Prob > $|R|$ under Ho: Rho=0 / $N=18$

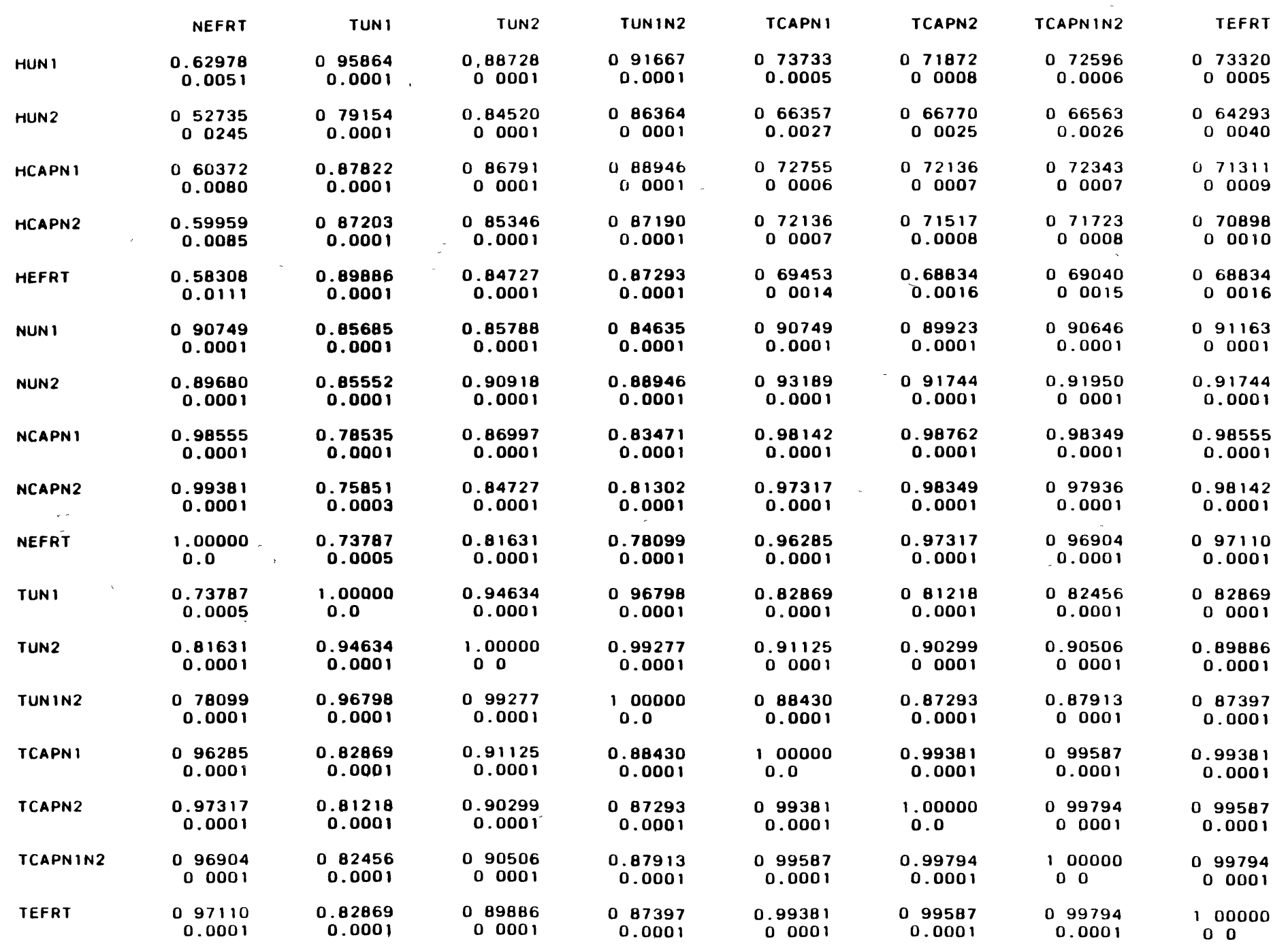




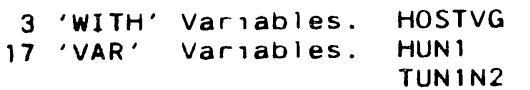

NODEVG HUN2 TCAPN 1

Correlation Analysis

TOTVG

HCAPN 1
TCAPN 2
HCAPN2

TCAPNIN2 HEFR
NUN 1

NUN2

NCAPN 1

NCAPN2 NEFRT
TUN 1

TUN2

Variable
HOSTVG
NODEVG
TOTVG
HUN1
HUN2
HCAPN1
HCAPN2
HEFRT
NUN1
NUN2
NCAPN1
NCAPN2
NEFRT
TUN1
TUN2
TUN1N2
TCAPN1
TCAPN2
TCAPN1N2
TEFRT

\section{Simple Statistics}

$N$
18
18
18
18
18
18
18
18
18
18
18
18
18
18
18
18
18
18
18
18

\section{Std Dev}

57666667

$\begin{array}{ll}52 & 111111\end{array}$

37.555556

55.888889

338.944444

$188 \quad 777778$

302424

44.500000

92.388889

591.833333

2813805

82.055556

128.277778

210.333333

1281.166667

780.611111

2061.777778

5209993
$49 \quad 413025$

$\begin{array}{ll}53 & 198727\end{array}$

11.642833

25.840891

225.123880

122.758757

362591

12.701320

40.744742

710.268844

465.025521

3679114

22.367182

61.622003

83. 223300

808.642017

511.298478

317.423937

5339407

Median
7000000
35000000
52500000
35000000
54500000
249.000000
143.500000
129673
46000000
69.500000
687.000000
412.000000
1054636
83.000000
127.000000
211.500000
1193.500000
720.500000
1889.000000
3614345

Minimum

2000000

6000000

10000000

23000000

19000000

69000000

$\begin{array}{ll}36 & 000000\end{array}$

27000000

26.000000

151000000

80.000000

.000000

50.000000

56.000000

56.000000
106.000000

274.000000

142.000000

416.000000

180012
Max I mum

47000000

152000000

$\begin{array}{rr}158 & 000000 \\ 61 & 000000\end{array}$

113.000000

827.000000

446. 000000

1140590

190000000

2565.000000

1608.000000

13686523

134.000000

303000000

2824.000000

2824.000000

1764.000000

$\begin{array}{r}18474019 \\ \hline\end{array}$ 


\section{Correlation Analysis}

\begin{tabular}{|c|c|c|c|c|c|c|c|c|c|}
\hline & HUNI & HUN2 & HCAPN 1 & HCAPN 2 & HEFRT & NUN 1 & NUN2 & NCAPN 1 & NCAPN2 \\
\hline HOSTVG & $\begin{array}{r}0.92085 \\
0.0001\end{array}$ & $\begin{array}{r}0.71831 \\
0.0008\end{array}$ & $\begin{array}{r}082123 \\
0.0001\end{array}$ & $\begin{array}{r}083162 \\
0.0001\end{array}$ & $\begin{array}{r}086489 \\
0 \quad 0001\end{array}$ & $\begin{array}{r}051901 \\
0.0273\end{array}$ & $\begin{array}{r}055823 \\
0 \quad 0161\end{array}$ & $\begin{array}{r}0 \quad 49689 \\
0 \quad 0359\end{array}$ & $\begin{array}{r}0.44596 \\
0.0636\end{array}$ \\
\hline NODEVG & $\begin{array}{r}0.66304 \\
0 \quad 0027\end{array}$ & $\begin{array}{r}052169 \\
0 \quad 0264\end{array}$ & $\begin{array}{r}0 \quad 60641 \\
0 \quad 0076\end{array}$ & $\begin{array}{r}0 \quad 60641 \\
0 \quad 0076\end{array}$ & $\begin{array}{r}0 \quad 59814 \\
0.0087\end{array}$ & $\begin{array}{r}091930 \\
0.0001\end{array}$ & $\begin{array}{r}0 \quad 90703 \\
0 \quad 0001\end{array}$ & $\begin{array}{r}0 \quad 96694 \\
0 \quad 0001\end{array}$ & $\begin{array}{r}0.97624 \\
0.0001\end{array}$ \\
\hline \multirow[t]{2}{*}{ TOTVG } & $\begin{array}{r}0.76553 \\
0.0002\end{array}$ & $\begin{array}{r}0.61260 \\
0 \quad 0069\end{array}$ & $\begin{array}{r}070145 \\
0.0012\end{array}$ & $\begin{array}{r}070351 \\
0 \quad 0011\end{array}$ & $\begin{array}{r}0 \quad 69318 \\
0 \quad 0014\end{array}$ & $\begin{array}{r}091412 \\
0 \quad 0001\end{array}$ & $\begin{array}{r}0 \quad 92975 \\
0 \quad 0001\end{array}$ & $\begin{array}{r}096901 \\
0 \quad 0001\end{array}$ & $\begin{array}{r}095558 \\
0 \quad 0001\end{array}$ \\
\hline & NEFRT & TUN1 & TUN2 & TUN 1 N2 & TCAPN 1 & TCAPN2 & TCAPNIN2 & TEFRT & \\
\hline HOSTVG & $\begin{array}{r}0.41061 \\
0.0905\end{array}$ & $\begin{array}{r}0.80979 \\
0.0001\end{array}$ & $\begin{array}{r}0.73079 \\
0.0006\end{array}$ & $\begin{array}{r}0.76276 \\
0.0002\end{array}$ & $\begin{array}{r}0.55095 \\
0.0178\end{array}$ & $\begin{array}{r}0.51976 \\
0.0270\end{array}$ & $\begin{array}{r}0 \quad 52184 \\
0.0263\end{array}$ & $\begin{array}{r}0.53640 \\
0.0217\end{array}$ & \\
\hline NODEVG & $\begin{array}{r}0.97624 \\
0.0001\end{array}$ & $\begin{array}{r}0.79029 \\
0.0001\end{array}$ & $\begin{array}{r}0.83574 \\
0.0001\end{array}$ & $\begin{array}{r}0.81024 \\
0.0001\end{array}$ & $\begin{array}{r}0.95661 \\
0.0001\end{array}$ & $\begin{array}{r}0.95971 \\
0 \quad 0001\end{array}$ & $\begin{array}{r}0 \quad 96384 \\
0 \quad 0001\end{array}$ & $\begin{array}{r}0.96798 \\
0.0001\end{array}$ & \\
\hline TOTVG & $\begin{array}{r}0.94525 \\
0.0001\end{array}$ & $\begin{array}{r}0.85021 \\
0.0001\end{array}$ & $\begin{array}{r}0.89360 \\
0.0001\end{array}$ & $\begin{array}{r}0.87332 \\
0.0001\end{array}$ & $\begin{array}{r}097934 \\
0 \quad 0001\end{array}$ & $\begin{array}{r}097004 \\
0.0001\end{array}$ & $\begin{array}{r}0 \quad 97417 \\
0 \quad 0001\end{array}$ & $\begin{array}{r}0 \quad 98037 \\
0 \quad 0001\end{array}$ & \\
\hline
\end{tabular}


7 'WITH' Variables HMSGSND 17 'VAR' Variables. HUN $\begin{array}{ll}\text { HMSGREC } & \text { NMSGSND } \\ \text { HUN2 } & \text { HCAPN1 } \\ \text { TCAPN1 } & \text { TCAPN2 }\end{array}$

Correlation Analysis

$\begin{array}{llll}\text { NMSGREC } & \text { TMSGSND } & \text { TMSGREC } & \text { TCOMMSG } \\ \text { HCAPN2 } & \text { HEFRT } & \text { NUN1 } & \text { NUN2 }\end{array}$ TCAPNIN2 TEFRT
NCAPN 1
NEFRT

TUN 1

TUN2
Simple Statistics

VaTIable
HMSGSND
HMSGREC
NMSGSND
NMSGREC
TMSGSND
TMSGREC
TCOMMSG
HUN1
HUN2
HCAPN1
HCAPN2
HEFRT
NUN1
NUN2
NCAPN1
NCAPN2
NEFRT
TUN1
TUN2
TUNIN2
TCAPN1
TCAPN2
TCAPN1N2
TEFRT

$\begin{array}{rr}\text { Std Dev } & \text { Median } \\ 2803476 & 4500000 \\ 1.144752 & 2000000 \\ 6.641128 & 9000000 \\ 6.921596 & 10000000 \\ 7.270003 & 13000000 \\ 7.196813 & 13.000000 \\ 14.418126 & 27.000000 \\ 11.642833 & 35.000000 \\ 25.840891 & 54.500000 \\ 25.123880 & 249000000 \\ 22.758757 & 143.500000 \\ 362591 & 129673 \\ 12.701320 & 46.000000 \\ 40.744742 & 69.500000 \\ 10.268844 & 687.000000 \\ 65.025521 & 412.000000 \\ 3679114 & 1054636 \\ 22.367182 & 83.000000 \\ 61.622003 & 127.000000 \\ 83.223300 & 211.500000 \\ 08.642017 & 1193.500000 \\ 11.298478 & 720.500000 \\ 17.423937 & 1889.000000 \\ 5339407 & 3614345\end{array}$
Minımum
1 onosion
20000010
2.000000
3000000
3.000000
6.000000
23.000000
19.000000
69000000
36.000000
12337
27.000000
27.000000
26.000000
151.000000
80.000000
56230
50.000000
56.000000
106.000000
274.000000
142.000000
180012

Max imum

9000000 5000000 32000000 $\begin{array}{ll}33 & 000000\end{array}$ 35.000000
35000000 70.000000 61000000 113.000000 827000000 46000000 1140590 73000000 190.000000 2565000000 00000000 13686523 134000000 303.000000 437.000000
2824 2824.000000 1764.000000 $\begin{array}{r}18474019 \\ \hline\end{array}$ 
Correlation Analysis

Spearman Correlation Coefficients / Prob > $|R|$ under Ho Rho=0/ $N=18$

\begin{tabular}{|c|c|c|c|c|c|c|c|c|c|}
\hline & HUN 1 & HUN2 & HCAPN 1 & HCAPN2 & HEFRT & NUN 1 & NUN2 & NCAPN 1 & NCAPN 2 \\
\hline HMSGSND & $\begin{array}{r}0.59908 \\
0.0086\end{array}$ & $\begin{array}{r}0 \quad 63958 \\
0 \quad 0043\end{array}$ & $\begin{array}{r}0.69696 \\
0.0013\end{array}$ & $\begin{array}{r}070740 \\
0 \quad 0010\end{array}$ & $\begin{array}{r}0 \quad 69905 \\
0 \quad 0012\end{array}$ & $\begin{array}{r}0.06792 \\
0.7889\end{array}$ & $\begin{array}{r}0 \quad 10016 \\
0.6925\end{array}$ & $\begin{array}{r}0 \quad 13668 \\
0 \quad 5886\end{array}$ & $\begin{array}{r}0 \quad 08660 \\
0 \quad 7326\end{array}$ \\
\hline HMSGREC & $\begin{array}{r}0.65912 \\
0.0029\end{array}$ & $\begin{array}{l}064956 \\
-0.0035\end{array}$ & $\begin{array}{r}069439 \\
0.0014\end{array}$ & $\begin{array}{r}0 \quad 64628 \\
0 \quad 0038\end{array}$ & $\begin{array}{r}0 \quad 63972 \\
0 \quad 0042\end{array}$ & $\begin{array}{r}071300 \\
0 \quad 0009\end{array}$ & $\begin{array}{r}070533 \\
0 \quad 0011\end{array}$ & $\begin{array}{r}0 \quad 61019 \\
0 \quad 0072\end{array}$ & $\begin{array}{r}0 \quad 62988 \\
0 \quad 0051\end{array}$ \\
\hline NMSGSND & $\begin{array}{r}0 \quad 37416 \\
0 \quad 1261\end{array}$ & $\begin{array}{r}0.51796 \\
0.0277\end{array}$ & $\begin{array}{r}050860 \\
0.0311\end{array}$ & $\begin{array}{r}048259 \\
0.0425\end{array}$ & $\begin{array}{r}040355 \\
0 \quad 0968\end{array}$ & $\begin{array}{r}0 \quad 61043 \\
0.0071\end{array}$ & $\begin{array}{r}0 \quad 67709 \\
0 \quad 0020\end{array}$ & $\begin{array}{r}0 \quad 67085 \\
0 \quad 0023\end{array}$ & $\begin{array}{r}0 \quad 68749 \\
0 \quad 0016\end{array}$ \\
\hline NMSGREC & $\begin{array}{r}058384 \\
0.0110\end{array}$ & $\begin{array}{r}0.78458 \\
0.0001\end{array}$ & $\begin{array}{r}0.77720 \\
0.0001\end{array}$ & $\begin{array}{r}077825 \\
0.0001\end{array}$ & $\begin{array}{r}0 \quad 70127 \\
0 \quad 0012\end{array}$ & $\begin{array}{r}0.36333 \\
0.1383\end{array}$ & $\begin{array}{r}0.41233 \\
0.0891\end{array}$ & $\begin{array}{r}0.52833 \\
0.0242\end{array}$ & $\begin{array}{r}0.50829 \\
0.0313\end{array}$ \\
\hline TMSGSND & $\begin{array}{r}062091 \\
0.0060\end{array}$ & $\begin{array}{r}0.74106 \\
0.0004\end{array}$ & $\begin{array}{r}0.77842 \\
0.0001\end{array}$ & $\begin{array}{r}0.78050 \\
0.0001\end{array}$ & $\begin{array}{r}070370 \\
0 \quad 0011\end{array}$ & $\begin{array}{r}0.52287 \\
0.0260\end{array}$ & $\begin{array}{r}0 \quad 58745 \\
0.0104\end{array}$ & $\begin{array}{r}0.62274 \\
0.0058\end{array}$ & $\begin{array}{r}0.60094 \\
0.0083\end{array}$ \\
\hline TMSGREC & $\begin{array}{r}0.65484 \\
0 \quad 0032\end{array}$ & $\begin{array}{r}0.80590 \\
0.0001\end{array}$ & $\begin{array}{r}0.79755 \\
0.0001\end{array}$ & $\begin{array}{r}0.78293 \\
0.0001\end{array}$ & $\begin{array}{r}070986 \\
0.0010\end{array}$ & $\begin{array}{r}0 \quad 57504 \\
0.0125\end{array}$ & $\begin{array}{r}0.62739 \\
0 \quad 0053\end{array}$ & $\begin{array}{r}071717 \\
0.0008\end{array}$ & $\begin{array}{r}070986 \\
0.0010\end{array}$ \\
\hline \multirow[t]{2}{*}{ TCOMMSG } & $\begin{array}{r}0 \quad 64535 \\
0.0038\end{array}$ & $\begin{array}{r}0.80541 \\
0.0001\end{array}$ & $\begin{array}{r}0.80956 \\
0.0001\end{array}$ & $\begin{array}{r}0.80333 \\
0.0001\end{array}$ & $\begin{array}{r}0.72238 \\
0.0007\end{array}$ & $\begin{array}{r}0.54210 \\
0.0201\end{array}$ & $\begin{array}{r}059887 \\
0.0086\end{array}$ & $\begin{array}{r}0 \quad 65907 \\
0.0029\end{array}$ & $\begin{array}{r}064246 \\
0.0040\end{array}$ \\
\hline & NEFRT & TUN1 & TUN2 & TUNIN2 & TCAPN 1 & TCAPN2 & TCAPN1N2 & TEFRT & \\
\hline HMSGSND & $\begin{array}{r}0 \quad 05008 \\
0.8436\end{array}$ & $\begin{array}{r}0.42152 \\
0 \quad 0815\end{array}$ & $\begin{array}{r}0.37665 \\
0.1234\end{array}$ & $\begin{array}{r}0.41412 \\
0.0875\end{array}$ & $\begin{array}{r}020450 \\
0.4157\end{array}$ & $\begin{array}{r}0 \quad 19093 \\
0.4479\end{array}$ & $\begin{array}{r}0 \quad 18572 \\
0 \quad 4606\end{array}$ & $\begin{array}{r}0 \quad 18259 \\
0 \quad 4683\end{array}$ & \\
\hline HMSGREC & $\begin{array}{r}0.62222 \\
0.0058\end{array}$ & $\begin{array}{r}0.72392 \\
0.0007\end{array}$ & $\begin{array}{r}0.76001 \\
0.0003\end{array}$ & $\begin{array}{r}0.77885 \\
0.0001\end{array}$ & $\begin{array}{r}068893 \\
0.0016\end{array}$ & $\begin{array}{r}0.66378 \\
0.0027\end{array}$ & $\begin{array}{r}067799 \\
0.0020\end{array}$ & $\begin{array}{r}0.65721 \\
0.0030\end{array}$ & \\
\hline NMSGSND & $\begin{array}{r}0.67189 \\
0.0023\end{array}$ & $\begin{array}{r}0.50132 \\
0.0341\end{array}$ & $\begin{array}{r}0.66045 \\
0.0029\end{array}$ & $\begin{array}{r}0.63042 \\
0.0050\end{array}$ & $\begin{array}{r}0.75197 \\
0.0003\end{array}$ & $\begin{array}{r}0.72389 \\
0.0007\end{array}$ & $\begin{array}{r}0.73429 \\
0.0005\end{array}$ & $\begin{array}{r}0.70205 \\
0.0012\end{array}$ & \\
\hline NMSGREC & $\begin{array}{r}046189 \\
0.0536\end{array}$ & $\begin{array}{r}0.53465 \\
0.0223\end{array}$ & $\begin{array}{r}0.63589 \\
0.0046\end{array}$ & $\begin{array}{r}063549 \\
0.0046\end{array}$ & $\begin{array}{r}0 \quad 61374 \\
0.0067\end{array}$ & $\begin{array}{r}0.61163 \\
0.0070\end{array}$ & $\begin{array}{r}0 \quad 61163 \\
0.0070\end{array}$ & $\begin{array}{r}0.59476 \\
0.0092\end{array}$ & \\
\hline TMSGSND & $\begin{array}{r}0.57084 \\
0.0134\end{array}$ & $\begin{array}{r}0.61651 \\
0.0064\end{array}$ & $\begin{array}{r}0.71719 \\
0.0008\end{array}$ & $\begin{array}{r}070390 \\
0.0011\end{array}$ & $\begin{array}{r}071511 \\
0.0009\end{array}$ & $\begin{array}{r}068917 \\
0.0016\end{array}$ & $\begin{array}{r}0.69643 \\
0 \quad 0013\end{array}$ & $\begin{array}{r}0 \quad 67256 \\
0.0022\end{array}$ & \\
\hline TMSGREC & $\begin{array}{r}0 \quad 66706 \\
0.0025\end{array}$ & $\begin{array}{r}0.66393 \\
0.0027\end{array}$ & $\begin{array}{r}0.78502 \\
0.0001\end{array}$ & $\begin{array}{r}0.77956 \\
0.0001\end{array}$ & $\begin{array}{r}0.79859 \\
0.0001\end{array}$ & $\begin{array}{r}079024 \\
0.0001\end{array}$ & $\begin{array}{r}079650 \\
0.0001\end{array}$ & $\begin{array}{r}0.77876 \\
0.0001\end{array}$ & 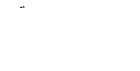 \\
\hline TCOMMSG & $\begin{array}{r}0 \quad 60717 \\
0 \quad 0075\end{array}$ & $\begin{array}{r}0.64765 \\
0.0037\end{array}$ & $\begin{array}{r}075870 \\
0 \quad 0003\end{array}$ & $\begin{array}{r}075066 \\
0.0003\end{array}$ & $\begin{array}{r}075248 \\
0.0003\end{array}$ & $\begin{array}{r}073483 \\
0.0005\end{array}$ & $\begin{array}{r}074417 \\
0.0004\end{array}$ & $\begin{array}{r}0.71926 \\
0 \quad 0008\end{array}$ & \\
\hline
\end{tabular}




\begin{tabular}{|c|c|c|c|}
\hline $\begin{array}{l}6 \text { 'WI TH' } \\
7 \text { 'VAR' }\end{array}$ & $\begin{array}{l}\text { Variables } \\
\text { Variables. }\end{array}$ & $\begin{array}{l}\text { RIU } \\
\text { HUN1 } \\
\text { TUN1N2 }\end{array}$ & $\begin{array}{l}\text { R1T } \\
\text { HUN2 } \\
\text { TCAPN }\end{array}$ \\
\hline & Variable & & $\mathrm{N}$ \\
\hline & RIU & & 18 \\
\hline & RIT & & 18 \\
\hline & R2U & & 18 \\
\hline & R2T & & 18 \\
\hline & R3u & & 18 \\
\hline & R3T & & 18 \\
\hline & HUNI & & 18 \\
\hline & HUN2 & & 18 \\
\hline & HCAPN 1 & & 18 \\
\hline & HCAPN2 & & 18 \\
\hline & HEFRT & & 18 \\
\hline & NUNI & & 18 \\
\hline & NUN2 & & 18 \\
\hline & NCAPN 1 & & 18 \\
\hline & NCAPN2 & & 18 \\
\hline & NEFRT & & 18 \\
\hline & TUN1 & & 18 \\
\hline & TUN2 & & 18 \\
\hline & TUNIN2 & & 18 \\
\hline & TCAPN 1 & & 18 \\
\hline & TCAPN2 & & 18 \\
\hline & TCAPN $1 N 2$ & & 18 \\
\hline & TEFRT & & 18 \\
\hline
\end{tabular}

Correlation Analysis

$\begin{array}{lllllllll}\text { R2U } & \text { R2T } & \text { R3U } & \text { R3T } & \text { NUN2 } & \text { NCAPN1 } & \text { NCAPN2 } & \text { NEFRT } & \text { TUN1 } \\ \text { HCAPN1 } & \text { HCAPN2 } & \text { HEFRT } & \text { NUN1 } & \text { NUN2 } \\ \text { TCAPN2 } & \text { TCAPN1N2 } & \text { TEFRT } & & & & \end{array}$

\section{Simple Statistics}

\begin{tabular}{|c|c|}
\hline & Mean \\
\hline 1342 & $\begin{array}{r}900000 \\
21311\end{array}$ \\
\hline 1439 & 194444 \\
\hline & 21741 \\
\hline 1238 & 461111 \\
\hline & 19770 \\
\hline 37. & .555556 \\
\hline 55 & 888889 \\
\hline 338 & 944444 \\
\hline 188. & .777778 \\
\hline & 302424 \\
\hline 44 & 500000 \\
\hline 72. & .388889 \\
\hline 942. & .222222 \\
\hline 591 & 833333 \\
\hline & $\begin{array}{l}2813805 \\
.055556\end{array}$ \\
\hline 128. & .277778 \\
\hline 210. & .333333 \\
\hline 1281 & 166667 \\
\hline 780 & 6111111 \\
\hline 2061 & $\begin{array}{r}.777778 \\
5209993\end{array}$ \\
\hline
\end{tabular}

Std Dev

Median

Minimum

Max rmum

732644191

1326050000

296700000

3234100000

$696 \quad 135651$

$1424 \quad \begin{array}{r}18777 \\ 650000\end{array}$

610400000

7000000

$\begin{array}{rrr}15753 & 19021 \\ 624.101364 & 1223250000 \\ 14487 & 17229\end{array}$

14487

000000

505800000
2821800000

11.642833

35.000000
54.500000

821.800000

23.000000
19000000

25840891
225123880

249.000000

143500000

$\begin{array}{r}129673 \\ \hline\end{array}$

362591
701320

46.000000

$40744742-68700000$

$465.025521 \quad 412000000$

1054636

3 000000

223679114

61.622003

83.223300

808642017

127.000000

69000000

36.000000

$27 \quad \begin{array}{r}12337 \\ 27\end{array}$

26000000

151000000

80000000

56230

56230

56.000000

106.000000

274.000000

142.000000

889.000000

416000000

180012

3444500000

51397

50000

3022.500000

49388

61000000

827.000000

446000000

1140590

1140590

73.000000
190.000000

2565.000000

1608.000000

13686523

34.000000

303000000

437.000000

2824000000

1764.000000

4588.000000

18474019 
Correlation Analysis

Spearman Correlation Coefficients / Prob $>|R|$ under Ho. Rho=0/ $N=18$

\begin{tabular}{|c|c|c|c|c|c|c|c|c|c|}
\hline & HUN 1 & HUN2 & HCAPN 1 & HCAPN2 & HEFRT & NUN 1 & NUN2 & NCAPN 1 & NCAPN 2 \\
\hline RIU & $\begin{array}{r}0.73113 \\
00006\end{array}$ & $\begin{array}{r}074200 \\
0.0004\end{array}$ & $\begin{array}{r}076883 \\
0.0002\end{array}$ & $\begin{array}{r}075232 \\
0.0003\end{array}$ & $\begin{array}{r}071930 \\
0 \quad 0008\end{array}$ & $\begin{array}{r}058398 \\
0.0109\end{array}$ & $\begin{array}{r}0 \quad 61610 \\
0 \quad 0065\end{array}$ & $\begin{array}{r}0 \quad 66770 \\
0 \quad 0025\end{array}$ & $\begin{array}{r}0.64912 \\
0.0036\end{array}$ \\
\hline$R 1 T$ & $\begin{array}{r}072596 \\
0.0006\end{array}$ & $\begin{array}{r}066563 \\
0.0026\end{array}$ & $\begin{array}{r}0.72343 \\
0 \quad 0007\end{array}$ & $\begin{array}{r}071723 \\
0 \quad 0008\end{array}$ & $\begin{array}{r}0 \quad 69040 \\
0 \quad 0015\end{array}$ & $\begin{array}{r}090646 \\
0 \quad 0001\end{array}$ & $\begin{array}{r}091950 \\
0 \quad 0001\end{array}$ & $\begin{array}{r}098349 \\
0 \quad 0001\end{array}$ & $\begin{array}{r}097936 \\
0.0001\end{array}$ \\
\hline$R 2 U$ & $\begin{array}{r}091520 \\
0.0001\end{array}$ & $\begin{array}{r}085965 \\
0 \quad 0001\end{array}$ & $\begin{array}{r}088854 \\
0 \quad 0001\end{array}$ & $\begin{array}{r}0 \quad 87203 \\
0 \quad 0001\end{array}$ & $\begin{array}{r}087203 \\
0 \quad 0001\end{array}$ & $\begin{array}{r}084548 \\
0 \quad 0001\end{array}$ & $\begin{array}{r}0 \quad 88854 \\
0 \quad 0001\end{array}$ & $\begin{array}{r}084314 \\
0 \quad 0001\end{array}$ & $\begin{array}{r}082250 \\
0 \quad 0001\end{array}$ \\
\hline$R 2 T$ & $\begin{array}{r}0.72596 \\
0 \quad 0006\end{array}$ & $\begin{array}{r}0.66563 \\
0.0026\end{array}$ & $\begin{array}{r}072343 \\
0.0007\end{array}$ & $\begin{array}{r}071723 \\
0.0008\end{array}$ & $\begin{array}{r}0 \quad 69040 \\
0.0015\end{array}$ & $\begin{array}{r}090646 \\
0 \quad 0001\end{array}$ & $\begin{array}{r}091950 \\
0 \quad 0001\end{array}$ & $\begin{array}{r}0 \quad 98349 \\
0 \quad 0001\end{array}$ & $\begin{array}{r}0.97936 \\
0.0001\end{array}$ \\
\hline R3u & $\begin{array}{r}0.91464 \\
0.0001\end{array}$ & $\begin{array}{r}0.85906 \\
0.0001\end{array}$ & $\begin{array}{r}088591 \\
0.0001\end{array}$ & $\begin{array}{r}086939 \\
0.0001\end{array}$ & $\begin{array}{r}0.86939 \\
0.0001\end{array}$ & $\begin{array}{r}084747 \\
0.0001\end{array}$ & $\begin{array}{r}0 \quad 89004 \\
0 \quad 0001\end{array}$ & $\begin{array}{r}0.84151 \\
0 \quad 0001\end{array}$ & $\begin{array}{r}0.81982 \\
0.0001\end{array}$ \\
\hline \multirow[t]{2}{*}{ R3T } & $\begin{array}{r}0.72596 \\
0.0006\end{array}$ & $\begin{array}{r}0.66563 \\
0.0026\end{array}$ & $\begin{array}{r}0.72343 \\
0.0007\end{array}$ & $\begin{array}{r}071723 \\
0.0008\end{array}$ & $\begin{array}{r}069040 \\
0.0015\end{array}$ & $\begin{array}{r}090646 \\
0 \quad 0001\end{array}$ & $\begin{array}{r}0 \quad 91950 \\
0 \quad 0001\end{array}$ & $\begin{array}{r}098349 \\
0 \quad 0001\end{array}$ & $\begin{array}{r}0.97936 \\
0.0001\end{array}$ \\
\hline & NEFRT & TUN 1 & TUN2 & TUN1N2 & TCAPN 1 & TCAPN 2 & TCAPN 1 N2 & TEFRT & \\
\hline RIU & $\begin{array}{r}062023 \\
0.0060\end{array}$ & $\begin{array}{r}0.68627 \\
0.0017\end{array}$ & $\begin{array}{r}0.74613 \\
0.0004\end{array}$ & $\begin{array}{r}0.75103 \\
0.0003\end{array}$ & $\begin{array}{r}071723 \\
0.0008\end{array}$ & $\begin{array}{r}0.70485 \\
0.0011\end{array}$ & $\begin{array}{r}071104 \\
0.0009\end{array}$ & $\begin{array}{r}070691 \\
0.0010\end{array}$ & \\
\hline RIT & $\begin{array}{r}0.96904 \\
0.0001\end{array}$ & $\begin{array}{r}082456 \\
0.0001\end{array}$ & $\begin{array}{r}0.90506 \\
0.0001\end{array}$ & $\begin{array}{r}0.87913 \\
0.0001\end{array}$ & $\begin{array}{r}0.99587 \\
0.0001\end{array}$ & $\begin{array}{r}099794 \\
0.0001\end{array}$ & $\begin{array}{r}100000 \\
00001\end{array}$ & $\begin{array}{r}099794 \\
0.0001\end{array}$ & \\
\hline$R 2 U$ & $\begin{array}{r}0.78947 \\
0.0001\end{array}$ & $\begin{array}{r}0.96698 \\
0.0001\end{array}$ & $\begin{array}{r}0.99174 \\
0.0001\end{array}$ & $\begin{array}{r}0.99897 \\
0.0001\end{array}$ & $\begin{array}{r}0.89267 \\
0.0001\end{array}$ & $\begin{array}{r}088235 \\
0.0001\end{array}$ & $\begin{array}{r}088854 \\
0 \quad 0001\end{array}$ & $\begin{array}{r}0.88442 \\
0 \quad 0001\end{array}$ & \\
\hline$R 2 T$ & $\begin{array}{r}0.96904 \\
0.0001\end{array}$ & $\begin{array}{r}0.82456 \\
0.0001\end{array}$ & $\begin{array}{r}0.90506 \\
0.0001\end{array}$ & $\begin{array}{r}087913 \\
0.0001\end{array}$ & $\begin{array}{r}099587 \\
0.0001\end{array}$ & $\begin{array}{r}099794 \\
0.0001\end{array}$ & $\begin{array}{r}1 \quad 00000 \\
0 \quad 0001\end{array}$ & $\begin{array}{r}099794 \\
0 \quad 0001\end{array}$ & \\
\hline R3u & $\begin{array}{r}078678 \\
0 \quad 0001\end{array}$ & $\begin{array}{r}096644 \\
0.0001\end{array}$ & $\begin{array}{r}0.99329 \\
0.0001\end{array}$ & $\begin{array}{r}0 \quad 99948 \\
0 \quad 0001\end{array}$ & $\begin{array}{r}0 \quad 89107 \\
0 \quad 0001\end{array}$ & $\begin{array}{r}0 \quad 87971 \\
0 \quad 0001\end{array}$ & $\begin{array}{r}088591 \\
0 \quad 0001\end{array}$ & $\begin{array}{r}088178 \\
0.0001\end{array}$ & \\
\hline R3T & $\begin{array}{r}0.96904 \\
0.0001\end{array}$ & $\begin{array}{r}0.82456 \\
0.0001\end{array}$ & $\begin{array}{r}0.90506 \\
0.0001\end{array}$ & $\begin{array}{r}087913 \\
0.0001\end{array}$ & $\begin{array}{r}0.99587 \\
0.0001\end{array}$ & $\begin{array}{r}099794 \\
0.0001\end{array}$ & $\begin{array}{r}100000 \\
0 \quad 0001\end{array}$ & $\begin{array}{r}099794 \\
0 \quad 0001\end{array}$ & \\
\hline
\end{tabular}




\section{Correlation Analysis}

$\begin{array}{lllll}3 & \text { 'WITH' Variables: HOSTVG NODEVG } & \text { TOTVG } \\ 3 \text { 'VAR' Variables: HOSTVG } & \text { NODEVG } & \text { TOTVG }\end{array}$

Variable

HOSTVG

NODTVG

TOTVG

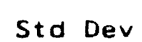

Median

7.000000
35.000000
52500000

Minimum

Max ımum

$\mathrm{N} \quad$ Mean

$14 \quad 444444$

$57 \quad 666667$

14.455702

49413025

$\begin{array}{llllll}18 & 72111111 & 53198727 & 52500000 & 10000000 & 158000000\end{array}$

2000000

6000000

$\begin{array}{llllll}18 & 72111111 & 53198727 & 52500000 & 10000000 & 158000000\end{array}$

47000000

152000000

Spearman Correlation Coefficients / Prob $>|R|$ under Ho: Rho=0/ $N=18$

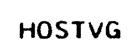

NODEVG

TOTVG

HOSTVG

100000

0.44642

0.0633

0.60875

NODEVG

044642
$0 \quad 0633$

1.00000

$$
00
$$

0 96691

TOTVG

0.60875
$0 \quad 0073$

0 96691

0.0001

1.00000

0.0 
Correlation Analysis

7 'WITH' Varrables. HMSGSND HMSGREC NMSGSND NMSGREC TMSGSND TMSGREC TCOMMSG
3 'VAR' Variables: HOSTVG NODEVG TOTVG

Simple Statistics

\begin{tabular}{|c|c|c|c|c|c|c|}
\hline Variable & $N$ & Mean & Std Dev & Median & Minimum & Maximum \\
\hline HMSGSND & 18 & $\begin{array}{l}4.277778 \\
2.617\end{array}$ & $\begin{array}{r}2003476 \\
1 \quad 144752\end{array}$ & $\begin{array}{l}4.500000 \\
2.000000\end{array}$ & 1000000 & $\begin{array}{ll}9 & 000000 \\
5 & 000000\end{array}$ \\
\hline $\begin{array}{l}\text { HMSGREC } \\
\text { NMSGSND }\end{array}$ & $\begin{array}{l}18 \\
18\end{array}$ & $\begin{array}{llll}2 & 611111 \\
8 & 888889\end{array}$ & $\begin{array}{ll}1 & 144752 \\
6 & 641128\end{array}$ & $\begin{array}{l}2000000 \\
9.000000\end{array}$ & $\begin{array}{ll}1 & 000000 \\
2 & 000000\end{array}$ & $\begin{array}{r}5.000000 \\
32000000\end{array}$ \\
\hline NMSGREC & 18 & 10555556 & 6921596 & 10.000000 & 2000000 & 33000000 \\
\hline TMSGSND & 18 & 13.166667 & 7.270003 & 13.000000 & 3.000000 & 35.000000 \\
\hline TMSGREC & 18 & 13.166667 & 7.196813 & 13.000000 & 3000000 & 35.000000 \\
\hline TCOMMSG & 18 & 26.333333 & 14.418126 & 27.000000 & 6000000 & 70.000000 \\
\hline HOSTVG & 18 & 14.444444 & 14.455702 & 7.000000 & 2.000000 & 47.000000 \\
\hline NODEVG & 18 & 57.666667 & $49 \quad 413025$ & 35.000000 & 6.000000 & 152000000 \\
\hline TOTVG & 18 & 72.11111 & 53.198727 & 52.500000 & 10.000000 & 158.000000 \\
\hline
\end{tabular}

Spearman Correlation Coefficients / Prob > $|R|$ under Ho: Rho=0/ $N=18$

$\begin{array}{lrrr} & \text { HOSTVG } & \text { NODEVG } & \text { TOTVG } \\ \text { HMSGSND } & 0.73569 & 0.03133 & 0.19844 \\ & 0.0005 & 0.9018 & 0.4299 \\ \text { HMSGREC } & 0.45052 & 0.62505 & 0.62834 \\ & 0.0606 & 0.0055 & 0.0052 \\ \text { NMSGSND } & 0.22106 & 0.66998 & 0.66998 \\ & 0.3780 & 0.0023 & 0.0023 \\ \text { NMSGREC } & 058317 & 0.44020 & 0.55632 \\ & 0.0111 & 0.0675 & 0.0165 \\ \text { TMSGSND } & 058285 & 0.55429 & 0.64884 \\ & 0.0111 & 0.0170 & 0.0036 \\ \text { TMSGREC } & 056362 & 0.64894 & 0.73358 \\ & 0.0149 & 0.0036 & 0.0005 \\ \text { TCOMMSG } & 0.56665 & 0.59221 & 0.67949 \\ & 0.0142 & 0.0096 & 0.0019\end{array}$


6 'WITH' Variables. RIU RIT R2U

$$
\text { Correlation Analysis }
$$

3 'VAR' Variables: HOSTVG NODEVG TOTVG

R2T R3U R3T

\title{
Simple Statistics
}

Variable

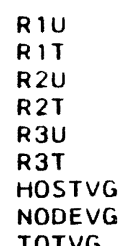

NODEVG

TOTVG
18

18

18
18
18

18

18

\begin{abstract}
Std Dev
\end{abstract}

$732 \quad 644191$
15218
$696 \quad 135651$
15753
624.101364
14487
14.455702
49.413025
53.198727

Median

1326.050000

1424.650000

19021

$1223 \quad 250000$

17229
7000000

35.000000

52500000

$\begin{array}{lll}14 & 444444 & 14.455702 \\ 57 & 666667 & 49.413025 \\ 72 & 111111 & 53.198727\end{array}$
1342900000 21311
72111111

Spearman Correlation Coefficient

$\begin{array}{lr}\text { RIU } & 0.64763 \\ \text { R1T } & 0.0037 \\ & 0.52184 \\ \text { R2U } & 0.0263 \\ \text { R2T } & 0.76405 \\ & 00002 \\ \text { R3U } & 0.52184 \\ & 0.0263 \\ \text { R3T } & 076445 \\ & 0.0002 \\ & 0.52184\end{array}$

RIU

\begin{abstract}
HOSTVG
\end{abstract}
0.0037

0.0263

.52184
0.52184
$0 \quad 0263$ ts / Prob > $|R|$

NODEVG

O 55062

0.0179

0.96384
0.0001

0.82025
0.0001

0.96384

0.0001

$0 \quad 81705$

0000

0.96384
0.0001
Minimum

296700000

610400000

3207000000

505800000

2821.800000

2.000000
6.000000

10.000000
Max imum

3444500000

$3409 \quad 51397$

53797

3022500000

47000000

152.000000

158.000000

under Ho Rho=0/N $=18$

\begin{abstract}
TOTVG
\end{abstract}
$0 \quad 64153$

0.0041

0.97417
0.0001

0.88430

0.0001

0.97417

0.0001

0.88217

0.0001

0.97417 


7 'WITH' Variables: HMSGSND HMSGREC NMSGSND NMSGREC TMSGSND TMSGREC TCOMMSG

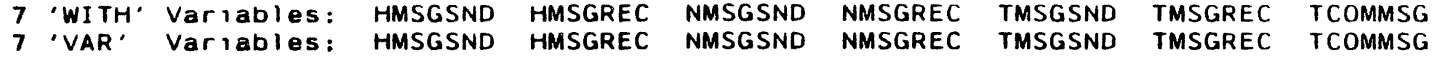

Simple Statistics

\begin{tabular}{|c|c|c|c|c|c|c|}
\hline Variable & $N$ & Mean & Std Dev & Median & Minimum & Maximum \\
\hline HMSGSND & 18 & 4.277778 & 2.803476 & 4500000 & 0 & 9000000 \\
\hline HMSGREC & 18 & 2.611111 & 1144752 & 2.000000 & -1000000 & 5000000 \\
\hline NMSGSND & 18 & B. 888889 & 6.641128 & 9000000 & 2000000 & 32000000 \\
\hline NMSGREC & 18 & 10.555556 & 6.921596 & 10.000000 & 2000000 & 33000000 \\
\hline TMSGSND & 18 & 13.166667 & 7.270003 & 13.000000 & 3.000000 & 35000000 \\
\hline TMSGREC & 18 & 13.166667 & 7.196813 & 13.000000 & 3000000 & 35.000000 \\
\hline TCOMMSG & 18 & 26.333333 & 14.418126 & 27000000 & 6.000000 & 70.000000 \\
\hline
\end{tabular}

Spearman Correlation Coefficients / Prob $>|R|$ under Ho: Rho=0 / $N=18$

$\begin{array}{lc}\text { HMSGSND } & 100000 \\ & 0.0 \\ \text { HMSGREC } & 0.23659 \\ & 0.3445 \\ \text { NMSGSND } & 0.14459 \\ & 0.5670 \\ \text { NMSGREC } & 0.72819 \\ & 0.0006 \\ \text { TMSGSND } & 0.61176 \\ & 0.0070 \\ \text { TMSGREC } & 0.54512 \\ & 00193 \\ \text { TCOMMSG } & 0.57976 \\ & 0.0117\end{array}$

0.23659
0.3445
1.00000
0.0
0.73290
0.0005
0.43412
0.0718
0.59169
0.0097
0.65817
0.0030
0.64338
0.0040

NMSGSND

$0 \quad 14459$

0.5670

0.73290
0.0005

1.00000

0.0

0.62068

0.0060

0.80544

0.0001

0.78328

0.0001

0.80544

0.80544
0.0001
NMSGREC

\begin{abstract}
$0 \quad 72819$
0.0006
\end{abstract}
0.43412
0.0718

0.62068

0.62068
0.0060

1.00000

0.0

090573

0.0001

0.93551
0.0001

0.93278

0.0001
TMSGSND

061176

0.0070
0

0.59169

0.80544

0.0001

0.90573
0.0001

1.00000

0.0

0.91445

0.0001

0.97599

0.97599
0.0001
TMSGREC

$0 \quad 54512$

TCOMMSG

0.57976
0.0117

0.64338

$0 \quad 65817$

0 78328

0.0001

0.93551
0.0001

0.91445

0.91445
$0 \quad 0001$

100000
00

0.97114
0.0001

0.97114
0.0001

080544

0.0001

0.93278
0.0001

0.97599

0.0001

0.97114
0.0001

1.00000

0.0 
Correlation Analysis

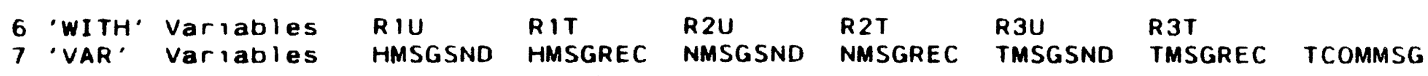

Variable

\begin{tabular}{ll} 
RIU & 18 \\
RIT & 18 \\
R2U & 18 \\
R2T & 18 \\
R3U & 18 \\
R3T & 18 \\
HMSGSND & 18 \\
HMSGREC & 18 \\
NMSGSND & 18 \\
NMSGREC & 18 \\
TMSGSND & 18 \\
TMSGREC & 18 \\
TCOMMSG & 18 \\
\hline
\end{tabular}

$\begin{array}{rr}N & \text { Mean } \\ 18 & 1342.900000 \\ 18 & 21311 \\ 18 & 1439.194444 \\ 18 & 21741 \\ 18 & 19111 \\ 18 & 12384670 \\ 18 & 19770 \\ 18 & 4.277778 \\ 18 & 2.61111 \\ 18 & 8.888889 \\ 18 & 10.555556 \\ 18 & 13.166667 \\ 18 & 13.166667 \\ 18 & 26.333333\end{array}$

Simple Statistics

Spearman Correlation Coefficients / Prob $>|R|$ under Ho. Rho=0/ $N=18$

HMSGSND

RIU

RIT

R2U

R2T

R3U

R3T

18572
$0 \quad 4606$

0.42152
$0 \quad 0815$

$0 \quad 18572$
$0 \quad 4606$

$0 \quad 41234$

.0 .18572
HMSGREC

062988
0.0051

0.67799

0.0020

0.18572
$0 \quad 4606$

076766
0.0002

$0 \quad 67799$
0.0020

0.76806

0.0002

0.67799
0.0020

\begin{abstract}
NMSGSND
\end{abstract}
051588
0.0284

0.73429

0.0005
0.63444
$0 \quad 0047$

0.73429

0.0005

0.63165
0.0049

o 73429
Std Dev

15218
135651

15753

$624 \quad 101364$

14487
.803476

1.144752

6.641128

6.921596

7.270003

7.196813

14.418126

Median
1326.050000
18777
$14: 4 \quad 650000$
19021
$1223 \quad 250000$
17229
4.500000
2.000000
9.000000
10.000000
13.000000
13.000000
27.000000
Minımum
296.700000
610400000
3207000000
505. B00000
2821800000
1.000000
2.000000
3000000
3000000
6000000

Maximum

3444.500000

3409300000

3022500000

.000000

5000000

32.000000

33.000000

70.000000

0460

NMSGREC
0.72553
0.0007
0.61163
0.0070
0.65065
0.0035
0.61163
0.0070
0.64413
0.0039
0.61163
0.0070

TMSGSND
0.75663
0.0003
0.69643
00013
0.70992
0.0010
0.69643
0.0013
070666
0.0010
0.69643

TMSGREC

TCOMMSG

080437

0.0001

$\begin{array}{rr}079650 & 074417 \\ 00001 & 0.0004\end{array}$

079128

0.75767

0.0003

0.74417

079650
$0 \quad 0001$

0.0004

0 78699

00001

0.75442

0.79650

0.75442
0.0003

0.69643
0.0013

00001

074417
0.0004 
$\begin{array}{llllllll}6 & \text { 'WITH' Variables: } & \text { RIU } & \text { RIT } & \text { R2U } & \text { R2T } & \text { R3U } & \text { R3T } \\ 6^{\text {'VAR' }} \text { Variables: } & \text { RIU } & \text { RIT } & \text { R2U } & \text { R2T } & \text { R3U } & \text { R3T }\end{array}$

\section{Simple Statistics}

Variable

RIU

R2U
R2T

R3U

R3T

N

18
18
18
18
18
18

1342.900000

21311

$1439 \quad 194444$

21741
$1238 \quad 461111$
19770
Std Dev

732.644191
15218
696.135651
15753
624.101364
14487
Median

$\begin{array}{rr}1326 & 050000 \\ & 18777 \\ 1424 & 650000 \\ & 19021 \\ 1223 & 250000 \\ 17229\end{array}$

Minimum

296700000 3234100000 610400000 3207000000 505.800000 2821800000
Maximum

3444500000 51397 3409300000 53797 3022500000 49388

Spearman Correlation Coefficients / Prob $>|R|$ under Ho: Rho=0/ $N=18$

RIT

R2U

R2T

R3U

R3T

RIU

1.00000

0.71104

075026

0.71104

0.75168

0.0003 .

0.88854

1.00000

0.88591

1.00000

0.0001

0.0001

1.00000

0.88854

0.0001

0.88854

0

0.0001

0.88854

1.00000
0.0001

1.0000
0.0

0.99948

0.0001

.88591

0.0009

0.88591

0.0003

0.99948

0.0001

0.88591

.00000

071104
0.0009

0.0001

0.88854

0,0001

1.00000

0.0

0.88591

1.00000

0.0001

0.0001

071104

$0 \quad 0009$

1.00000

0.0001

0.88854

1.00000

0.0001

0.88591

0.000

1.00000

0.0 


\section{Correlation Analysis}

$\begin{array}{llllllll}6 & \text { 'WITH' Variables: } & \text { RIU } & \text { R1T } & \text { R2U } & \text { R2T } & \text { R3U } & \text { R3T } \\ 6 \text { 'VAR' } & \text { Variables: } & \text { Q5 } & \text { Q6 } & \text { Q7 } & \text { QB } & \text { Q9 } & \text { Q10 }\end{array}$

Variabie
R1U
R $1 T$
R2U
R2T
R3U
R3T
Q5
Q6
Q7
Q8
Q9
Q10

\section{Simple Statistics}

$\begin{array}{rr}N & \text { Mean } \\ 18 & 1342 \\ 18 & 900000 \\ 18 & 21311 \\ 18 & 1439194444 \\ 18 & 21741 \\ 18 & 1238461111 \\ 18 & 19770 \\ 18 & 13.000000 \\ 18 & 13.055556 \\ 18 & 14.444444 \\ 18 & 14.166667 \\ 18 & 10.888889 \\ 18 & 4.222222\end{array}$

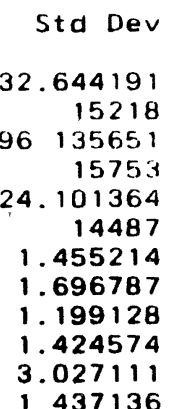

Median
$1326 \quad 050000$
18777
$14 \angle 4 \quad 650000$
19021
1223.250000
17229
14.000000
14.000000
15.000000
15.000000
10.000000
4000000
Mınımum
296.700000 3234100000 610400000 3207000000 505.800000 2821.800000 10.000000 12.000000
12.000000
300000

Max imum

000

Spearman Correlation Coefficients / Prob > $|R|$ under Ho Rho=0/N=18

3444500000
51397
$3409 \quad 300000$
53797
3022.500000
49388
14.000000
15.000000
16000000
16.000000
16.000000
8.000000

\section{Q5}

RIU

0.02002
0.9371

-0.07278
0.7741

$-0.08178$

0.08178
0.7470

$-0.44519$

0.0641

$-049013$

49013
0.0389

$-0.51337$

0.0293

-0.14768
0.5587

0.17367

04907

0.65039

-0.58184
0.0113

0.0035

-0.36845
0.1325

$-0.37708$

0.2879

0.1229

-0 39752

0.1023

0.43246
$0 \quad 0731$

0.65039

-0.51337
0.0293

$-0.58184$

0.0035

0.0389

$-0.37045$

0.36182
0.1401

$0 \quad 1302$

$-0.39161$

0.42587

0.26513
0.2877

$-0.49013$

$-0.51337$

0. 1080

0.0780

$0 \quad 65039$

$-0.58184$

0.0035

Q10

$-0 \quad 08675$

07322

-0 51552

0.0285

-0.37673
$0 \quad 1233$

$-0.51552$

0.0285

-0.36824
0.1327

-0.51552
0.0285 


\section{APPENDIX $\mathrm{H}$}

VARIABLES USED IN THE REGRESSION ANALYSES 
VARIABLE NAMES WITH DESCRIPTIONS USED IN THE

REGRESSION ANALYSIS

\begin{tabular}{|c|c|c|}
\hline VARIABLE NAME & DESCRIPTION & METRIC \\
\hline APLNO & Application Number & None \\
\hline APLNAME & Application Name & None \\
\hline Q5 & Question 5 in the Questionnaire & Subjective \\
\hline Q6 & Question 6 in the Questionnaire & $"$ \\
\hline Q7 & Question 7 in the Questionnaire & $"$ \\
\hline Q8 & Question 8 in the Questionnaire & $"$ \\
\hline Q9 & Question 9 in the Questıonnaire & $"$ \\
\hline Q10 & Question 10 in the Questionnaire & $"$ \\
\hline HEXELNS & Host Executable Lines & Size \\
\hline HBLKLNS & Host Blank Lines & $"$ \\
\hline HCMTLNS & Host Commented Lines & $"$ \\
\hline NEXELNS & Node Executable Lınes & $"$ \\
\hline NBLKLNS & Node Blank Lines & $"$ \\
\hline NCMTLNS & Node Commented Lines & $"$ \\
\hline TEXELNS & Total Executable Lines & $"$ \\
\hline TBLKLNS & Total Blank Lines & $"$ \\
\hline TCMTLNS & Total Commented Lines & $"$ \\
\hline TOTLNS & Total Lines in an Application & $"$ \\
\hline HUN1 & Host Unıque Operators & $\begin{array}{l}\text { Software } \\
\text { Science }\end{array}$ \\
\hline HUN2 & Host Unıque Operands & $"$ \\
\hline HCAPN1 & Host Total Operators & $"$ \\
\hline HCAPN2 & Host Total Operands & $"$ \\
\hline
\end{tabular}




\begin{tabular}{|c|c|c|}
\hline HEFRT & Host Effort (E) & $"$ \\
\hline NUN1 & Node Unıque Operators & $"$ \\
\hline NUN2 & Node Unıque Operands & $"$ \\
\hline NCAPN1 & Node Total Operators & $"$ \\
\hline NCAPN2 & Node Total Operands & $"$ \\
\hline NEFRT & Node Effort (E) & $"$ \\
\hline TUN1 & Total Unique Operators & $"$ \\
\hline TUN2 & Total Unıque Operands & $"$ \\
\hline TUN1N2 & Total Unıque Operators \& Operands & $"$ \\
\hline TCAPN1 & Total Operators & $"$ \\
\hline TCAPN2 & Total Operands & $"$ \\
\hline TCAPN1N2 & Total Operators \& Operands & $"$ \\
\hline TEFRT & Total Effort (E) & $"$ \\
\hline HOSTVG & Host Cyclomatic Complexity & $\begin{array}{l}\text { Cyclomatic } \\
\text { Complexity }\end{array}$ \\
\hline NODEVG & Node Cyclomatic Complexity & $"$ \\
\hline TOTVG & Total Cyclomatıc Complexity & $"$ \\
\hline HMSGSND & Host Message Send statements & $\begin{array}{c}\text { Communication } \\
\text { Complexity }\end{array}$ \\
\hline HMSGREC & Host Message Receive statements & $"$ \\
\hline NMSGSND & Node Message Send statements & $"$ \\
\hline NMSGREC & Node Message Receive statements & $"$ \\
\hline TMSGSND & Total Message Send statements & $"$ \\
\hline TMSGREC & Total Message Receive statements & $"$ \\
\hline TCOMMSG & Total Message statements (Send \& Receive) & $"$ \\
\hline R1U & Unıque Operators + Unique Operands & $\begin{array}{l}\text { Resıdual } \\
\text { Complexity }\end{array}$ \\
\hline R1T & Total Operators + Total Operands & $"$ \\
\hline
\end{tabular}




\begin{tabular}{|l|l|l|}
\hline R2U & $\begin{array}{l}\text { Host Unıque Operators \& Operands + } \\
\text { Node Unique Operators \& Operands }\end{array}$ & \\
\hline R2T & $\begin{array}{l}\text { Host Total Operators \& Operands + } \\
\text { Node Total Operators \& Operands }\end{array}$ & \\
\hline R3U & $\begin{array}{l}\text { Host Unique Operators + Host Unıque Operands } \\
+ \text { Node Unique Operators + Node Unique Operands } \\
\text { Host Total Operators + Host Total Operands } \\
+ \text { Node Total Operators + Node Total Operands }\end{array}$ & \\
\hline
\end{tabular}


APPENDIX I

REGRESSION ANALYSES 
Stepwise Procedure for Dependent Variable 09

Step 1 Variable NEXELNS Entered R-square $=0.33814370 \quad C(p)=755116459$

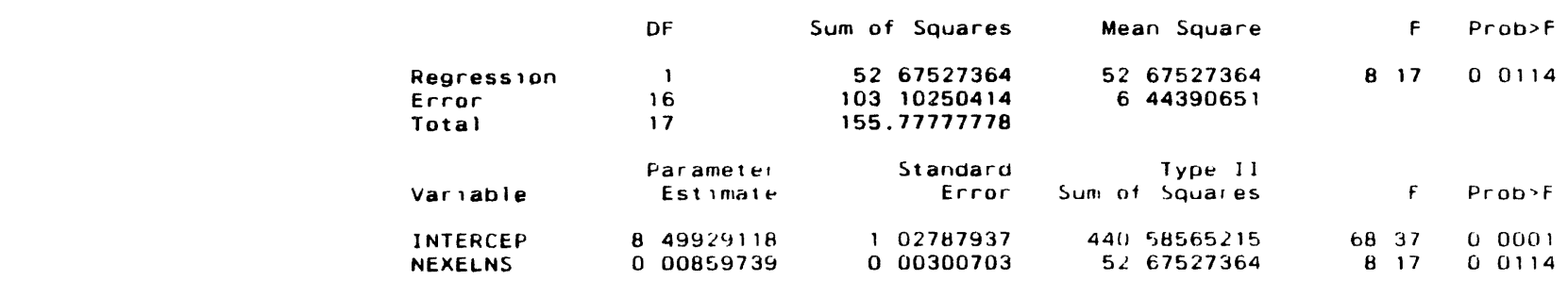

Bounds on condition number. 1.

$C(p)=844684259$

Step 2 Variable HCMTLNS Entered R-squar

\begin{tabular}{|c|c|c|c|c|c|c|c|}
\hline & DF & Sum of & f Squares & Mean Square & & $\mathrm{F}$ & Prou, F \\
\hline $\begin{array}{l}\text { Regression } \\
\text { Error } \\
\text { Total }\end{array}$ & $\begin{array}{r}2 \\
15 \\
17\end{array}$ & $\begin{array}{r}57 \\
97 \\
155\end{array}$ & $\begin{array}{l}95843885 \\
81933892 \\
77777778\end{array}$ & $\begin{array}{r}2897921941 \\
652128926\end{array}$ & & 44 & 00305 \\
\hline Variable & $\begin{array}{c}\text { Paranieter } \\
\text { Estimate }\end{array}$ & & $\begin{array}{r}\text { Standard } \\
\text { Error }\end{array}$ & $\begin{array}{r}\text { Type II } \\
\text { Sum of Squares }\end{array}$ & & $\mathrm{F}$ & Prab $>F$ \\
\hline $\begin{array}{l}\text { INTERCEP } \\
\text { HCMTLNS } \\
\text { NEXELNS }\end{array}$ & $\begin{array}{r}9 \quad 17381289 \\
-0.00801976 \\
0.00890687\end{array}$ & & $\begin{array}{l}27703908 \\
.00891006 \\
.00304451\end{array}$ & $\begin{array}{r}33653082011 \\
528316521 \\
5581473936\end{array}$ & $\begin{array}{r}51 \\
0 \\
8\end{array}$ & $\begin{array}{l}60 \\
81 \\
56\end{array}$ & $\begin{array}{ll}0 & 0001 \\
0 & 3823 \\
0 & 0104\end{array}$ \\
\hline
\end{tabular}

Bounds on condition number 101292. 4051678

Step 3 Variable HCMTLNS Removed R-square $=033814370$

$c(p)=755116459$

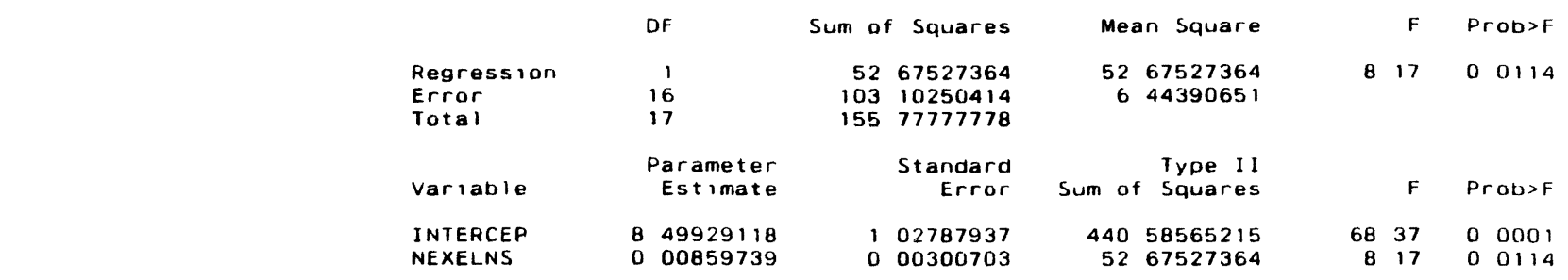

Bounds on condition number 1. 1

All variables left in the model are significant at the 01500 leve

No other variable met the 05000 significance level for entry into the mode 
PERCEIVED COMPLEXITY VS SIZE MEASUREMENTS

Summary of Stepwise Procedure for Dependent Variable 09

Step

Variable

$$
\begin{array}{r}
\text { Number } \\
\text { In }
\end{array}
$$$$
\text { Partial }
$$$$
\text { Mode } 1
$$

$$
0 \quad 3381
$$

03381

NEXELNS

HCMTLNS

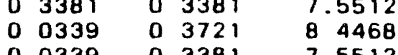

$\begin{array}{ll}8 & 4468 \\ 7 & 5512\end{array}$

$\begin{array}{rl}F & \text { Prob>F } \\ 1744 & 0.0114 \\ 8101 & 03823 \\ 8101 & 03823\end{array}$


PERCEIVED COMPLEXITY VS SIZE MEASUREMENTS

1628 Saturday, May 25, 19913

\begin{tabular}{rcr} 
Obs & \multicolumn{1}{c}{$\begin{array}{c}\text { Dep Var } \\
\text { Q9 }\end{array}$} & $\begin{array}{r}\text { Predict } \\
\text { Value }\end{array}$ \\
1 & 50000 & 89979 \\
2 & 50000 & 91785 \\
3 & 100000 & 122735 \\
4 & 100000 & 124025 \\
5 & 100000 & 123509 \\
6 & 100000 & 100038 \\
7 & 100000 & 105197 \\
8 & 100000 & 93762 \\
9 & 100000 & 93762 \\
10 & 100000 & 94966 \\
11 & 100000 & 91527 \\
12 & 150000 & 114998 \\
13 & 150000 & 97889 \\
14 & 130000 & 12.8066 \\
15 & 130000 & 127722 \\
16 & 140000 & 106486 \\
17 & 16.0000 & 15.3342 \\
18 & 10.0000 & 100210
\end{tabular}

Sta Err Lower95\% Upper95\% Lower95\% Upper95\%
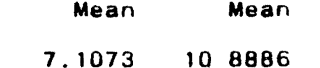

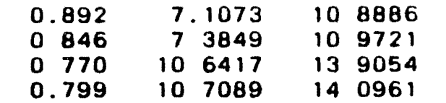

$\begin{array}{llll}0.799 & 107089 & 14096\end{array}$

$\begin{array}{llll}0787 & 106824 & 14 & 0194\end{array}$

$0.674 \quad 85757 \quad 114319$

Predict

Predict

Residual

Std Err

Student
Residual

Cook's

$\begin{array}{llll}799 & 76831 & 110694\end{array}$

$76831 \quad 110694$

$78612 \quad 11 \quad 1320$

$\begin{array}{lrrrr}0 & 852 & 7 & 3455 & 109599\end{array}$

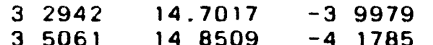

$\begin{array}{ll}3 & 5061 \\ 6 & 6502\end{array}$

67610

$17.8968-2 \quad 2735$

$\begin{array}{llll}7169 & 179850 & -2 & 3509\end{array}$

$4362 \quad 155714-000384$

$7348 \quad 150176 \quad 0 \quad 6238$

$\begin{array}{llll}37348 & 150176 & 0 & 6238\end{array}$

8723

150176

$0 \quad 6238$

$34760 \quad 148294 \quad 0 \quad 8473$

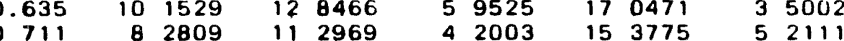

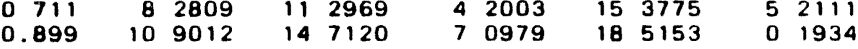

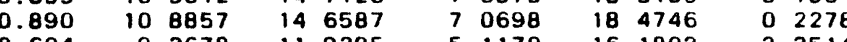

$\begin{array}{llllllll}1.604 & 9.3678 & 11.9295 & 5 & 1170 & 16 & 1803 & 3351\end{array}$

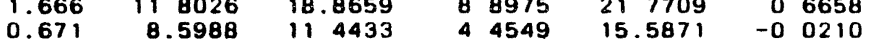

$\begin{array}{ll}2 & 377 \\ 2 & 393 \\ 2 & 419 \\ 2 & 409 \\ 2 & 413 \\ 2 & 447 \\ 2 & 464 \\ 2 & 410 \\ 2 & 410 \\ 2 & 418 \\ 2 & 391 \\ 2 & 458 \\ 2 & 437 \\ 2 & 374 \\ 2.377 \\ 2 & 466 \\ 1 & 915 \\ 2 & 448\end{array}$

\begin{tabular}{ll|}
-1 & 682 \\
-1 & 746
\end{tabular}

$-0940$

$\begin{array}{rr}-0 & 997 \\ -0 & 974\end{array}$

$\begin{array}{rr}-0 & 974 \\ -0 & 002\end{array}$

$\begin{array}{lll}-0 & 002 \\ -0 & 211\end{array}$

$\begin{array}{lll}0 & 259 \\ 0 & 259\end{array}$

0208

$\begin{array}{lll}1 & 354 \\ 1 & 42 & \end{array}$

$2 \quad 139$

0.081

$\begin{array}{ll}0 & 096 \\ 1 & 359\end{array}$

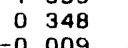

$-2-1-0 \quad 1 \quad 2$

$0 \quad 199$

$\because *$

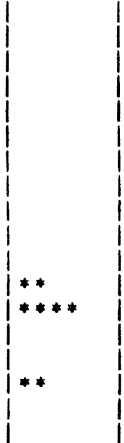

0190

$\begin{array}{ll}0 & 045 \\ 0 & 055\end{array}$

$0 \quad 050$

$\begin{array}{lll}0 & 0 & 00 \\ 0 & 00 & 0 \\ 0 & 0 & 0\end{array}$

0004

0004

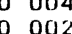

0008

0 068

$\begin{array}{ll}0 & 195 \\ 0 & 0\end{array}$

0000

0001

$\begin{array}{ll}0 & 055 \\ 0 & 046 \\ 0 & 000\end{array}$

Sun of Residuals

Predicted Resid SS (Press)

$103 \quad 1025$

1255567 
The SAS System

Stepwise Procedure for Dependent Variable Q9

Step 1 Variable NCAPN2 Entered R-square $=0.43424720 \quad C(p)=-126424364$

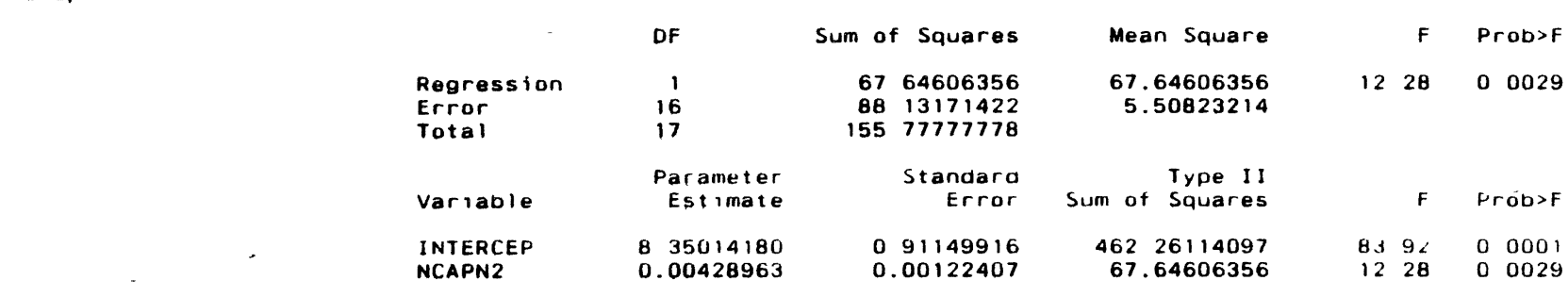

Bounds on condition number. 1.

Step 2 Variable TEFRT Entered

R-square $=-0.53203399 \quad C(p)=-146553862$

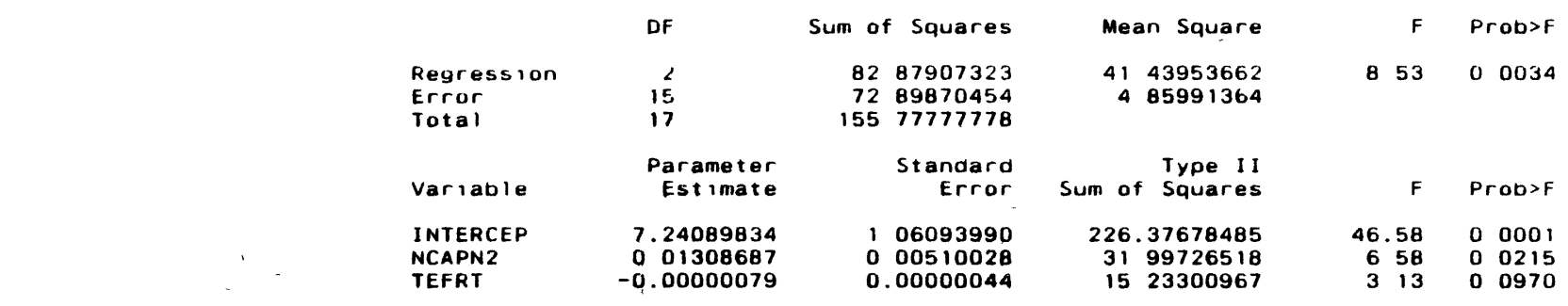

Bounds on condition number

19.67711 .

7870846

Step 3 Variable NCAPN1 Entered R-square $=0.55461989 \quad C(p)=002602637$

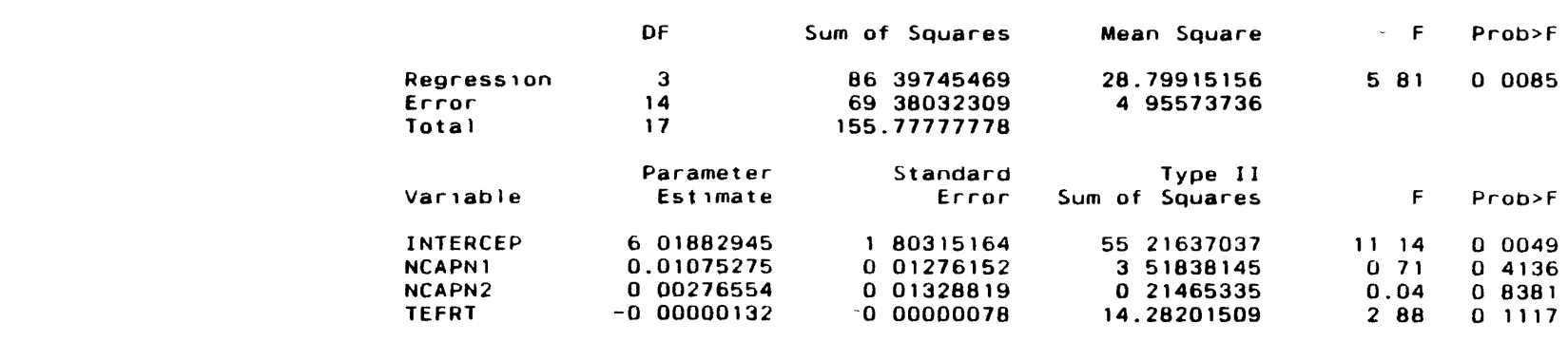

Bounds on condition number

2818324 .

1416923 
Step 4 Variable NCAPN2 Removed R-square $=0.55324195 \quad C(p)=-194295446$

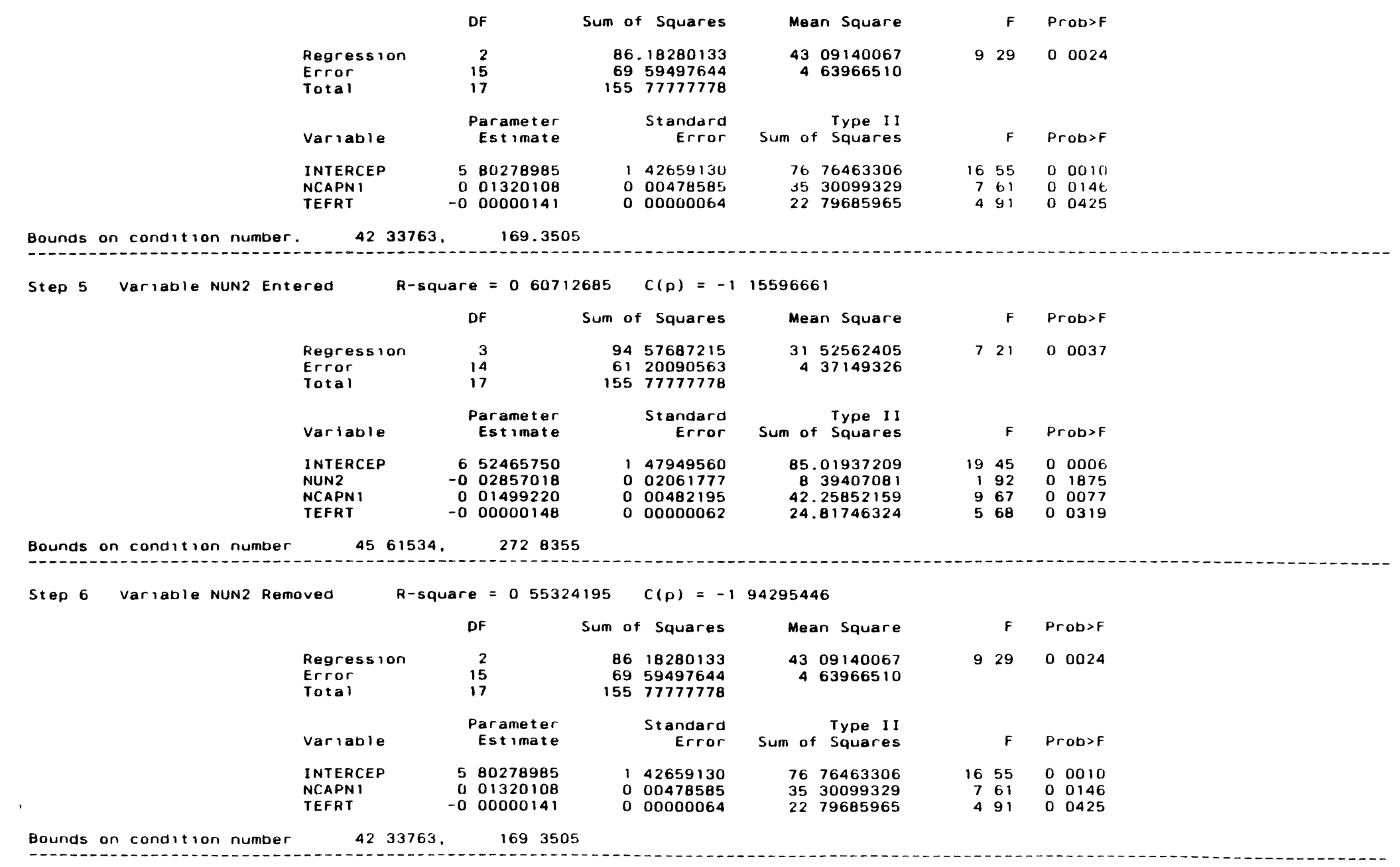

All variables left in the model are significant at the 01500 level

No other variable met the 05000 significance level for entry into the model 
Summary of Stepwise Procedure for Dependent Variable 09

\begin{tabular}{|c|c|c|c|c|c|c|c|c|c|c|}
\hline St & $\begin{array}{l}\text { Variable } \\
\text { Entered }\end{array}$ & Removed & $\begin{array}{r}\text { Number } \\
\text { In }\end{array}$ & $\begin{array}{r}\text { Part } 1 \text { al } \\
R * * 2\end{array}$ & $\begin{array}{r}\text { Mode } 1 \\
R * * 2\end{array}$ & & $c(p)$ & & $\mathbf{F}$ & Prob $>F$ \\
\hline & NCAPI & & 1 & 04342 & $0 \quad 4342$ & -1 & 2642 & 12 & 2809 & $0 \quad 0029$ \\
\hline 2 & TEFRT & & 2 & 00978 & 05320 & -1 & 4655 & 3 & 1344 & 00970 \\
\hline 3 & NCAPN 1 & & 3 & 00226 & 05546 & 0 & 0260 & 0 & 7100 & 04136 \\
\hline 4 & & NCAPN2 & 2 & 00014 & 05532 & -1 & 9430 & 0 & 0433 & 08381 \\
\hline 5 & NUN2 & & 3 & $0 \quad 0539$ & 06071 & -1 & 1560 & 1 & 9202 & $0 \quad 1875$ \\
\hline 6 & & NUN2 & 2 & 00539 & 05532 & -1 & 9430 & 1 & 9202 & $0 \quad 1875$ \\
\hline
\end{tabular}




$\begin{array}{rcr}\text { Obs } & \begin{array}{c}\text { Dep Var } \\ 09\end{array} & \begin{array}{r}\text { Predict } \\ \text { Value }\end{array} \\ 1 & 5.0000 & 7.5421 \\ 2 & 5.0000 & 84736 \\ 3 & 10.0000 & 125446 \\ 4 & 10.0000 & 11.2132 \\ 5 & 100000 & 125081 \\ 6 & 100000 & 84294 \\ 7 & 100000 & 87562 \\ 8 & 100000 & 84889 \\ 9 & 100000 & 92686 \\ 10 & 100000 & 107476 \\ 11 & 100000 & 87900 \\ 12 & 150000 & 13.7175 \\ 13 & 150000 & 110286 \\ 14 & 130000 & 136519 \\ 15 & 130000 & 145753 \\ 16 & 14.0000 & 126316 \\ 17 & 160000 & 135933 \\ 18 & 100000 & 10.0447\end{array}$

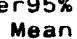

upper $95 \%$

$0942 \quad 55342$

95500

0802108350

$\begin{array}{ll}10 & 1131 \\ 10 & 2058\end{array}$

$1.080 \quad 102058$

$0.847 \quad 66251$

075468816

0 66578515

$0.788 \quad 90675$

$0715 \quad 72659$

$0.864 \quad 118759$

$\begin{array}{lr}0.809 & 9.3039 \\ 0.848 & 118442\end{array}$

$\begin{array}{lll}0.848 & 11 & 8442 \\ 1.044 & 12 & 3448\end{array}$

$1.044 \quad 123448$

$\begin{array}{ll}1.921 & 10.6690 \\ 1509 & 10.3780\end{array}$

16.7957

16.8087

$69.5950^{0}$

Sum of Residuals

Sum of Squared Residuals
1128749
The SAS System

1630 Saturday, May 25, 1991

Sta Err Student
Residual Residual

$\begin{array}{llll}25312 & 125531 & -25421\end{array}$

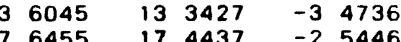

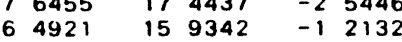

$\begin{array}{llll}7321 & 17.6441 & -2 & 508\end{array}$

$\begin{array}{llll}3 & 4965 & 133623 & 15706\end{array}$

$\begin{array}{llll}36246 & 133531 & 13111\end{array}$

$\begin{array}{lllll}44637 & 140734 & 0 & 7314\end{array}$

$\begin{array}{llll}8587 & 156364 & -07476\end{array}$

$\begin{array}{llll}9525 & 136274 & 1 & 2100 \\ 7708 & 18 & 6642 & 1\end{array}$

$\begin{array}{lll}1242 & 156642 & 1 \\ 6 & 9825\end{array}$

$\begin{array}{llll}87177 & 185861 & -06519\end{array}$

$\begin{array}{llll}4682 & 196723 & -1 & 5703\end{array}$

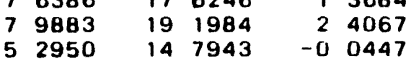

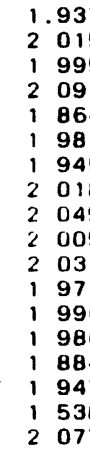

937
015
999
091
864
981
945
018
049
005
032
973
996
980
884
947
538
077

$\begin{array}{rr}-1 & 312 \\ -1 & 724 \\ -1 & 273 \\ -0 & 580 \\ -1 & 346 \\ 0 & 793 \\ 0 & 639 \\ 0 & 749 \\ 0 & 357 \\ -0 & 373 \\ 0 & 596 \\ 0 & 650 \\ 1 & 989 \\ -0 & 329 \\ -0.833 \\ 0.703 \\ 1.565 \\ -0.022\end{array}$

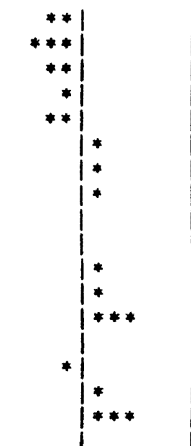

$\begin{array}{lll}0 & 136 \\ 0 & 141\end{array}$

$\begin{array}{ll}0 & 141 \\ 0 & 087\end{array}$

$\begin{array}{ll}0 & 007\end{array}$

0
0

$\begin{array}{lll}0 & 038 \\ 0 & 031 & -1\end{array}$

0026

c) 0014

0 ou

$0 \quad 015$

$\begin{array}{ll}0 & 027 \\ 0 & 217\end{array}$

$\begin{array}{ll}0 & 007\end{array}$

$\begin{array}{lll}0 & 071 \\ 0 & 037\end{array}$

$\begin{array}{ll}0 & 037 \\ 0 & 786\end{array}$

0000 
The SAS System

Stepwise Procedure for Dependent Variable $Q 9$

Step 1 Variable NODEVG Entered R-square $=042839393 \quad C(p)=217330924$

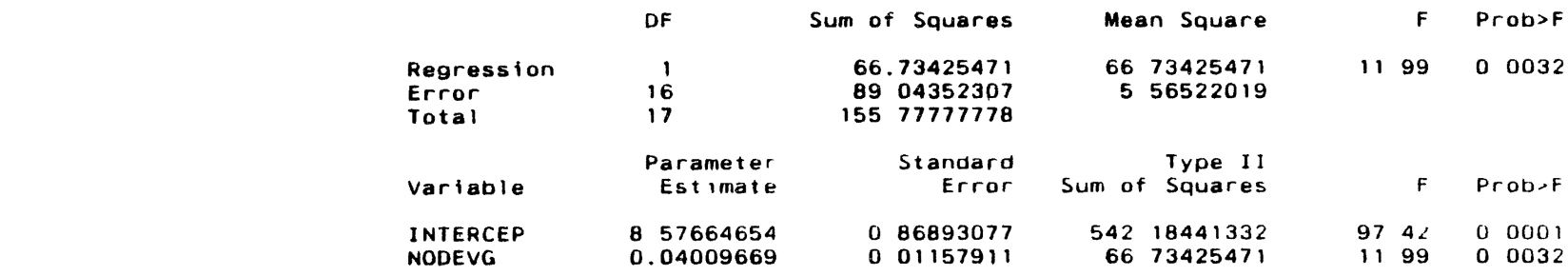

Bounds on condition number 1. 1

Step 2 Variable HOSTVG Entered R-square $=046986168$

$C(p)=300000000$

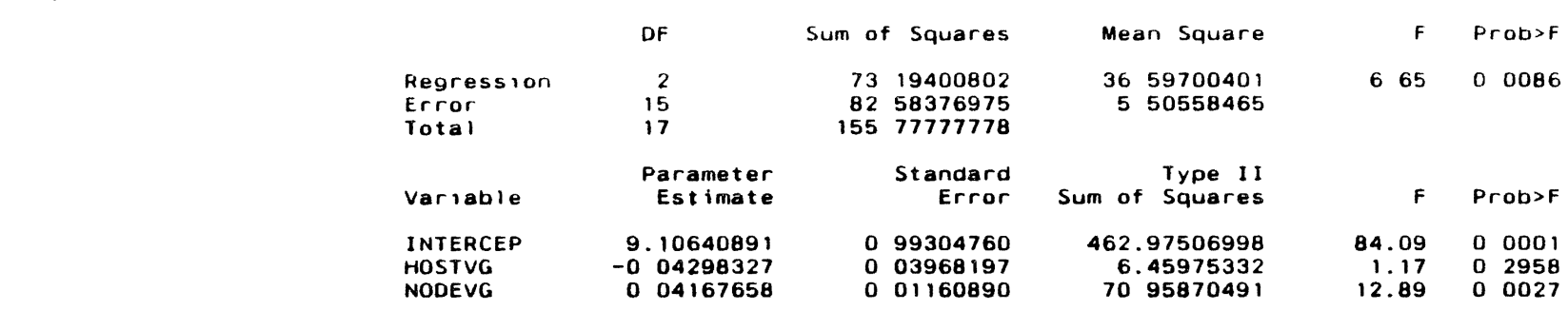

Bounds on condition number

1016039 ,

4064155

Step 3 Variable HOSTVG Removed R-square $=042839393$

$C(p)=2.17330924$

\begin{tabular}{|c|c|c|c|c|c|c|}
\hline & DF & Sum of & f Squares & Mean Square & $F$ & Prob>F \\
\hline $\begin{array}{l}\text { Regression } \\
\text { Error } \\
\text { Total }\end{array}$ & $\begin{array}{r}1 \\
16 \\
17\end{array}$ & $\begin{array}{r}66 \\
89 \\
155\end{array}$ & $\begin{array}{l}73425471 \\
04352307 \\
77777778\end{array}$ & $\begin{array}{r}6673425471 \\
5 \quad 56522019\end{array}$ & 1199 & $0 \quad 0032$ \\
\hline Variable & $\begin{array}{l}\text { Parameter } \\
\text { Estimate }\end{array}$ & & $\begin{array}{l}\text { Stạndard } \\
\text { Error }\end{array}$ & $\begin{array}{r}\text { Type II } \\
\text { Sum of Squares }\end{array}$ & $\mathbf{F}$ & Prob $>F$ \\
\hline $\begin{array}{l}\text { INTERCEP } \\
\text { NODEVG }\end{array}$ & $\begin{array}{ll}8 & 57664654 \\
0 & 04009669\end{array}$ & $\begin{array}{l}0 \\
0\end{array}$ & $\begin{array}{l}86893077 \\
01157911\end{array}$ & $\begin{array}{rr}542 & 18441332 \\
66 & 73425471\end{array}$ & $\begin{array}{l}9742 \\
11.99\end{array}$ & $\begin{array}{ll}0 & 0001 \\
0 & 0032\end{array}$ \\
\hline
\end{tabular}

Bounds on condition number 1

All variables left in the model are significant at the 01500 level

No other variable met the 05000 significance level for entry into the model 
The SAS System

1631 Saturday, May 25, 1991

Summary of Stepwise Procedure for Dependent Variable Q9

Step

Variable

$$
\text { Number Partial Model }
$$

$R * * 2$ R**2

$c(p)$

NODEVG

$\begin{array}{llllll}0 & 4284 & 0 & 4284 & 2 & 1733\end{array}$

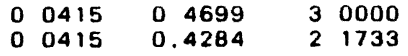

F Prob>F

2 HOSTVG

HOSTVG

$\begin{array}{rrrr}11 & 9913 & 0 & 0032 \\ 1 & 1733 & 0 & 2958 \\ 1 & 1733 & 0 & 2958\end{array}$ 


\begin{tabular}{|c|c|c|}
\hline Ods & $\begin{array}{c}\text { Dep } \\
Q 9\end{array}$ & $\begin{array}{r}\text { Predict } \\
\text { value }\end{array}$ \\
\hline 1 & 50000 & 8.8172 \\
\hline 2 & 50000 & 90578 \\
\hline 3 & 100000 & 111829 \\
\hline 4 & 100000 & 11.0626 \\
\hline 5 & 100000 & 12.8670 \\
\hline 6 & 100000 & 97795 \\
\hline 7 & 100000 & $10 \quad 1805$ \\
\hline 8 & 100000 & 92583 \\
\hline & 100000 & 92583 \\
\hline 10 & 100000 & 95791 \\
\hline 11 & 100000 & $9 \quad 1781$ \\
\hline 12 & 150000 & 141100 \\
\hline 13 & 150000 & 9.7395 \\
\hline 14 & 13.0000 & 13.6689 \\
\hline 15 & 130000 & 136689 \\
\hline 16 & 140000 & 102607 \\
\hline 17 & 16.0000 & 146713 \\
\hline 18 & 10.0000 & 9.6593 \\
\hline
\end{tabular}

Sum of Residuals

Sum of Squared Residuals
Std Err Lower95\% Upper95\% Lower95\% Upper95\%
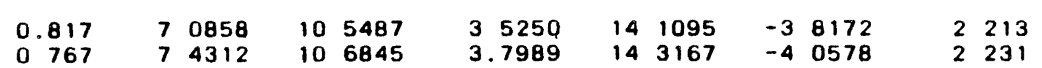

0.817

74312

106845

35250
3.7989

56299905 123753

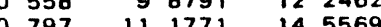

$0642 \quad 84192 \quad 11.1399$

$0592 \quad 89245 \quad 114365$

$\begin{array}{llll}0.729 & 77137 & 108029\end{array}$

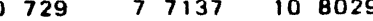

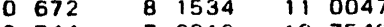

$\begin{array}{rrrrr}0744 & 76013 & 107549 \\ 1.084 & 118126 & 16 & 4073\end{array}$

$\begin{array}{rrrr}1.084 & 118126 & 16 & 4073 \\ 0.648 & 8.3666 & 11 & 1123\end{array}$

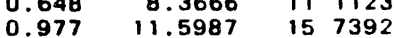

$0.977 \quad 115987 \quad 157392$

$\begin{array}{llll}0.585 & 9 & 0208 & 11.5006\end{array}$

$\begin{array}{rrrr}1226 & 120730 & 172697 \\ 0660 & 8.2607 & 11 & 0579\end{array}$

\subsection{5}

89.0435
1094661 $163167-40578$

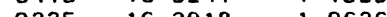
$45968 \quad 149623 \quad 02205$ $\begin{array}{llllll}5 & 0242 & 15 & 3368 & -0 & 1805\end{array}$ $40242144924 \quad 07417$ $440242 \quad 144924 \quad 07417$

. 934401442180.8219

4.55350 .14 .9254000

$82564 \quad 19.0815-0.6689$

$190815-0.6689$

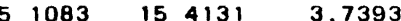

$\begin{array}{llll}9 & 0356 & 203070 & 13287 \\ 4 & 4664 & 14.8521 & 0.3407\end{array}$

$\begin{array}{ll}2 & 231 \\ 2 & 291 \\ 2 & 292 \\ 2 & 220 \\ 2 & 270 \\ 2 & 283 \\ 2 & 244 \\ 2 & 244 \\ 2 & 261 \\ 2 & 239 \\ 2 & 095 \\ 2 & 268 \\ 2 & 147 \\ 2 & 147 \\ 2 & 285 \\ 2 & 016 \\ 2 & 265\end{array}$
The SAS System

1631 Saturday, May 25, 19913

$75882 \quad 181458-28670$

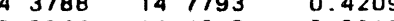

$\begin{array}{lll}-1 & 725 \\ -1 & 819\end{array}$

$\begin{array}{lll}-1 & 8 & 19 \\ -0 & 5 & 16\end{array}$

$\begin{array}{lll}-0 & 464 \\ -1 & 29 & 1\end{array}$

\begin{tabular}{rr|r|}
-1 & 291 \\
0 & 097
\end{tabular}

$\begin{array}{rrr}-1 & 291 \\ -0 & 0979\end{array}$

$\begin{array}{lll}0 & 331 \\ 0 & 331\end{array}$

$0 \quad 186$

$\begin{array}{lll}0 & 367 \\ 0 & 465\end{array}$

$\begin{array}{rrr}0 & 425 \\ 2 & 319\end{array}$

$\begin{array}{lll}-0 & 311 \\ -0 & 311 \\ 1 & 6 & 636\end{array}$

$\begin{array}{rr}-0 & 311 \\ 1 & 636\end{array}$

$\begin{array}{ll}1 & 636 \\ 0 & 659 \\ 0 & 150\end{array}$

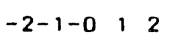

Cook 5

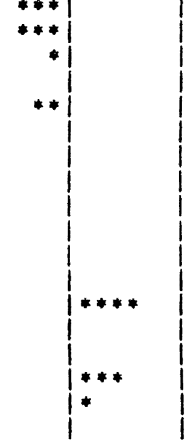

$\begin{array}{ll}0 & 203 \\ 0 & 196\end{array}$

$0 \quad 008$

$\begin{array}{lll}0 & 006 \\ 0 & 107\end{array}$

0000

0000

0006

0006

0002

0007

$\begin{array}{ll}0 & 024 \\ 0 & 219\end{array}$

$\begin{array}{lll}0 & 0 & 10 \\ 0 & 010\end{array}$

0.088 0080 
Stepwise Procedure for Dependent Variable Q9

Step 1 Variable NMSGSND Entered R-square $=0.33152328 \quad C(p)=0.98429269$

\begin{tabular}{|c|c|c|c|c|c|}
\hline & DF & Sum of Squares & Mean Square & $\mathrm{F}$ & Prob $>F$ \\
\hline $\begin{array}{l}\text { Regression } \\
\text { Error } \\
\text { Total }\end{array}$ & $\begin{array}{r}1 \\
16 \\
17\end{array}$ & $\begin{array}{r}51.64396035 \\
104.13381743 \\
1557777778\end{array}$ & $\begin{array}{r}51.64396035 \\
650836359\end{array}$ & 7.94 & 00124 \\
\hline Variable & $\begin{array}{r}\text { Parameter } \\
\text { Estimate }\end{array}$ & $\begin{array}{r}\text { Standard } \\
\text { Error }\end{array}$ & $\begin{array}{r}\text { Type II } \\
\text { Sum of Squares }\end{array}$ & $\mathrm{F}$ & Prob $>F$ \\
\hline $\begin{array}{l}\text { INTERCEP } \\
\text { NMSGSND }\end{array}$ & $\begin{array}{l}\text { B } 55601660 \\
\text { 0.26244813 }\end{array}$ & $\begin{array}{l}102344210 \\
0.09316861\end{array}$ & $\begin{array}{r}45487124703 \\
5164396035\end{array}$ & $\begin{array}{rl}69 & 89 \\
7 & 94\end{array}$ & $\begin{array}{lll}0 & 0001 \\
0 & 0 & 124\end{array}$ \\
\hline
\end{tabular}

Bounds on condition number. 1.

1

Step 2 Variable HMSGREC Entered R-square $=037274166 \quad C(p)=206035888$

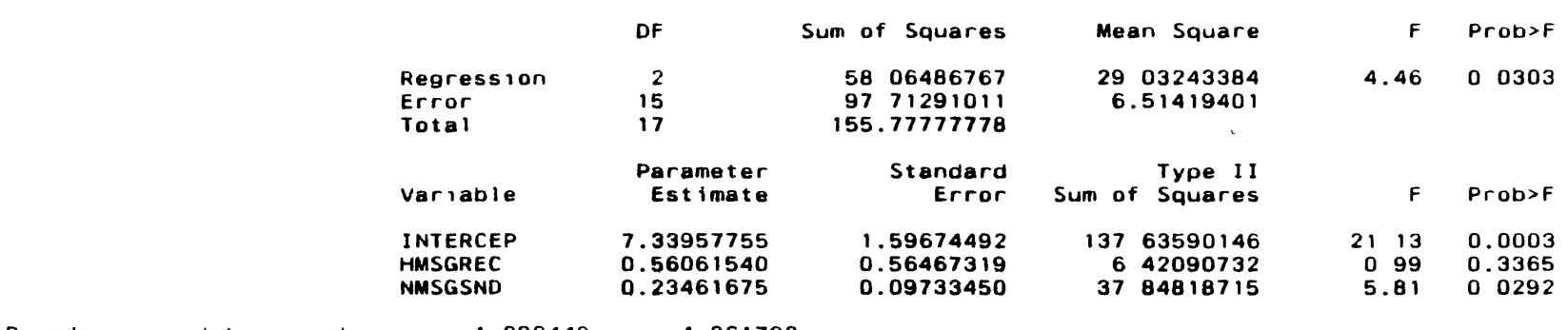

Bounds on condition number 1090449

4361798

Step 3 Variable HMSGREC Removed R-square $=0.33152328$

$C(p)=0.98429269$

$\begin{array}{ll}\text { Regression } & \text { DF } \\ \text { Error } & 1 \\ \text { Total } & 16 \\ & 17 \\ \text { Variable } & \text { Parameter } \\ \text { INTERCEP } & 855601660 \\ \text { NMSGSND } & 026244813\end{array}$

1.

\begin{tabular}{|c|c|c|c|c|}
\hline Sum of & f Squares & Mean Square & $\mathbf{F}$ & Prob $>F$ \\
\hline $\begin{array}{r}51 \\
104 \\
155\end{array}$ & $\begin{array}{l}64396035 \\
13381743 \\
77777778\end{array}$ & $\begin{array}{r}5164396035 \\
6.50836359\end{array}$ & 794 & 00124 \\
\hline & $\begin{array}{r}\text { Standard } \\
\text { Error }\end{array}$ & Sum of $\begin{array}{l}\text { Type II } \\
\text { Squares }\end{array}$ & $\mathbf{F}$ & Prob>F \\
\hline $\begin{array}{l}1 \\
0\end{array}$ & $\begin{array}{l}02344210 \\
09316861\end{array}$ & $\begin{array}{r}454.87124703 \\
5164396035\end{array}$ & $\begin{array}{r}6989 \\
7.94\end{array}$ & $\begin{array}{ll}0 & 0001 \\
0 & 0124\end{array}$ \\
\hline
\end{tabular}

Bounds on condition number

All variables left in the model are significant at the 01500 level

No other variable met the 05000 significance level for entry into the mode 
The SAS System

Summary of Stepwise Procedure for Dependent Variable Q9 Variable Entered Removed Number NMSGSND

HMSGREC HMSGREC

Partial Mode

$R * 2$

$c(p)$

$\begin{array}{llllll}1 & 0 & 3315 & 0 & 3315 & 0.9843\end{array}$
1631 Saturday, May 25, 1991,

F Prob>F

7935000124

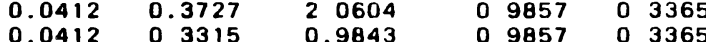


The SAS System

$\begin{array}{rcr}\text { Obs } & \begin{array}{c}\text { Dep Var } \\ 09\end{array} & \begin{array}{r}\text { Predict } \\ \text { Value }\end{array} \\ 1 & 50000 & 9.6058 \\ 1 & 5 & 9.000 \\ 2 & 5.0000 & 93434 \\ 3 & 10.0000 & 90809 \\ 4 & 100000 & 111805 \\ 5 & 100000 & 111805 \\ 6 & 100000 & 109180 \\ 7 & 100000 & 109180 \\ 8 & 100000 & 103932 \\ 9 & 10.0000 & 10.3932 \\ 10 & 100000 & 111805 \\ 11 & 100000 & 98683 \\ 12 & 150000 & 111805 \\ 13 & 150000 & 93434 \\ 14 & 130000 & 117054 \\ 15 & 130000 & 11449 \\ 16 & 14.0000 & 117054 \\ 17 & 160000 & 169544 \\ 18 & 10.0000 & 96058\end{array}$

Sum of Residuals

Sum of Squared Residuals Predict

$$
\text { Mean }
$$$$
\text { Mean }
$$

Lower95\% Upper95\%

$\begin{array}{lll}754 & 8.0067 \quad 11.2050\end{array}$

0.814

0879

0.610

8.0067
76178
72165

110690

$\begin{array}{lll}2165 & 109454\end{array}$

$8870 \quad 124740$

$\begin{array}{llll}601 & 96431 & 12 & 1930\end{array}$

$\begin{array}{lllll}0.601 & 96431 & 12 & 1930 \\ 0.627 & 9 & 0650 & 11 & 7213\end{array}$

0.627

$610 \quad 98870 \quad 124740$
0

$\begin{array}{llll}8 & 3800 & 113565\end{array}$

$610 \quad 98870 \quad 124740$

$\begin{array}{llll}814 & 76178 & 110690\end{array}$

$\begin{array}{lll}633 & 0.1018 & 127841\end{array}$

$\begin{array}{llll}.236 & 122903 & 13 & 1205 \\ 0.754 & 8.0067 & 216936\end{array}$

$\begin{array}{lll}0.754 & 80067 & 11.2050\end{array}$

\begin{abstract}
0
\end{abstract}
Std Err Lower95\% Upper95\%

$\begin{array}{ll}104 & 1338 \\ 140 & 8333\end{array}$ $\begin{array}{llll}668 & 10.2903 & 13 & 1205\end{array}$

1631 Saturday, May 25, 19913

Std Err Student

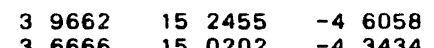

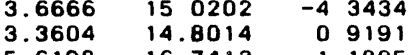

$5.6198 \quad 167412 \quad-11805$

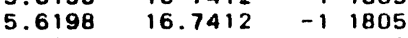

$53616 \quad 16.4745 \quad-09180$

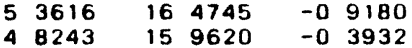

$\begin{array}{llll}4.8243 & 159620 & -03932\end{array}$

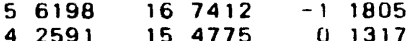

$56198 \quad 167412 \quad 31317$

$\begin{array}{llll}36666 & 150202 & 56195 \\ 6 & 1502 & 566\end{array}$

$\begin{array}{llll}6 & 1152 & 17.2956 & 12946\end{array}$

$\begin{array}{llll}58710 & 17.0149 & 15571\end{array}$

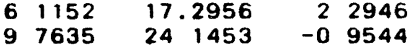

$\begin{array}{rrr}9.7635 & 24.1453 & -0.9544 \\ 3.9662 & 15.2455 & 0.3942\end{array}$
2437
-14

$0 \quad 162$

0.171

.180

007

004

001

072

010

001

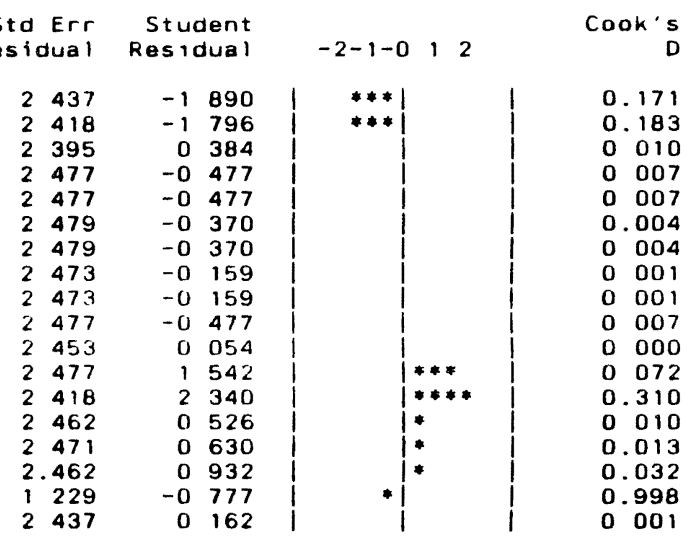

Cook's 
Stepwise Procedure for Dependent Variabie Q9

\begin{tabular}{|c|c|c|c|c|c|c|c|}
\hline & & & DF & Sum of Squares & Mean Square & $\mathbf{F}$ & Prob>F \\
\hline & & $\begin{array}{l}\text { Regression } \\
\text { Error } \\
\text { Total }\end{array}$ & $\begin{array}{r}1 \\
16 \\
17\end{array}$ & $\begin{array}{r}5362598723 \\
102.15179055 \\
155.77777778\end{array}$ & $\begin{array}{r}53 \quad 62598723 \\
6 \quad 38448691\end{array}$ & 840 & $0 \quad 0105$ \\
\hline & & Variable & $\begin{array}{l}\text { Parameter } \\
\text { Estimate }\end{array}$ & $\begin{array}{l}\text { Standard } \\
\text { Error }\end{array}$ & 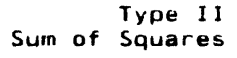 & $\mathbf{F}$ & Prob $>F$ \\
\hline & & $\begin{array}{l}\text { INTERCEP } \\
\text { R2T }\end{array}$ & $\begin{array}{l}8.43771930 \\
0.00011275\end{array}$ & $\begin{array}{ll}1 & 03441233 \\
0 & 00003890\end{array}$ & $\begin{array}{r}42480417165 \\
53.62598723\end{array}$ & $\begin{array}{rl}66 & 54 \\
8 & 40\end{array}$ & $\begin{array}{ll}0 & 0001 \\
0 & 0105\end{array}$ \\
\hline
\end{tabular}

Bounds on condition number:

1.

Step 2 Variable RIU Entered R-square $=0.48454134 \quad C(p)=338292532$

\begin{tabular}{|c|c|c|c|c|c|}
\hline & DF & Sum of Squares & Mean Square & $\mathbf{F}$ & Prob>F \\
\hline $\begin{array}{l}\text { Regression } \\
\text { Error } \\
\text { Total }\end{array}$ & $\begin{array}{r}2 \\
15 \\
17\end{array}$ & $\begin{array}{r}7548077246 \\
80.29700532 \\
155.77777778\end{array}$ & $\begin{array}{r}3774038623 \\
5.35313369\end{array}$ & 7.05 & $0 \quad 0069$ \\
\hline Variable & $\begin{array}{l}\text { Parameter } \\
\text { Estimate }\end{array}$ & $\begin{array}{r}\text { Standard } \\
\text { Error }\end{array}$ & Sum of $\begin{array}{l}\text { Type II } \\
\text { Squares }\end{array}$ & $\mathbf{F}$ & Prob $>F$ \\
\hline $\begin{array}{l}\text { INTERCEP } \\
\text { R1U } \\
\text { R2T }\end{array}$ & $\begin{array}{r}9.82834273 \\
-0.00206541 \\
0.00017636\end{array}$ & $\begin{array}{r}1 \quad 17082632 \\
000102220 \\
0.00004754\end{array}$ & $\begin{array}{r}377.21045288 \\
21.85478523 \\
73.66705577\end{array}$ & $\begin{array}{rl}70 & 47 \\
4 & 08 \\
13 & 76\end{array}$ & $\begin{array}{ll}0 & 0001 \\
0 & 0616 \\
0 & 0021\end{array}$ \\
\hline
\end{tabular}

Bounds on condition number.

1.781157 .

7.124629

Step 3 Variable RJT Entered R-square $=0.59054829 \quad C(p)=2.21934082$

\begin{tabular}{|c|c|c|c|c|c|}
\hline & DF & Sum of Squares & Mean Square & $\mathbf{F}$ & Prob $>F$ \\
\hline $\begin{array}{l}\text { Regression } \\
\text { Error } \\
\text { Total }\end{array}$ & $\begin{array}{r}3 \\
14 \\
17\end{array}$ & $\begin{array}{r}91.99430002 \\
63.7834776 \\
155.77777778\end{array}$ & $\begin{array}{r}30.66476667 \\
4.55596270\end{array}$ & 6.73 & 0.0049 \\
\hline Variable & $\begin{array}{l}\text { Parameter } \\
\text { Estimate }\end{array}$ & $\begin{array}{r}\text { Standard } \\
\text { Error }\end{array}$ & $\begin{array}{r}\text { Type II } \\
\text { Sum of Squares }\end{array}$ & $\mathbf{F}$ & Prob>F \\
\hline $\begin{array}{l}\text { INTERCEP } \\
\text { RIU } \\
\text { R2T } \\
\text { R3T }\end{array}$ & $\begin{array}{r}650429403 \\
-000250758 \\
0.01513110 \\
-001624706\end{array}$ & $\begin{array}{l}2.05307476 \\
0.00097120 \\
0.00785518 \\
0.00853385\end{array}$ & 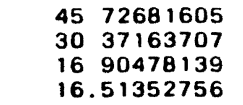 & $\begin{array}{rl}10.04 \\
6 & 67 \\
3 & 71 \\
3 & 62\end{array}$ & $\begin{array}{ll}0 & 0068 \\
0 & 0217 \\
0.0746 \\
0 & 0777\end{array}$ \\
\hline
\end{tabular}

Bounds on condition number

571359

3425069 


\begin{tabular}{|c|c|c|c|c|c|}
\hline & $\mathrm{DF}$ & Sum of Squares & Mean Square & $F$ & Prob $>F$ \\
\hline $\begin{array}{l}\text { Regression } \\
\text { Error } \\
\text { Total }\end{array}$ & $\begin{array}{r}4 \\
13 \\
17\end{array}$ & $\begin{array}{r}9792490391 \\
5785287387 \\
155.77777778\end{array}$ & $\begin{array}{r}24 \quad 48122598 \\
4 \quad 45022107\end{array}$ & 550 & 00081 \\
\hline Variable & $\begin{array}{r}\text { Parameter } \\
\text { Estimate }\end{array}$ & $\begin{array}{r}\text { Standard } \\
\text { Error }\end{array}$ & 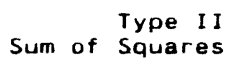 & $\mathrm{F}$ & Prob $>F$ \\
\hline $\begin{array}{l}\text { INTERCEP } \\
\text { RIU } \\
\text { RIT } \\
\text { R2T } \\
\text { R3T }\end{array}$ & $\begin{array}{rl}5 & 31019342 \\
-0 & 00126333 \\
-0 & 00210321 \\
0 & 02135799 \\
-0 & 02085151\end{array}$ & $\begin{array}{ll}2 & 27755082 \\
0 & 00144328 \\
0 & 00182190 \\
0 & 00945342 \\
0 & 00932980\end{array}$ & $\begin{array}{rl}24 & 19168466 \\
3 & 40967621 \\
5 & 93060389 \\
22 & 71562703 \\
22 & 22860275\end{array}$ & $\begin{array}{ll}5 & 44 \\
0 & 77 \\
1 & 33 \\
5 & 10 \\
4 & 99\end{array}$ & $\begin{array}{ll}0 & 0365 \\
0 & 3973 \\
0 & 2691 \\
0 & 0417 \\
0 & 0436\end{array}$ \\
\hline
\end{tabular}

Bounds on condition number 8471759 .

629776

Step 5 Variable RIU Removed R-square $=060673113 \quad C(p)=1.73639327$

\begin{tabular}{|c|c|c|c|c|c|}
\hline & DF & Sum of Squares & Mean Square & $\mathbf{F}$ & Prob $>F$ \\
\hline $\begin{array}{l}\text { Regression } \\
\text { Error } \\
\text { Total }\end{array}$ & $\begin{array}{r}3 \\
14 \\
17\end{array}$ & $\begin{array}{r}9451522771 \\
61 \\
155255007 \\
155.77777778\end{array}$ & $\begin{array}{r}31.50507590 \\
4 \quad 37589643\end{array}$ & 7.20 & $0 \quad 0037$ \\
\hline Variable & $\begin{array}{l}\text { Parameter } \\
\text { Estimate }\end{array}$ & $\begin{array}{r}\text { Standara } \\
\text { Error }\end{array}$ & $\begin{array}{l}\text { Type II } \\
\text { Sum of Squares }\end{array}$ & $\mathbf{F}$ & Prob $>F$ \\
\hline $\begin{array}{l}\text { INTERCEP } \\
\text { R1T } \\
\text { R2T } \\
\text { R3T }\end{array}$ & 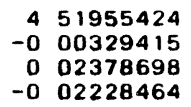 & $\begin{array}{r}207324682 \\
000120151 \\
0.008961118 \\
000910799\end{array}$ & $\begin{array}{r}20.79487058 \\
32.89256475 \\
30.83299237 \\
26 \quad 19587066\end{array}$ & $\begin{array}{ll}4 & 75 \\
7 & 52 \\
7 & 05 \\
5 & 99\end{array}$ & 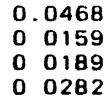 \\
\hline
\end{tabular}

Bounds on condition number.

7741773.

4390594

All variables left in the model are significant at the 01500 level

No other variable met the 05000 significance level for entry into the model

Summary of Stepwise Procedure for Dependent Variable 09

\begin{tabular}{|c|c|c|c|c|c|c|c|}
\hline tep & $\begin{array}{l}\text { Variable } \\
\text { Entered Removed }\end{array}$ & $\begin{array}{r}\text { Number } \\
\text { In }\end{array}$ & $\begin{array}{r}\text { Partial } \\
R * * 2\end{array}$ & $\begin{array}{r}\text { Model } \\
R * * 2\end{array}$ &,$C(p)$ & $\mathrm{F}$ & Prob $>F$ \\
\hline & R2T & 1 & 034 & 0.3 & 55 & B 3994 & 0 \\
\hline & RIU & 2 & & & 338 & & 0.0616 \\
\hline 3 & R3T & 3 & $0 \quad 1060$ & 0.5905 & 2193 & 3.6246 & 00777 \\
\hline 4 & RIT & 4 & 00381 & 0.62 & 3.0832 & 13327 & 02691 \\
\hline 5 & RIU & 3 & $0 \quad 0219$ & 06067 & 17364 & 0.7662 & 0 3973 \\
\hline
\end{tabular}




$\begin{array}{rcr}\text { Obs } & \begin{array}{c}\text { Dep Var } \\ \text { Q9 }\end{array} & \begin{array}{r}\text { Predict } \\ \text { Value }\end{array} \\ 1 & 50000 & 72680 \\ 2 & 50000 & 80226 \\ 2 & 5000 & 12.3061 \\ 3 & 100000 & 106364 \\ 4 & 100000 & 100 \\ 5 & 100000 & 97871 \\ 6 & 100000 & 100509 \\ 7 & 100000 & 105974 \\ 8 & 10.0000 & 86940 \\ 9 & 100000 & 93175 \\ 10 & 100000 & 90790 \\ 11 & 100000 & 84511 \\ 12 & 15.0000 & 135770 \\ 13 & 150000 & 106852 \\ 14 & 130000 & 148496 \\ 15 & 13.0000 & 14.9086 \\ 16 & 140000 & 12.2032 \\ 17 & 16.0000 & 142987 \\ 18 & 100000 & 11.2677\end{array}$

Sum of Residuals

Sum of Squared Residuals
Predicted Resid SS (Press)
Std Err Lower95\% Upper95\%

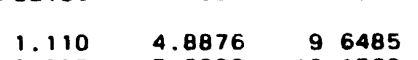

$58883 \quad 101569$

700

0.958

1.771

0.5823

38076

126905

$\begin{array}{lll}0.674 & 86062 & 114955\end{array}$

$0.74670938 \quad 10.2943$

$0.66378965 \quad 107386$

$\begin{array}{lll}0662 & 76584 & 104997\end{array}$

.784

0.784

$\begin{array}{ll}10 & 4997 \\ 10 & 1329\end{array}$

1001329

$9.1740 \quad 121963$

$\begin{array}{lll}0.7059 & 12.6579 \quad 17.1593\end{array}$

$0.810 \quad 10.4659 \quad 13.9405$

$\begin{array}{lll}0.810 & 10.4659 & 13.9405 \\ 1.668 & 107208 & 178766 \\ 0.865 & 94117 & 131237\end{array}$

0.865

$\begin{array}{lll}3 & 1237\end{array}$

$\begin{array}{rr}61 & 2626 \\ 108 & 2328\end{array}$
Lower95\% Upper95

Residual Residual Residual

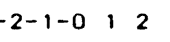

Cook's

$\begin{array}{lll}2.1890 & 12.3470 & -2.2680 \\ 3.0542 & 129909 & -30226\end{array}$

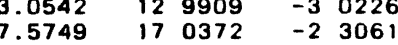

$\begin{array}{llll}57019 & 155709 & -0 & 6364\end{array}$

$53374 \quad 14.7643-02129$

$57119 \quad 15.4828 \quad-05974$

$\begin{array}{lll}39306 & 134575 & 13060\end{array}$

$\begin{array}{llll}46113 & 140238 & 0 & 6825 \\ 4 & 029 & 13 & \end{array}$

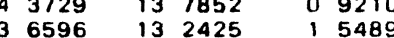

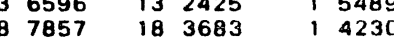

$\begin{array}{lll}5.9509 & 154194 \quad 43148\end{array}$

$9.8672 \quad 19.9281-1.8496$

$7.3920 \quad 170144 \quad 17968$

$\begin{array}{lll}8.5601 & 20.0372 & 1968\end{array}$

8.5601
6.4124

$\begin{array}{rrr}16.0372 & 1 & 7013 \\ 16.1230 & -1 & 2677\end{array}$

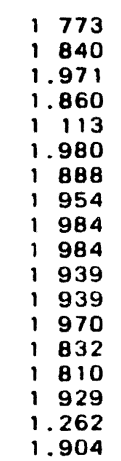

$\begin{array}{ll}-1 & 279 \\ -1 & 643\end{array}$

$\begin{array}{ll}-1 & 643 \\ -1 & 170\end{array}$

$\begin{array}{rrr}-0 & 342 \\ 0 & 191\end{array}$

$\begin{array}{rr}0 & 191 \\ -0 & 026\end{array}$

$\begin{array}{ll}-0 & 026 \\ -0 & 316\end{array}$

$\begin{array}{lll}0 & 668 \\ 0 & 344 \\ 0 & 4 & -16\end{array}$

$\begin{array}{ll}0 & 344 \\ 0 & 464 \\ 0 & 799\end{array}$

$\begin{array}{lll}0 & 799 \\ 0 & 734\end{array}$

2191

$-1.010$

$\begin{array}{rr}-1 & 055 \\ 0 & 932\end{array}$

$\begin{array}{ll}0 & 932 \\ 1 & 348 \\ -0 & 666\end{array}$

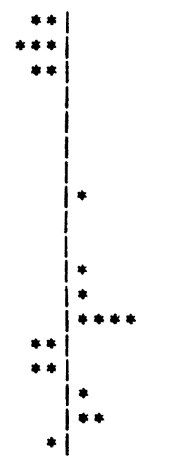

$\begin{array}{ll}0 & 160 \\ 0 & 197\end{array}$

$0 \quad 043$

$\begin{array}{lll}0 & 008 \\ 0 & 023 & 0\end{array}$

$\begin{array}{lll}0 & 023 \\ 0 & 000 & 0\end{array}$

0006

0016

0003

0006

$\begin{array}{ll}0 & 026 \\ 0 & 022\end{array}$

0.154

0.094

$\begin{array}{ll}0 & 094 \\ 0 & 038\end{array}$

0.793
0.023 
Stepwise Procedure for Dependent Variable Q9 Step 1 Variable TCAPN2 Entered R-square $=0.37964848 \quad C(p)=$

\begin{tabular}{|c|c|c|c|c|c|c|}
\hline & DF & Sum of Squares & Mean Square & & $\mathrm{F}$ & Prob $>F$ \\
\hline $\begin{array}{l}\text { Regression } \\
\text { Error } \\
\text { Total }\end{array}$ & $\begin{array}{r}1 \\
16 \\
17\end{array}$ & $\begin{array}{r}59.14079716 \\
96 \quad 63698061 \\
15577777778\end{array}$ & $\begin{array}{rl}59 & 14079716 \\
6 & 03981129\end{array}$ & 9 & 79 & 00065 \\
\hline Varigole & $\begin{array}{l}\text { Parameter } \\
\text { Estimate }\end{array}$ & $\begin{array}{r}\text { Standard } \\
\text { Error }\end{array}$ & $\begin{array}{r}\text { Type II } \\
\text { Sum of Squares }\end{array}$ & & $\mathrm{F}$ & Prob $>F$ \\
\hline $\begin{array}{l}\text { INTERCEP } \\
\text { TCAPN2 }\end{array}$ & $\begin{array}{ll}8 & 04128646 \\
0 & 00364791\end{array}$ & $\begin{array}{ll}1 & 07873453 \\
0 & 00116577\end{array}$ & $\begin{array}{r}33561802446 \\
59.14079716\end{array}$ & $\begin{array}{r}55 \\
9\end{array}$ & $\begin{array}{l}57 \\
79\end{array}$ & $\begin{array}{ll}0 & 0001 \\
0 & 0065\end{array}$ \\
\hline
\end{tabular}

Bounds on condition number. 1. 1

Step 2 Vartable RIT Entered R-square $=0.54426289 \quad C(p)=$

Sum of Squares

Mean Square $F \quad$ Prob>F

Regression
Error

15

Total

84.78406343

70.99371435

55.77777778

Parameter
Variable Estimate

INTERCEP

TCAPN2

Estimate

RIT

6.41259601

0.03006499
-0.00089120

896

4.73291429

0028

Error Sum of Type II

1.18383402

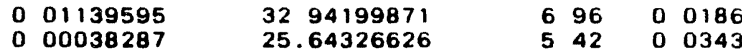

F Prob>F

Bounds on condition number

1219467.

$487 \quad 787$

Step 3 Variable TMSGSND Entered R-square $=0.62526937 \quad C(p)=$

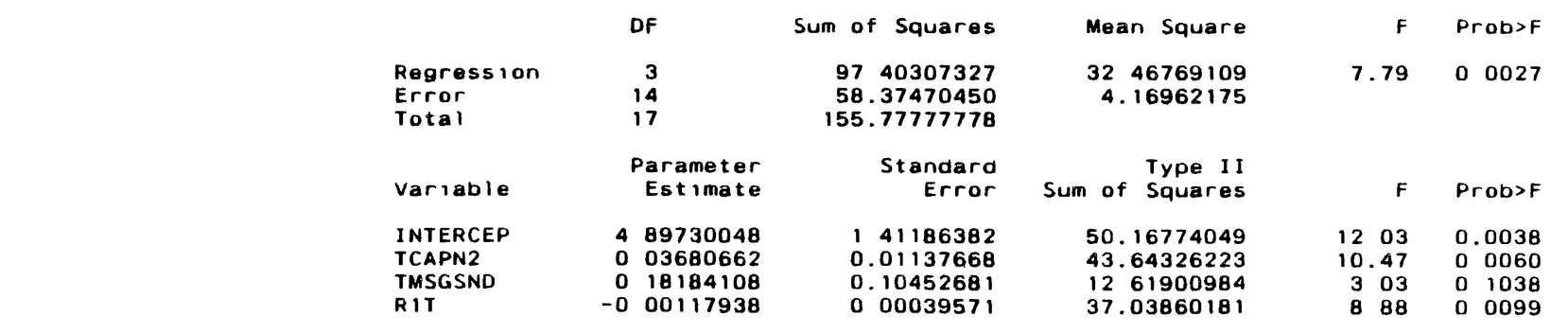

Bounas on condition number

1478584 .

864.4986 
Step 4 Variable TEXELNS Entered R-square $=0.63938286 \quad c(p)=$.

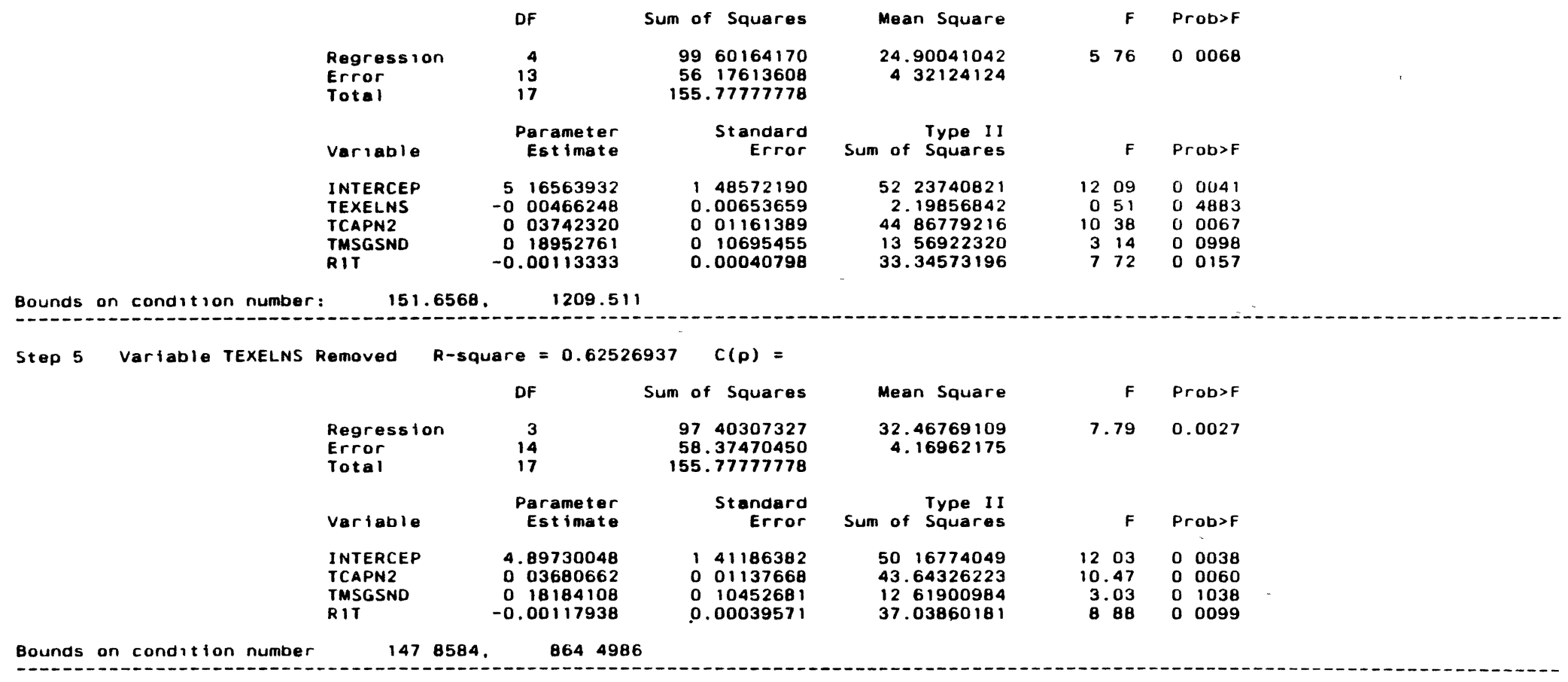

All variables left in the model are significant at the 01500 level.

No other variable met the 0.5000 significance level for entry into the model.

Summary of Stepwise Procedure for Dependent Variable 09.

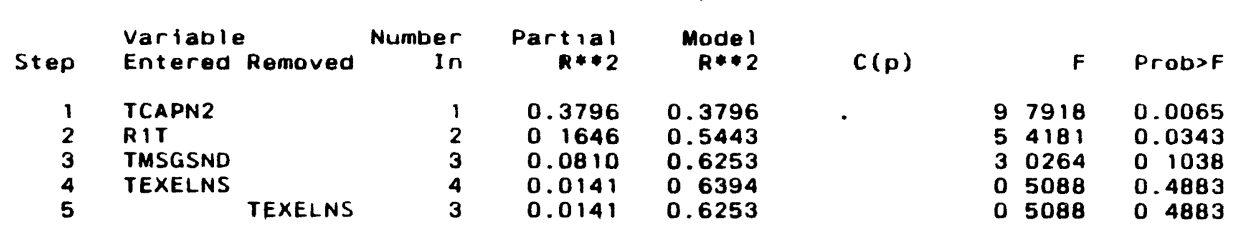




$\begin{array}{rcr}\text { Ods } & \begin{array}{c}\text { Dep Var } \\ \text { Q9 }\end{array} & \begin{array}{r}\text { Predict } \\ \text { Value }\end{array} \\ 1 & 5.0000 & 72188 \\ 2 & 50000 & 7.5775 \\ 2 & 10.0000 & 10.2305 \\ 3 & 100000 & 110368 \\ 4 & 10000 & 93768 \\ 5 & 100000 & 90.1089 \\ 6 & 100000 & 10.1089 \\ 7 & 100000 & 10.4952 \\ 8 & 100000 & 94897 \\ 9 & 10.0000 & 99294 \\ 10 & 10.0000 & 94419 \\ 11 & 100000 & 8.7063 \\ 12 & 150000 & 12.8355 \\ 13 & 15.0000 & 97669 \\ 14 & 130000 & 146600 \\ 15 & 130000 & 145062 \\ 16 & 14.0000 & 129162 \\ 17 & 16.0000 & 155720 \\ 18 & 100000 & 120916 \\ 18 & & \end{array}$

Sum of Restduals

Sum of Squared Residuals $\begin{array}{rrr}\text { Std Err Lower95\% } & \text { Upper95\% } \\ \text { Predict } & \text { Mean } & \text { Mean }\end{array}$

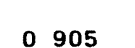

0905

0.907

0.916
0.692
1.774

1774

0.619
0.556

0.556
0.786

0.786

$\begin{array}{ll}0 & 732 \\ 0 & 855\end{array}$

0.736

0.839

0.839
1.109
1.095

1.095
0.796

0.796
1.576

1.576
0734

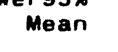

Mean

5.2771
5.6325
0.2651

9.5518

8.7803

$3028 \quad 116876$

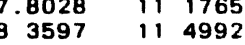

$6484 \quad 113153$

102846

$8.0208 \quad 11.5130$

$12.2812 \quad 170388$

121587

16.8536

12.1926
10.5164

$\begin{array}{ll}14 & 6229 \\ 18 & 9513\end{array}$

136667

\begin{abstract}
$\begin{array}{rr}58 & 3747 \\ 93 & 1659\end{array}$
\end{abstract}
\begin{tabular}{l} 
(Press) \\
\hline 3.1659
\end{tabular}
The SAS System

16:32 Saturday, May 25, 19913

Lwer95\% Upper95

$-2-1-0 \quad 12$

Cook's

$\begin{array}{lll}2.4281 & 12.0095 & -2 \\ 2.7858\end{array}$

$\begin{array}{lll}2.7855 & 12.3696 & -2.5775 \\ 6.4301 & 15.0308 & -02305\end{array}$

$6.4123 \quad 15.6612 \quad-02305$

$35748 \quad 15.1788 \quad 06232$

$\begin{array}{llll}55322 & 146855 & -0 & 1089\end{array}$

$\begin{array}{llll}5 & 9562 & 15.0342 & -0 \\ 4 & 7965 & 14 & 1852\end{array}$

$\begin{array}{llll}4.2770 & 141829 & 0 & 5103 \\ 5 & 5818 & 0 & 0706\end{array}$

$47340 \quad 14.2297 \quad 05181$

$\begin{array}{lll}4.0511 & 13.3616 & 12937\end{array}$

$\begin{array}{lll}50521 & 14.5704 & 2 \\ 5 & 1645\end{array}$

$\begin{array}{llll}9 & 6761 & 19.6439 & -16600\end{array}$

$\begin{array}{llll}95372 & 194752 & -1.5062\end{array}$

82158

17.6166

$-1.5062$

$\begin{array}{ll}7 & 4374\end{array}$

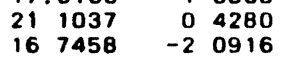

Residual Residual

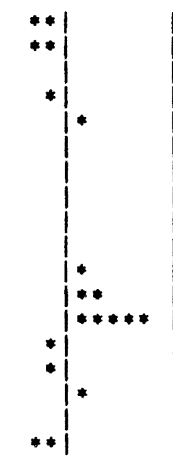

$0 \quad 090$

$\begin{array}{lll}0 & 122 \\ 0 & 001 \\ 0 & 009\end{array}$

$\begin{array}{lll}0 & 009 \\ 0 & 293\end{array}$

0000

$\begin{array}{lll}0 & 001 \\ 0 & 003 & 0\end{array}$

0000

0.004

0.069

$\begin{array}{lll}0 & 069 \\ 0 & 369 \\ 0 & 098\end{array}$

0.098
0.077

0.015
0.040

0.040
0.045 


\section{VITA \\ Imtiaz Ahmad \\ Candidate for the Degree of \\ Master of Science}

Thesis: SOFTWARE METRICS FOR PARALLEL PROGRAMS

Major Field: Computer Science

Biographical:

Personal Data: Born in Karachi, Pakistan, December 29, 1962, the youngest son of Mr. \& Mrs. K. M. Khan.

Education: Graduated from Federal Government Model School, Satellite Town, Rawalpindi, Pakistan, in June 1976; received Bachelor of Science degree in Mathematics from University of the Punjab, Lahore, Pakistan, in November 1981; completed requirements for the Master of Science degree at the Computer Science Department of Oklahoma State University in July 1991.

Professional Experience: Graduate Research Assistant, University Computer Center, Oklahoma State University, January 1989 to May 1991. 